\title{
RESPONSE TREES FOR DETECTION, DIAGNOSIS, AND TREATMENT OF EMERGENCY \\ CONDITIONS AT THE LOFT FACILITY
}

By

William R. Nelson

A thesis submitted in partial fulfillment of the requirements for the degree of

Master of Science in Nuclear Erigineering

University of Washington

1980

Approved by

Program Authorized

to Offer Degree

Date 


\section{DISCLAIMER}

This report was prepared as an account of work sponsored by an agency of the United States Government. Neither the United States Government nor any agency Thereof, nor any of their employees, makes any warranty, express or implied, or assumes any legal liability or responsibility for the accuracy, completeness, or usefulness of any information, apparatus, product, or process disclosed, or represents that its use would not infringe privately owned rights. Reference herein to any specific commercial product, process, or service by trade name, trademark, manufacturer, or otherwise does not necessarily constitute or imply its endorsement, recommendation, or favoring by the United States Government or any agency thereof. The views and opinions of authors expressed herein do not necessarily state or reflect those of the United States Government or any agency thereof. 


\section{DISCLAIMER}

Portions of this document may be illegible in electronic image products. Images are produced from the best available original document. 
In presenting this thesis in partial fulfillment of the requirements for a Master's degree at the University of Washington, I agree that the Library shall make its copies freely available for inspection. I further agree that extensive copying of this thesis is allowable only for scholarly purposes. It is understood, however, that any copying or publication of this thesis for commercial purposes, or for financial gain, shall not be allowed without my written permission.

Signature $=\ldots \ldots \ldots \ldots \ldots \ldots \ldots$

Date 
University of Washington

\author{
Abstract \\ RESPONSE TREES FOR DETECTION, DIAGNOSIS, \\ AND TREATMENT OF EMERGENCY \\ CONDITIONS AT THE LOFT FACILITY \\ By William R. Nelson
}

Chairperson of the Supervisory Committee: Dr. A. L. Babb

Department of Nuclear Engineering.

A technique for detecting, diagno'sing, and treating emergency conditions has been developed at the LOFT facility. A response tree is a pictorial representation of many different cooling modes which can be used to $\mathrm{cool}$ the reactor core. A comprehensive methodology is being developed which will assist the reactor operator in choosing the correct cooling mode, monitoring its performance, and selecting an alternate mode when required. The technique will be implemented using a computer to monitor system status and evaluate the response trees. 


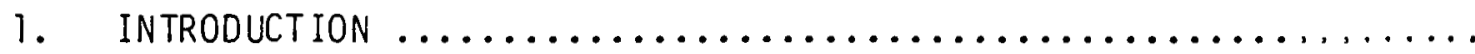

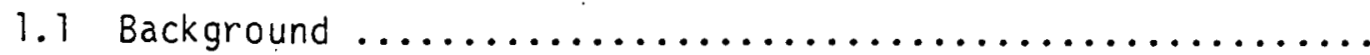

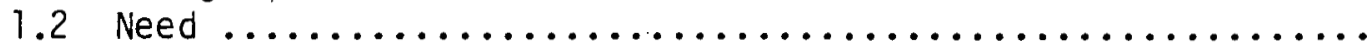

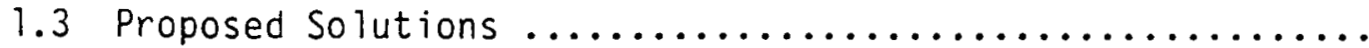

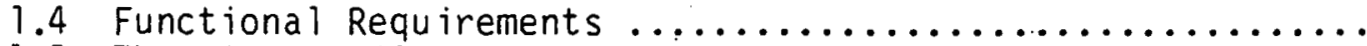

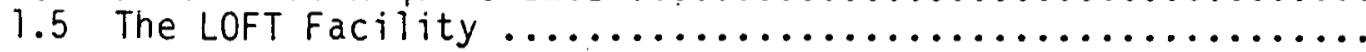

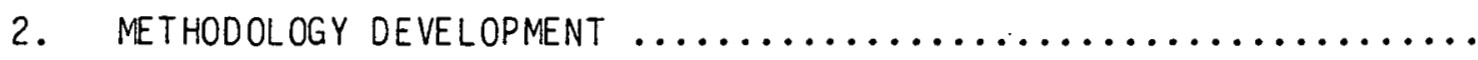

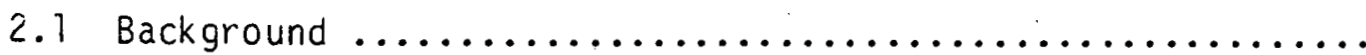

2.2 Description of Response Tree Methodology $\ldots \ldots \ldots \ldots \ldots . .$.

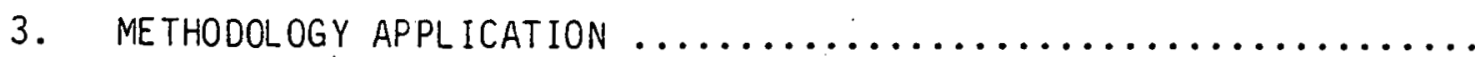

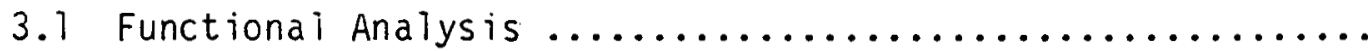

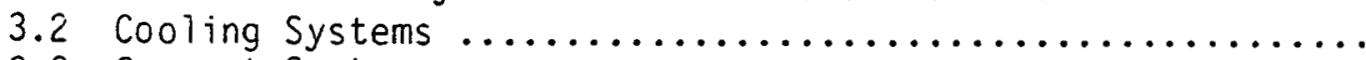

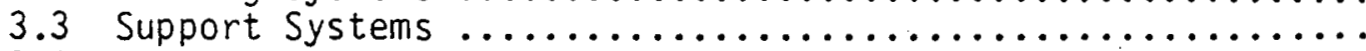

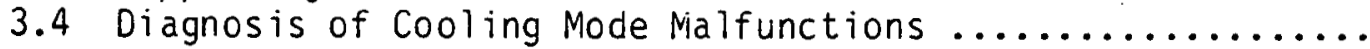

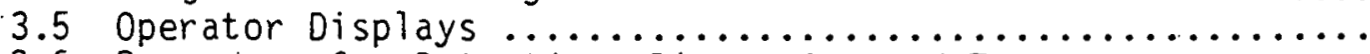

3.6 Procedure for Detection, Diagnosis, and Treatment

of Emergency Conditions

4. METHODOLOGY DEMONSTRATION

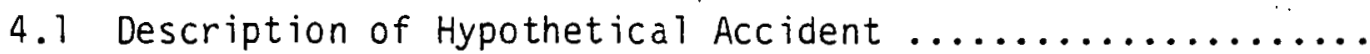

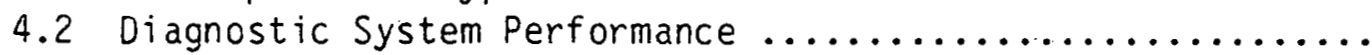

5. CONCLUSIONS

6. REFERENCES

APPENDIX A: Definition of Terms

APPENDIX $\bar{B}$ : Symbols and Acronyms

APPENDIX C: Component Attribute Tables

APPENDIX D: Component Level Response Trees

APPENDIX E: Cooling Mode Instrumentation 


\section{FIGURES}

1. Elements of a cooling mode

2. Closed loop cooling mode

3. Open loop cooling mode

4. Simplified schematic of LOFT Low Pressure Injection System (LPIS)

5. LOFT LPIS response tree

6. Choice of cooling mode for example accident

7. Operation profile: emergency recovery and decay heat removal

8. Flow diagram: emergency recovery and decay heat removal

9. LOFT primary coolant system

10. Injection points and reactor vessel regions

11. Response tree for primary, secondary, purification, high

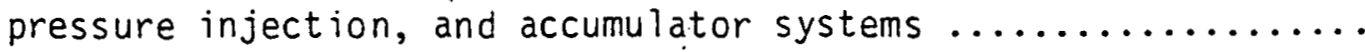

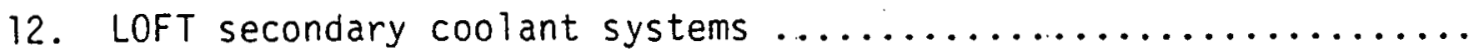

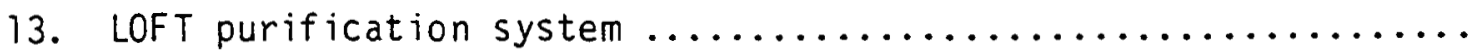

14. LOFT high pressure injection and accumulator systems $\ldots \ldots \ldots$

15. LOFT low pressure injection system

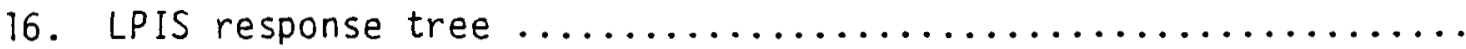

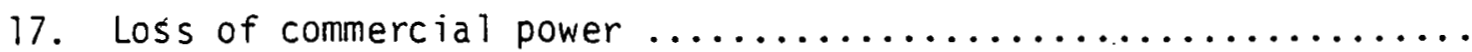

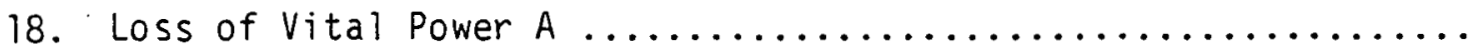

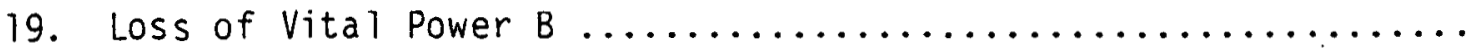

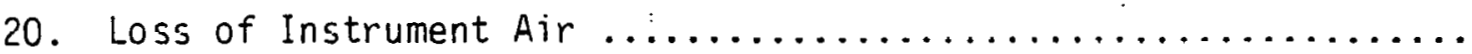

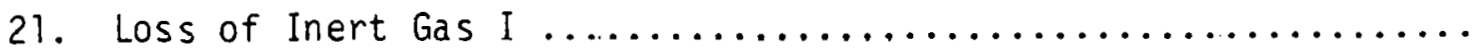

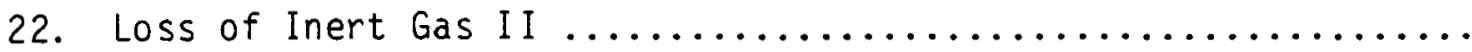


23. Loss of service water

24. System schematic display

25. Response tree display

26. Display for diagnosis of component failures

27. Procedure for detection, diagnosis, and treatment of emergency conditions

28. Phase 1 diagnostic table

29. Phase 1 response tree

30. Phase 1 schematic

31. Phase 2 diagnostic table

32. Phase 2 response tree

33. Phase 2 schematic

34. Phase 3 diagnostic table

35. Phase 3 response tree

36. Phase 3 schematic

37. Phase 4 diagnostic table

38. Phase 4 response tree

39. Phase 4 schematic

40. Phase 5 diagnostic tabie

41. Phase b responsc Erec

42. Phase 5 schematic

43. Phase 6 diagnostic table

44. Phase 6 response tree.

45. Phase 6 schematic

46. Phase 7 diagnostic table 
47. Phase 7 response tree

48. Phase 7 schematic

49. Phase 8 diagnostic table

50. Phase 8 response tree

51. Phase 8 schematic 


\section{TABLES}

1. Diagnosis of Component Status

2. Diagnosis of Reactor Vesse 1 Status

3. Diagnosis of Cooling Mode Status 
The author wishes to express his sincere appreciation to Dr. A. L. Babb for his suggestions and encouragement during the formulation and performance of this project. Special gratitude is expressed to Orville Meyer for his suggestions and support of this project as a portion of the LOFT Augmented Operator Capability Program. Jim Close, Dale Rasmuson, and Jim Shepherd offered many helpful suggestions during the development of the response tree methodology. Mike Clark contributed much useful information concerning the needs of the nuclear reactor operator. Finally, special affection and gratitude is expressed to my wife, Laurie, without whose patience and faith this project would never have been completed.

This report was prepared as an account of work sponsored by an agency of the United States Government. Neither the United States Government nor any agency thereof, or any of their employees; makes any warranty, expressed or implied, or assumes any legal liability or responsibility for any third party's use, or the results of such use, of any information, apparatus, product or process disctosed in this report, or represents that its use by such third party would not infringe privately owned rights. The views expressed in this paper are not necessarily those of the U.S. Nuclear Regulatory Commission.

Work supported by the U.S. Nuclear Regulatory Commission, Office of Nuclear Regulatory Research under DOE Contract No. DE-ACO7-76ID01570. 


\section{INTRODUCTION}

\subsection{Background}

The nuclear reactor operator has been placed in a difficult situation in recent months. After many years of relative obscurity as the custodian of a showplace technology, he has suddenly been thrust into the glaring light of public and industry scrutiny. He is being asked to explain why he is not always capable of effectively responding to reactor accidents. This situation has not developed overnight, but is rather a combination of recent events and long term developments from the past.

When the nuclear power industry was in its infancy, responsibile engineers correctly identified the stringent need for effective control of the new technology to protect the health and safety of the public. To 1 imit the consequences of events which could harm the public, the concepts of multiple barriers, redundancy and diversity of safety systems, and automatic plant protection systems were developed. To quantify the probability of such events, the discipline of reliability engineering and its tools: such as fault and event trees were utilized.

Analytic efforts focused on identifying and evaluating specific accident sequences representing catastrophic "worst case" scenarios. The underlying (and usually unstated) assumption was that if the system could withstand these pvents. it could also withstand the entire range of accidents. Safety systems were designed using this assumption.

Following such a design process, the operator's role was established. The operator was given those tasks not already given to automated safety systems. The operat.nr was therefore given the role as a monitor of the safety systems rather than as a vital component of the safety systems. 
Naturally, the operator's training emphasized the role he had been given by the system designer. The operator was trained to operate the reactor under normal conditions, and to monitor safety systems 'in case of an accident. He was not trained to fully understand the underlying processes of the system so that he could take charge if the system did not function as expected.

The design of the main control room also reflects the limited safety functions allocated to the operator. All the information deemed important by the system designer is presented, but in a fragmented pattern which does not encourage an understanding of overall system operation. There is little discrimination between important information and that which is of little interest. Indicators and controls are not designed to optimize the operator's monitoring and action functions.

Improvements on the system design discussed above are not encouraged by the regulatory process. Once a design has been approved and licensed, there is little incentive for innovations which could result in lengthy licensing. hearings and public comment.

The previous history of the nuclear power industry has thus left the facility operator in a vulnerable position, unable to effectively cope with situations beyond that for which he was trained. The Three Mile Island incident served to throw the spotlight on his situation. The operator is the unfortunate victim of the philosophies and design processes of the entire nuclear industry. A failure to remedy this situation could result in the demise of nuclear power as a viable energy supplier.

Prior to the Three Mile Island incident, little attention was given to the role of the nuclear reactor operator as a vital component of the entire system. However, the aerospace and military industries had recogrized the need to incorporate the human operator in the overall design of the system. The field of human factors engineering ' had its beginnings during world War II as problems arose in new technologies such as radar and high speed 
aircraft. The greatest share of research of human factors engineering was devoted to the operator's physical surroundings and how he reacted with them through his senses. 2 Because of the lack of space in the aircraft cockpit and the speed at which it was flying, great emphasis was given to the arrangement of controls and instruments and the design of displays to present information rapidly and accurately.

As the systems being designed grew more complex and presented greater challenges to the operator, attention began to shift to the information processing and decision-making roles of the operator. ${ }^{3}$ The techniques of functional analysis and task analysis were developed to determine the performance requirements $p$ laced on the human operator and the needs which must be met in order for him to perform satisfactorily. (References 2 and 3). Functional and task analyses were particularly useful in determining the information needs of the operator for making critical decisions. New training programs and methods were instituted to enable the operator to perform adequately under field conditions.

The information gathered in the development of human factors engineering has been incorporated in various handbooks and military standards. 4,5 However, such handbooks tend to be general in nature and difficult to apply in many situations. The need to include a strong human factors engineering effort in the design of complex systems is still great.

Unfortunately, the lessons learned in the aerospace and military industries were almost entirely neglected in the development of control stations for nuclear reactor facilities. Studies of the human operator in the pre-TMI era tended to emphasize three areas: the physical layout of the control room ${ }^{6}$, mathematical models of the reactor operator ${ }^{7}$, and studies of the operator's "failure rate" for reliability studies. 8 Most of these studies were of a theoretical nature and were not implemented in the design of nuclear systems. Design requirements for nuclear facilities paid lip service 
to the need for human factors considerations with statements such as "... systems shall be designed using human engineering principles to permit reliable and safe operation...." However, qualified human factors engineers were usually not available to implement such requirements.

The Nuclear Regulatory Commission and its predecessors acknowledged the presence of the operator by issuing Regulatory Guides $9,10,11$ governing his conduct and the design of instrumentation systems for assisting him. The intent of these guides was honorable, but definite guidelines on how to effectively implement them were lacking.

Even before TMI, however, a few persons recognized the need for improved methods of gathering and interpreting data, and for presentation of relevant information to the operator to assist him in crisis situations. Denning, Miller, and Plummer ${ }^{12}$ investigated the operator's information needs for a wide range of potential accidents in light water reactors. Gonzalez and Howington 13 investigated concepts for pattern recognition of noise signals to detect abnormal conditions in nuclear reactors. The Nuclear Regulatory Commission ${ }^{14}$ recognized improved in-plant accident response, including improved monitoring and accident diagnostic systems, as a worthwhile topic for increased research. Unfortunately, this recognition did not occur in time to prevent the accident at Three Mile Island.

\subsection{Need}

In the months following the accident at Three Mile Island, a blizzard of studies was generated, all commenting on the causes of the accident and recommending changes to prevent further such incidents. $15-20$ The NRC attributed the severity of the consequences of the accident to operator error (Reference 15). However, other studies looked into the incident in more depth and noted deficiencies in control room and instrumentation design, inadequate procedures, incomplete operator training, and the lack of a logical system for processing data to present meaningful information to the operator. 
Many recommendations were made to address the deficiencies which were noted. Many emphasize the physical aspects of control room design, 21, 22 especially the design and placement of important instruments and controls. Others emphasize the need for improved operator training and improved procedures. Most recommend the development of improved methods for selecting, processing, and displaying relevant information to the operator to allow him to more efficiently cope with abnormal situations. "Equipment should be reviewed from the point of view of providing information to operators to help them prevent accidents and to cope with accidents when they occur." (Reference 16). "Additional diagnostic operational aids, such as logic trees or disturbance analyzers, should be required in all control rooms." (Reference 20)

The most crucial shortcoming of the Three Mile Island facility was not the physical design of the control room or the training of the operators. The required data was available and their training was adequate to diagnose the situation, but the information required to make a quick and confident diagnosis was not present in a usable form. The operators were overwhelmed with data concerning the status of the facility, but what they needed most was information which would allow them to understand the situation and respond appropriately.

Nuclear reactor facilities greatly need an information system which can process the available data and present meaningful. information to the operator so that he can effectively detect abnormalities and correct them before serlous consequences result. This thesis was undertaken to bcgin the development of such a system.

\subsection{Proposed.Solutions}

A number of methods are being developed to provide the reactor operator with relevant information during accident situations. A relatively simple system is being developed which recommends a procedure to follow based on 
an analysis of the annunciators which have alarmed. 23 This system is limited because it cannot detect incidents before they are serious enough to produce alarms, and only those parameters which are annunciated can be included.

A. number of methods are being developed which utilize fault trees, event trees, or cause-consequence diagrams to enumerate potential accident sequences. 24,25 These techniques require the analyst to predetermine the events which could jeopardize safe operation, determine the appropriate symptoms, and determine the correct response for each. A logic model containing the accident sequences, symptoms, and responses is programmed into the plant monitoring computer. When the computer detects the presence of one of the accident sequences, the operator is alerted and an appropriate response is recommended. These techniques share the fault that although their logic models are very complex, important accident sequences may be neglected.

Other techniques are being developed which monitor "characteristic parameters" which indicate whether or not the facility is operating correctly. Deviations from the normal values of these parameters are evaluated for their significance and an appropriate response is recommended. These techniques do not require the predetermination of all potential accident sequences. The event is analyzed for significance as it occurs and is compared with generic groups of events having similar symptoms. However, al though the event is identified with a generic class of accidents based on its symptoms, a specific response can be recommended based on its specific symptoms. This greatly simplifies the logic model used for acciuent diagnosis. An important element of these techniques is an accurate logic model of facility systems which describes the operation of the systems and the interactions between systems. Examples of the "characteristic parameter" approach are the safety function methodology 26 and the response tree technique. 27 The response tree methodology was chosen for further development in this thesis. The technique has been refined and expanded to provided a more comprehensive system for processing and presenting relevant information to the reactor operator during emergency conditions. Details are presented in Sections 2 and 3 . 


\subsection{Functional-Requirements}

In order to provide meaningful assistance to the reactor operator, any information processing or disturbance analysis system should meet certain functional requirements. The system should represent a significant advancement over currently available diagnostic systems. It shouid include a set of meaningful "characteristic parameters" by which the status of the system can be monitored. It should be capable of determining the overall condition of the plant based on the available symptoms and recommending an appropriate response when conditions warrant. If the response does not bring about the desired status improvement, the system should be capable of recommending a contingency action. A means should be provided for presenting unambiguous information to the operator concerning current facility status and recommended courses of action.

To ease implementation in current and future control rooms, such an information system should be capable of implementation without excessive modification to control room design. In addition, to be relied on as an operator aid for emergency situations, the system will have to meet all the qualifications of a safety related system, including all requirements for redundancy and reliability. Finally, any such information system must in reality present the operator with correct information without confusing him and making matters worse than before.

\subsection{The LOFT-Facility}

The Loss of Fluid Test (LOFT) facility is located at the Idaho National Engineering Laboratory near Idaho Falls, Idaho. The LOFT program is designed to test the response of an operating nuclear reactor and associated safety systems to actual emergency conditions. The LOFT reactor is a $50 \mathrm{MW}(\mathrm{th})$ reactor which models a large pressurized water reactor (LPWR). LOFT has one active primary coolant loop which models three of the primary loops of an LPWR. The fourth loop of the LPWR is represented at LOFT by a blowdown loop. 
The blowdown loop contains two Quick Opening Blowdown Valves (QOBVS) which can be opened to initiate a Loss-of-Coolant Experiment (LOCE) which represents the conditinns which would be experienced during a loss-of-coolant accident (LOCA) in an LPWR.

Early experiments at LOFT (beginning in 1976) modeled the complete rupture of a large primary coolant. pipe. Although very important from an analytic and licensing point of view, such a catastrophic event has a very low probability of occurrence. The early tests of the LI and L2 series increased confidence that Emergency Core Cooling Systems (ECCS) were adequately designed to mitigate the consequences of a large LOCA.

Following the accident at Three Mile Island in March 1979, the nuclear community awoke to the realization that large break accidents were not necessarily those which would have the worst consequences. More probable, slower developing event sequences have a much greater potential for confusing the operator and thereby potentially represent a more serious risk. Accordingly, the LOFT schedule was rearranged to expedite the investigation of these types of events. The small break or $L 3$ test series, which tests the response of the facility and its operator to a small loss of coolant accident (similar to that at TMI), was begun in 1979. A series of Operational Transient (L6 series) experiments was initiated in 1980. Operational transient events are accidents (such as loss of feedwater flow) which are not loss of coolant accidents but nonetheless may result in adverse consequences if not mitigated effectively.

With the redirection of the LOFT program have come increased opportunities to investigate the operator's role in the operation of a nuclear facility. The L3 and L6 experiments place significant demands on the operator to carefully monitor the status of the facility and respond appropriately when required. LOFT is particularly suitable. for investigating the man-machine interface because of its capabilities to produce accident conditions in a realistic environment. 
Studies undertaken at LOFT are relevant to commercial reactors Decause of the great similarities between LOFT and commercial facilities. As mentioned previously, LOFT was designed to model a large commercial reactor. Its primary and secondary coolant systems are functionally very similar to those on commercial facilities, as is the Emergency Core Cooling System (ECCS). Electrical power systems, pneumatic systems, water supply systems, and plant protection logic are all comparable to those of commercial pressurized water reactors.

Of particular importance to the study of the man-machine interface are the numan aspects of the LOFT facility. The training, experience, and composition of the operating crew are quite comparable to those at a commercial facility. The administrative controls placed on facility operation, especially the Technical Specification and the Plant Operating Manual (POM), have been patterned after those of commercial reactors.

To take advantage of the qualifications of the LOFT facility as a laboratory for studies of the man-macnine interface, the LOFT Augmented Operator Capability (AOC) program was initiated in late 1979. This program will be investigating and testing new ideas for improving the effectiveness of the man-machine interface in nuclear reactor facilities. This thesis was performed to investigate the potential for incorporating the response tree metnodology into the LOFT AOC program. 


\section{METHODOLOGY}

\subsection{Background}

The work which led to the development of the response tree methodology was begun in $1977 .{ }^{28}$ At that time a pipe rupture and missile nazards evaluation was performed at the LOFT facility. To, reduce the risk associated with postulated pipe ruptures and missiles, a number of emergency procedures were written for responding to a wide range of such incidents. However, an important question arose: How would the reactor operator know when to use the procedures, and how would he know which procedure to use? Response trees were developed to provide the link between a list of very specific accident sequences and a set of generic emergency procedures. By using the response trees, the operator could monitor system status, differentiate between different accident sequences, and select the correct procedures. As a bonus, the response trees were capable of nanding not only pipe rupture and missile accidents, but any events which disable components used to cool the reactor core.

Early in 1978 response trees were developed for the LOFT Emergency Core Cooling System (ECCS) and placed in the Plant Operating Manual (POM). At that time use of the response trees was strictly manual, requiring the operator to manually gather the required data and evaluate the response trees. After the accident at Three Mile Island, plans were begun to expand the response tree metnodology so it could be used as an on-line system for operator assistance. This thes is reports the first phases of this effort.

\subsection{Methodology Description}

One of the most important functions which must be performed to prevent the release of radioactive materials from reactor fuel is to keep the fuel elements cool. Under most circumstances, this is done by forcing water through the reactor vessel, between the fuel rods, and out of the reactor 
vessel to a heat sink. In a pressurized water reactor, the water is kept from boiling by keeping the water at a pressure above the saturation pressure. This is accomplished by heating water in the pressurizer to maintain pressure sufficient to prevent boiling in the reactor vessel.

Nuclear reactor facilities have more than one system jesigned to remove heat from the fuel elements. During normal operation at LOFT, the primary and secondary coolant systems function together to remove heat from the reactor fuel. Other systems, such as the Auxiliary Feedwater System, the Purification System, and the Emergency Core Cooling System, can be used to cool the reactor during other modes of operation.

For purposes of discussion, each minimum set of components used to cool the core can be called a cooling mode. In most cases, a cooling mode will consist of five elements: a heat sink, a water source, a pump, a route, and an injection point. The heat sink is the fluid or location where the heat which has been removed from the fuel is ejected from the system. The water source is the tank or vessel which holds the cooling water used by the cooling mode. The pump removes the water from the water source and drives it towards the primary coolant system. The route is the piping by which the water is carried. The injection point is the location at which the water is finally delivered to the primary coolant system. The elements of a cooling mode can be arranged as shown in Figure 1. As can be seen from the figure, the cooling mode can also be assigned an identifying number (which can be used to denote relative priority of use) and the procedure which is used to implement the cooling mode.

A response tree is simply a pictorial representation of a number of different cooling modes. Where possible, common elements of different cooling modes are joined together near the top of the tree to show the interconnections between cooling modes. At the bottom of the tree, however, it is often necessary to separate common elements to preserve the boundaries 


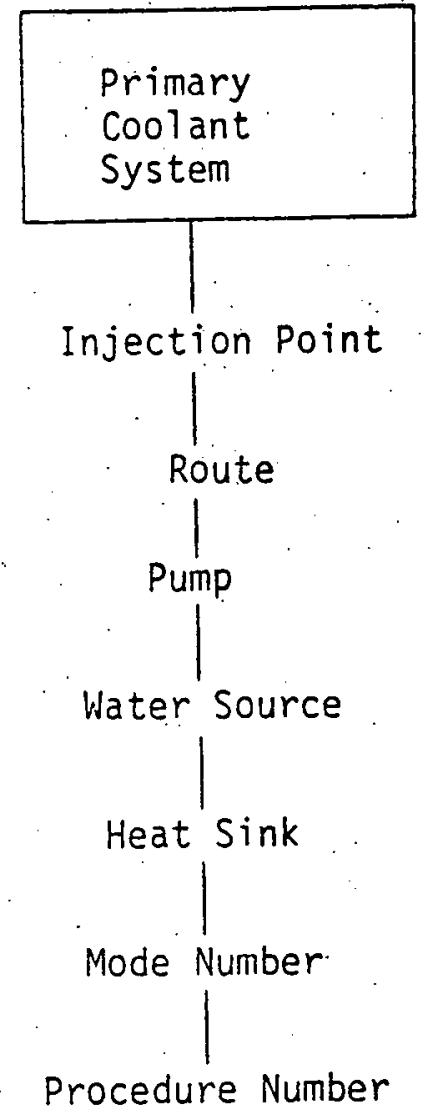

Figure 1. Elements of a cooling mode 
of distinct cooling modes. In this sense, the response tree is a variation of the system schematic (or its reliability block diagram) which has been separated at the lower levels so that each distinct cooling mode is displayed separately.

Except for the heat sink, the elements of the cooling mode have been arranged according to the ir normal physical order. The heat sink has been placed at the bottom of the tree for convenience, since the physical location is quite variable. For example, a closed loop cooling mode (Figure 2) normaliy uses an active heat exchanger to which the heat from the reactor fuel is ejected. An open loop cooling mode (Figure 3) on the other hand, uses cold water to remove heat from the reactor fuel. The heated water then gives up the heat to the containment atmosphere. Some facilities require another cooling system to remove the heat from the containment atmosphere, although LOFT does not.

Figure 4 is a simplified schematic of the LOFT Low Pressure Injection System (LPIS), and Figure 5 is the response tree for the LPIS. Note how the various cooling modes of the response tree relate to the arrangement of the components on the schematic. Not all component combinations are represented on the response tree because some combinations are not effective for removing heat from the reactor core.

Mode numbers are assigned based on their relative desirability of use. Cooling modes with low mode numbers are to be used before modes which have higher mode numbers. Cooling modes with equal numbers (such as $24 A$ and $24 B$ ) may be used concurrently if desired. These numbers are assigned based on the effectiveness of the cooling mode, the ease of its implementation, and other similar considerations. As mentioned previously, each cooling mode is also assigned the numbers of the procedures used to implement the cooling mode.

Each element of a cooling mode typically consists of a number of individual components. For example, an injection point consists of piping, various valves in the piping, and valves which maintain the integrity of the 


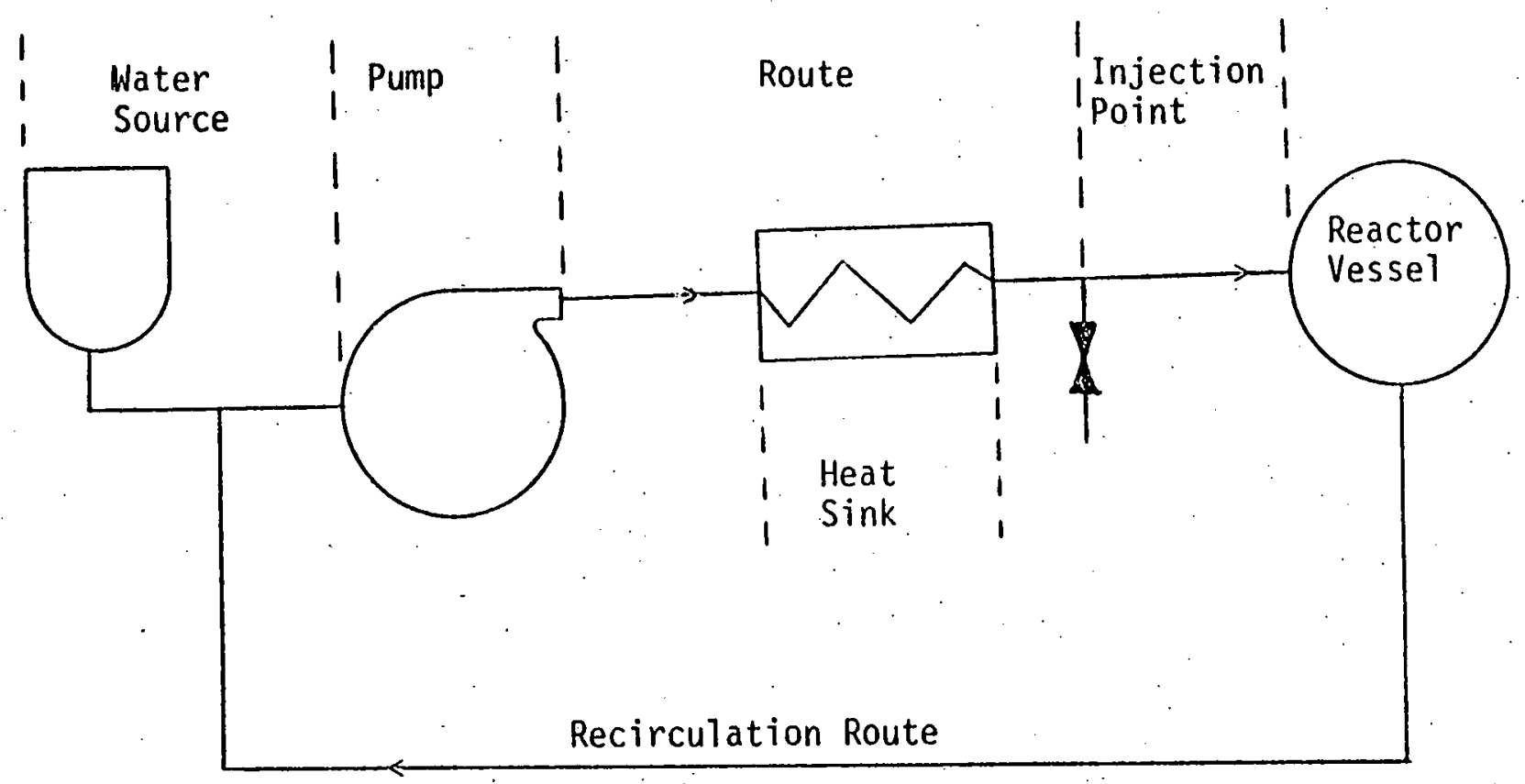

Figure 2. Closed 10op cooling mode 


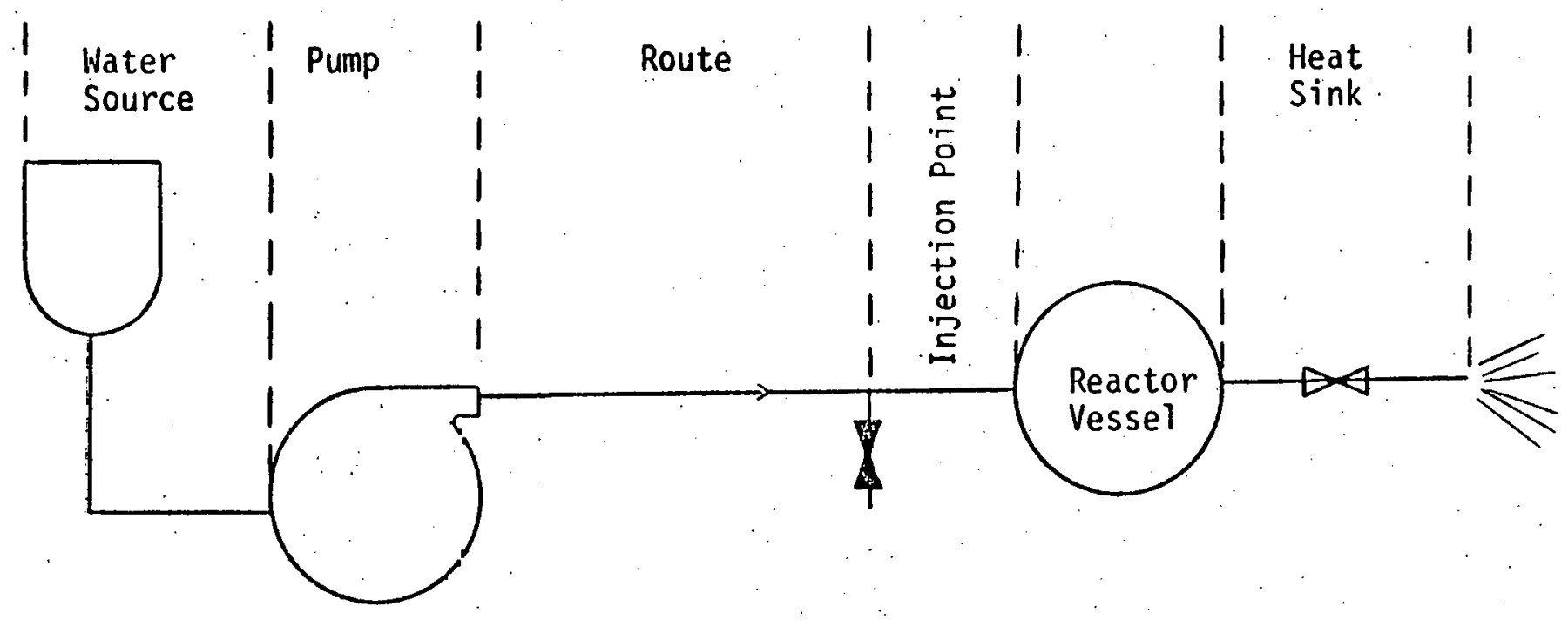

Figure 3. Open loop cooling mode 
Figure 4. Simplified schematic of LOFT Low Pressure Injection System (LPIS)

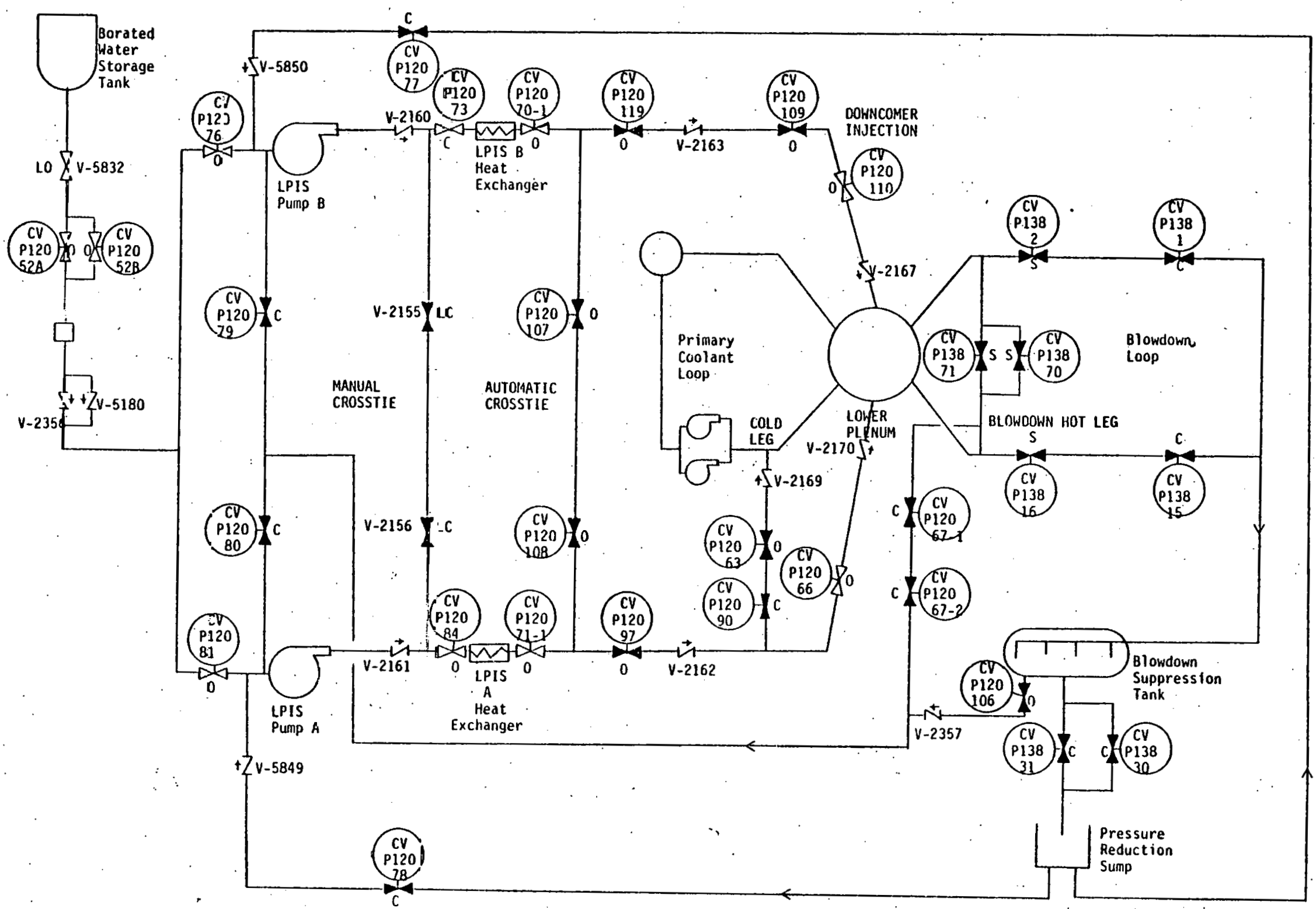


Figure 5. LOFT LPIS response tree

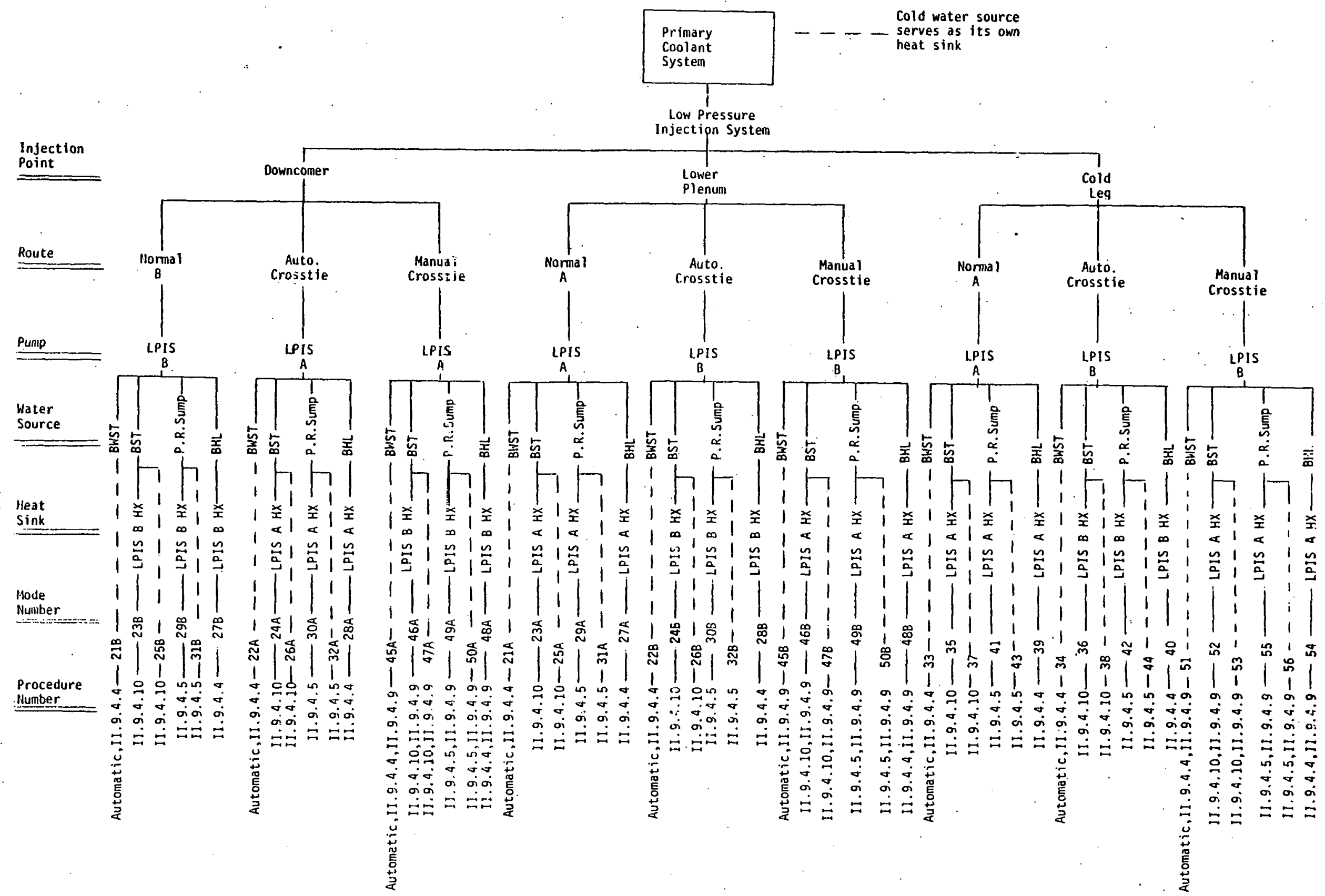


injection point. Heat sinks, water sources, and pumps may include valves which are in the piping connecting them to other elements of the cooling mode. For demonstration purposes, the response trees used in this report will show the cooling mode elements only, not the individual components. Complete response trees showing the individual components are contained in Appendix $D$.

During normal operation, the LOFT reactor is cooled using the primary and secondary coolant systems. The primary coolant pumps force water through the reactor core to the steam generator, where the heat is transferred to the secondary system. On the secondary side of the steam generator, secondary water is turned to steam and then flows to the air cooled condenser. Here the steam is condensed and the heat is given up to the outside atmosphere.

When an accident occurs, it may be necessary to shift to another cooling mode to cool the reactor, especially if certain cooling mode components are disabled. When a component is disabled, any cooling mode which utilizes it cannot be used for reactor cooling, and another mode must be selected. The mode selected next is the one with the lowest mode number which is still available. The operator will then refer to the procedure associated with that cooling mode and perform the prescribed actions. For example, consider a situation in which the Low Pressure Injection System is being used to cool the reactor. Then, assume that 1) LPIS pump A fails to start, 2) a pressure indicator in the downcomer injection line indicates that flow is not reaching the reactor vesse 1, and 3) the Borated Water Storage Tank (BWST) is empty. The r.nnling mode with mode number $24 B$ is chosen based on an evaluation of the response tree. Figure 6 shows conceptually how the response tree will be evaluated by the computer. Components known to be disabled or unavailable for use are crossed out. All mode numbers of cooling modes which utilize unavailable components are also crossed out. Finally, the cooling mode with the lowest number which remains available is selected for use, assuming it is appropriate for current plant conditions. The operator is then advised to implement this procedure. Thus, in this example, the operator refers to procedure II. 9.4.10 and implements the chosen cooling mode. As time progresses and other components are disabled or restored, the response tree is continualiy updated to ensure that the optimum cooling mode is being implemented. 
Figure:6. Choice of cooling mode for example accident

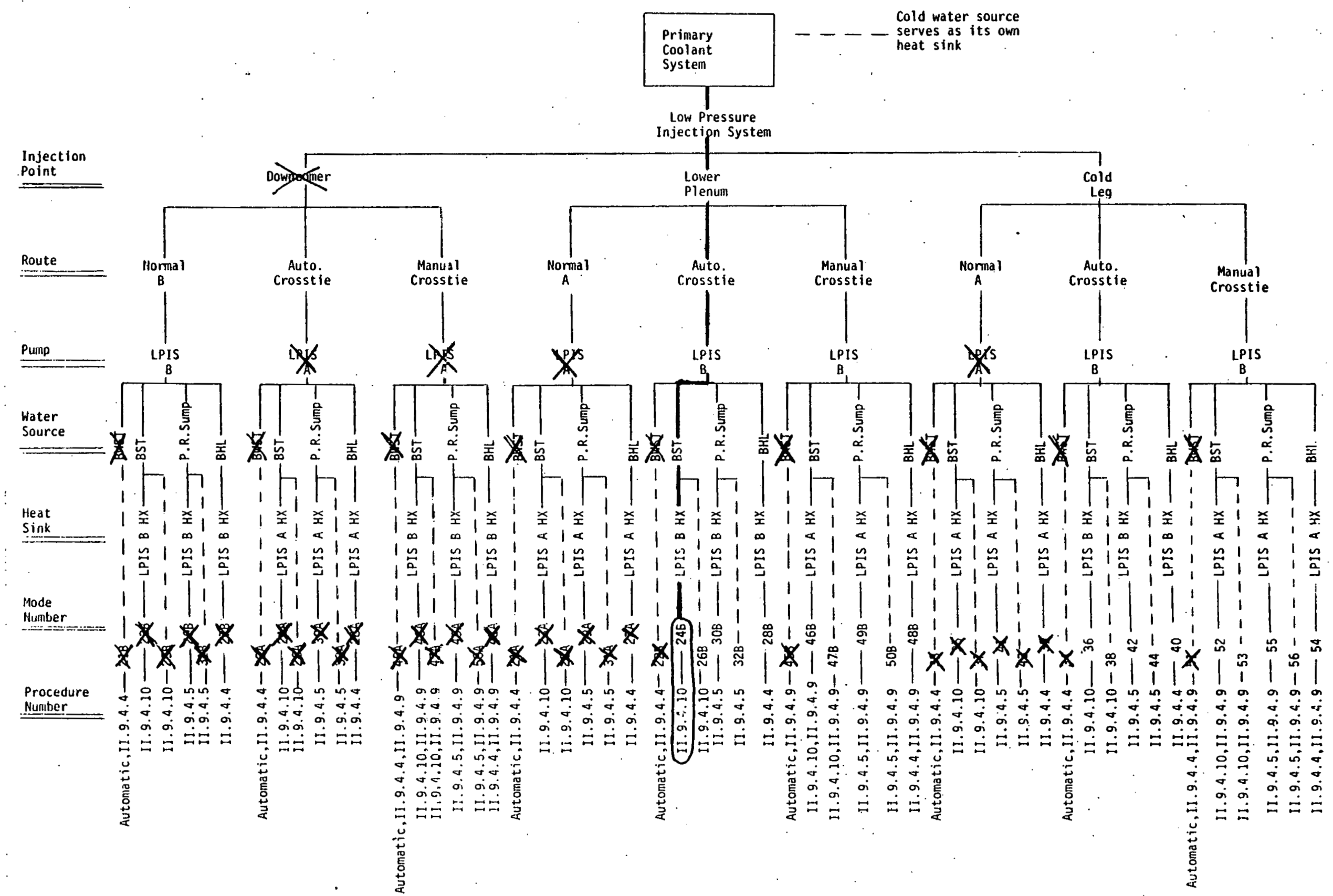


Many extensions and improvements have been added to the resporise tree methodology since its original development. These additions will be discussed in detail in Section 3 . 


\section{METHODOLOGY APPLICATION}

\subsection{Functional. Anatysis}

A simple functional analysis was performed for the detection, diagnosis, and treatment of an accident situation at LOFT. This was done to determine the operator's information needs during such a sequence of events. First, the sequence was decomposed into discrete stages using an operational profile (Figure 7). An accident has been assumed which requires detection and control of the initial disturbance, and is sufficiently serious so that decay heat removal is required to bring the facility to a cold shutdown condition. The shape of the curve is used merely to conceptualize the stages of the accident. Figure 8 is a flow diagram illustrating the sequence of events and operator decisions required in this detect-diagnose-treat sequence.

Note that the operator is called on to perform five information processing tasks.

1. He must determine the plant status from the available symptoms. That is, he must diagnose the event.

2. He must determine an appropriate response.

3. He must evaluate the effectiveness of the response.

4. He must select a decay heat removal (UHK) mode.

5. He must evaluate the effectiveness of the OHR mode.

Response trees will he used to assist the operator in performing these tasks. Detailed response trees for the LOFT facility are presented in Section 3.2 , and a detailed procedure for using the response trees for the control of an accident sequence is presented in Section 3.6 . 


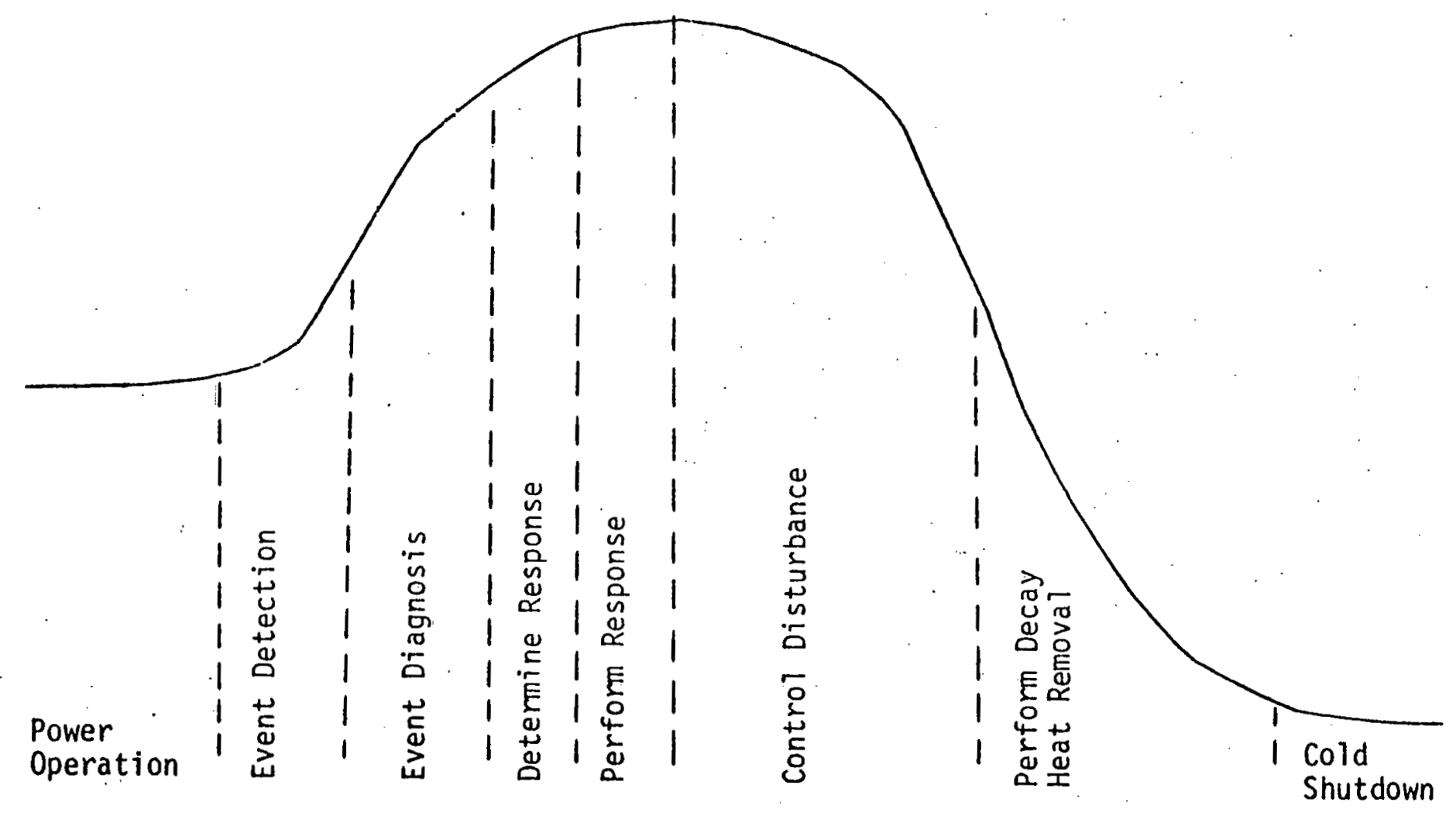

Figure 7. Operation profile: emergency recovery and decay heat removal 


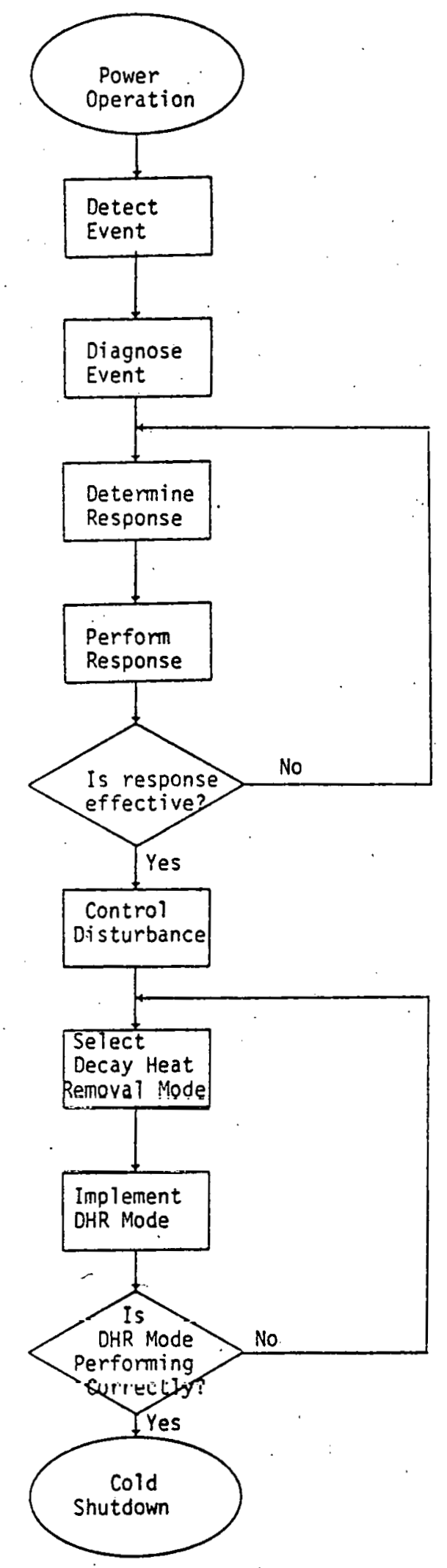

Figure 8. Flow diagram: emergency recovery and decay heat removal 


\subsection{Eooling Systems}

Four major systems can be used for cooling the LOFT reactor during normal and emergency conditions: the primary coolant system, secondary coolant system, the purification system, and the emergency core cooling system (ECCS).

\subsubsection{Primary-Coolant System.}

The Primary Coolant System is used to cool the reactor core during normal power operation of the LOFT facility. Two primary coolant pumps force cooling water into the reactor vessel downcomer, into the lower. plenum, and through the reactor core. The heated water leaves the reactor vessel from the upper plenum and flows to the steam generator. In the steam generator the primary coolant gives up heat through the steam generator tubes to the secondary coolant. The cooled water then returns to the suction inlets of the primary coolant pumps.

Primary coolant pressure is maintained by the pressurizer, which is heated by electrical heaters. "Overpressure protection is provided by two safety relief valves and the power operated relief valve.

Figures 9 and 10 show the arrangement of the LOFT primary coolant system. Figure 11 shows the response tree for the primary coolant system.

\subsubsection{Secondary. fnn}

The Secondary Coolant System is used to remove heat from the primary coolant system during normal and emergency conditions. The main feedwater pump takes suction from the condensate receiver through the subcooler. The secondary water is forced into the shell side of the steam generator where it is turned to steam. The steam then flows through the steam flow control valve to the air cooled condenser where it condenses back into water. From the air cooled condenser the water flows into the condensate receiver once again. 


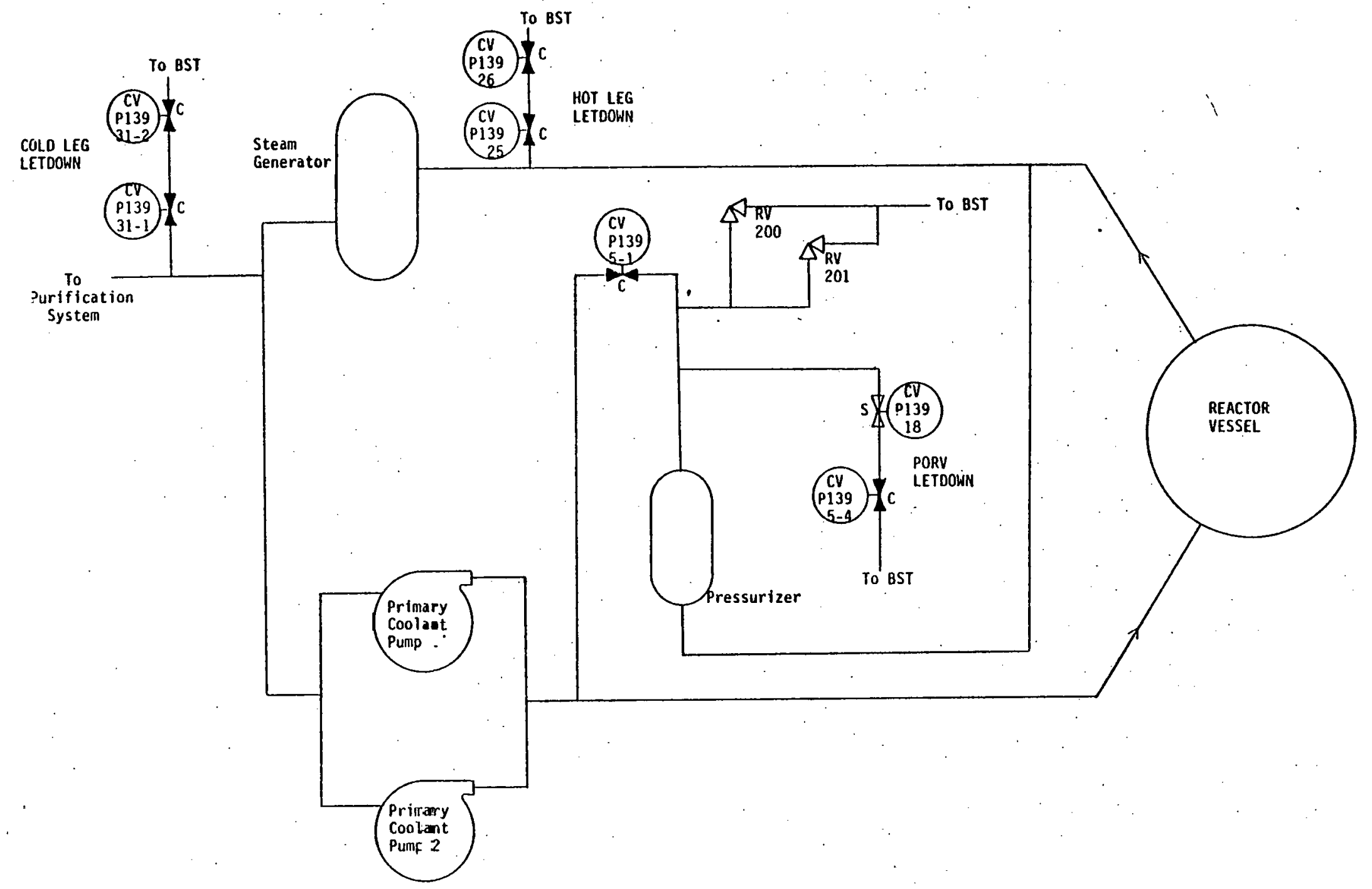

Figure 9. LOFT primary coolant system 

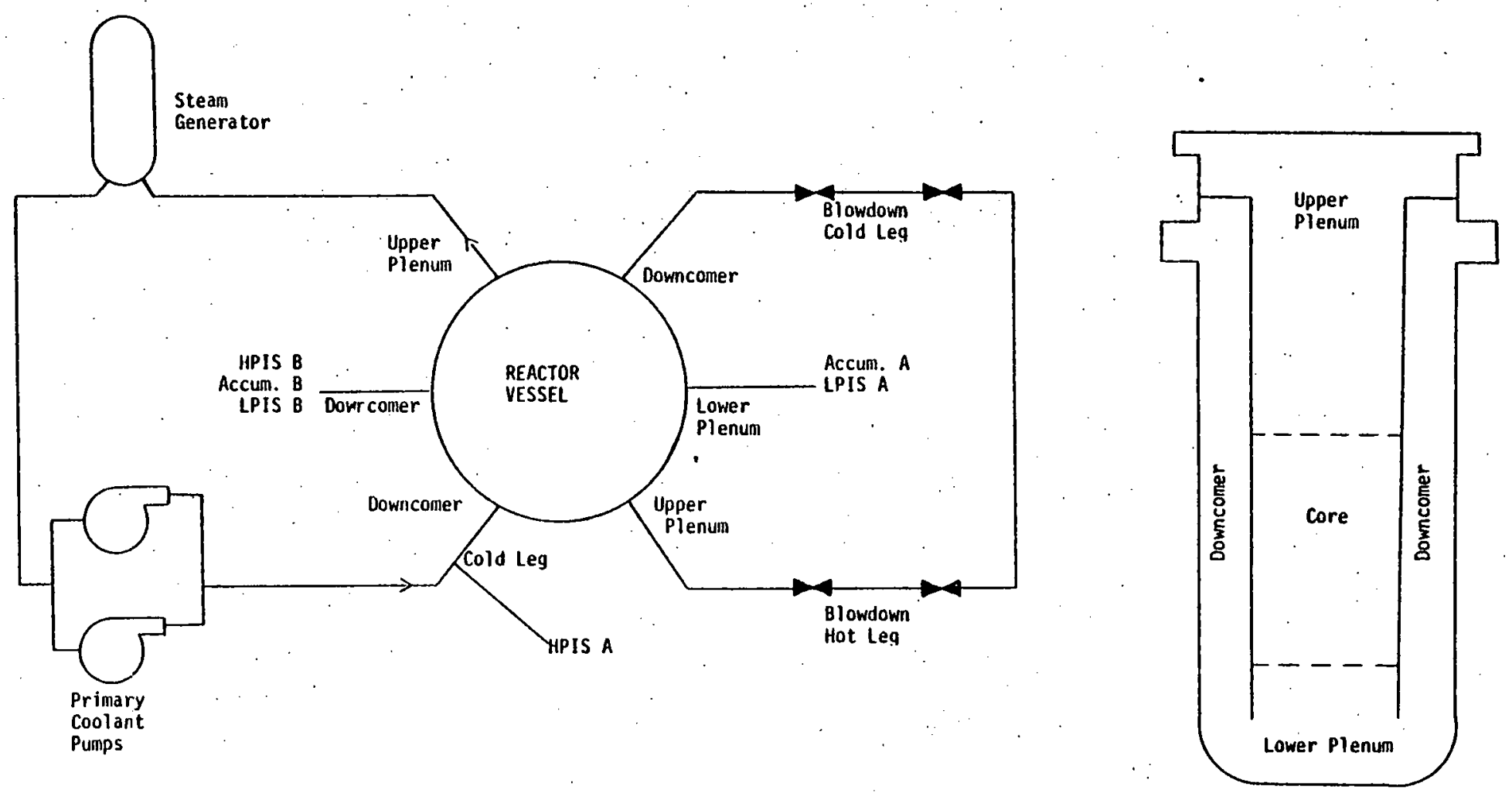

Figure 10. Injection points and reactor vessel regions 
Figure 11. Response trees for primary, secondary,purification, high pressure injection, and accumulator systems

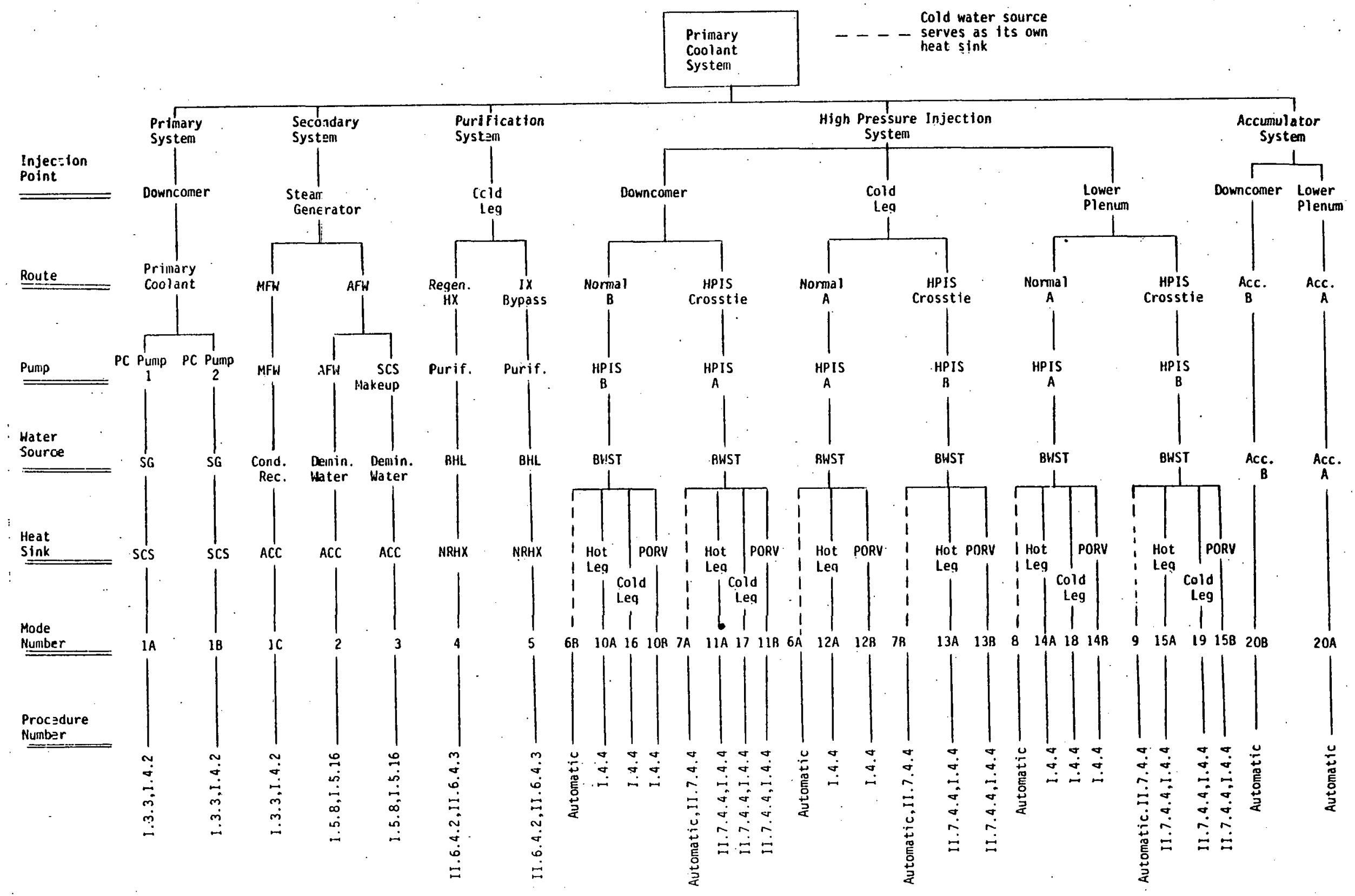


When the reactor is shut down, the steam generator can also be fed using the auxiliary feedwater pump or the secondary coolant makeup pump. These pumps take suction from the demineralized storage tanks through the polishing demineralizer. Heat is again rejected at the Air Cooled Condenser.

Figure 12 shows the layout for the secondary coolant system. Figure 11 shows the response tree for the system.

\subsubsection{Purifieation. System.}

When the reactor is shut down, decay heat can be removed from the primary coolant system by the purification system. Primary coolant is removed from the system at the blowdown hot leg. It passes through the tube side of the regenerative heat exchanger and the nonregenerative heat exchanger (NRHX). Heat is removed from the primary coolant in the nonregenerative heat exchanger by the primary component cooling (PCC) system. If the temperature of the primary water at the outlet of the $N R H X$ is less than $140^{\circ} \mathrm{F}$, the purification pump returns the water to the primary system through the purification ion exchanger. If the water temperature is greater than $140^{\circ} \mathrm{F}$, the ion exchanger is bypassed to protect the ion exchange resins. The cooled water is returned to the primary system at the primary coolant pump suction.

Figure 13 is the schematic for the LOFT purification system and Figure 11 is the response tree for the purification system.

\subsubsection{Emergency Core-Eooling System-(EECS).}

The Emergency Core Cooling System (ECCS) can be used to remove decay heat from the Primary Coolant System. The ECCS is composed of three subsystems: the High Pressure Injection System (HPIS), the Accumulator System, and the Low Pressure Injection System (LPIS). 


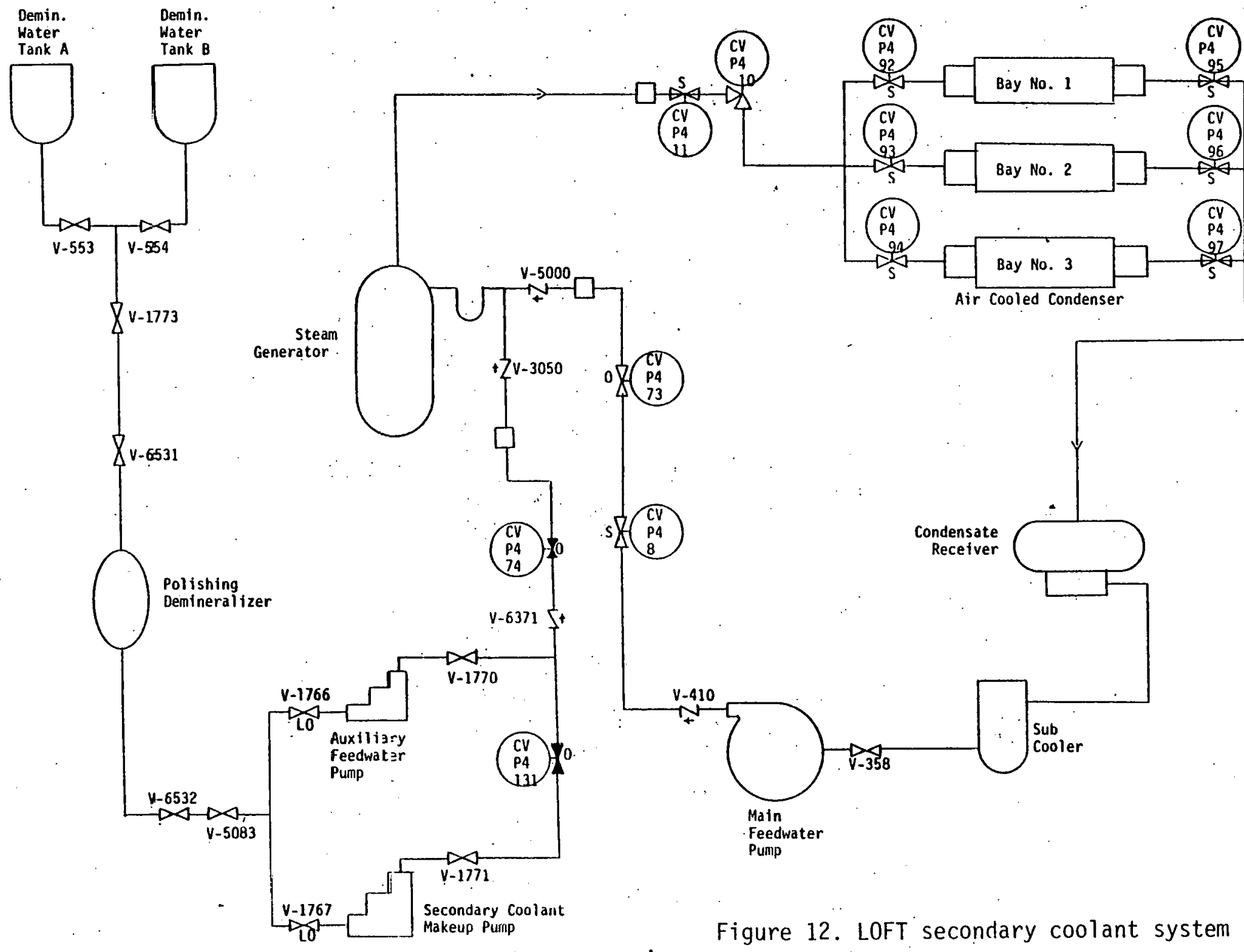




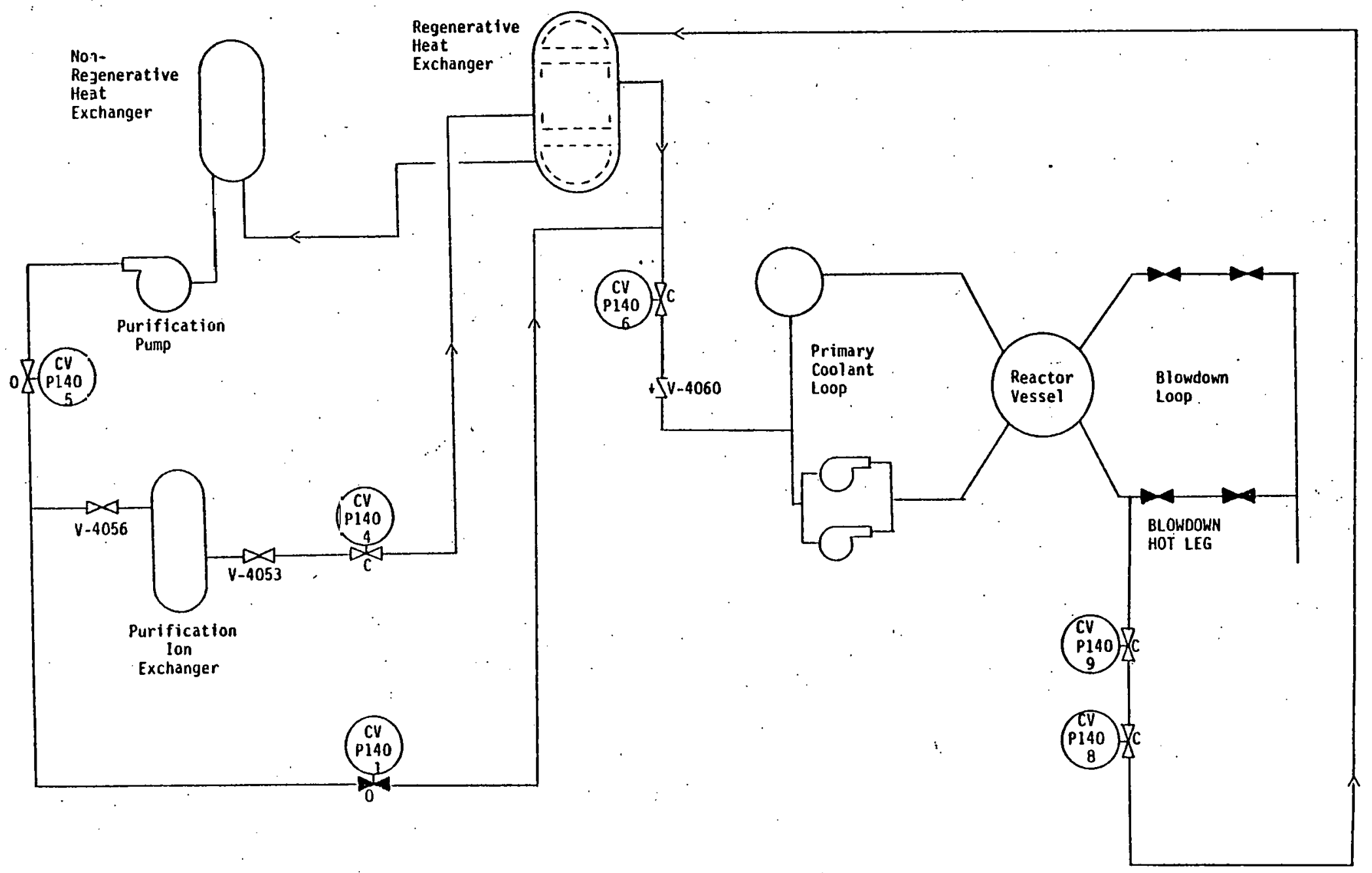

Figure 13. LOFT purification system 
The High Pressure Injection System is used to cool the primary coolant system at pressures above $190 \mathrm{psi}$. The HPIS is initiated automatically for LOCA situations but can be implemented manually for non-LOCA conditions. The HP IS pumps take suction from the Borated Water Storage Tank (BWST) and can inject cooling water into the primary system at the downcomer, lower plenum, or cold leg injection points. During LOCA conditions, the heated water is removed from the system at the point of the pipe rupture. For non-LOCA situations the water can be removed from the system through the hot leg letdown, cold leg letdown, or the power operated relief valves. The HPIS System also contains a crosstie line which may be used if necessary.

Figure 14 is the schematic of the HPIS and Figure 11 shows the response tree for the HPIS.

The Accumulator System consists of a pair of pressurized tanks holding cold water. The tanks are pressurized to $600 \mathrm{psi}$ and are isolated from the primary coolant system by check valves. When primary system pressure falls below 600 ps $i$ the accumulator water begins to flow to the primary system into . the downcomer and the lower plenum. Because of their limited capacities, the accumulators cannot be used for long term decay heat removal.

Figure 14 shows the arrangement of the Accumulator System. Figure 11 shows the response tree for the Accumulator System.

The Low Pressire Injection System can be used to cool the primary coolant system at pressures less than $190 \mathrm{psi}$. The two LPIS pumps normally take suction from the Borated Water Storage Tank (BWST), but during recirculation situations suction can also be taken from the Blowdown Suppression Tank (BST), Blowdown Hot Leg $(B H L)$ or Pressure Reduction Sump. Injection to the primary system can be through the cold leg, lower plenum, or downcomer injection points. Heat rejertion can occur at the LPIS heat exchangers to the Primary Component Cooling (PCC) System or to the atmosphere if the cooling circuit is 
Figure 14. LOFT high pressure injection and accumulator systems

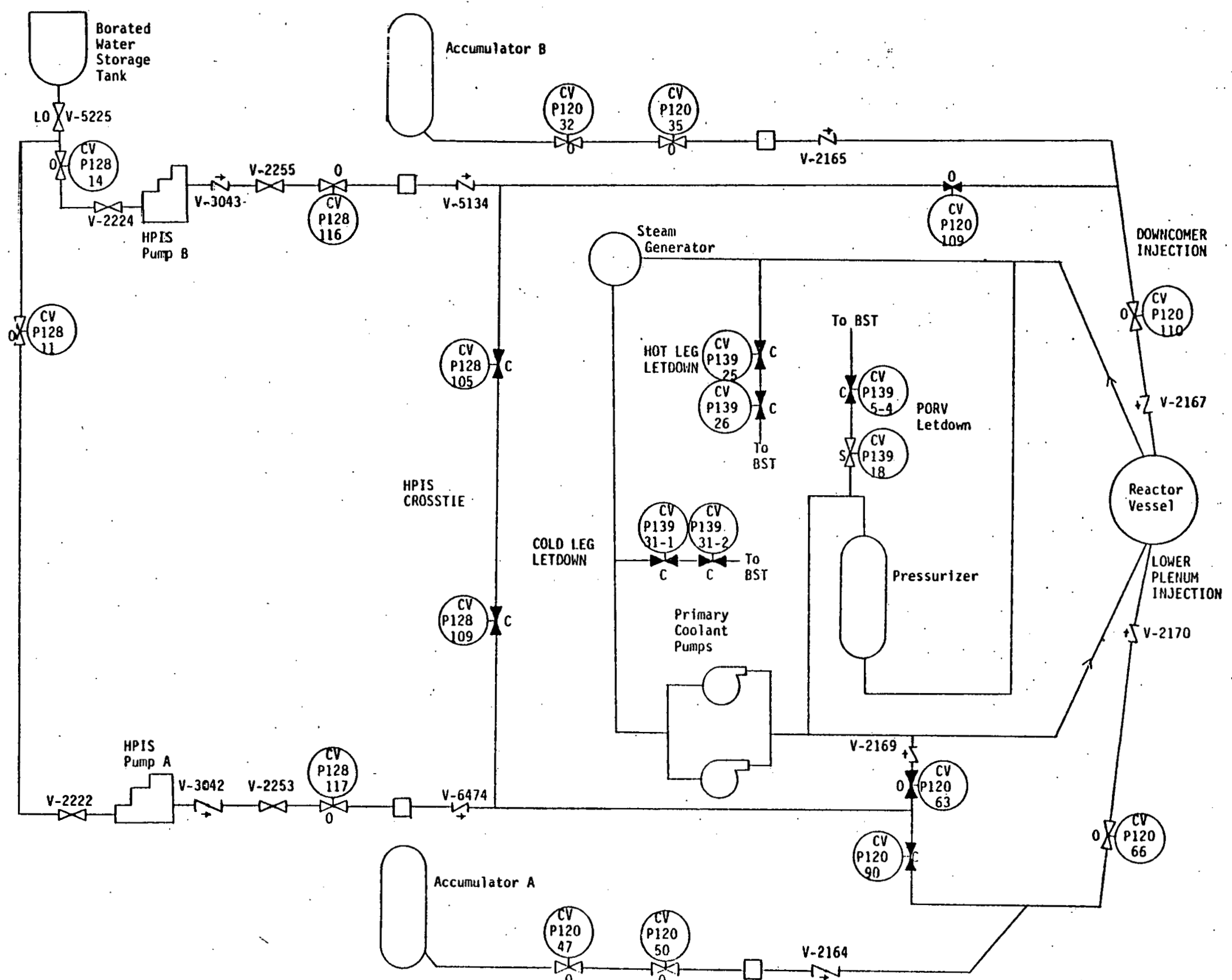


open to the atmosphere. Two crosstie lines are available: a manually operated line in the containment basement and another line which opens automatically when the ECCS is actuated.

Figure 15 shows the Low Pressure Injection System and Figure 16 is the response tree for the LPIS.

\subsubsection{Assignment- of Mode- Numbers.}

Mode numbers are used to assign relative priorities to cooling modes. In other words, when all else is equal, modes with smaller mode numbers will be implemented before those with larger numbers. Of course, other constraints must be considered. For example, some modes cannot be used when the system is at a high pressure. A general rule of thumb, then, is to utilize the mode with the smallest mode number which is appropriate for current conditions.

A set of assignment rules can be used for assigning mode numbers. The following set of assignment rules were used to assign the mode numbers for this report. These assignment rules are for demonstration purposes onty. To determine an acceptable set of assignment rules for LOFT or any facility would require extensive analysis and discussion by facility personnel.

The overall order of cooling system use is as follows:

1. Primary and Secondary Coolant Systems

2. Auxiliary Feedwater System

3. Purification System

4. High Pressure Injection System 
Figure 15. LOFT low pressure injection system

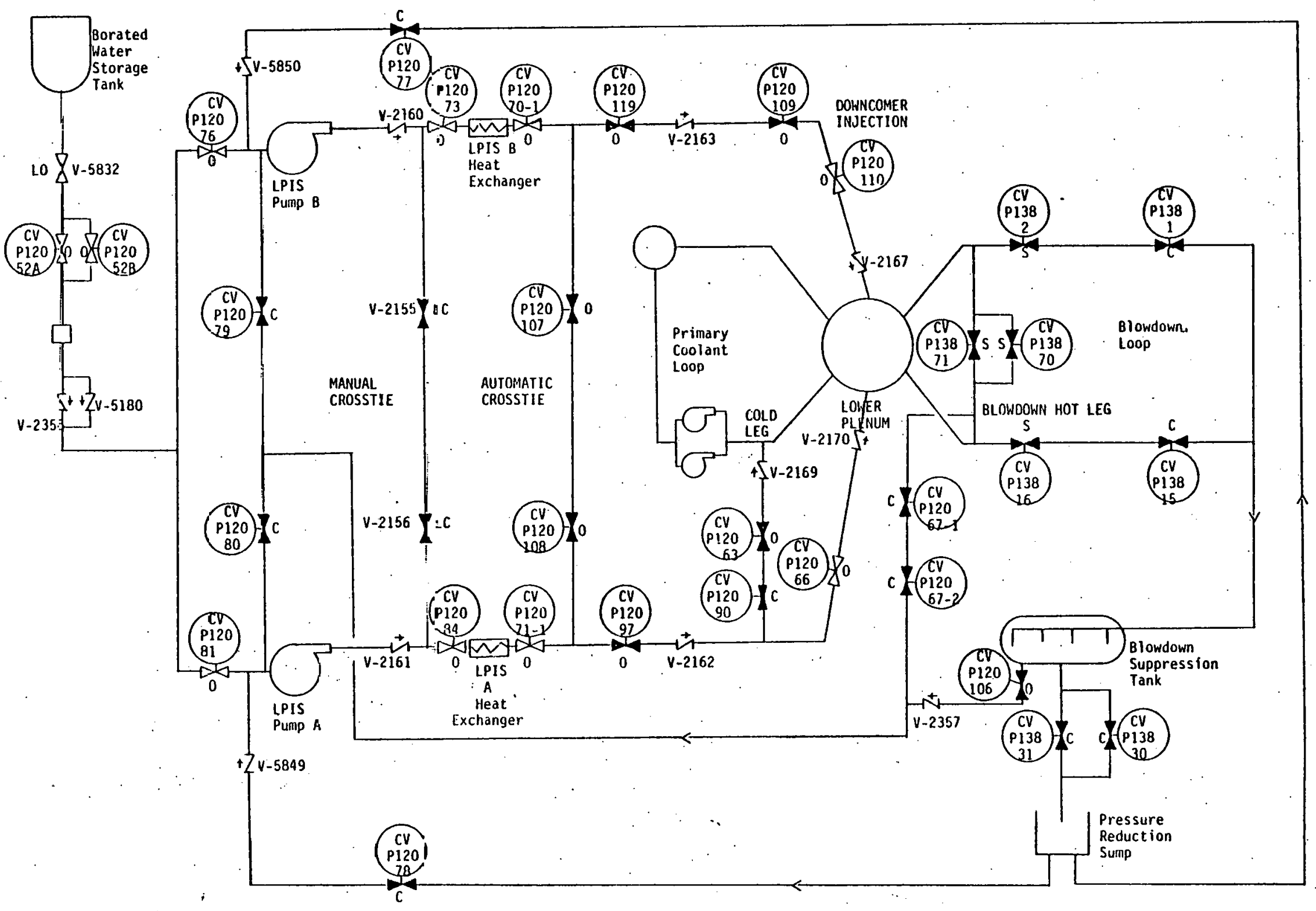


Figure 16. LFIS response tree

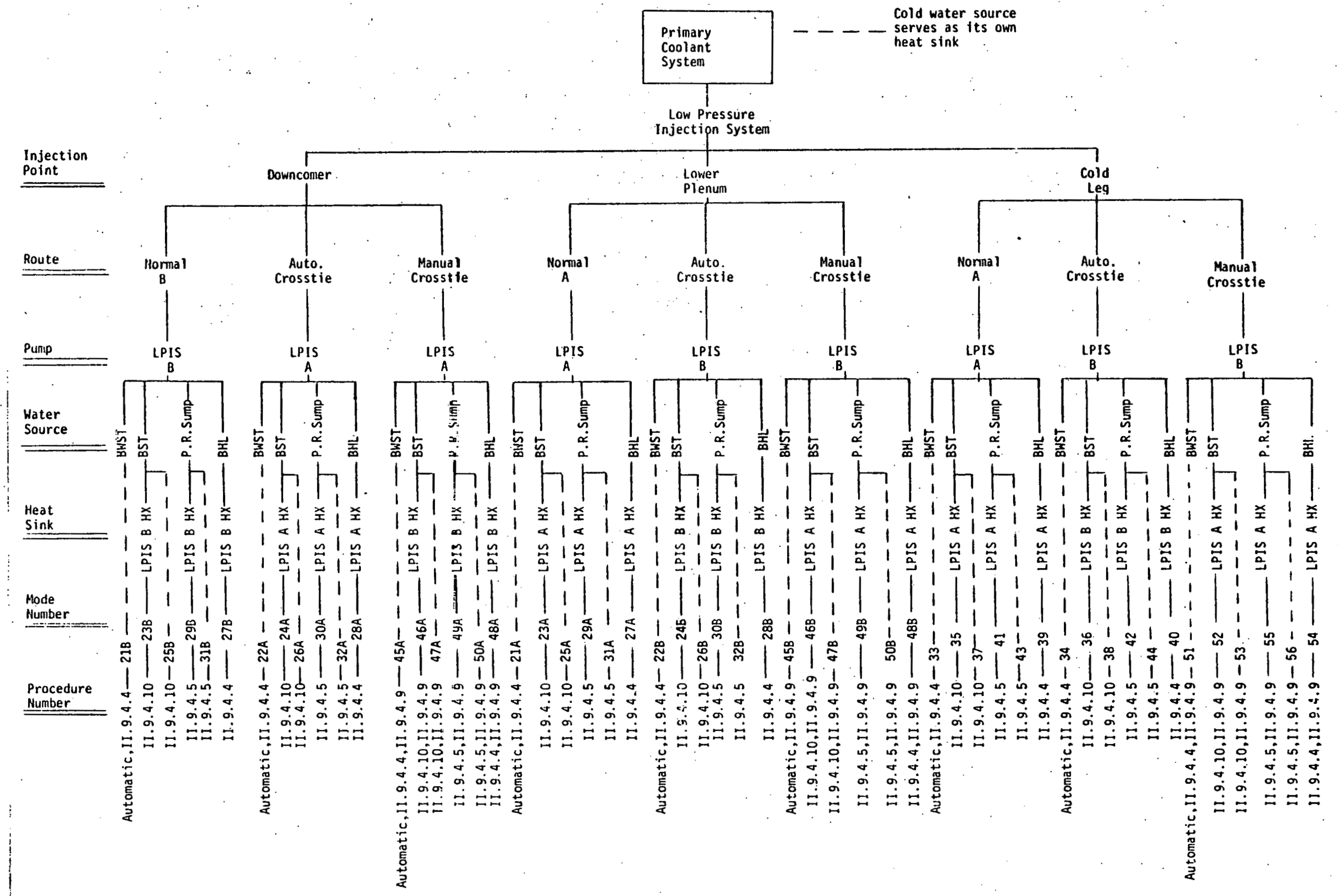




\section{Accumulator System}

6. Low Pressure Injection System

Other rules used for assigning mode numbers for this report are:

- Auxiliary feedwater pump is used before the secondary coolant makeup pump

- Purification ion exchange route is used before ion exchange bypass

- When using primary hot leg or cold leg letdown valves as the heat sink, lower plenum injection for HPIS is used before HPIS cold leg injection

- HPIS normal route is used before HPIS crosstie

- HPIS downcomer and cold leg injection are used before lower plenum injection

- Cold water heat removal is used before primary letdown heat removal (HPIS)

- Hot leg and power operated relief letdown heat removal are used before cold leg letdown (HPIS)

- Lower plenum injection is used before cold leg letdown heat removal (HPIS)

- Downcomer and lower plenum injection are used before cold leg injection (LPIS)

- LPIS normal route is used before LPIS crosstie route 
- Automatic crosstie route is used before manual crosstie (LPIS)

- Cold leg injection is used before manual crosstie route (LPIS)

- LPIS Heat Exchanger is used before cold water heat removal (LPIS)

- Automatic crosstie route is used before cold water heat removal (LPIS)

- Borated water Storage Tank (BWST) water source is used before Blowdown Suppression Tank (LPIS)

- Blowdown Suppression Tank water source is used before Blowdown Hot Leg (LPIS)

- Blowdown Hot Leg water source is used before Pressure Reduction. Sump (LPIS).

The assignment of mode numbers is a complex process. However, the use of a predefined, prioritized plan is necessary to minimize confusion following the occurrence of an accident.

\subsection{Support-Systems}

Many components of the systems used to cool the LOFT reactor depend on electrical or pneumatic support systemis to function.' When these support systems are disabled, many components are disabled and thus any cooling modes utilizing them may also be disabled. For example, the failure of a pneumatic supply will cause pneumaticaliy operated valves to go to their fail positions. The failure of an electrical supply will also cause control valves to assume their fail positions, and pumps which depend on the electrical system for power will not operate. The failure of a water system will disable any heat exchangers which utilize the system as a source of cooling water. 
Failure of a support system will cause many components throughout the plant to be unavailadle for use. The effects of such a failure can thus be illustrated on the response trees. The response trees showing the failure of a support system can then be used as an "overlay" with any other component failures. Response trees have been developed for the failure of important support systems at LOFT. The trees were developed using the component attribute tables of Appendix $C$. These tables list the support systems utilized by components of the cooling modes considered in this study. The tables also show the normal and fail positions of control valves.

The response trees showing the effects of support system failures show direct effects of the failure only. Indirect failures nave not been considered. For example, the failure of commercial power will disable the Instrument Air compressors, causing the IA System to gradually depressurize. However, results of IA System failure nave not been snown on the response tree for loss of commercial power. To illustrate this effect both trees are required. Other support system interactions are more complex and nave not been considered in this study.

\subsubsection{Commercial Power.}

The LOFT facility is supplied with offsite commercial power from two separate sourçes. Figure 17 snows the cooling modes which are disabled by the loss of commercial power. The primary coolant, main feedwater, and purffication pumps are dll disabled by a luss of commercidl puwer. Valves CV-Pl40-4, 6, 8, and 9 fail closed, disabling all purification system.cooling modes. Valves $\mathrm{CV}-\mathrm{P} 120-67-1$ and $67-2$ also fail closed, making it impossible to use the blowdown not leg for LPIS cooling.

\subsubsection{Vital Power.}

LOFT has two vital power systems, Vital Power A and Vital Power B. Both systems are normaliy powered from commercial sources. When commercial power - is lost, Danks of submarine batteries assume vital loads. If the loss of 
Figure 17. Loss of commercial power

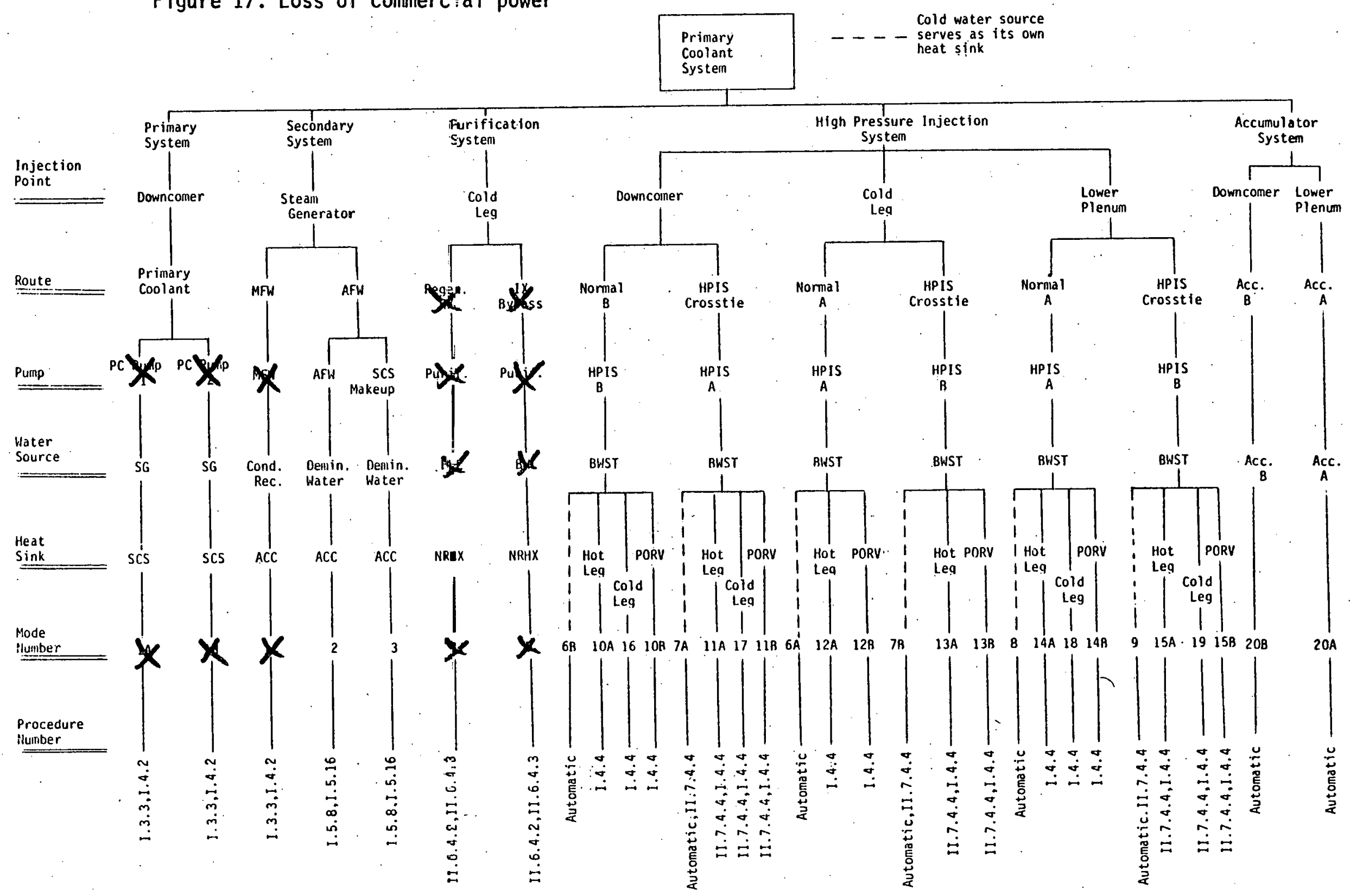


Figıre 17. (cont.)

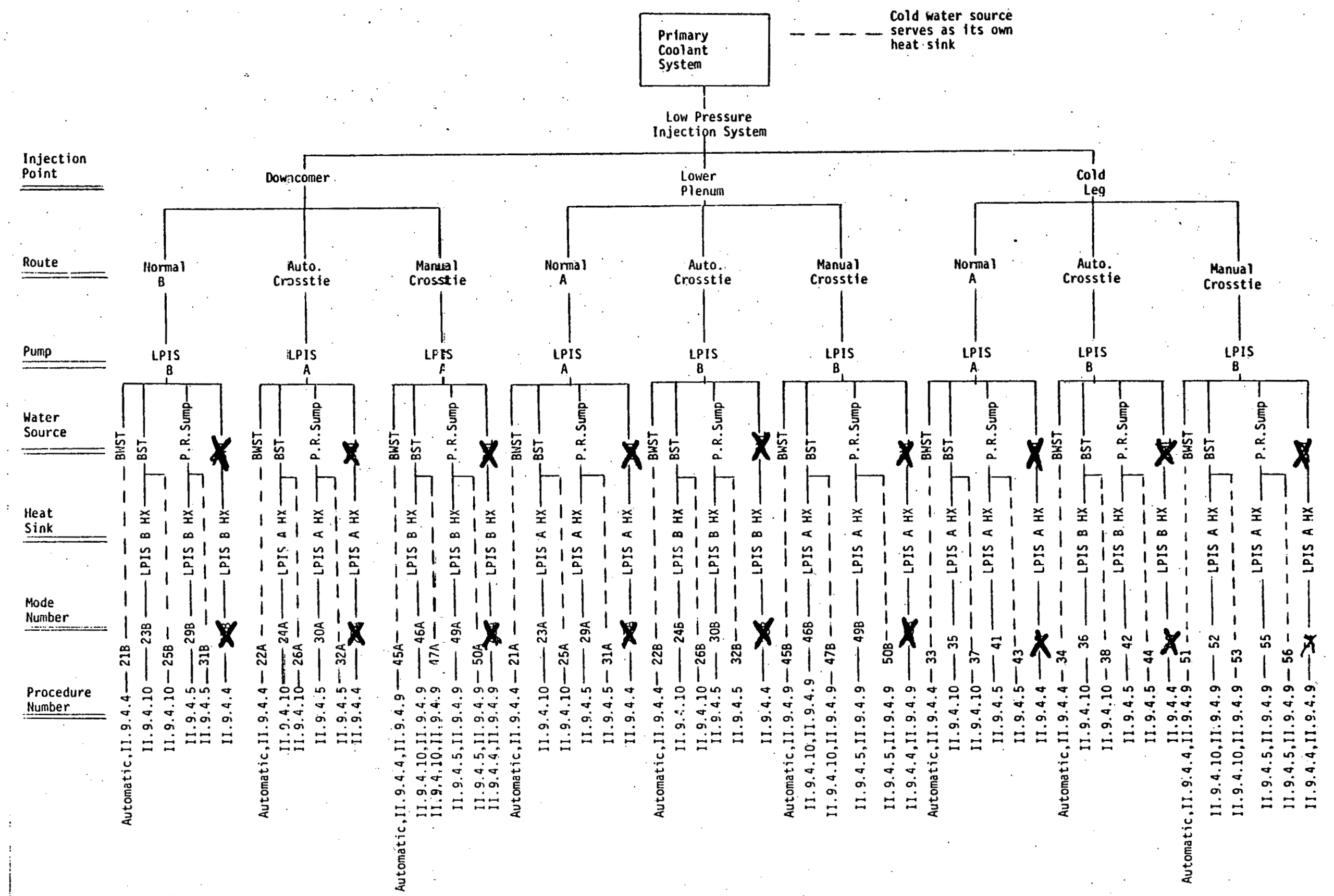


power is extended, each vital bus has a diesel generator which can be started to maintain the vital loads. The High Pressure Injection and Low Pressure Injection pumps are powered by vital power.

Figure 18 shows the results of a loss of Vital Power $A$. The auxiliary. feedwater pump is disabled by a loss of Vital $A$, disabling cooling mode 2 . In addition, HPIS pump $A$ and LPIS pump $A$ are disabled, and valves CV-P128-109, CV-P139-25 and 26, and CV-P120-66, 80, and 90 fail closed, disabling many HPIS and LPIS cooling modes.

Figure 19 shows the effects of the failure of Vital Power B. Failure of Vital $B$ disables the secondary coolant makeup pump (cooling mode 3 ). HPIS pump B and LPIS pump B cannot be used, and valves CV-P128-105, CV-P139-31-1 and $37-2$, and $C V-P 120-77$ and 79 fail closed. The effects of these failures are shown on the figure.

\subsubsection{Preumatic Stpplies.}

The LOFT facility has three pneumatic supplies, Instrument Air (IA), Inert Gas I (IG-I) and Inert Gas II (IG-II). The Instrument Air system is pressurized using air compressors. Both inert gas systems are pressurized from large nitrogen. storage tanks. The failure of a pneumatic supply due to failure of a compressor or rupture of its pressure boundary will cause many valves to move to the ir fail positions. This can result in the unavailability of various cooling modes.

Figure 20 shows the results of a loss of Instrument Air. The failure of the IA system causes valves to fail shut. in the purification system, HPIS crosstie, PORV letdown, hot leg letdown, and LPIS A suction from the pressure reduction sump, blowdown suppression tank, and blowdown hot leg.

Figure 21 illustrates the effects of a failure of the Inert Gas I System. The loss of IG-I causes CV-P120-90 to fail closed, making it impossibie to inject HPIS water into the lower plenum or LPIS water into the cold leg. 
Figure 18. Loss of Vital Power A

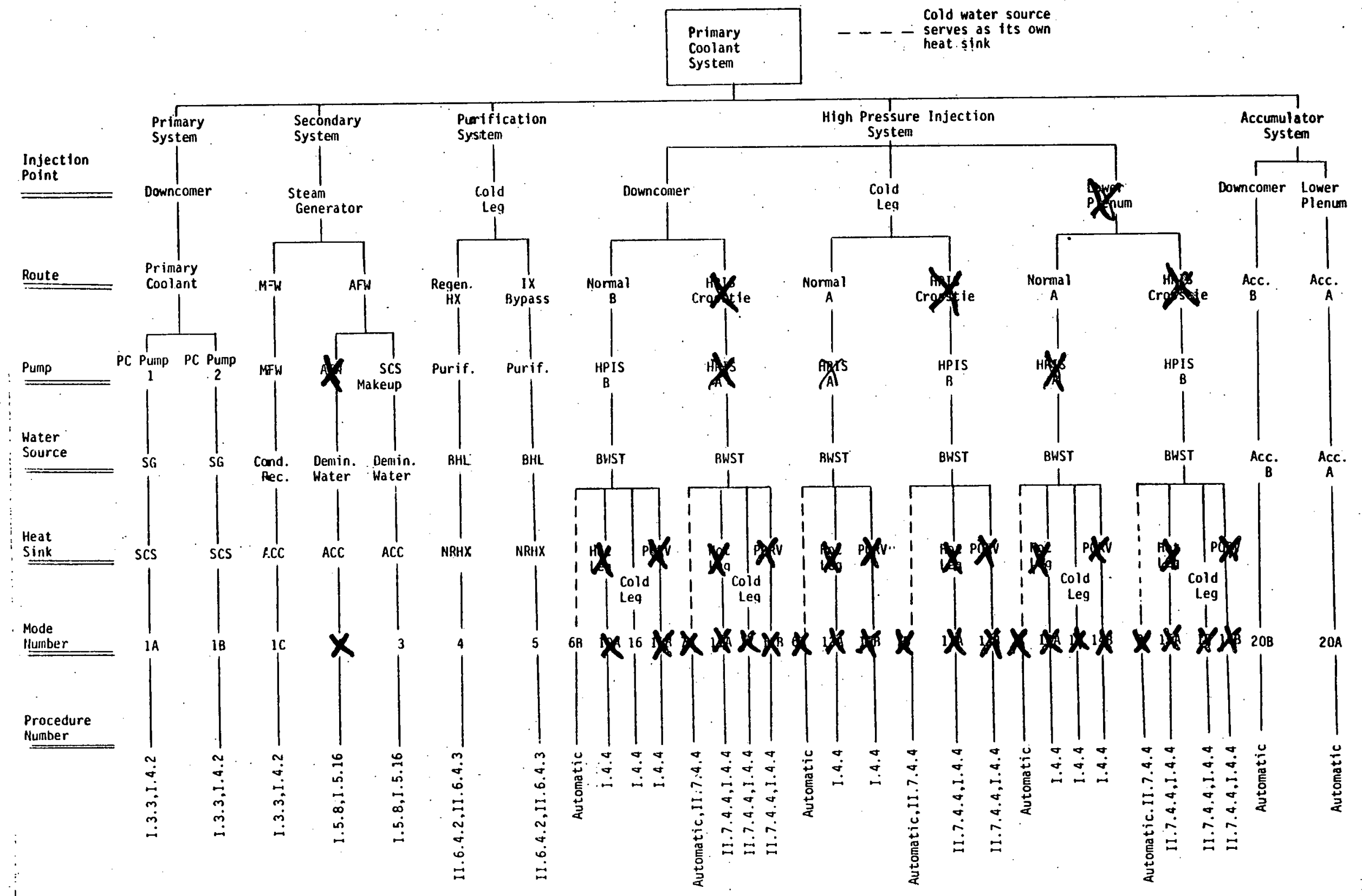


Figure 18. (cont.)

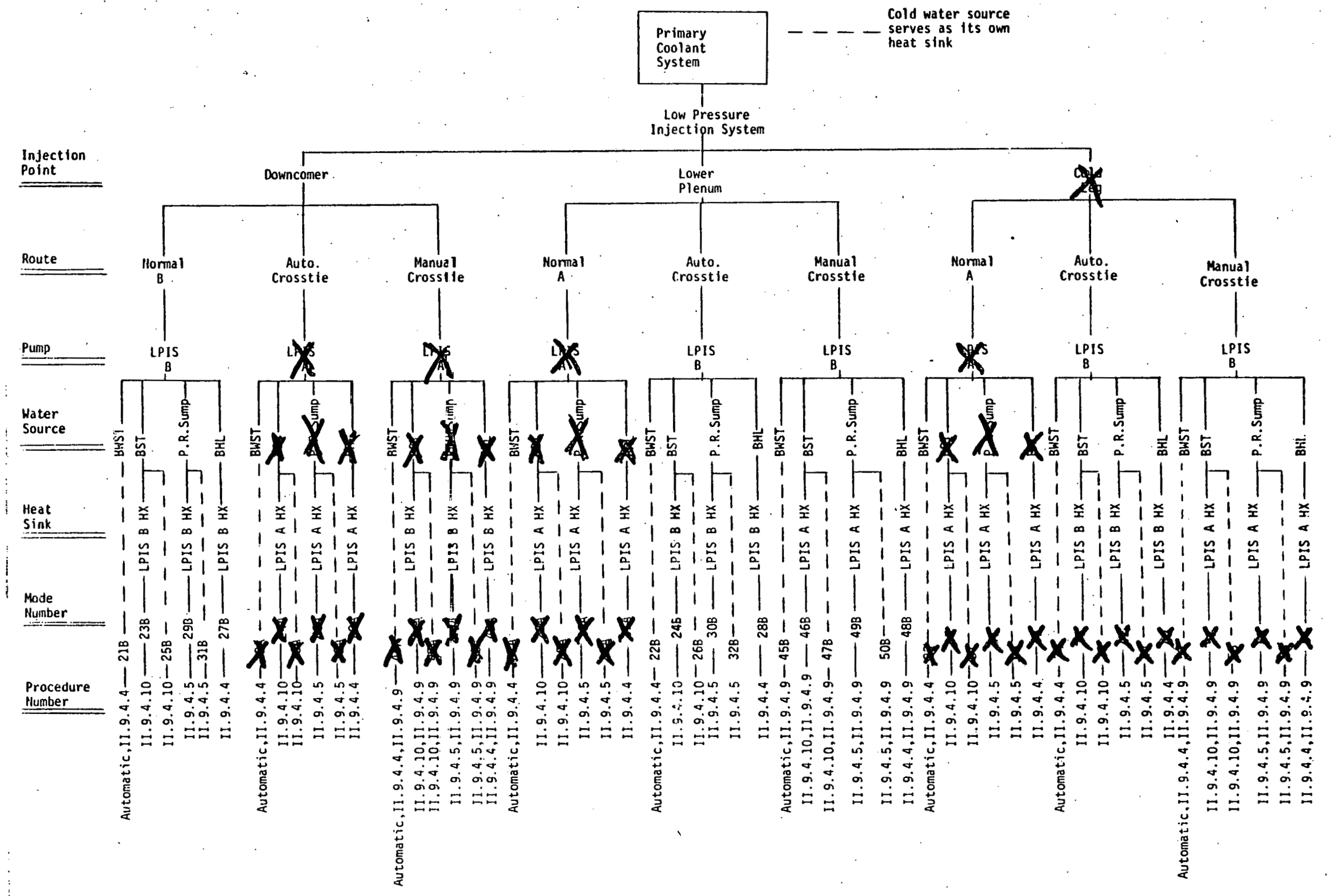


Figure 19. _oss of Vital Power B

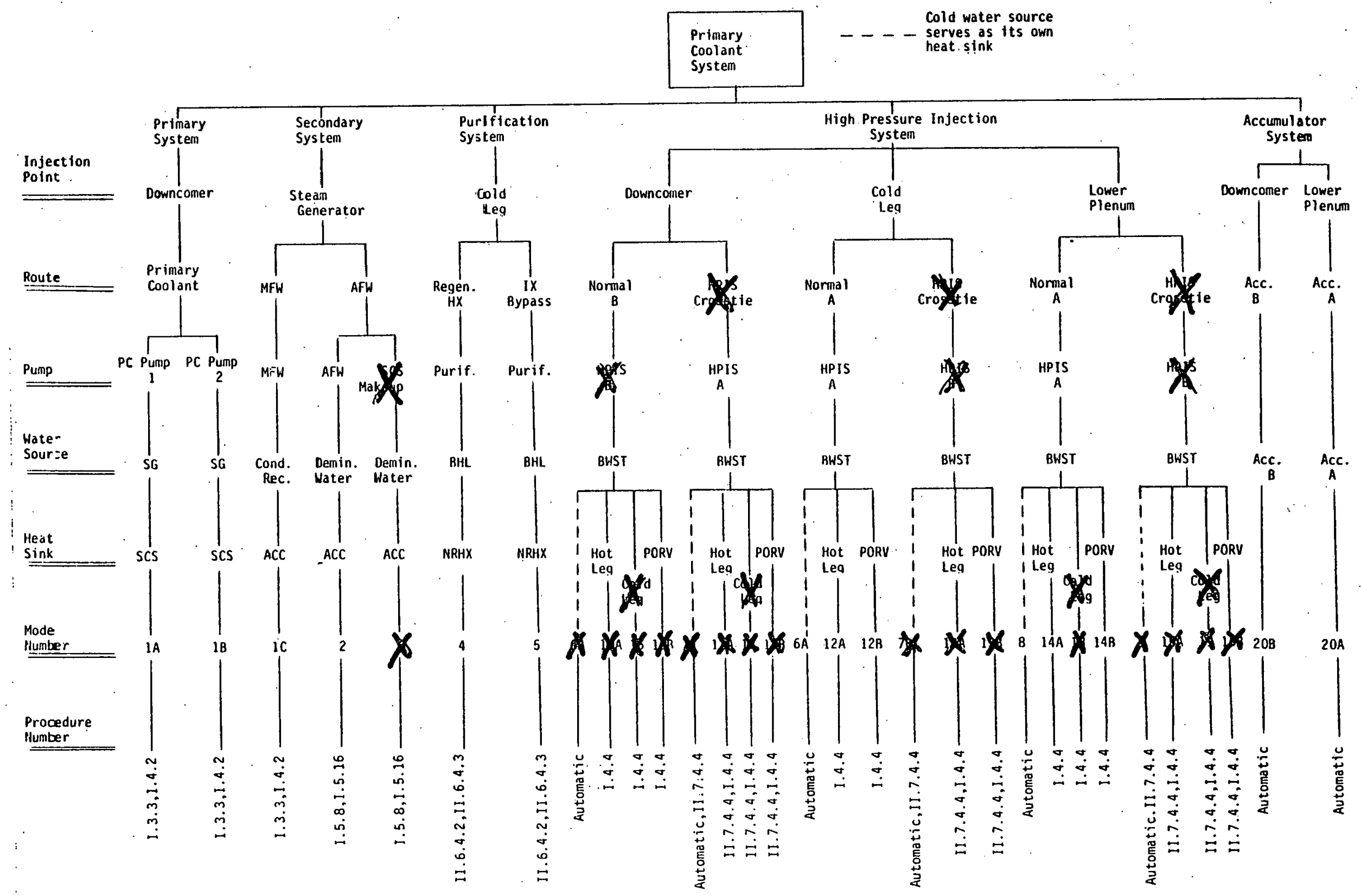


Figure 19. (cort.)

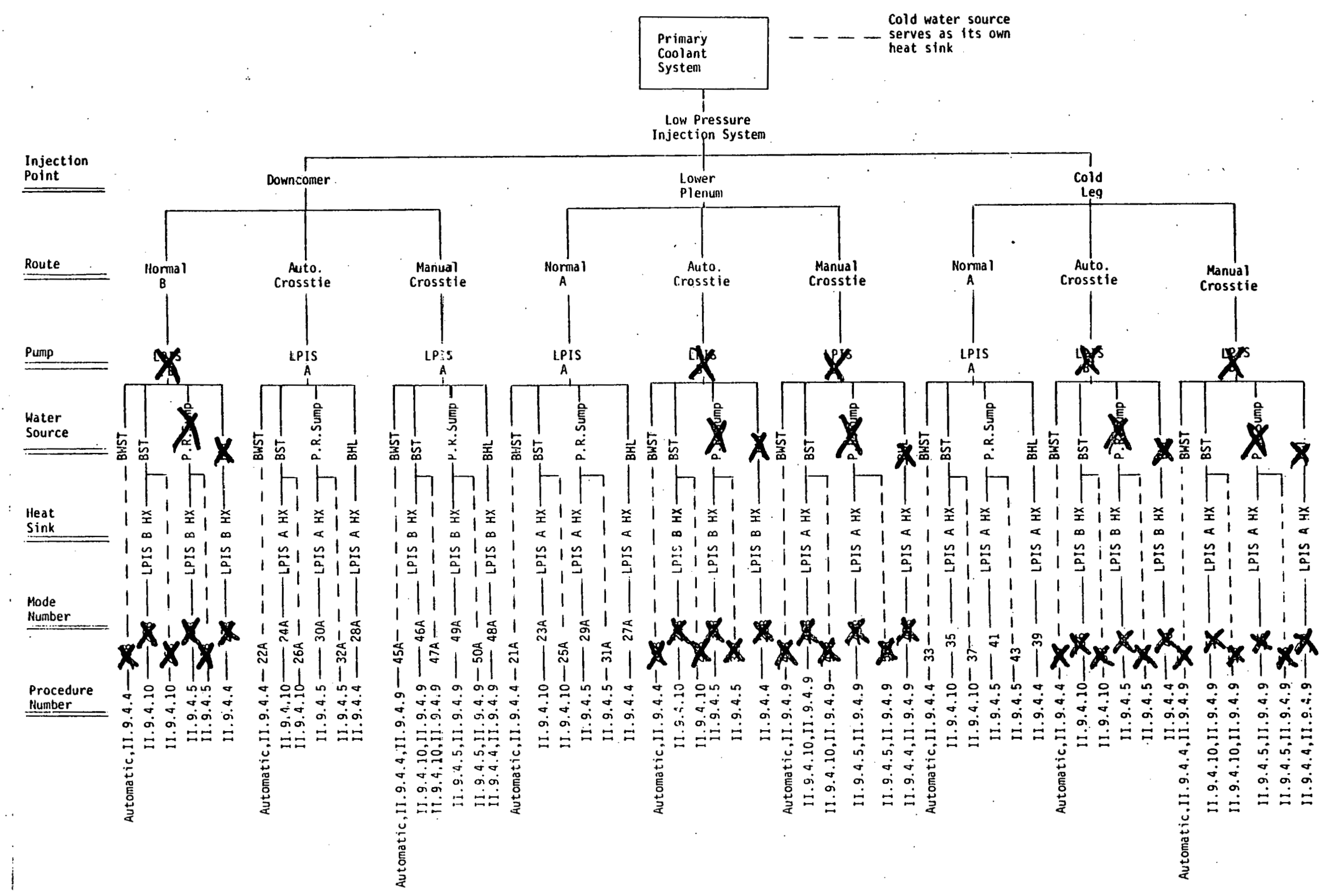


Figure 20. Loss of Instrument Air

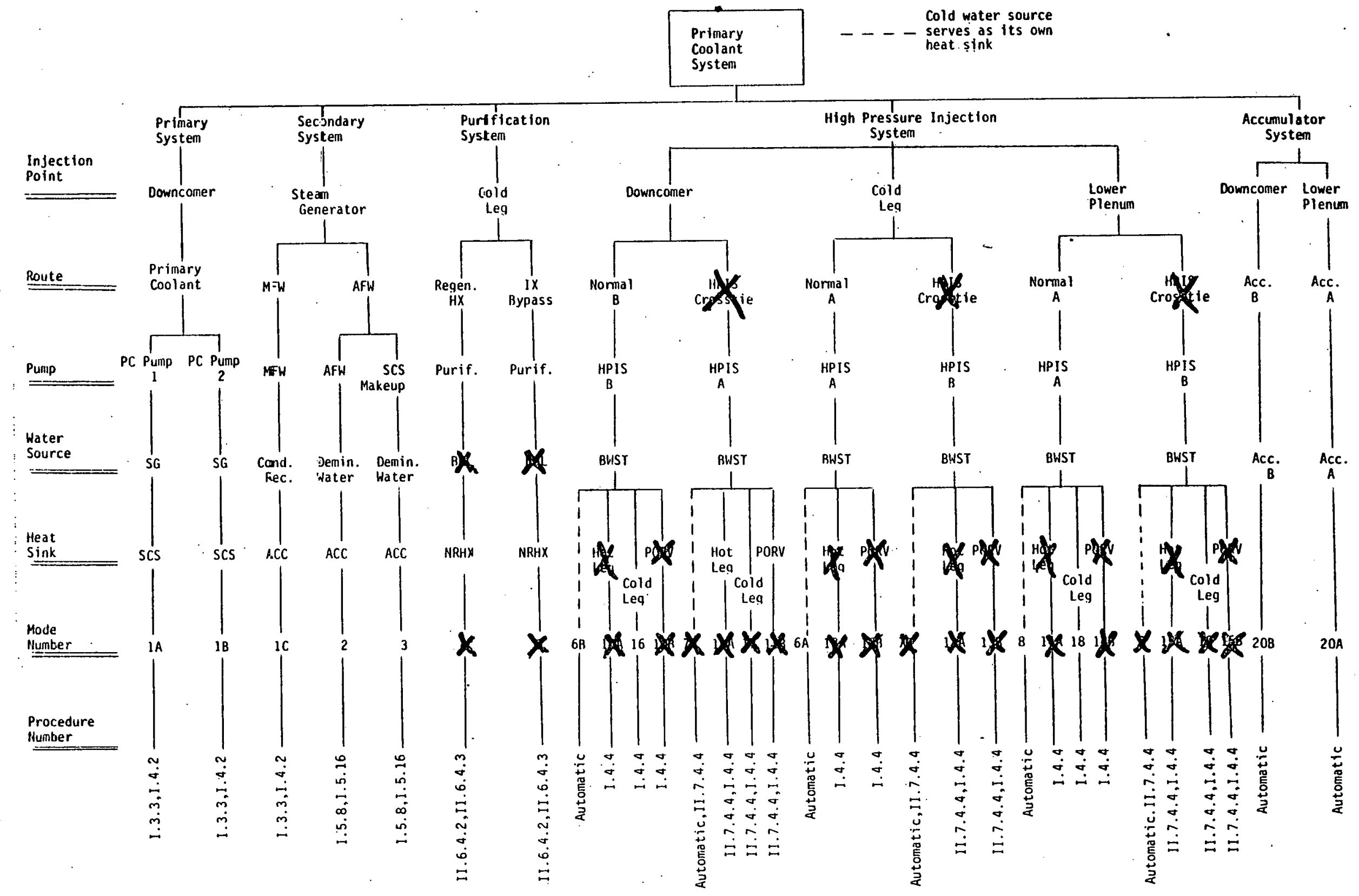


Figure 20. (cont.)

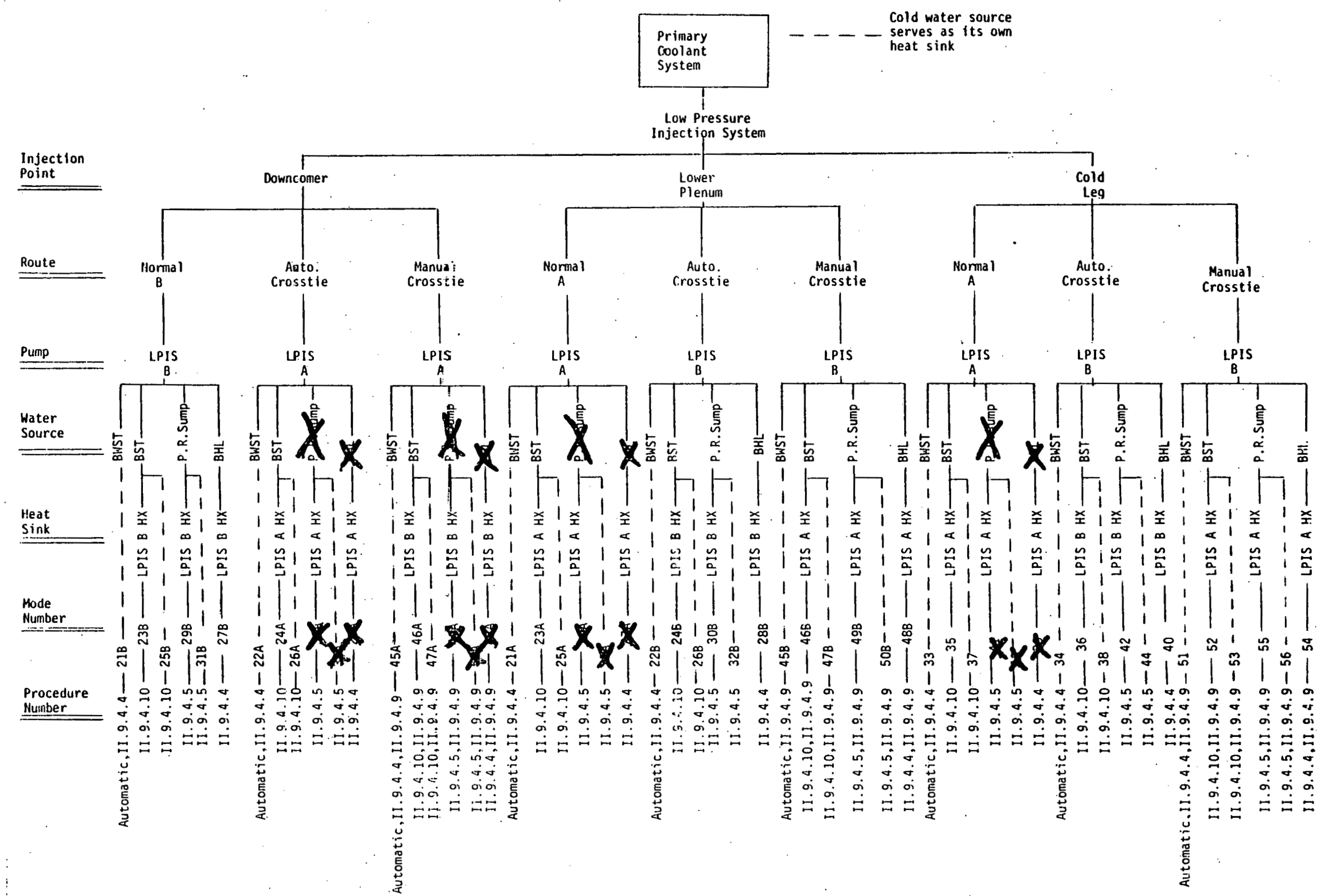


Figure 21. Loss of Inert Gas I

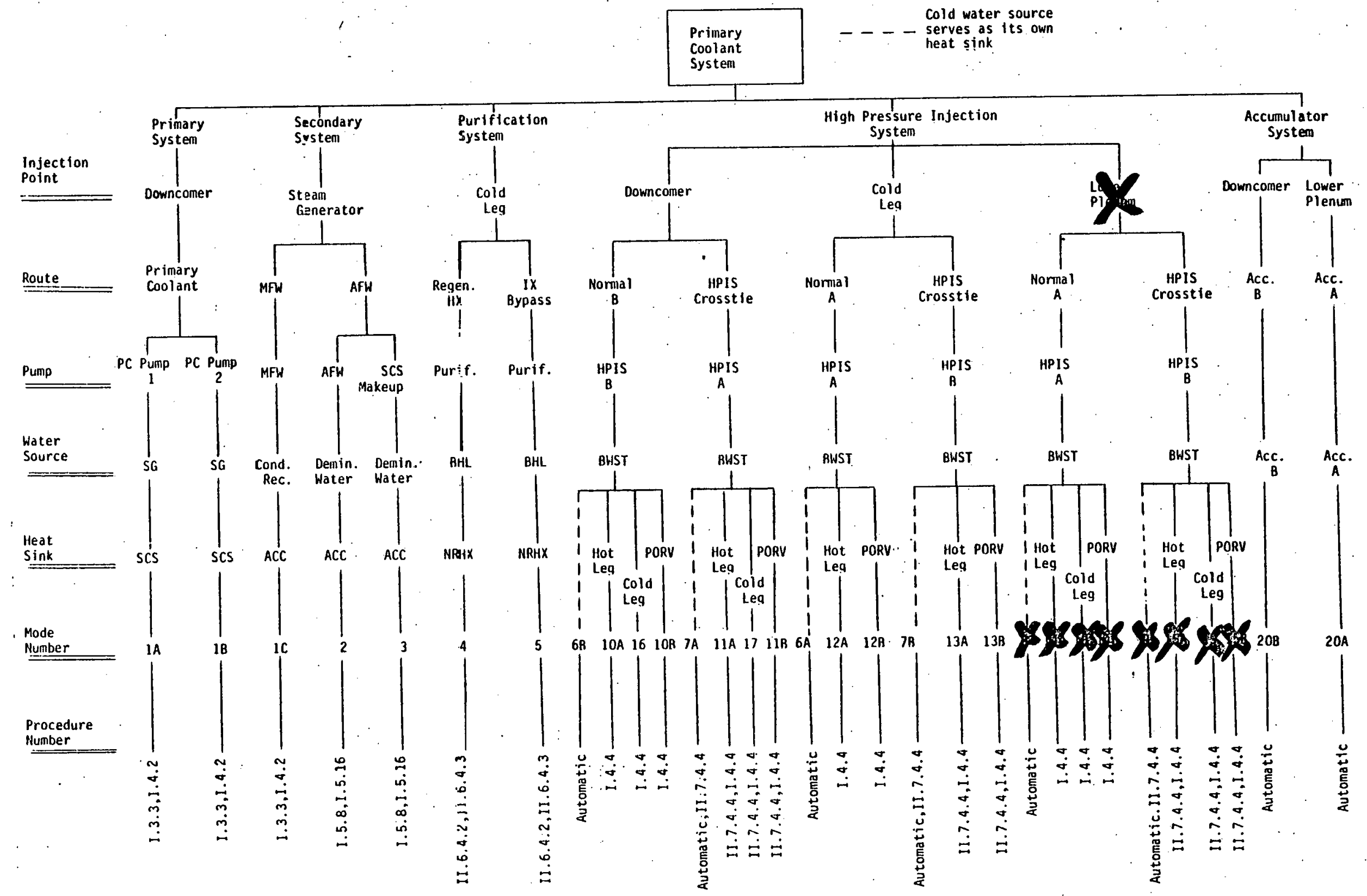


Figure 21. (cont.)

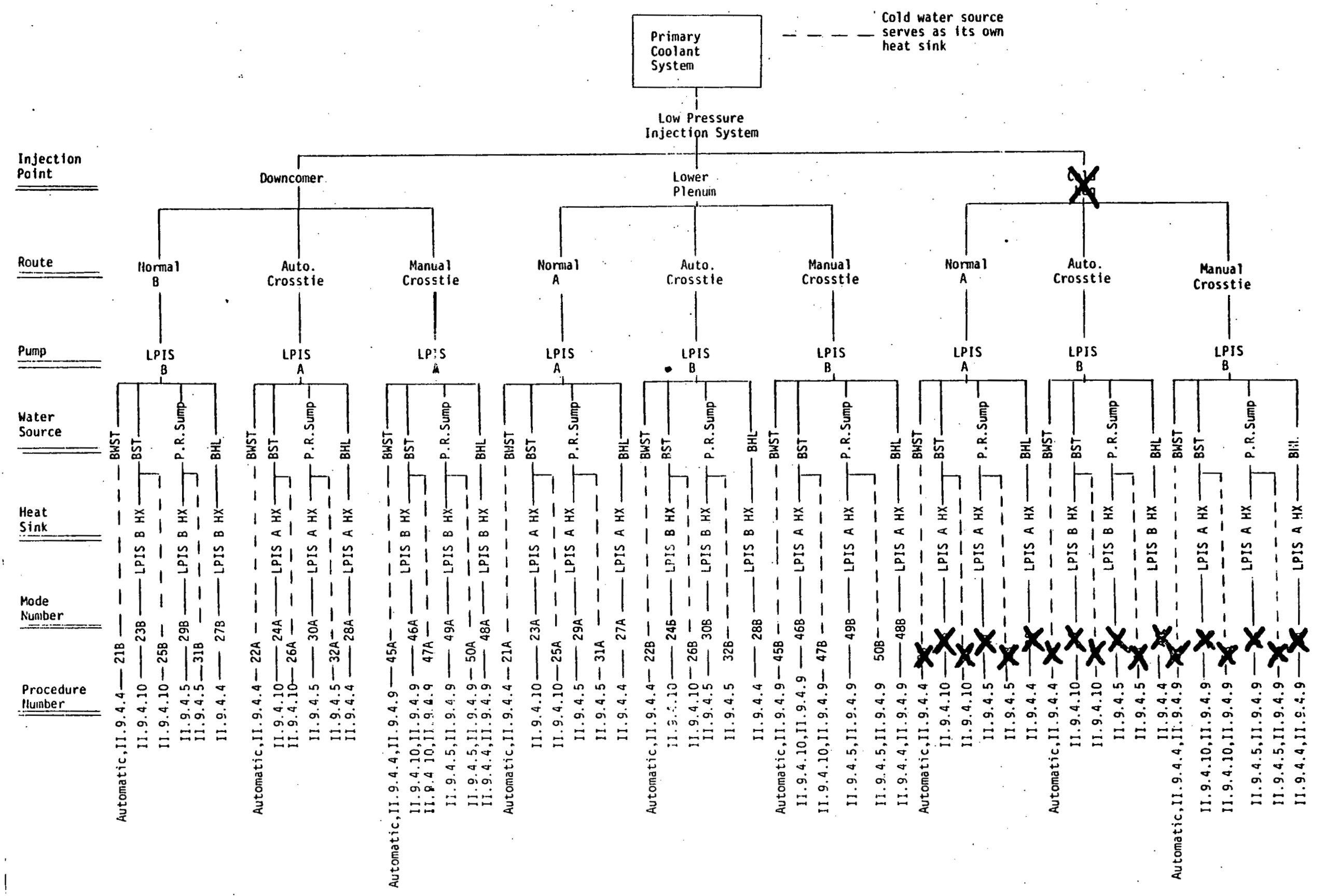


Figure 22 shows the effects of the failure of the Inert Gas II system. Note that failure of IG-II does not disable any cooling modes.

\subsubsection{Service. Water.}

The service water system provides cooling water to certain components and heat exchangers, particularly the LPIS heat exchangers. Figure 23 shows the effects of a failure of the service water system.

\subsection{Detection-and-Diagnosis-of-Cooling-Mode-Malfunctions}

The main function of the response tree is to direct the operator to an alternate cooling mode when a malfunction is detected in the mode being utilized. In this sense, it is not always necessary to determine the exact cause of cooling mode trouble, only to detect that a problem exists and substitute another cooling mode. In the long term, however, it is important to repair failed equipment so that more desirable cooling modes can be reinstated if desired. For this reason, it may be important to determine exactly where a failure has occurred and why it happened. For this purpose, generic symptom-cause information can be developed to assist fault diagnosis.

Cooling mode status can be diagnosed by many indications. Many components have direct indicators of their status. For example, the position of a control valve can be monitored on a position indicator in the control room. Other components have no direct indication of their status, and failures must be deduced from secondary indications. For example, the rupture of a pipe can be deduced from a loss of pressure in the pipe, a loss of flow downstream from the break, or excessive flow upstream from the break. Table 1 lists the primary and secondary indicators which can be used to monitor the status of components in various ronoling modes.

The performance of a particular cooling mode can be determined by either (1) the status of the components of the cooling mode or (2) the status of parameters in the reactor vessel itself. Table 2 lists symptoms which can be 
Figure 22. Loss of Inert Gas II

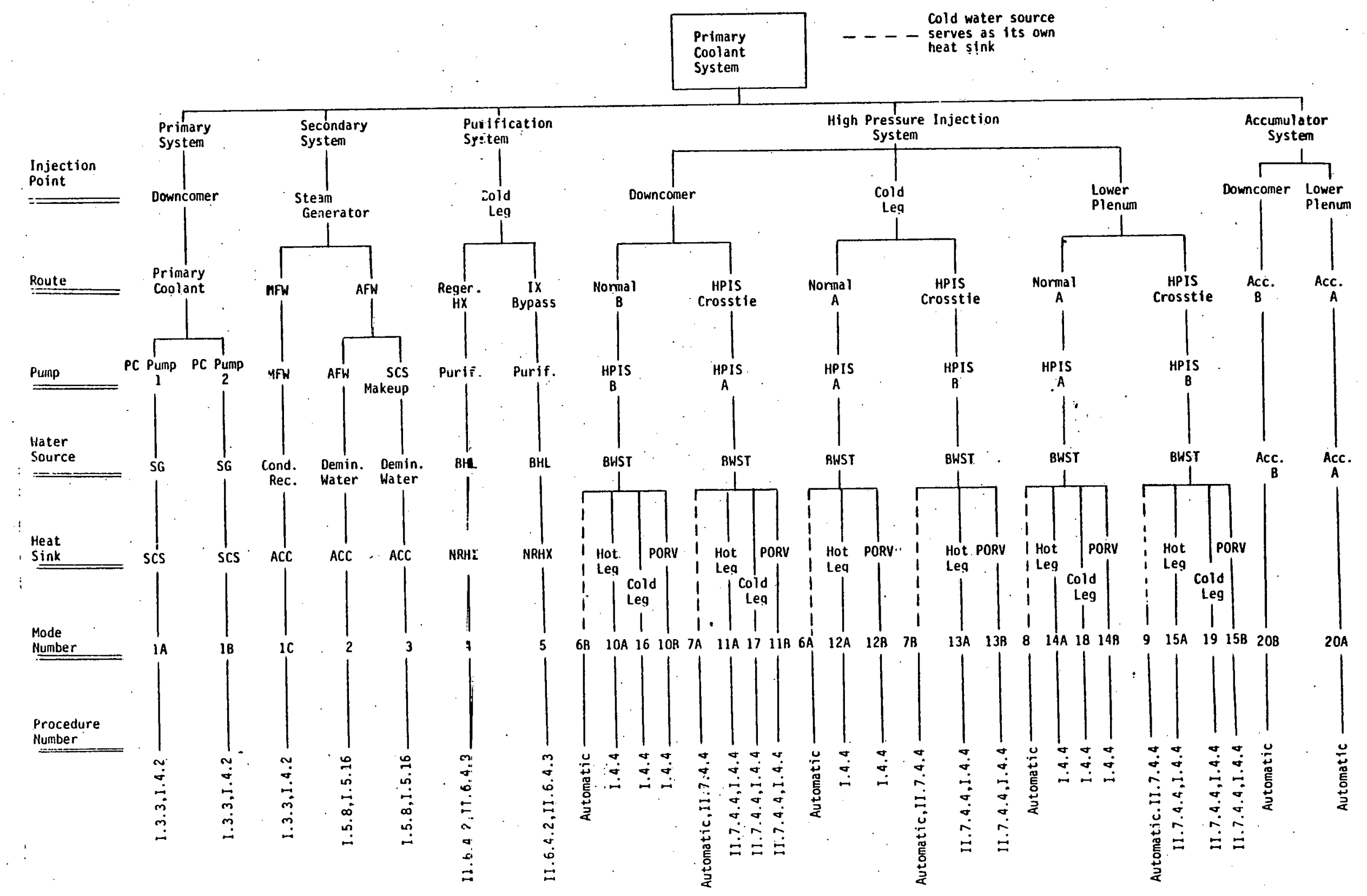


Figure 22 . (cont.)

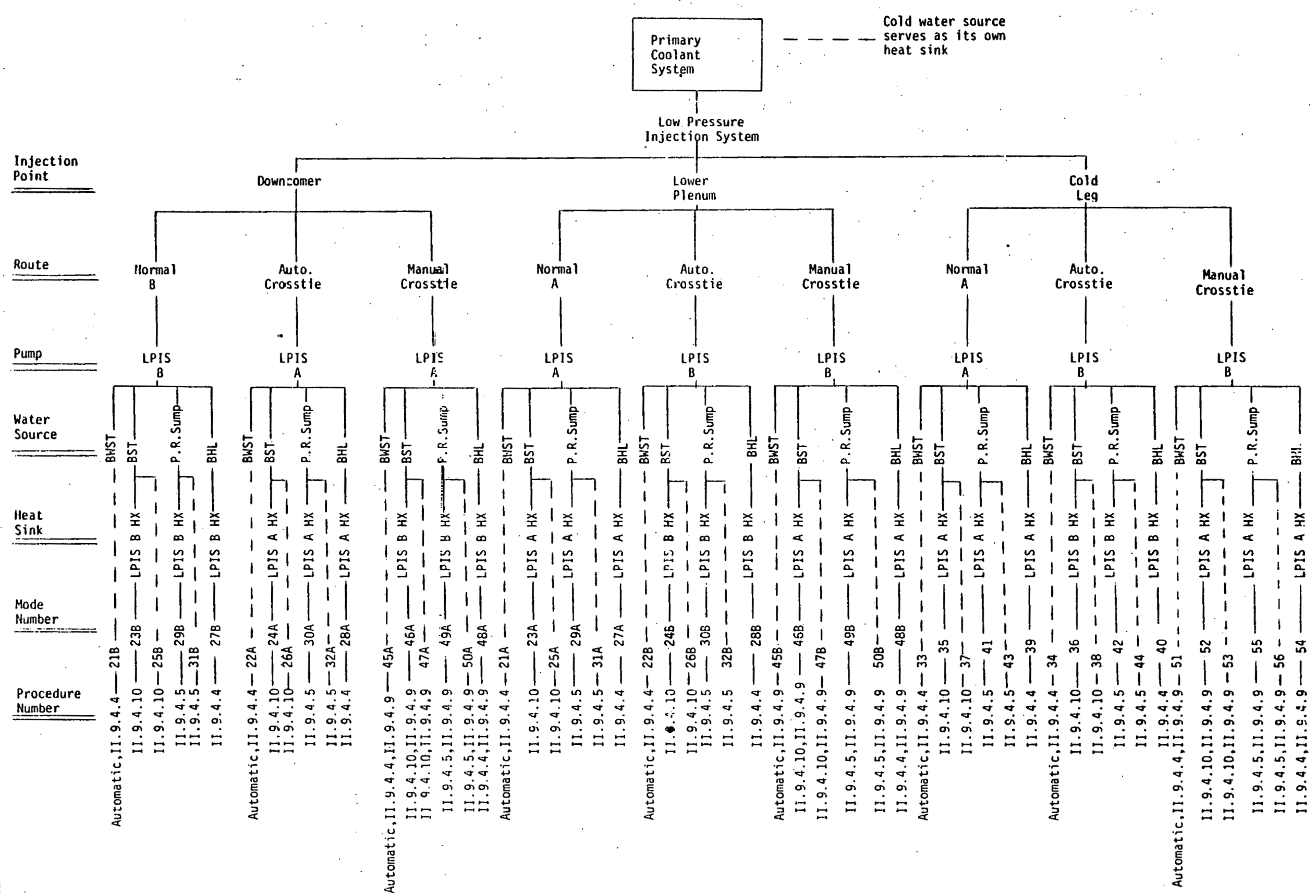


Figure 23. Loss of service water

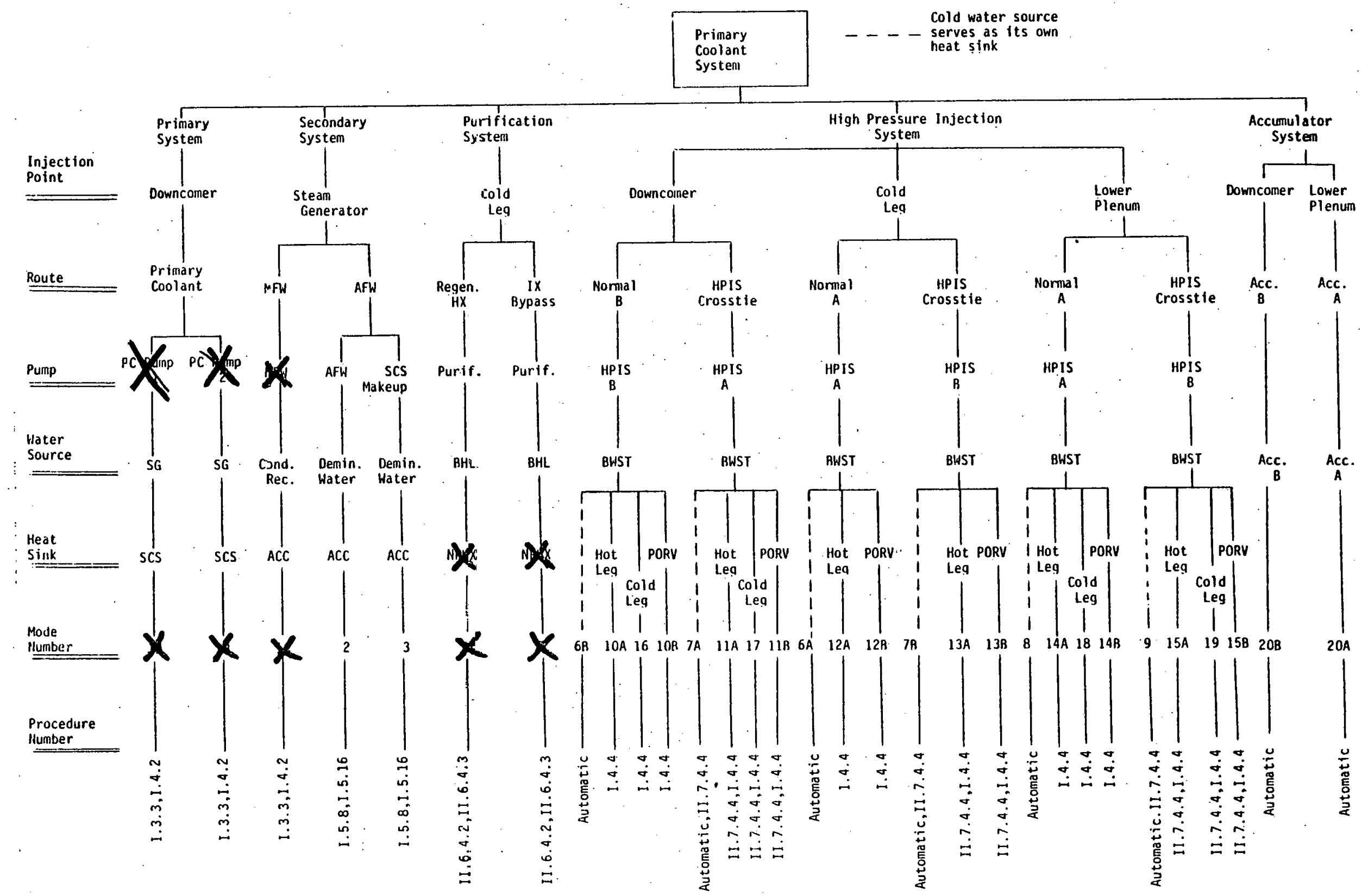


Figure 23. (cont.)

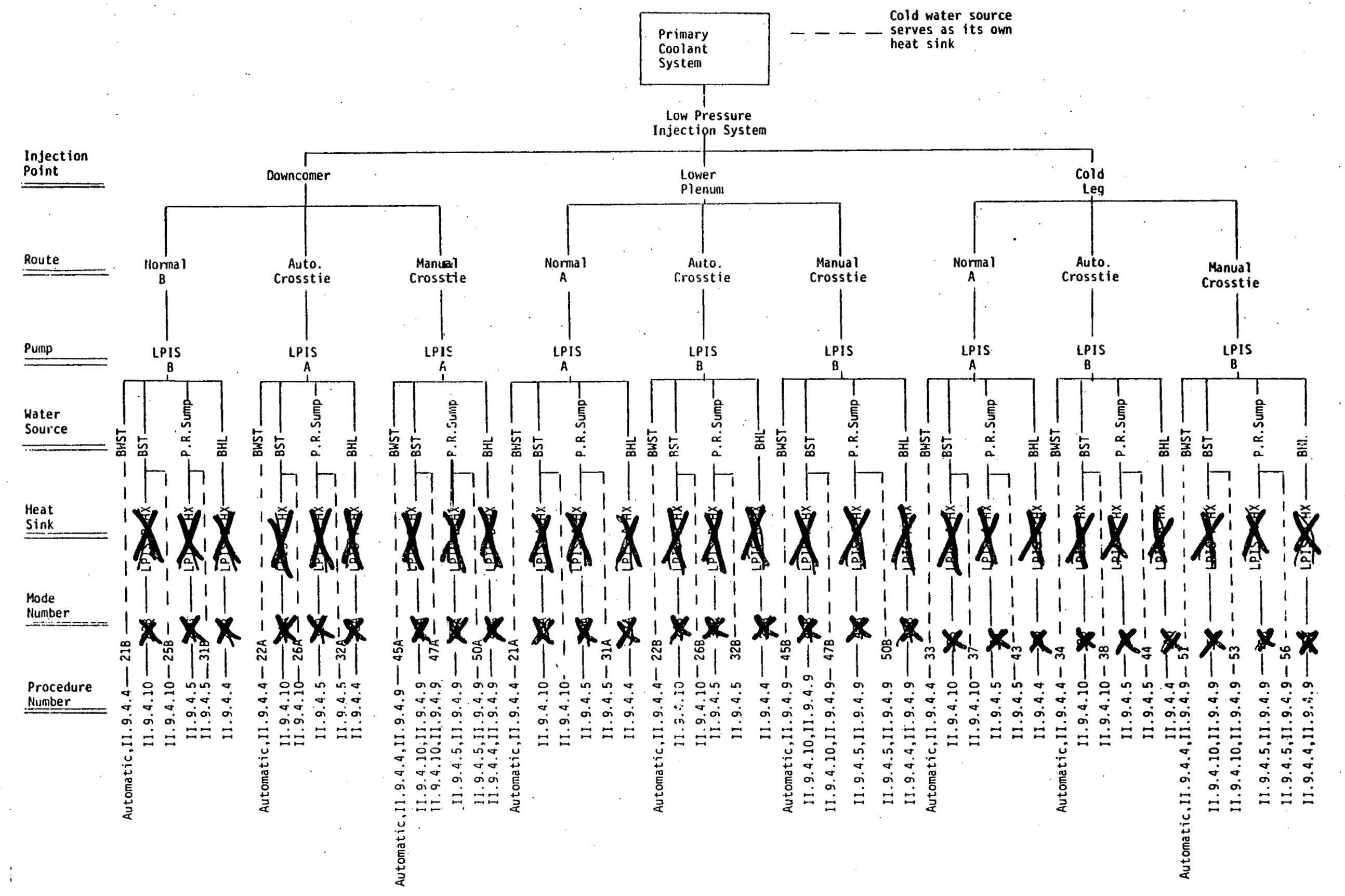




\section{TABLE 1. DIAGNOSIS OF COMPONENT STATUS}

\begin{tabular}{lllll}
\hline $\begin{array}{c}\text { Component } \\
\text { Type }\end{array}$ & $\begin{array}{c}\text { Failure } \\
\text { Mode }\end{array}$ & & Primary Indication & Secondary Indication \\
${$\cline { 1 - 1 }$} }$ & Off & & Status indicator & No out let flow \\
\hline Tank & Empty & Level indicator & \\
\hline
\end{tabular}

Rupture

Pressure $=0$

Level $=0$

\begin{tabular}{lll}
\hline $\begin{array}{l}\text { Control Shut } \\
\text { Valve }\end{array}$ & Position indicator No flow downstream \\
\hline
\end{tabular}

Open (Loss of . Position indicator Pressure $=0$

route integrity)

\begin{tabular}{lll}
\hline Check & Stuck & Reverse flow \\
Valve & Open & Upstream pressure \\
& increases \\
& Downstream pressure \\
decreases
\end{tabular}

Stuck

Shut.

No flow downstream

\begin{tabular}{lll}
\hline Heat & Loss of & Loss of secondary flow \\
Exchanger Heat Removal & Temperature gradient \\
& $=0$
\end{tabular}

Manual

Valve

Shut

Visual inspection

No flow downstream

Open (Loss of

route integrity Visual inspection Pressure $=0$ 
TABLE 1. DIAGNOSIS OF COMPONENT STATUS (Continued)

\begin{tabular}{|c|c|c|c|}
\hline $\begin{array}{l}\text { Component } \\
\text { Type }\end{array}$ & $\begin{array}{l}\text { Failure } \\
\text { Mode }\end{array}$ & Primary Indication & Secondary Indication \\
\hline \multirow[t]{2}{*}{ ipe } & Ruptured & & $\begin{array}{l}\text { Pressure }=0 \\
\text { Low flow downstream } \\
\text { Excess flow upstream }\end{array}$ \\
\hline & Blocked & & No outlet flow \\
\hline
\end{tabular}


TABLE 2. DIAGNOSIS OF REACTOR VESSEL STATUS

\begin{tabular}{lll} 
Malfunction \\
$\begin{array}{l}\text { Fuel } \\
\text { Uncovered }\end{array}$ & $\begin{array}{c}\text { Primary } \\
\text { Indicator } \\
\text { Level indication }\end{array}$ & $\begin{array}{c}\text { Secondary } \\
\text { Indicator }\end{array}$ \\
\hline Inadequate subcooling \\
\hline $\begin{array}{l}\text { Clad } \\
\text { Rupture }\end{array}$ & Pressure decrease & Level decrease \\
\hline $\begin{array}{l}\text { Inadequate } \\
\text { Heat Removal }\end{array}$ & Excess radiation & \\
\hline
\end{tabular}


used to determine the status of the reactor vessel. Table 3 lists the symptoms of various failures which can degrade the performance of a cooling mode. The instruments used to determine these parameters are listed in Appendix E. The diagnostic tables will be used in Section 3.6 to diagnose a hypothetical accident.

The diagnosis of system malfunctions is a complex process and can rarely be accomplished with complete confidence. For example, the symptoms listed in Table 3 represent, an ideal situation where each cooling mode is fully instrumented. Reality dictates that cooling modes cannot always be fully instrumented (see Appendix E). In addition, in some cases, extraneous symptoms will be present, or expected symptoms may be absent due to instrument failure or other causes. All these factors complicate the diagnosis of cooling mode malfunctions. In many cases, a unique diagnosis will not be possible, but it may be possible to narrow the possible causes to such an extent that the exact diagnosis can be quickly verified by field tests.

Much theoretical work has been done concerning diagnosis of malfunctions. based on available symptoms. The medical profession has been particularly active in this field. $29,30,31$ The application of these concepts to diagnosis of failures in nuclear reactor facilities is just beginning.

\subsection{Operator Displays}

Following the evaluation of the response trees by the computer, information concerning system status and preferred course of action musl be communicated to the operator. Three types of display types can be used. The first is a system schematic showing the availability of various components and the preferred cooling mode (Figure 24). Available components will te shown in green, unavailable components in red, and the preferred cooling mode will be highlighted with blue. The second display type is a marked-up response tree which shows which elements are unavailable and why the chosen cooling mode was selected. (Figure 25). The third display type is used to display information about problems within a cooling mode or in the reactor vessel itself (Figure 26). The upper right corner of this display will be used to display relevant symptoms which have been detected. 


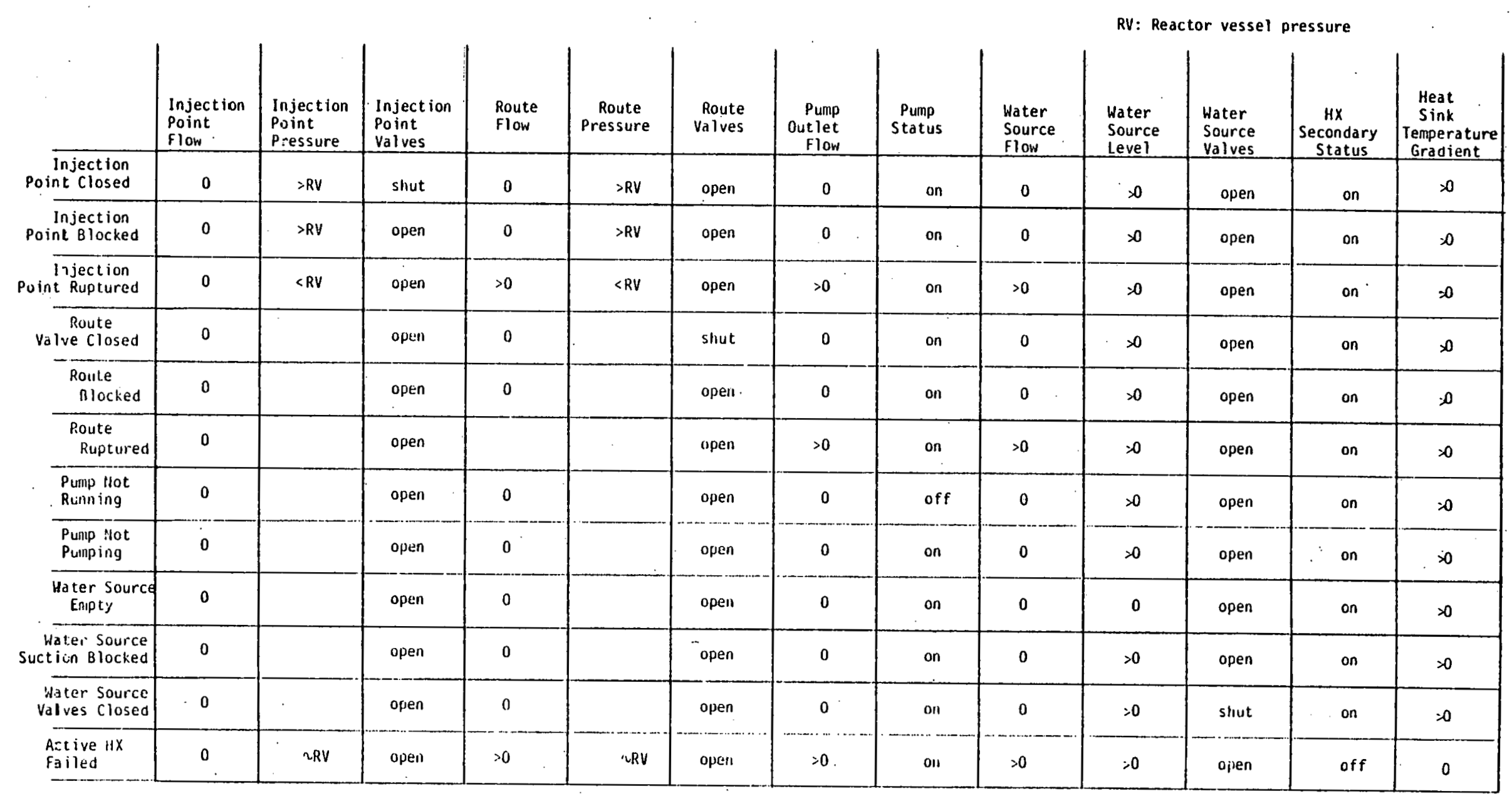

Table 3. Diagrosis of Cooling Mode Status 
Unavailable component

Available component

Figure 24. System schematic displáy

HH Unavailable component Recommended Cooling Mode

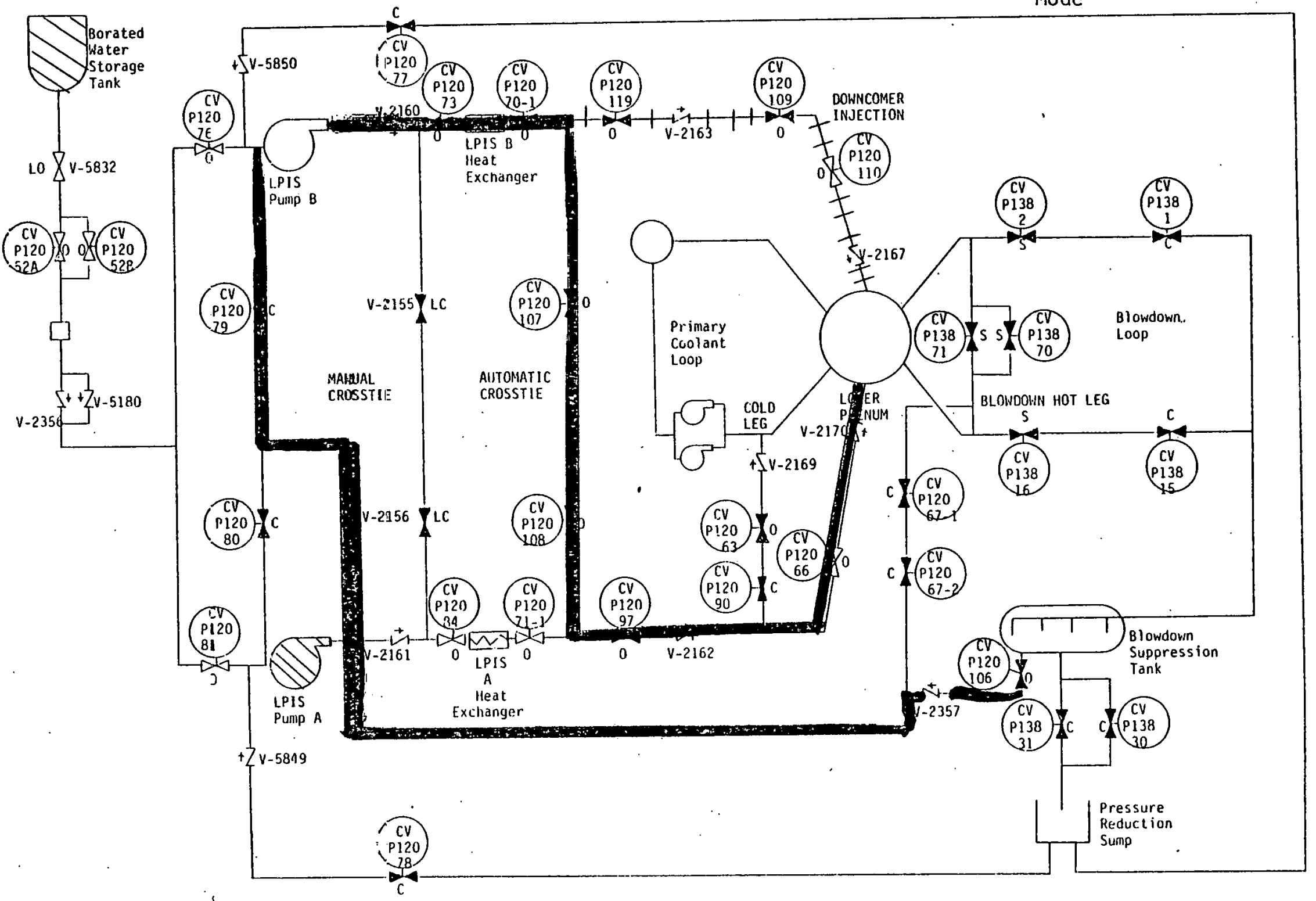


Figure 25. Response tree display
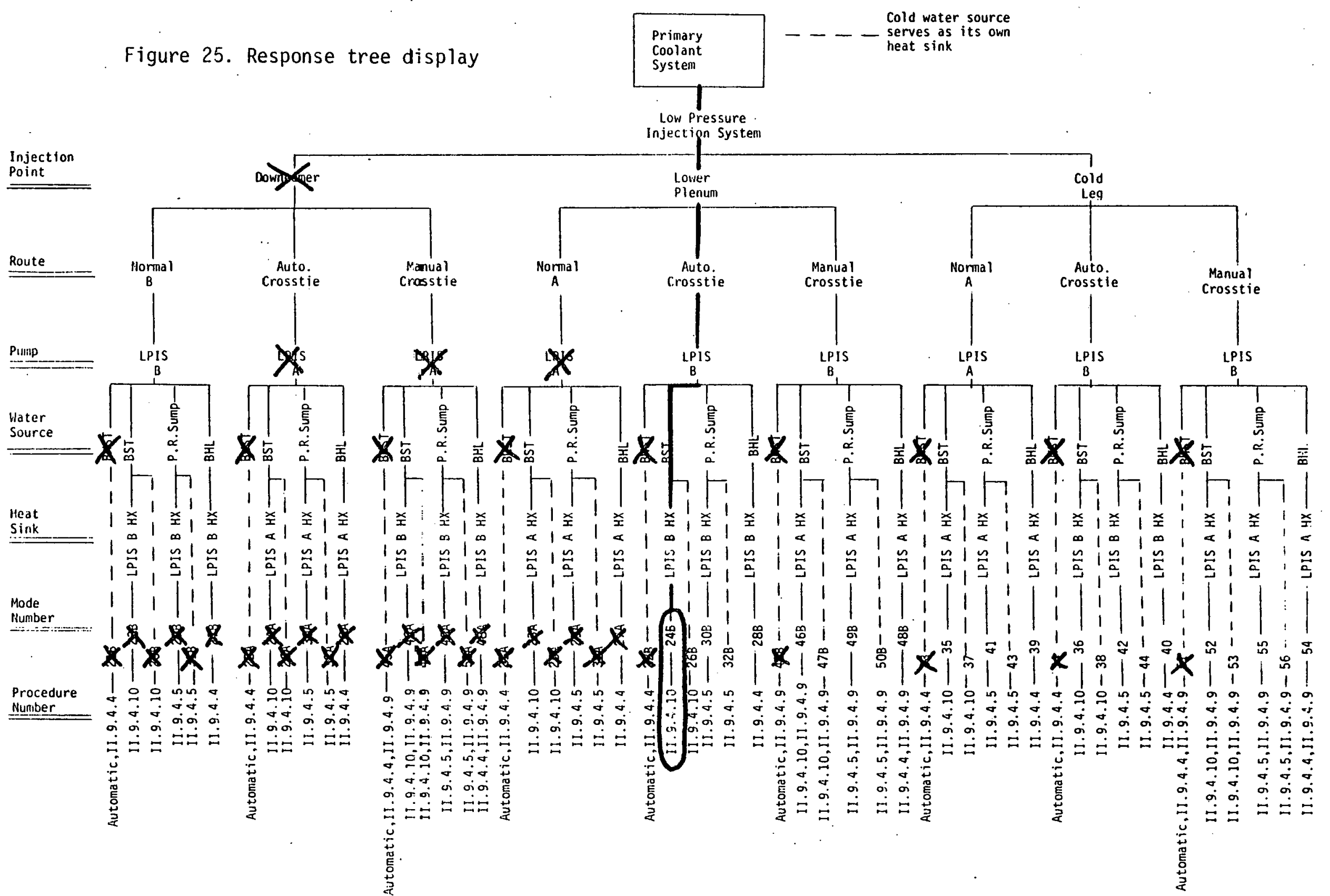
Figure 26. Display for diagnosis of component failures

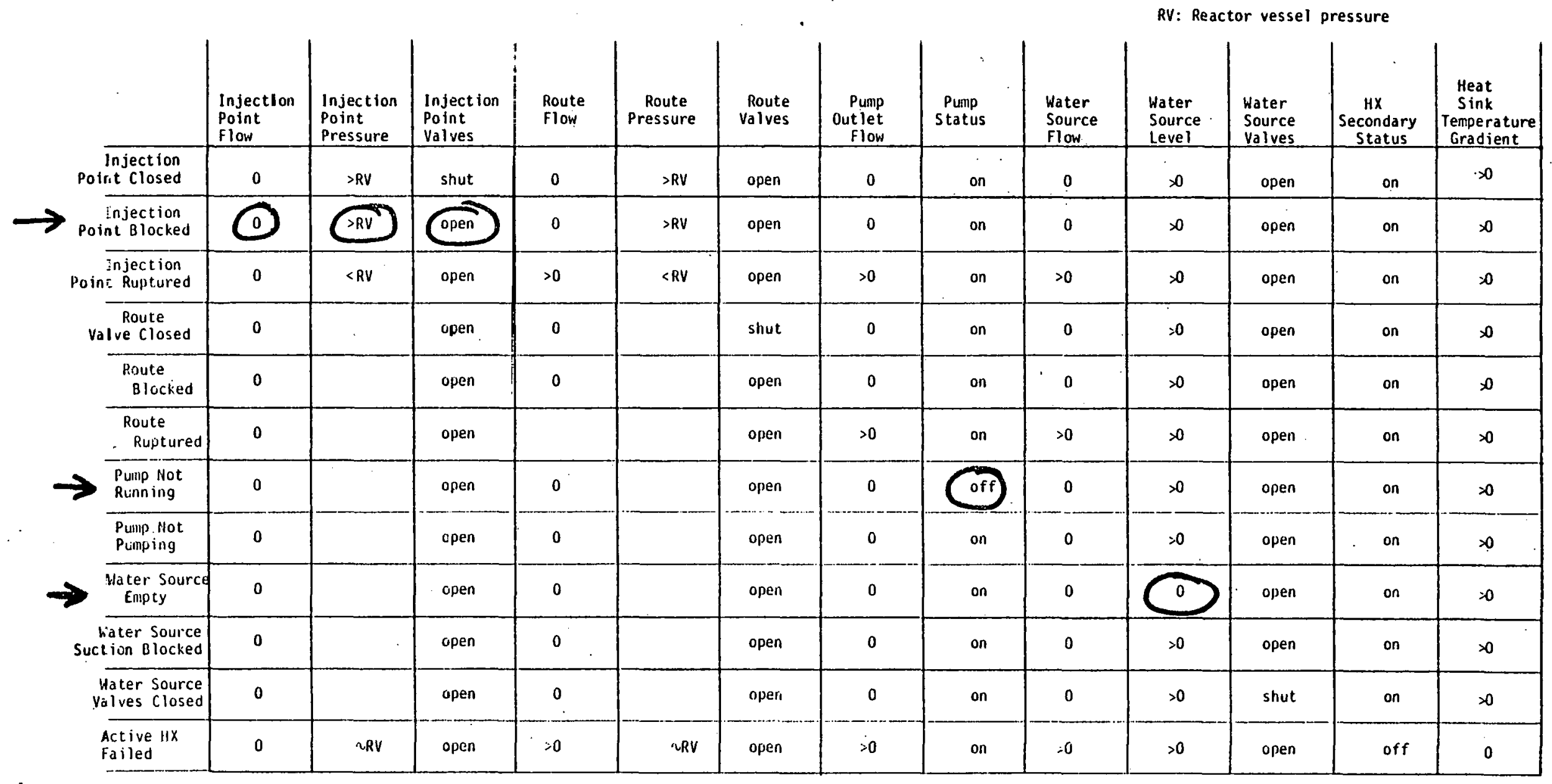


When utilizing any type of computer assisted diagnostic system, it is very important for the operator to know why a particular diagnos is and response have been selected. For this reason the displays have been designed to show him the logic by which the computer has evaluated the accident. The operator can then evaluate the computer's decision based on his own knowledge. and override the computer's recommendation when desired.

\subsection{Procedure for Detection; Diagnosis; and-Treatment of-Emergeney-Eonditions}

The flowchart for the functional analysis of detection, diagnosis, and treatment of an emergency condition has been modified to include the use of the response tree and its associated displays (Figure 27). The steps illustrated in the figure are as follows. The event considered in this process is one which disables or threatens the cooling mode (primary and secondary systems) being used during normal power operation.

1. Monitor plant parameters. Plant parameters including reactor vessel parameters and those associated with the primary-main feedwater cooling mode are monitored. These parameters are compared with the acceptable values for the current mode of operation.

2. If any parameters are outside their expected bounds, a complete set of relevant parameters is gathered.

3. The parameters are compared with the diagnostic tables for the current mode of operation.

4. A list of possible causes is extracted from the diagnostic tables.

5. The response trees are evaluated using currently known system status and the potential causes determined in step 4 . 


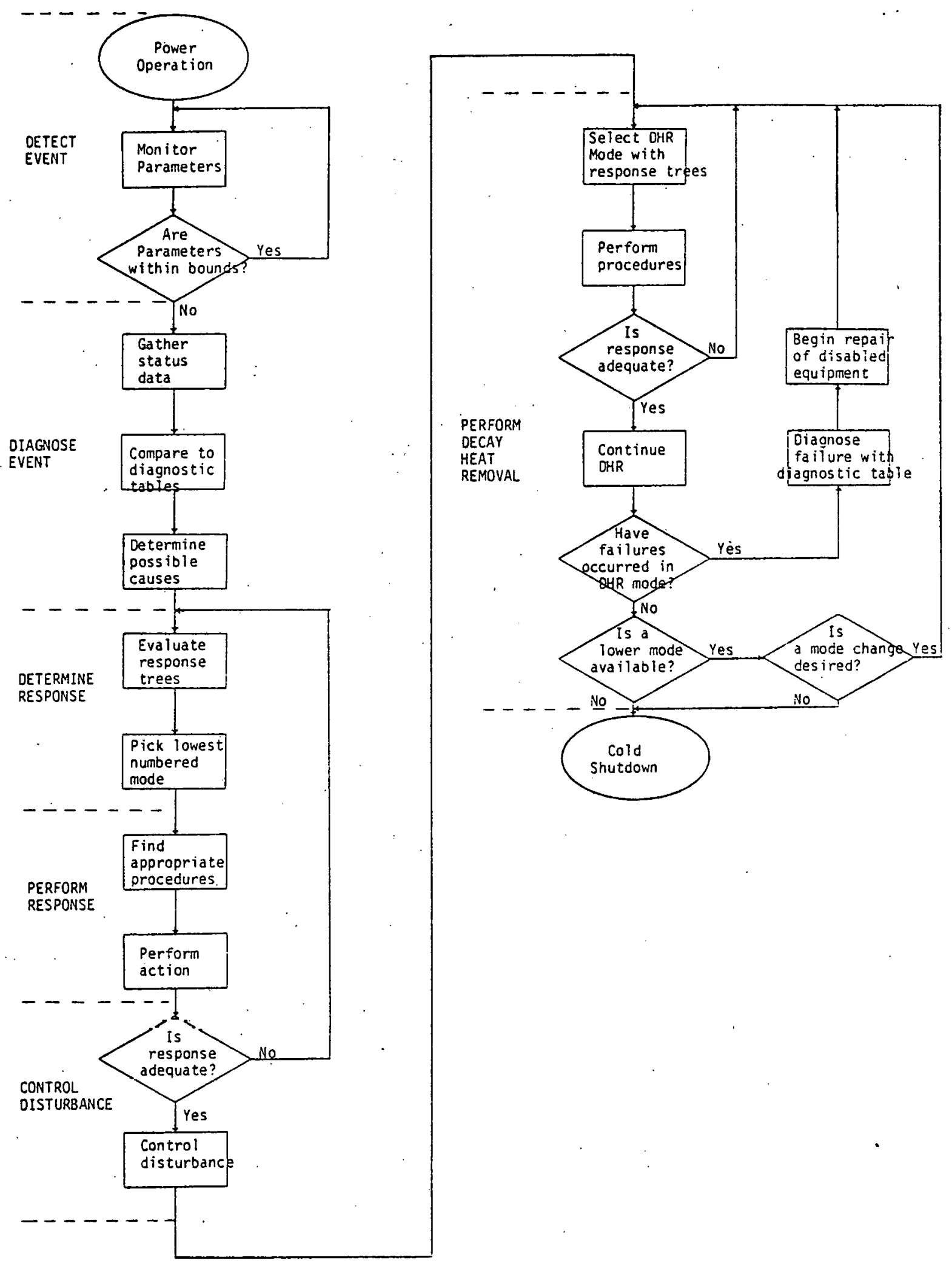

Figure 27. Procedure for detection, diagnosis, and treatment of emergency conditions 
6. The lowest numbered available mode which is suitable for current plant conditions is selected from the response trees.

7. The appropriate procedures for the chosen mode are referenced.

8. The actions needed to implement the mode are performed. If the response of the system is not adequate, return to Step 2 .

9. When the initial disturbance has been controlled, evaluate the response trees and select a decay heat removal mode.

10. Perform the procedures to implement the DHR mode. If the response of the system is not adequate, return to Step 10 .

11. Continue decay heat removal.

12. If further failures occur which endanger the cooling mode, use the diagnostic tables to determine the cause and return to step 9. Begin repair of failed components.

13. As components are repaired, evaluate the desirability of changing to a lower numbered cooling mode. If a change is desired, return to Step 9.

14. Continue decay heat removal until cold shutdown is reached.

These steps provide a complete plan for diagnosing and controlling accidents using response trees and their associated diagnostic tables. The maintenance of an operable cooling mode and the substitution of another mode when a malfunction occurs help guarantee that the reactor fuel is kept cool. and no release of radiation is permitted. The plant computer and graphic displays are utilized to keep the operator informed about the status of important plant systems. 


\section{METHODOLOGY DEMONSTRATION}

\subsection{Hypothetical Accident}

A hypothetical accident has been selected to exercise and test the use of response trees for detecting, diagnosing, and treating emergency conditions. In this section, the accident will be described in terms of the sequence of events. In Section 4.2 , the accident will be described in terms of the symptoms from an operator's point of view and the response trees will be used to diagnose the sequence of events and select the proper responses. The accident progresses in eight phases as follows:

\subsubsection{Phase 1.}

A small break Loss of Coolant Accident (LOCA) occurs simultaneously with a loss of commercial power and instrument air.

\subsubsection{Phase 2.}

HPIS Pump A fails to start.

\subsubsection{Phase 3.}

Instrument air is regained.

4.1.4. Phasp 4.

The accumulators discharge and reduce the primary system pressure. The LPIS pumps start automatically.

\section{1 .5 Phase 5.}

The Borated Water Storage Tank (BWST) is empty. 


\subsubsection{Phase 6.}

A blockage occurs in the downcomer injection point.

\subsubsection{Phase 7.}

Vital Power $A$ is lost.

\subsubsection{Phase 8.}

A valve in the LPIS automatic crosstie line fails shut.

\subsection{Diagnostic System Performance}

\subsubsection{Phase One.}

The symptoms received by the operator are: (1) loss of commercial power alarm, (2) low instrument air pressure alarm, and (3) decreasing reactor vesse 1 pressure. The computer receives these symptoms and displays them to the operator (Figure 28). The response trees are evaluated and Modes $6 A$ and $6 \mathrm{~B}$ are recommended (Figure 29). These c00ling modes use the normal HPIS injection routes utilizing water from the Borated Water Storage Tank. The schematic displays show the recommended cooling modes (Figure 30). The High Pressure Injection system pumps start automatically. The operator begins to monitor their operation and reactor vessel conditions.

\subsubsection{Phase Two.}

The operator notes that HPIS Pump A has failed to start. No pump outlet flow is detected. The computer evaluates the situation and updates the displays (Figures $31,32,33$ ). Mode $6 \mathrm{~B}$, injection to the downcomer using HPIS pump $B$, is continued. 
Figure 28. Phase 1 diagnostic table

LOSS OF COMMERCIAL POWER

LOW INSTRUMENT AIR PRESSURE

LOW REACTOR VESSEL PRESSURE

\begin{tabular}{|c|c|c|c|c|c|c|c|c|c|c|c|c|c|}
\hline \multirow[t]{2}{*}{. } & \multirow[b]{2}{*}{$\begin{array}{l}\text { Injection } \\
\text { Point } \\
\text { Flow }\end{array}$} & \multirow[b]{2}{*}{$\begin{array}{l}\text { Injection } \\
\text { Point } \\
\text { Pressure } \\
\end{array}$} & \multirow[b]{2}{*}{$\begin{array}{l}\text { Injection } \\
\text { Point } \\
\text { Valves } \\
\end{array}$} & \multirow[b]{2}{*}{$\begin{array}{l}\text { Route } \\
\text { Flow }\end{array}$} & \multirow[b]{2}{*}{$\begin{array}{c}\text { Route } \\
\text { Pressure }\end{array}$} & \multirow[b]{2}{*}{$\begin{array}{l}\text { Route } \\
\text { Valves }\end{array}$} & \multirow[b]{2}{*}{$\begin{array}{r}\text { Pump } \\
\text { Outlet } \\
\text { Flow } \\
\end{array}$} & \multirow[b]{2}{*}{$\begin{array}{l}\text { Pump } \\
\text { Status }\end{array}$} & \multicolumn{5}{|c|}{ RV: Reactor vessel pressure } \\
\hline & & & & & & & & & $\begin{array}{l}\text { Water } \\
\text { Source } \\
\text { flow } \\
\end{array}$ & $\begin{array}{l}\text { Water } \\
\text { Source } \\
\text { Level }\end{array}$ & $\begin{array}{l}\text { Water } \\
\text { Source } \\
\text { Valves } \\
\end{array}$ & $\begin{array}{c}\text { HX } \\
\text { Secondary } \\
\text { Status } \\
\end{array}$ & $\begin{array}{c}\text { Heat } \\
\text { Sink } \\
\text { Temperature } \\
\text { Gradient } \\
\end{array}$ \\
\hline $\begin{array}{r}\text { Injection } \\
\text { Point Closed }\end{array}$ & 0 & $>R V$ & shut & 0 & $>R V$ & open & 0 & on & 0 & $=0$ & open & on & $=0$ \\
\hline $\begin{array}{c}\text { Iajection } \\
\text { Point Blocked }\end{array}$ & 0 & $>R V$ & open & 0 & $>R V$ & open & 0 & on & 0 & $\infty$ & open & on & $\infty$ \\
\hline $\begin{array}{l}\text { Injection } \\
\text { Point Ruptured }\end{array}$ & 0 & $<R V$ & open & $>0$ & $<R V$ & open & $>0$ & on & $>0$ & $=0$ & open & on & $>0$ \\
\hline $\begin{array}{c}\text { Route } \\
\text { Valve Closed }\end{array}$ & 0 & & opien & 0 & & shut & 0 & on & 0 & $>0$ & open & on & $0_{0}$ \\
\hline $\begin{array}{l}\text { Route } \\
\text { Blocked }\end{array}$ & 0 & & opren & 0 & & open & 0 & on & 0 & $>0$ & open & on & $\infty$ \\
\hline $\begin{array}{l}\text { Route } \\
\text { Ruptured }\end{array}$ & 0 & & open & & & open & $>0$ & on & $>0$ & $>0$ & open & on & $>0$ \\
\hline $\begin{array}{l}\text { Pump llot } \\
\text { Rinning }\end{array}$ & 0 & & open & 0 & & open & 0 & of $f$ & 0 & $>0$ & open & on & $>_{0}$ \\
\hline $\begin{array}{l}\text { Punp Not } \\
\text { Plimping }\end{array}$ & 0 & & open & 0 & & open & 0 & on & 0 & $>0$ & open & on & $>0$ \\
\hline - Hater Source & 0 & & opien & 0 & & open & 0 & on & 0 & 0 & open & on & $>0$ \\
\hline $\begin{array}{r}\text { Hater Source } \\
\text { Suct :on Blocked }\end{array}$ & 0 & & open & 0 & & open & 0 & on & 0 & $>0$ & open & on & $>0$ \\
\hline $\begin{array}{c}\text { water Source } \\
\text { vaives Closed }\end{array}$ & 0 & & open & 0 & & open & 0 & on & 0 & $>0$ & shut & on & $=0$ \\
\hline $\begin{array}{l}\text { Active } H X \\
\text { Failed }\end{array}$ & 0 & حRV & open & $\cdot 0$ & uRV & open & $>0$ & on & $>0$ & $>0$ & open & off & 0 \\
\hline
\end{tabular}


Figure 29. Phase 1 response tree

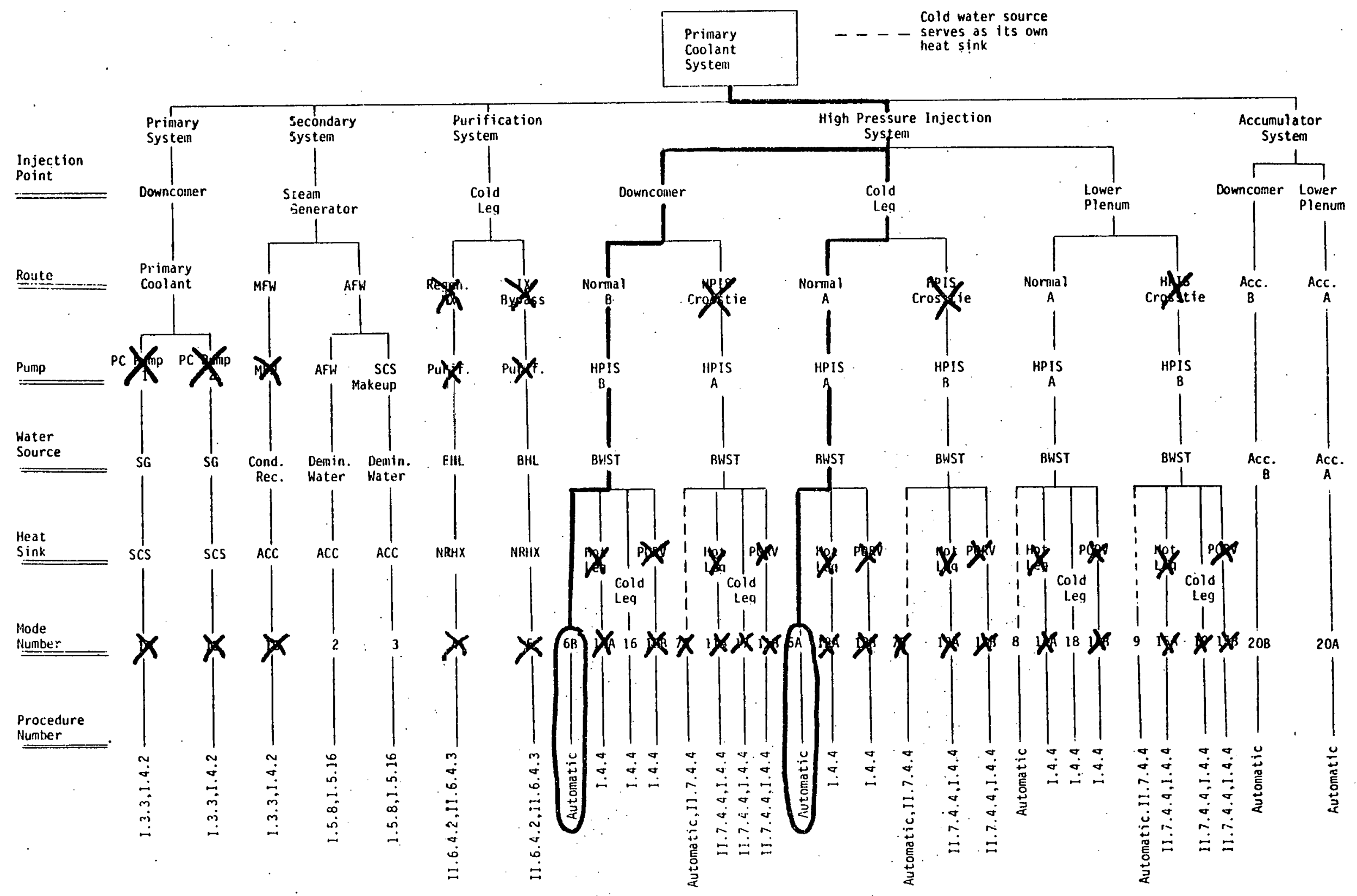


Figure 29. (cont.)

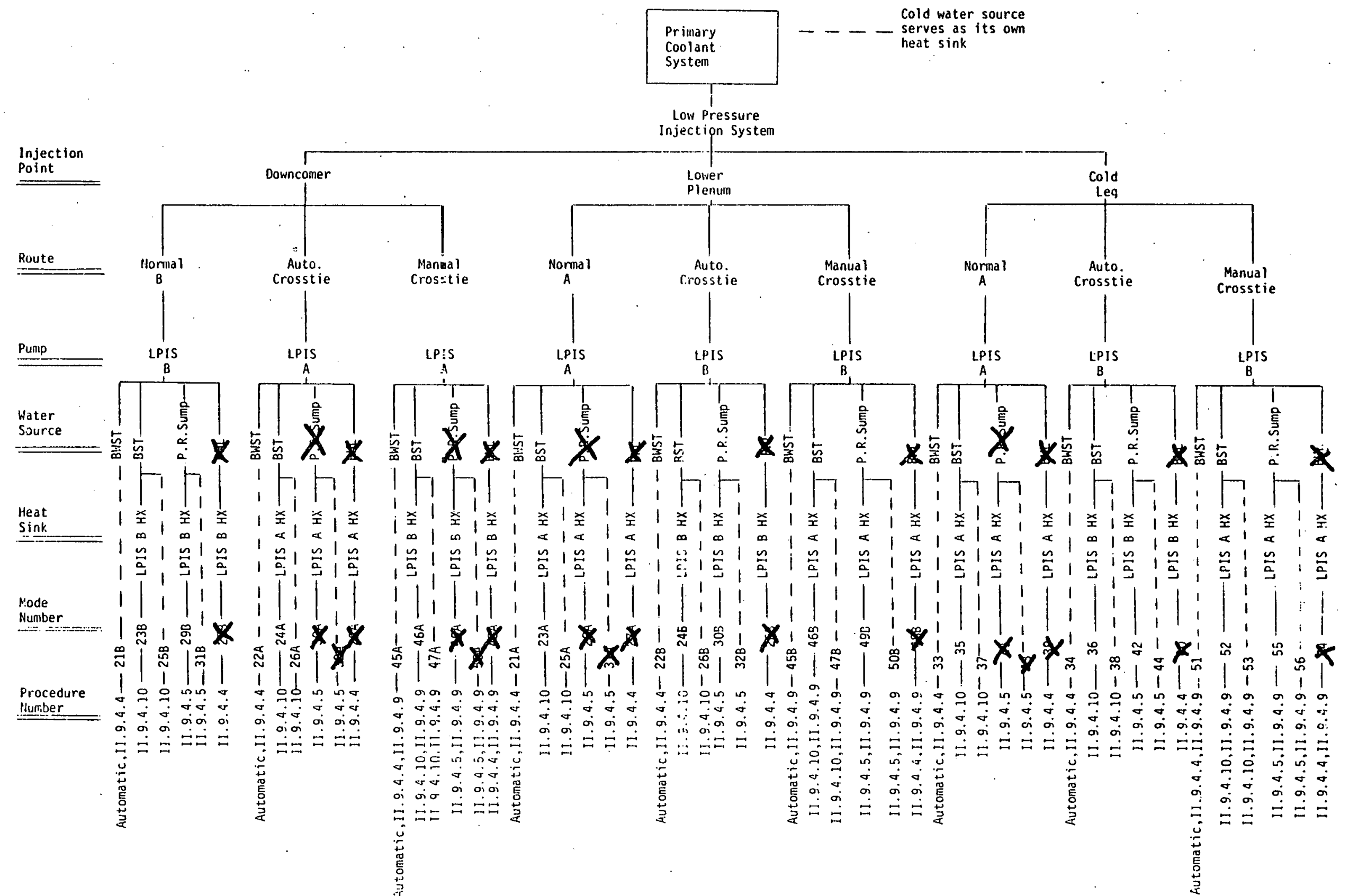


Figure 30. Phase 1 schematic

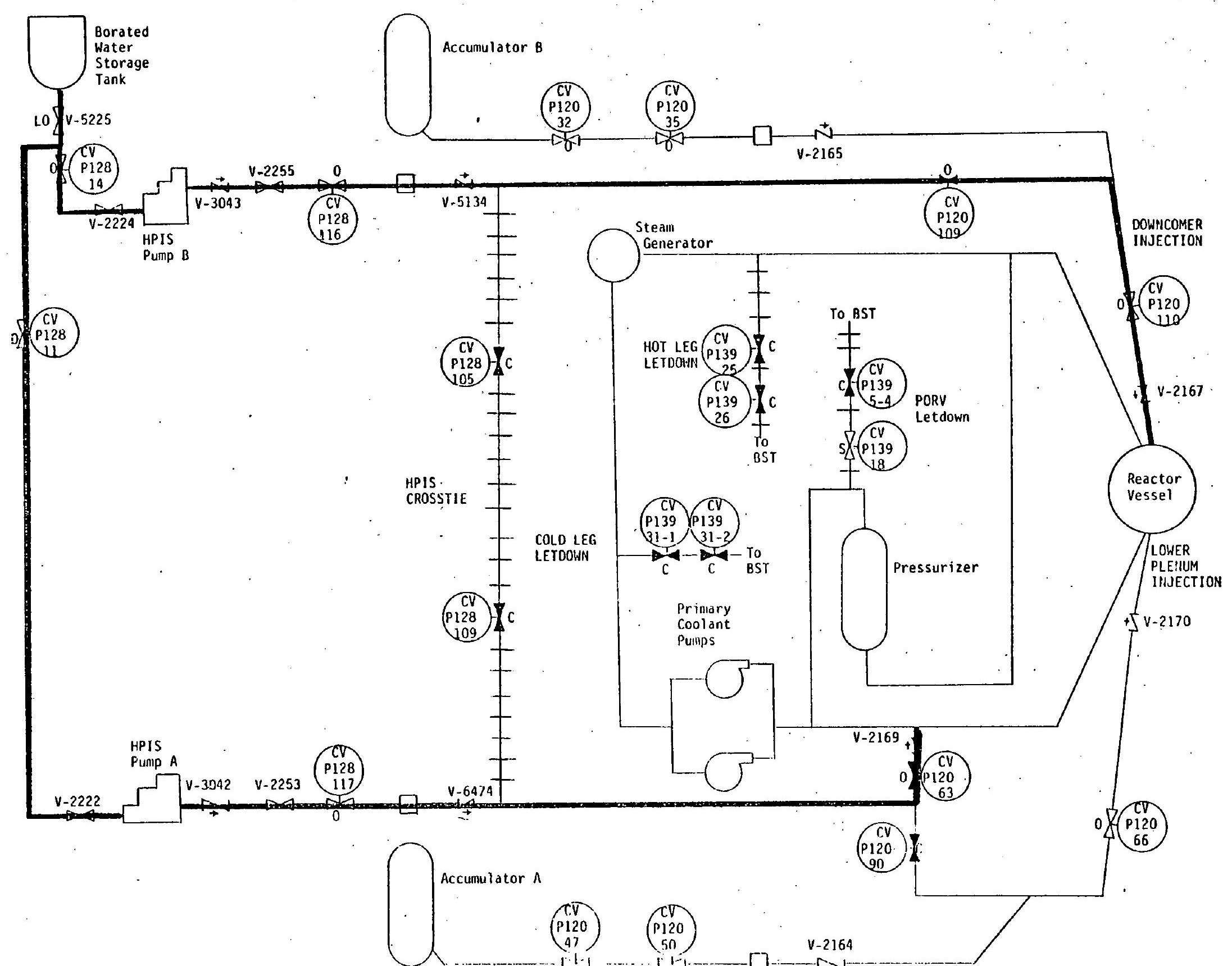


Figure 31. Phase 2 diagnostic table

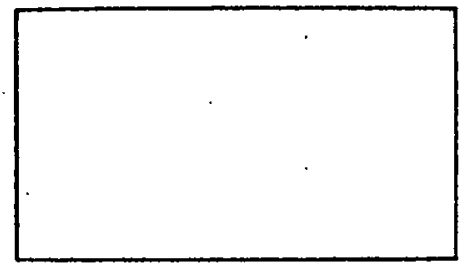

RV: Reactor vessel pressure

\begin{tabular}{|c|c|c|c|c|c|c|c|c|c|c|c|c|c|}
\hline 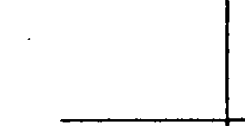 & $\begin{array}{l}\text { Injection } \\
\text { Point } \\
\text { Flow } \\
\end{array}$ & $\begin{array}{l}\text { Injection } \\
\text { Point } \\
\text { Pressure }\end{array}$ & $\begin{array}{l}\text { Injection } \\
\text { Point } \\
\text { Valves }\end{array}$ & $\begin{array}{l}\text { Route } \\
\text { Flow }\end{array}$ & $\begin{array}{c}\text { Route } \\
\text { Pressure }\end{array}$ & $\begin{array}{l}\text { Route } \\
\text { Valves }\end{array}$ & $\begin{array}{r}\text { Punpp } \\
\text { Out let } \\
\text { Flow } \\
\end{array}$ & $\begin{array}{l}\text { Pump } \\
\text { Status }\end{array}$ & $\begin{array}{l}\text { Water } \\
\text { Source } \\
\text { Flow }\end{array}$ & $\begin{array}{l}\text { Water } \\
\text { Source } \\
\text { Level } \\
\end{array}$ & $\begin{array}{l}\text { Water } \\
\text { Source } \\
\text { Valves } \\
\end{array}$ & $\begin{array}{c}\mathrm{HX} \\
\text { Secondary } \\
\text { Status } \\
\end{array}$ & $\begin{array}{c}\text { Heat } \\
\text { Sink } \\
\text { Temperature } \\
\text { Gradient }\end{array}$ \\
\hline $\begin{array}{l}\text { Injection } \\
\text { Point Closed }\end{array}$ & 0 & $>R V$ & shut & 0 & $>R V$ & open & 0 & on & 0 & $>0$ & open & on & 20 \\
\hline $\begin{array}{c}\text { Injection } \\
\text { Point Blocked }\end{array}$ & 0 & $>R V$ & open & 0 & $>R V$ & open & 0 & on & 0 & $>0$ & open & on & $\varnothing$ \\
\hline $\begin{array}{l}\text { Injection } \\
\text { Point Ruptured }\end{array}$ & 0 & $<R V$ & open & $>0$ & $<R V$ & open & $>0$ & on & $>0$ & $>0$ & open & on & -0 \\
\hline $\begin{array}{c}\text { Route } \\
\text { Valve Closed }\end{array}$ & 0 & & open & 0 & . & shut & 0 & on & 0 & $>0$ & open & on & $\infty$ \\
\hline $\begin{array}{l}\text { Route } \\
\text { Blocked }\end{array}$ & 0 & & open & 0 & . & open & 0 & on & 0 & $>0$ & open & on & $\varnothing 0$ \\
\hline $\begin{array}{l}\text { Route } \\
\text { Ruptured }\end{array}$ & 0 & & open & & & open & $>0$ & on & $>0$ & $>0$ & open & on & $=0$ \\
\hline $\begin{array}{l}\text { Pump Hot } \\
\text { Runn ing }\end{array}$ & 0 & & open & 0 & & open & & & 0 & $=0$ & open & on & $=0$ \\
\hline $\begin{array}{l}\text { Puinp Not } \\
\text { Punping }\end{array}$ & 0 & & open & 0 & . & open & 0 & on & 0 & $>0$ & open & on & $=0$ \\
\hline $\begin{array}{l}\text { Water Source } \\
\text { Enipty } r\end{array}$ & 0 & - & open & 0 & & open & 0 & on & 0 & 0 & open & on & $=0$ \\
\hline $\begin{array}{r}\text { Hater Source } \\
\text { Suction Blocked }\end{array}$ & 0 & & open & 0 & & open & 0 & on & 0 & $>0$ & open & on & $>0$ \\
\hline $\begin{array}{r}\text { Water Source } \\
\text { valves Closed }\end{array}$ & 0 & & open & 0 & & open & 0 & on & 0 & $>0$ & shut & on & $>0$ \\
\hline $\begin{array}{l}\text { Active } \| x \\
\text { =alled }\end{array}$ & 0 & URV & open & $>0$ & حRV & upen & $>0$ & on & $>0$ & $>0$ & open & off & 0 \\
\hline
\end{tabular}


Figure 32. Phase 2 response tree

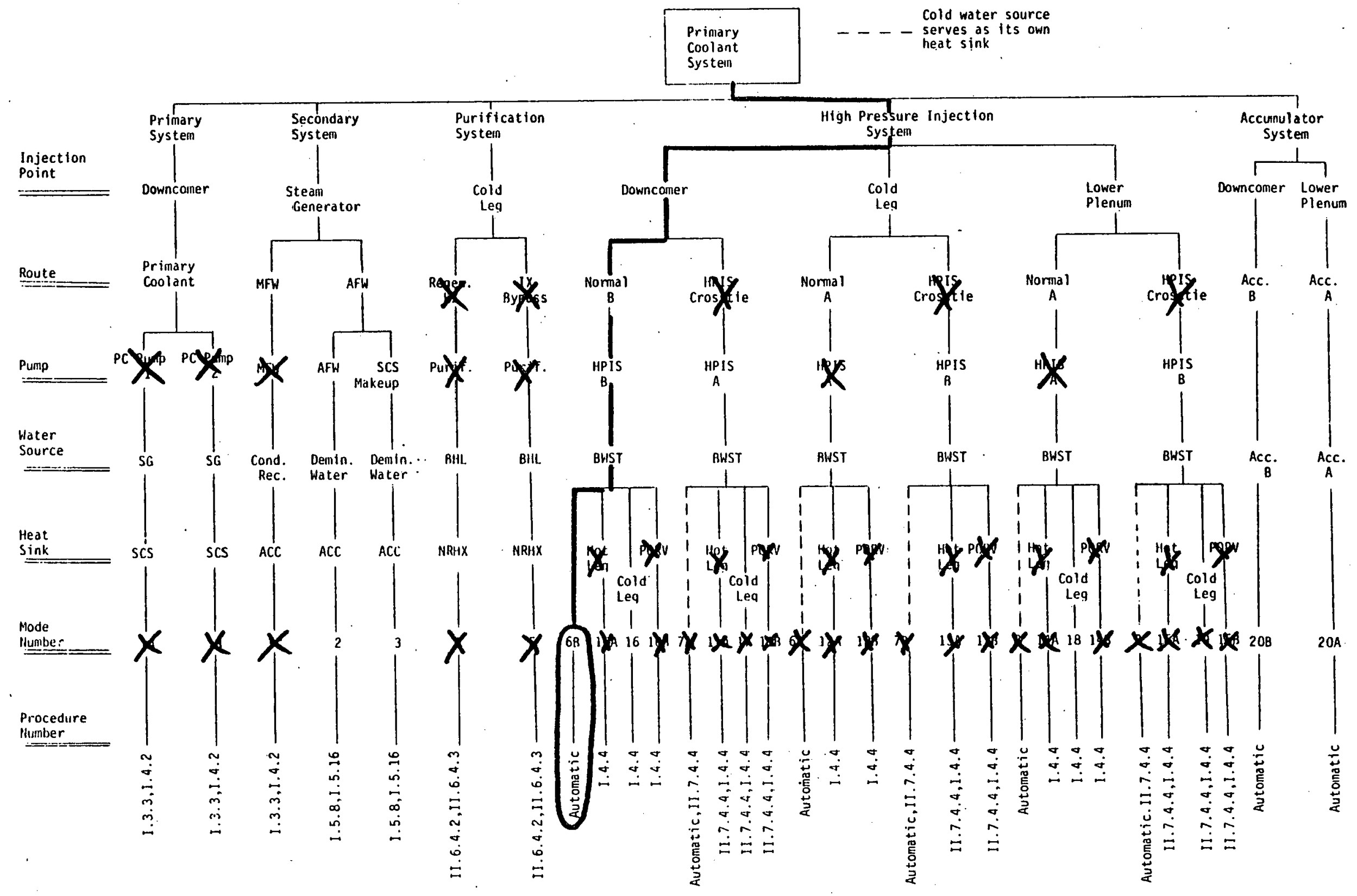


Figure 32. (cont.)

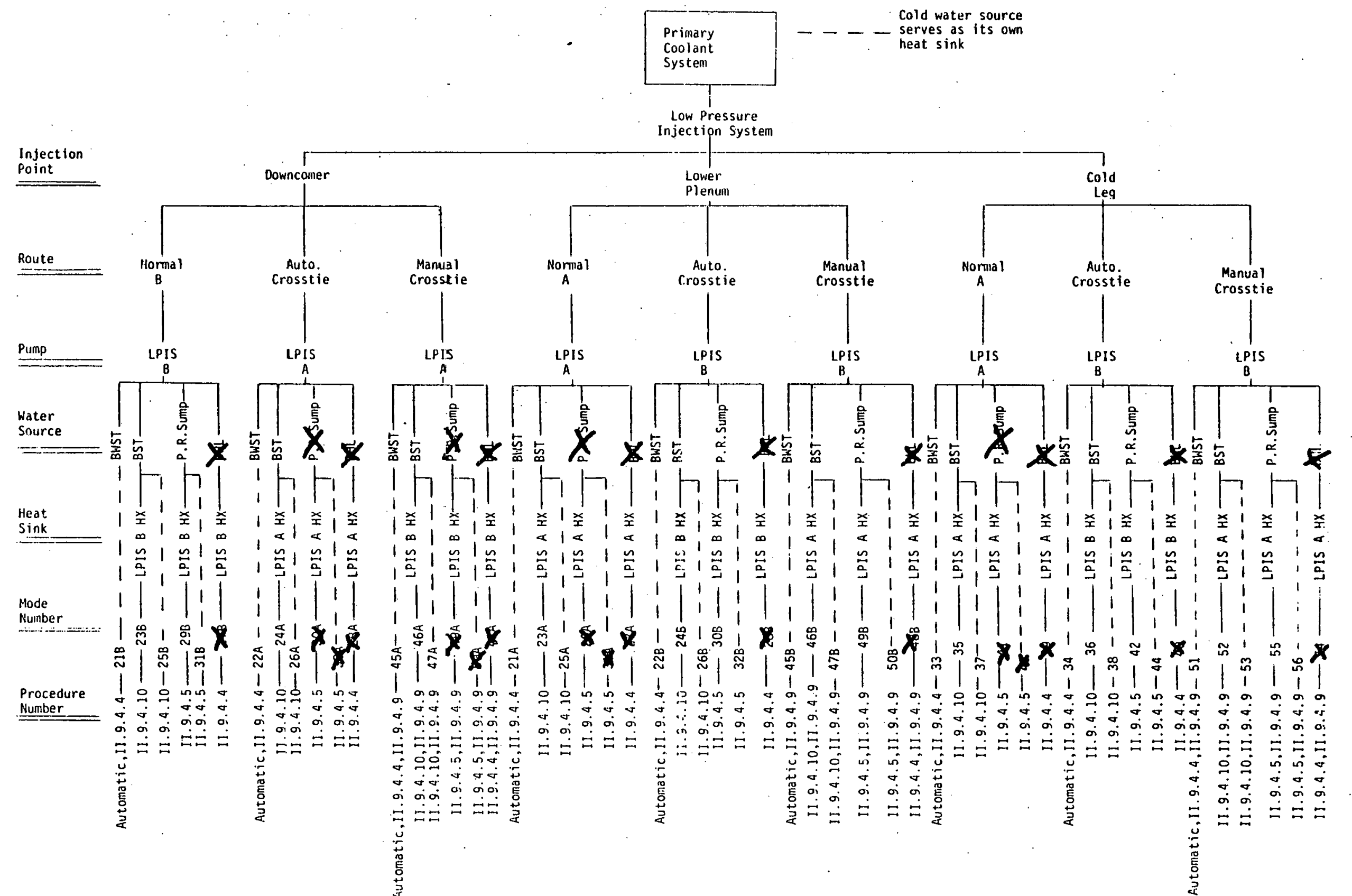


Figure 33. Phas 2 schematic

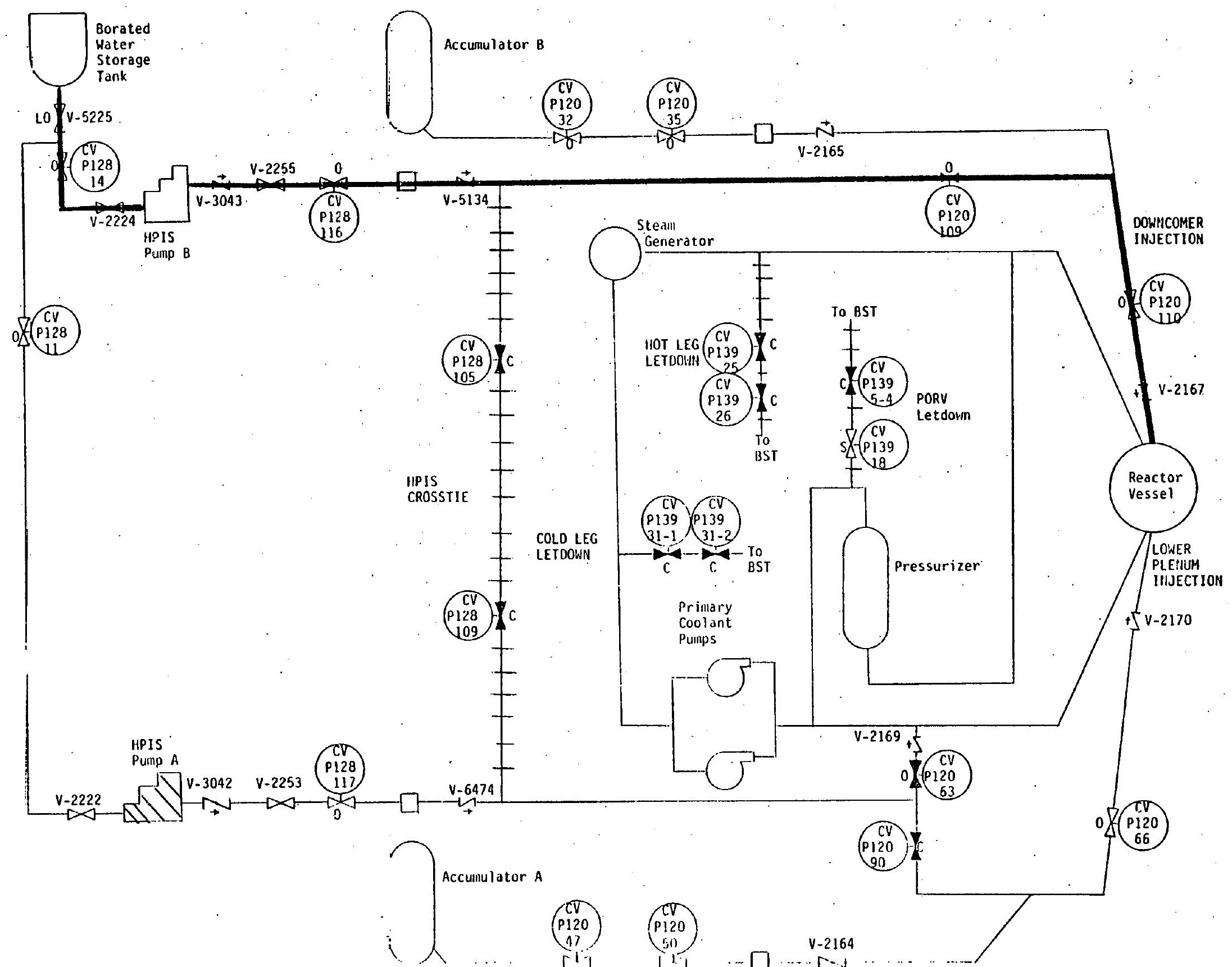




\subsubsection{Phase Three.}

The low instrument air alarm clears. The displays are upcated as shown in Figures 34,35 , and 36 . Mode $6 \mathrm{~B}$ cont inues to operate.

\subsubsection{Phase Four.}

An indication of flow in accumulator injection lines is detected. Reactor vessel pressure begins to decrease. The accumulators are soon empty. Displays are updated as shown in Figures 37, 38, and 39. LPIS Modes 21A and 218 are initiated automatically as the reactor vessel pressure decreases below 190 psi. Both LPIS pumps take suction from the Borated Water Storage Tank. Injection is to the downcomer and lower plenum.

\subsubsection{Phase Five.}

Low level alarm for the Borated Water Storage Tank is received. Displays update as shown in Figures 40,41 , and 42 . The operator switches to Modes 23A

- and 238 by switching LPIS suction to the Blowdown Suppression Tank using Procedure II. 9.4.10.

\subsubsection{Phase Six.}

Symptoms received are: (1) no flow at LPIS Pump B out let and (2) injection point pressure greater than reactor vesse 1 pressure. Displays update as shown in Figures 43,44 , and 45 . Mode $23 \mathrm{~A}$ continues to operate, injecting water into the lower plenum with LPIS Pump $A$.

\subsubsection{Phase Seven.}

A loss of Vital Power $A$ alarm is received. Displays are updated (Figures $46,47,48$ ). LPIS Pump $A$ can no longer be used, so flow is directed through the automatic crosstie, which should be open, using LPIS Pump $B$ (Mode 24B). 
Figure 34. Phase 3 diagnostic table

CLEAR LOW INSTRUMENT AIR PRESSURE ALARM

\begin{tabular}{|c|c|c|c|c|c|c|c|c|c|c|c|c|c|}
\hline . & & & & & & & & & & RV: Re & or vesse & ressure & \\
\hline 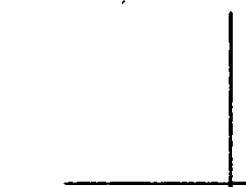 & $\begin{array}{l}\text { Injection } \\
\text { Point } \\
\text { Flow }\end{array}$ & $\begin{array}{l}\text { Injection } \\
\text { Point } \\
\text { Pressure }\end{array}$ & $\begin{array}{l}\text { Injection } \\
\text { Point } \\
\text { Valves } \\
\end{array}$ & $\begin{array}{l}\text { Route } \\
\text { Flow }\end{array}$ & $\begin{array}{c}\text { Route } \\
\text { Pressure }\end{array}$ & $\begin{array}{r}\text { Route } \\
\text { Valves }\end{array}$ & $\begin{array}{r}\text { Pump } \\
\text { Outlet } \\
\text { Flow } \\
\end{array}$ & $\begin{array}{c}\text { Pump } \\
\text { Status }\end{array}$ & $\begin{array}{l}\text { Water } \\
\text { Source } \\
\text { Flow } \\
\end{array}$ & $\begin{array}{l}\text { Water } \\
\text { Source } \\
\text { Level }\end{array}$ & $\begin{array}{l}\text { Water } \\
\text { Source } \\
\text { Valves }\end{array}$ & $\begin{array}{c}\mathrm{HX} \\
\text { Secondary } \\
\text { Status }\end{array}$ & $\begin{array}{c}\text { Heat } \\
\text { Sink } \\
\text { Temperature } \\
\text { Gradient }\end{array}$ \\
\hline $\begin{array}{r}\text { Irjection } \\
\text { Point Closed }\end{array}$ & 0 & $>R V$ & shut & 0 & $>R V$ & open & .0 & on & 0 & $=0$ & open & on & $\because 0$ \\
\hline $\begin{array}{c}\text { Injection } \\
\text { Point Blocked }\end{array}$ & 0 & $>R V$ & open & 0 & $>\mathrm{RV}$ & open & 0 & on & 0 & $>0$ & open & on & $=0$ \\
\hline $\begin{array}{c}\text { Injection } \\
\text { Point Ruptured }\end{array}$ & 0 & $<R V$ & open & $>0$ & $<R V$ & open & $>0$ & on & $>0$ & $\succ_{0}$ & open & on & $>0$ \\
\hline $\begin{array}{c}\text { Route } \\
\text { Value Closed }\end{array}$ & 0 & . & open. & 0 & & shut & 0 & on & 0 & $\searrow_{0}$ & open & on & $\infty$ \\
\hline $\begin{array}{l}\text { Route } \\
\text { Blocked }\end{array}$ & 0 & & open & 0 & & open & 0 & on & 0 & $>0$ & open & on & $\infty$ \\
\hline $\begin{array}{l}\text { Route } \\
\text { Rupt tured }\end{array}$ & 0 & & open & . & & open & $>0$ & on & $>0$ & $>0$ & open & on & $>0$ \\
\hline $\begin{array}{l}\text { Pump Hot } \\
\text { Running }\end{array}$ & 0 & & open & 0 & & open & 0 & off & 0 & 20 & open & on & $=0$ \\
\hline $\begin{array}{l}\text { Punip Not } \\
\text { Pumping } \\
\end{array}$ & 0 & & open & 0 & & open & 0 & on & 0 & $=0$ & open & on & $>0$ \\
\hline $\begin{array}{l}\text { Water Source } \\
\text { Enply }\end{array}$ & 0 & & open & 0 & & open & 0 & on & 0 & 0 & open & on & $>0$ \\
\hline $\begin{array}{r}\text { Water Source } \\
\text { Suction B locked }\end{array}$ & 0 & & open & 0 & & open & 0 & on & 0 & $>0$ & open & on & $x_{0}$ \\
\hline $\begin{array}{c}\text { Water Source } \\
\text { valves Closed }\end{array}$ & 0 & & open & 0 & . & open & 0 & on & 0 & $>0$ & shut & on & $>0$ \\
\hline $\begin{array}{l}\text { Active } H X \\
\text { Failed }\end{array}$ & 0 & uRV & open & $>0$ & aRV & open & $>0$ & on & $=0$ & $>0$ & open & of $f$ & 0 \\
\hline
\end{tabular}


Figure 35. Phase 3 response tree

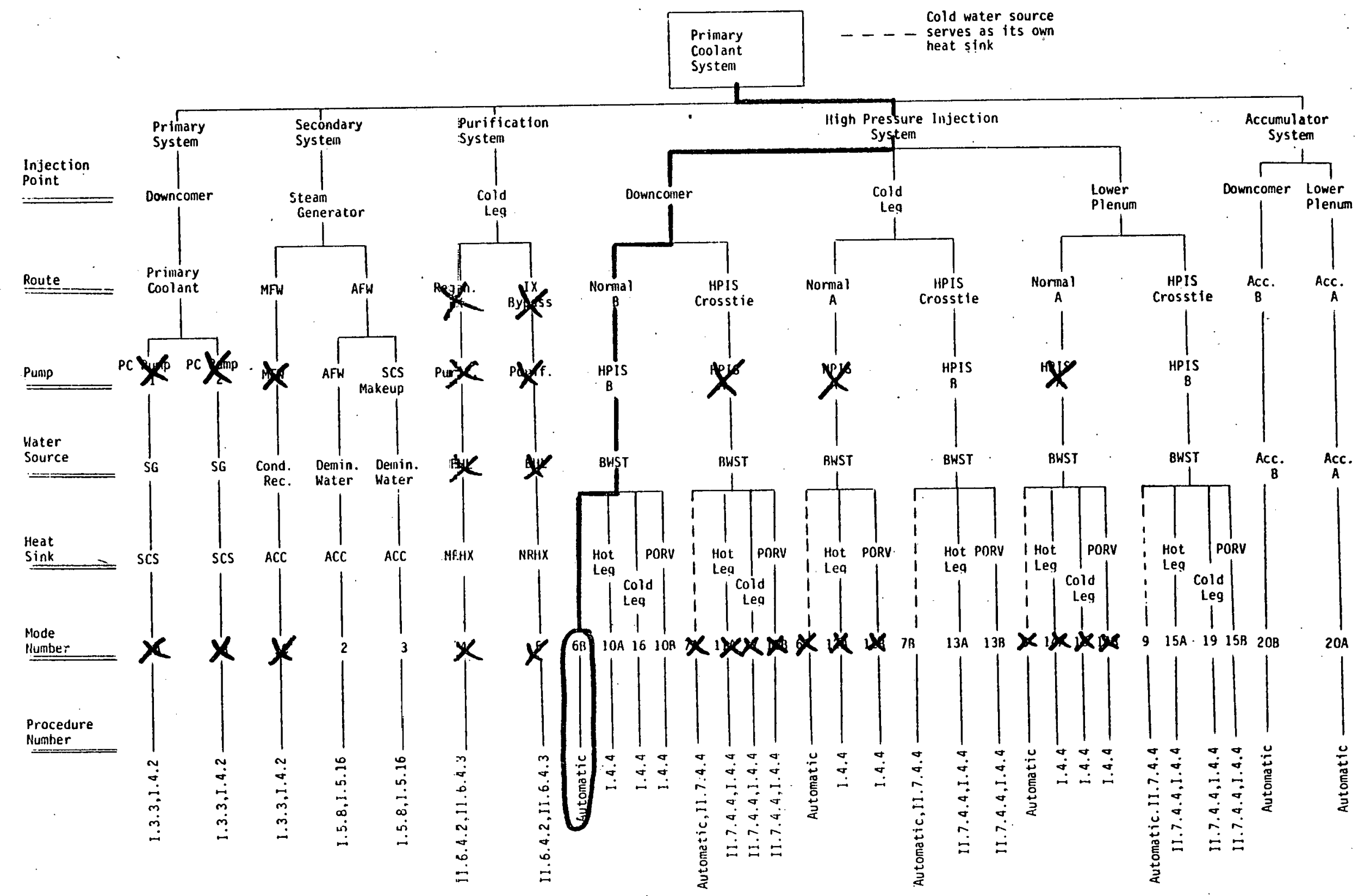


Figure 35. (cont.)

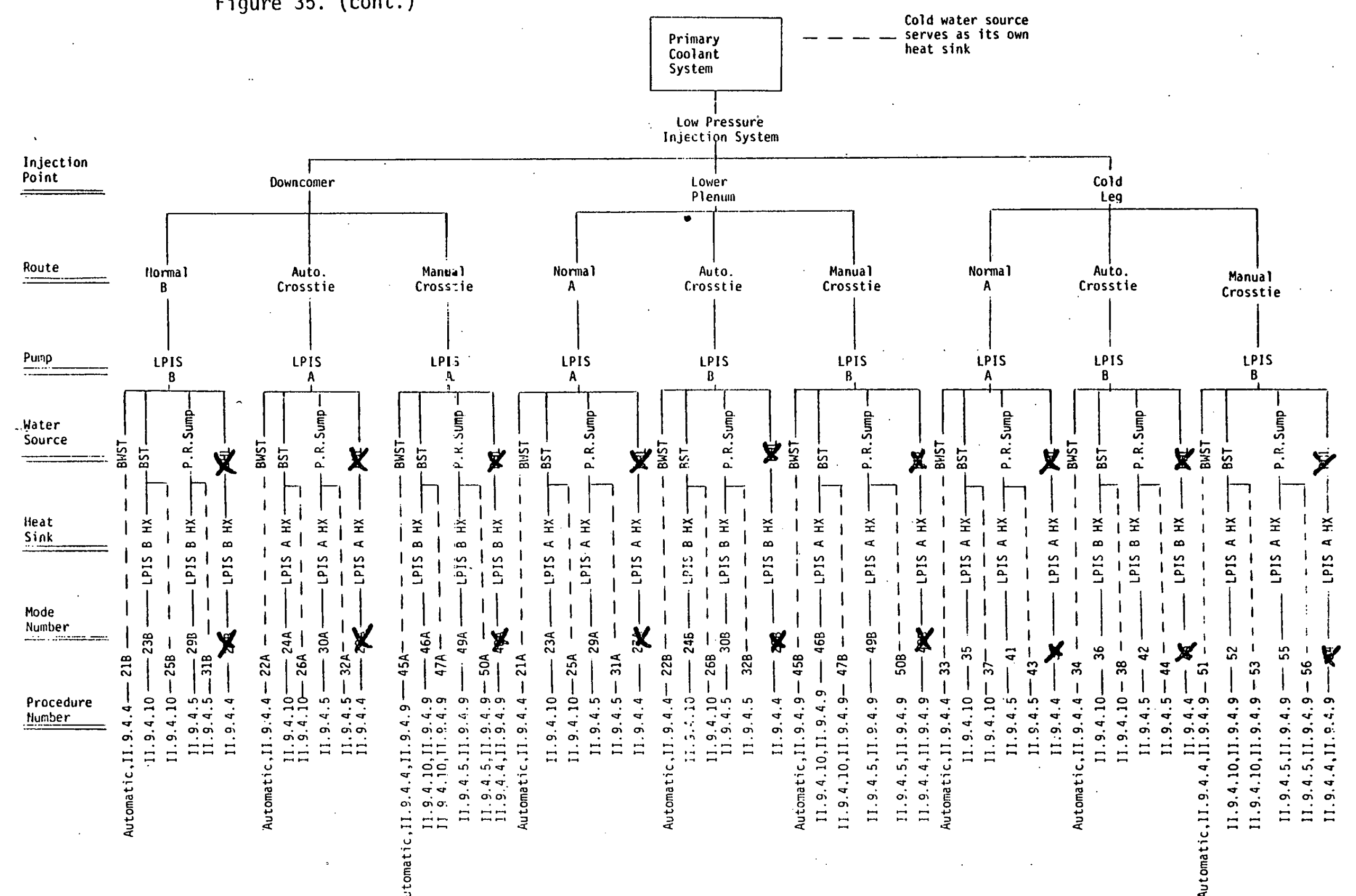


Figure 36 . Phase 3 schematic

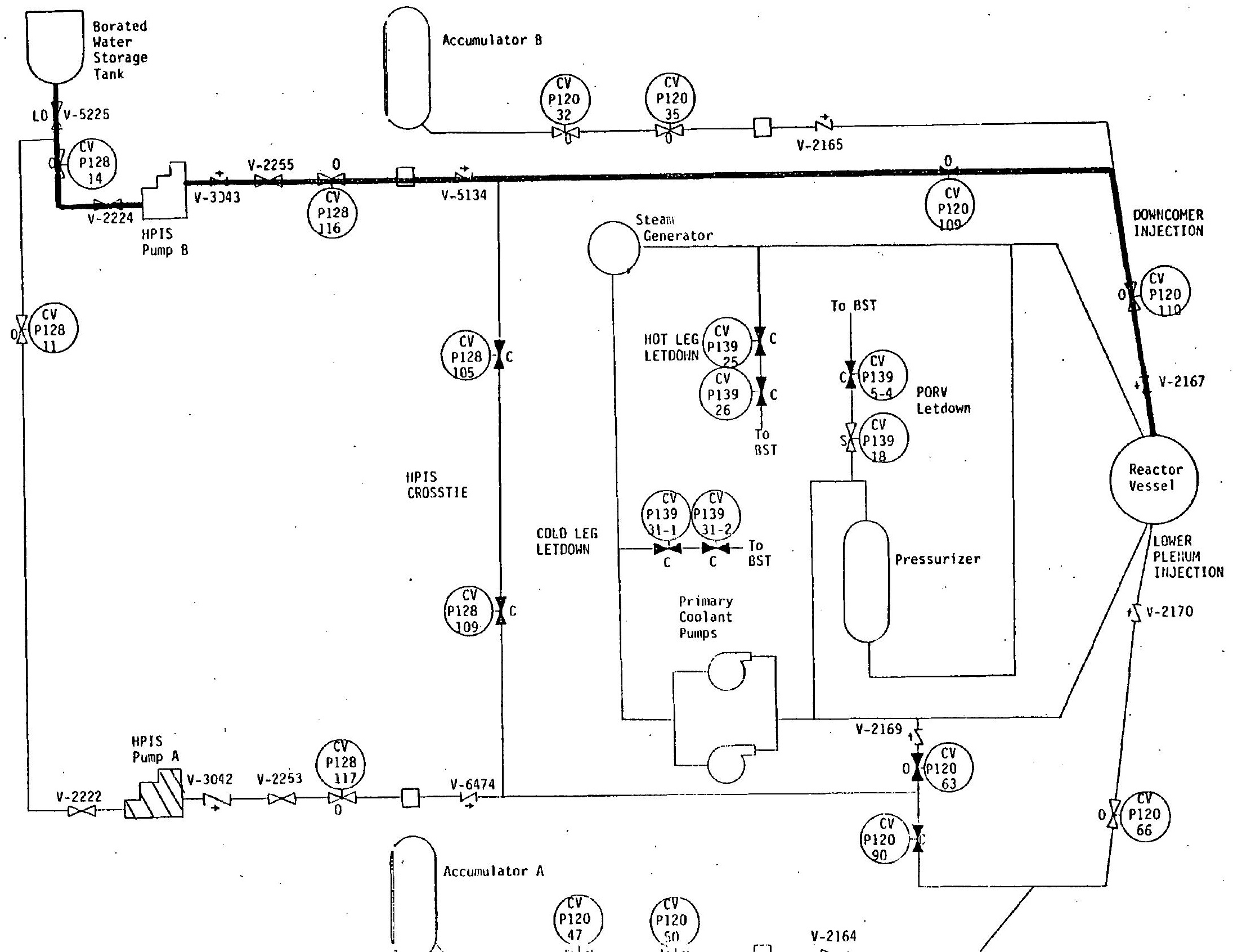


Figure 37 . Phase 4 diagnostic table

ACCUMULATOR FLOW

LOW ACCUMULATOR LEVEL

RV: Reactor vessel pressure

\begin{tabular}{|c|c|c|c|c|c|c|c|c|c|c|c|c|c|}
\hline 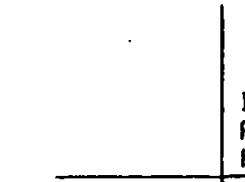 & $\begin{array}{l}\text { Injection } \\
\text { Point } \\
\text { Flow }\end{array}$ & $\begin{array}{l}\text { Injection } \\
\text { Point } \\
\text { Pressure }\end{array}$ & $\begin{array}{l}\text { Injection } \\
\text { Point } \\
\text { Valves }\end{array}$ & $\begin{array}{l}\text { Route } \\
\text { Flow }\end{array}$ & $\begin{array}{c}\text { Route } \\
\text { Pressure }\end{array}$ & $\begin{array}{l}\text { Route } \\
\text { Valves }\end{array}$ & $\begin{array}{r}\text { Punp } \\
\text { Out let } \\
\text { Flow } \\
\end{array}$ & $\begin{array}{l}\text { Pump } \\
\text { Status }\end{array}$ & $\begin{array}{l}\text { Water } \\
\text { Source } \\
\text { Flow } \\
\end{array}$ & $\begin{array}{l}\text { Water } \\
\text { Source } \\
\text { Level } \\
\end{array}$ & $\begin{array}{l}\text { Water } \\
\text { Source } \\
\text { Valves } \\
\end{array}$ & $\begin{array}{c}\mathrm{HX} \\
\begin{array}{c}\mathrm{Secondary} \\
\text { Status }\end{array} \\
\end{array}$ & \begin{tabular}{|c|} 
Heat \\
Sink \\
Temperature \\
Gradient \\
\end{tabular} \\
\hline $\begin{array}{r}\text { Injection } \\
\text { Point Closed }\end{array}$ & 0 & $>R V$ & shut & 0 & $>R V$ & open & 0 & on & 0 & $>0$ & open & on & $>0$ \\
\hline $\begin{array}{c}\text { Injection } \\
\text { Point Blocked }\end{array}$ & 0 & $>R V$ & open & 0 & $>R V$ & open & 0 & on & 0 & $>0$ & open & on & $\infty 0$ \\
\hline $\begin{array}{l}\text { Injection } \\
\text { Point. Ruptured }\end{array}$ & 0 & $<R V$ & open & $>0$ & $<R V$ & open & $>0$ & on & $>0$ & $>0$ & open & on & $>0$ \\
\hline $\begin{array}{c}\text { Route } \\
\text { Valve Closed }\end{array}$ & 0 & & open & 0 & & shut & 0 & on & 0 & $>0$ & open & on & $\varnothing 0$ \\
\hline $\begin{array}{l}\text { Route } \\
\text { Blocked }\end{array}$ & 0 & . & open & 0 & & open' & 0 & on & 0 & $>0$ & open & on & $\varnothing 0$ \\
\hline $\begin{array}{l}\text { Route } \\
\text { Ruptured }\end{array}$ & 0 & & open & & & open & $>0$ & on & $>0$ & $>0$ & open & on & $>0$ \\
\hline $\begin{array}{l}\text { Pump Not } \\
\text { Running }\end{array}$ & 0 & & open & 0 & & open & 0 & off & 0 & $>0$ & open & on & ذ0 \\
\hline $\begin{array}{l}\text { Puilp llot } \\
\text { Plimping }\end{array}$ & 0 & & open & 0 & & open & 0 & on & 0 & $>0$ & open & on & $>0$ \\
\hline$\Rightarrow \begin{array}{c}\text { Water Source } \\
\text { Empty }\end{array}$ & 0 & & open & 0 & & open & 0 & on & 0 & & open & on & $>0$ \\
\hline $\begin{array}{r}\text { Water Source } \\
\text { Suct ion Blocked }\end{array}$ & 0 & & open & 0 & & open & 0 & on & 0 & $>0$ & open & on & $>0$ \\
\hline $\begin{array}{l}\text { liater Source } \\
\text { valves Closed }\end{array}$ & 0 & & open & 0 & & open & 0 & on & 0 & $>0$ & shut & on & $>0$ \\
\hline $\begin{array}{l}\text { hotive } H X \\
\text { Failed }\end{array}$ & 0 & حRV & open & $>0$ & 2RV & open & $>0$ & on & $>0$ & $>0$ & open & off & 0 \\
\hline
\end{tabular}


Figure 38. Phase 4 response tree

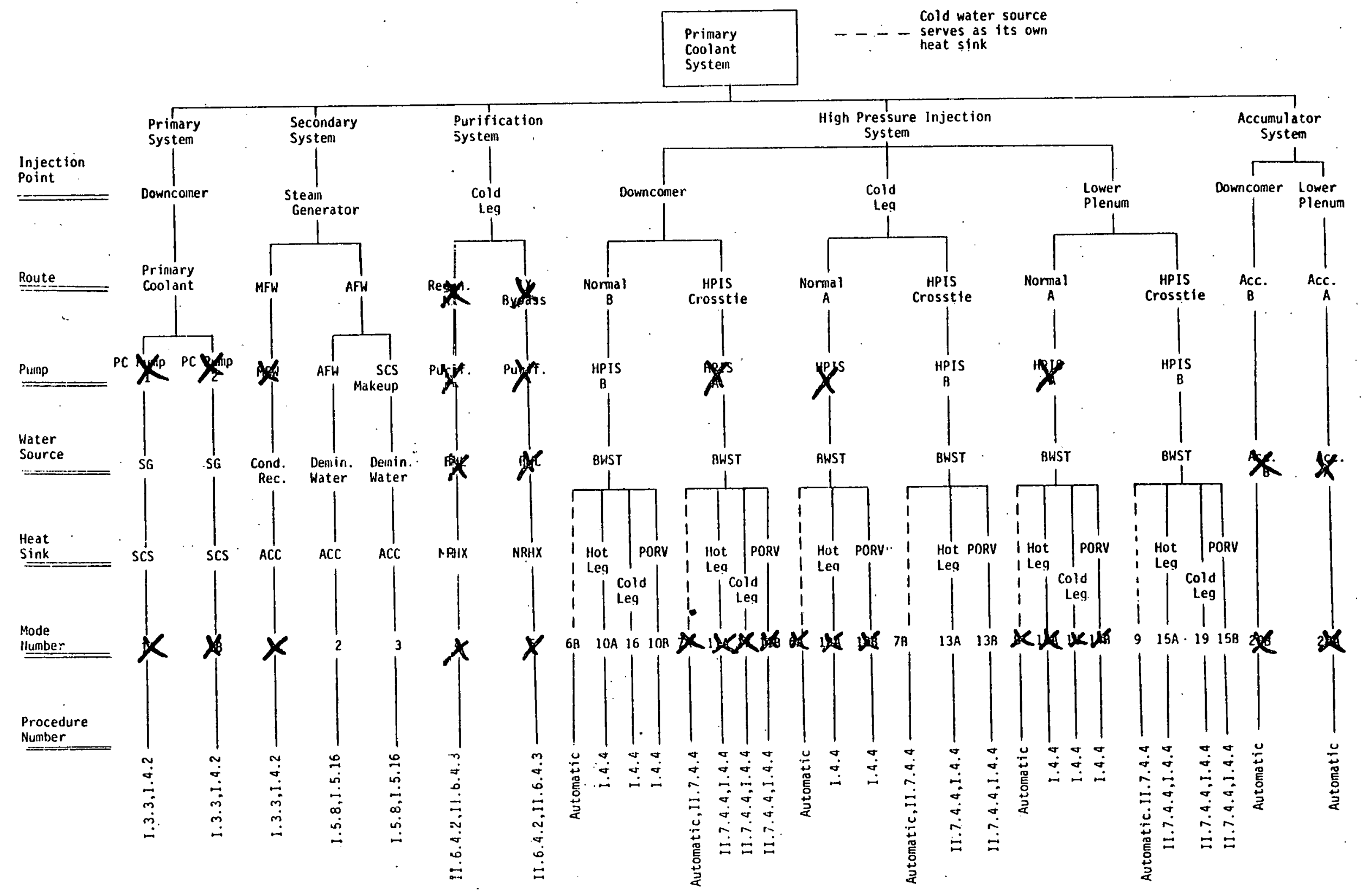


Figure 38. (cont.)

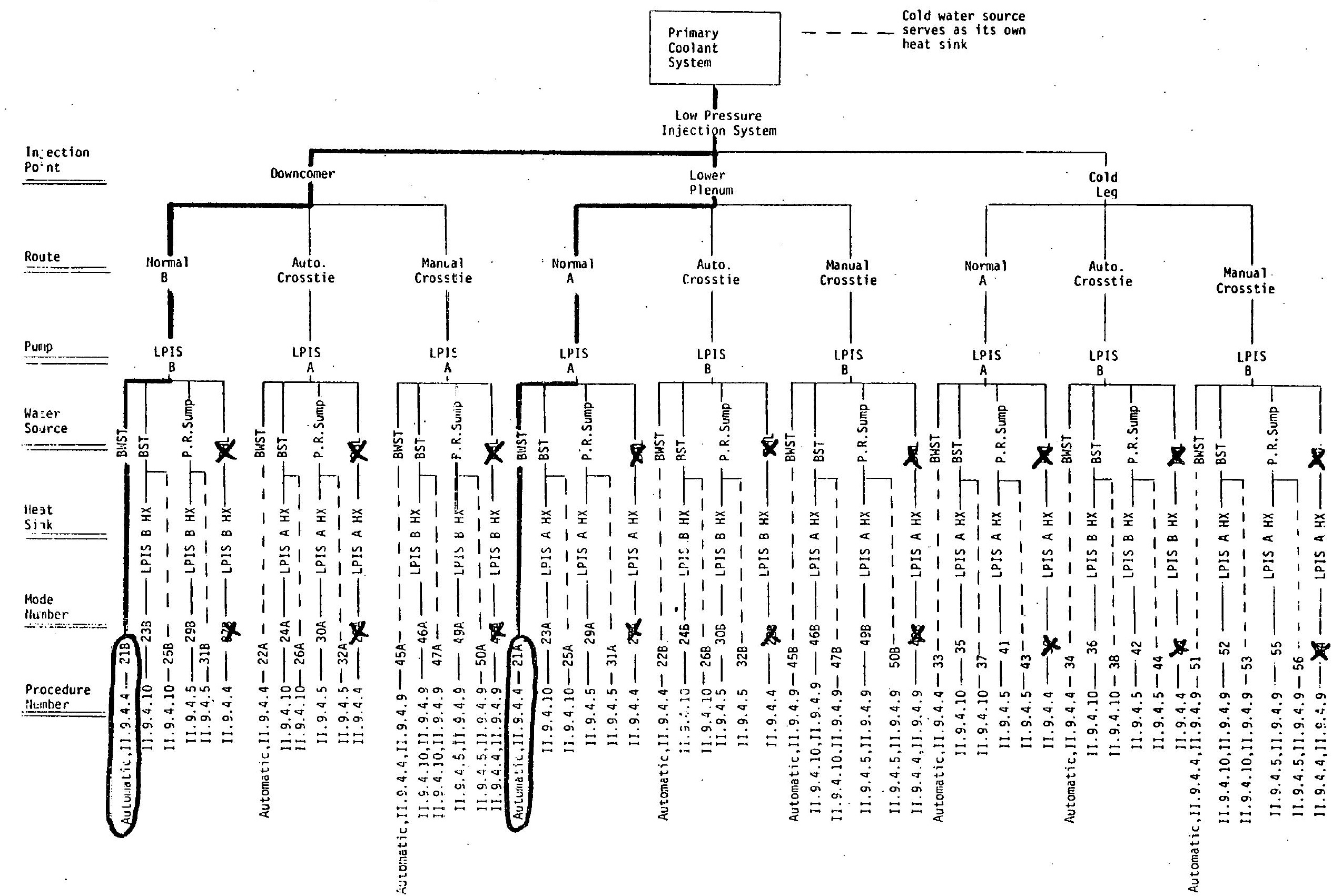


Figure 39. Phase 4 schematic

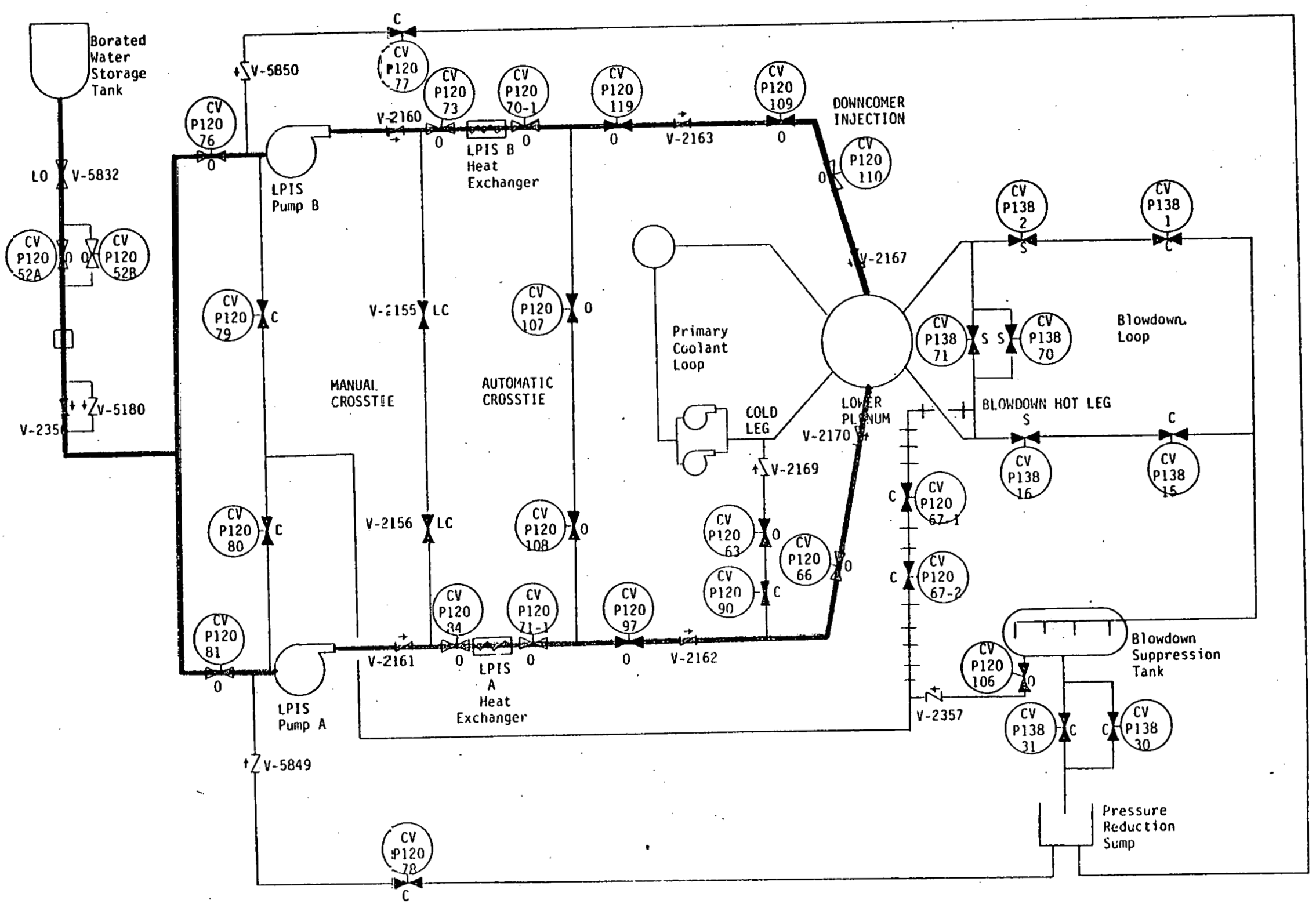


Figure 40 . Phase 5 diagnostic table

\section{BWST LOW LEVEL}

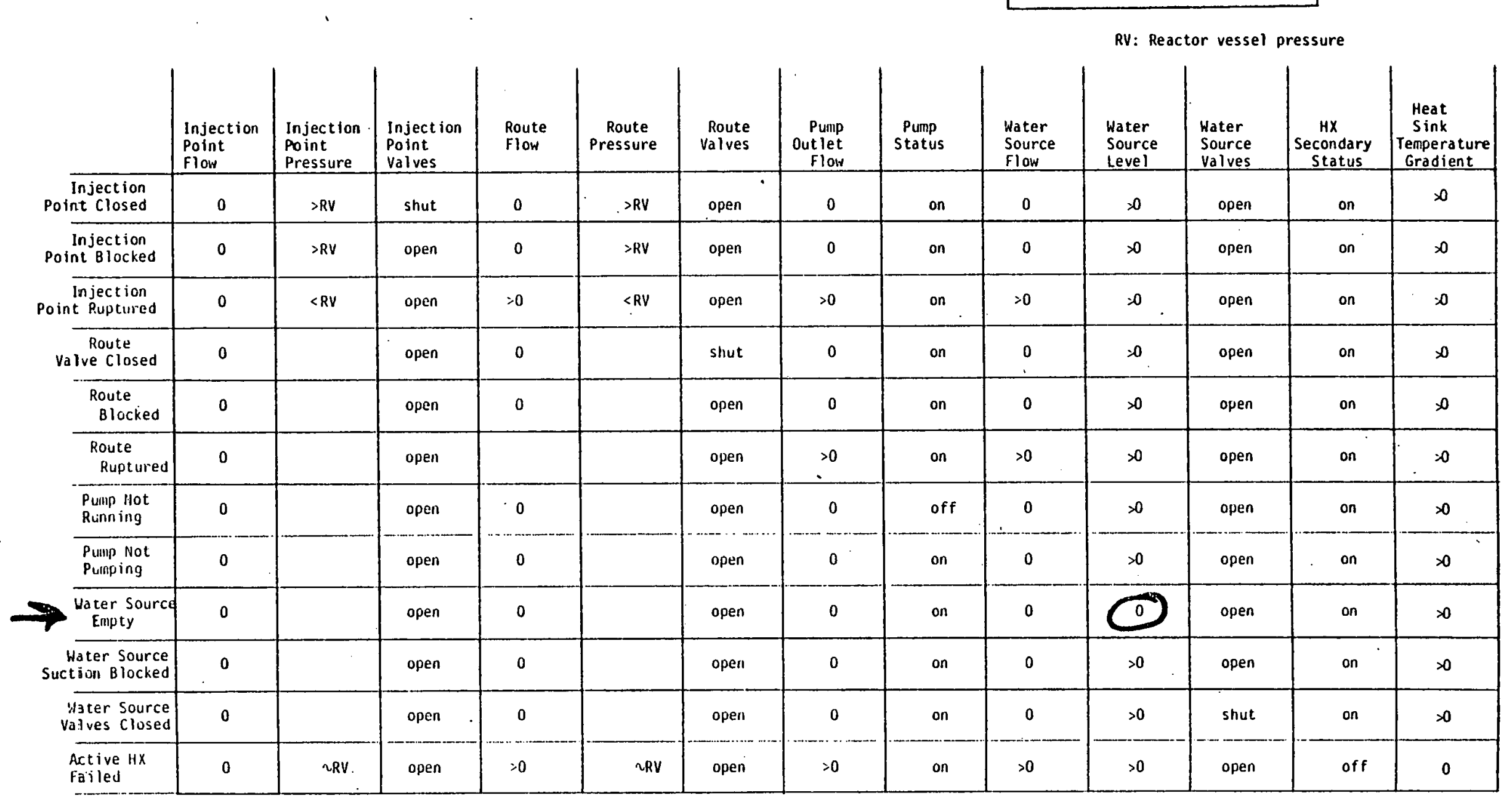


Figure 41. Phase 5 response tree

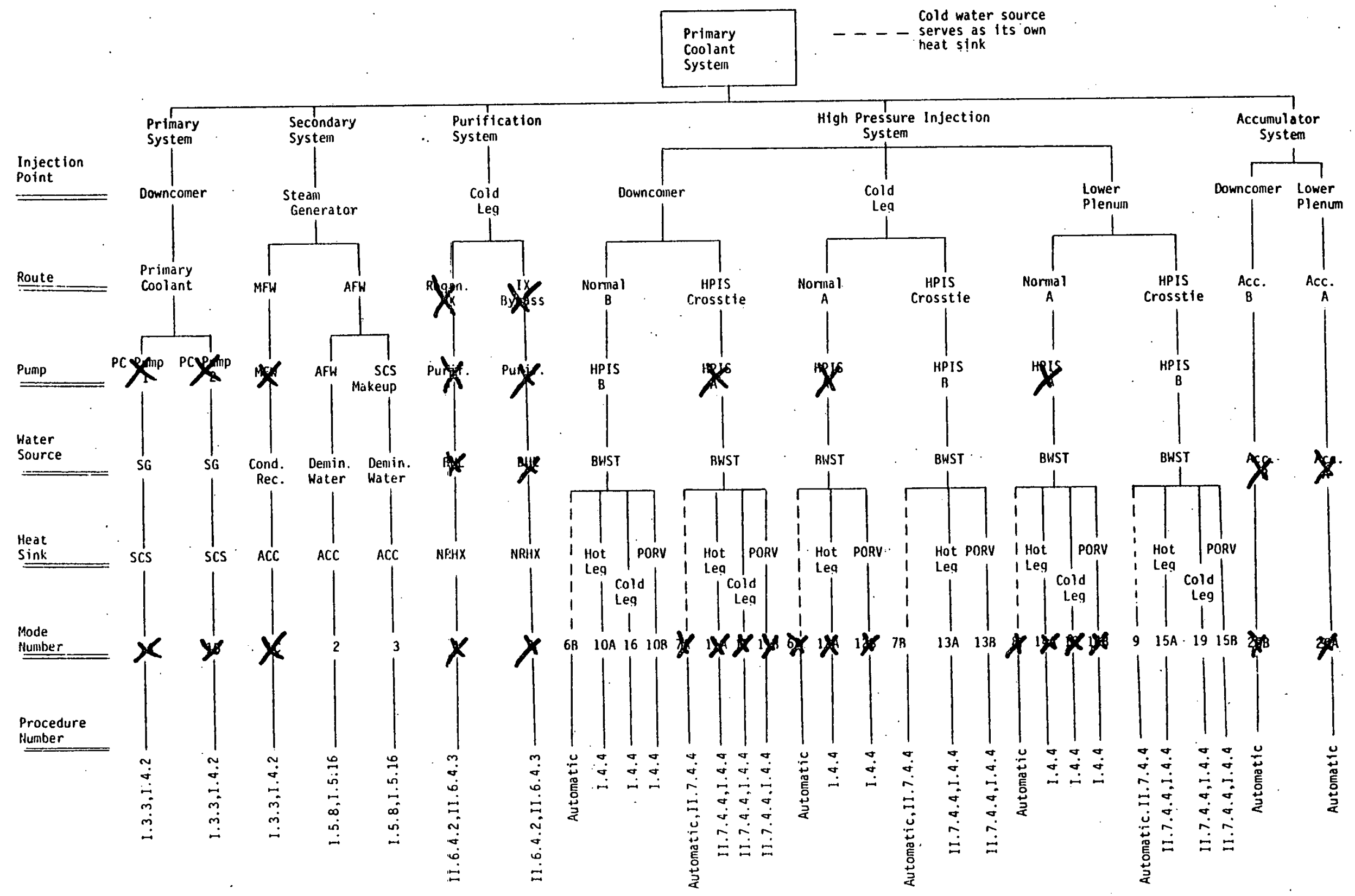


Figure 41. (cont.)

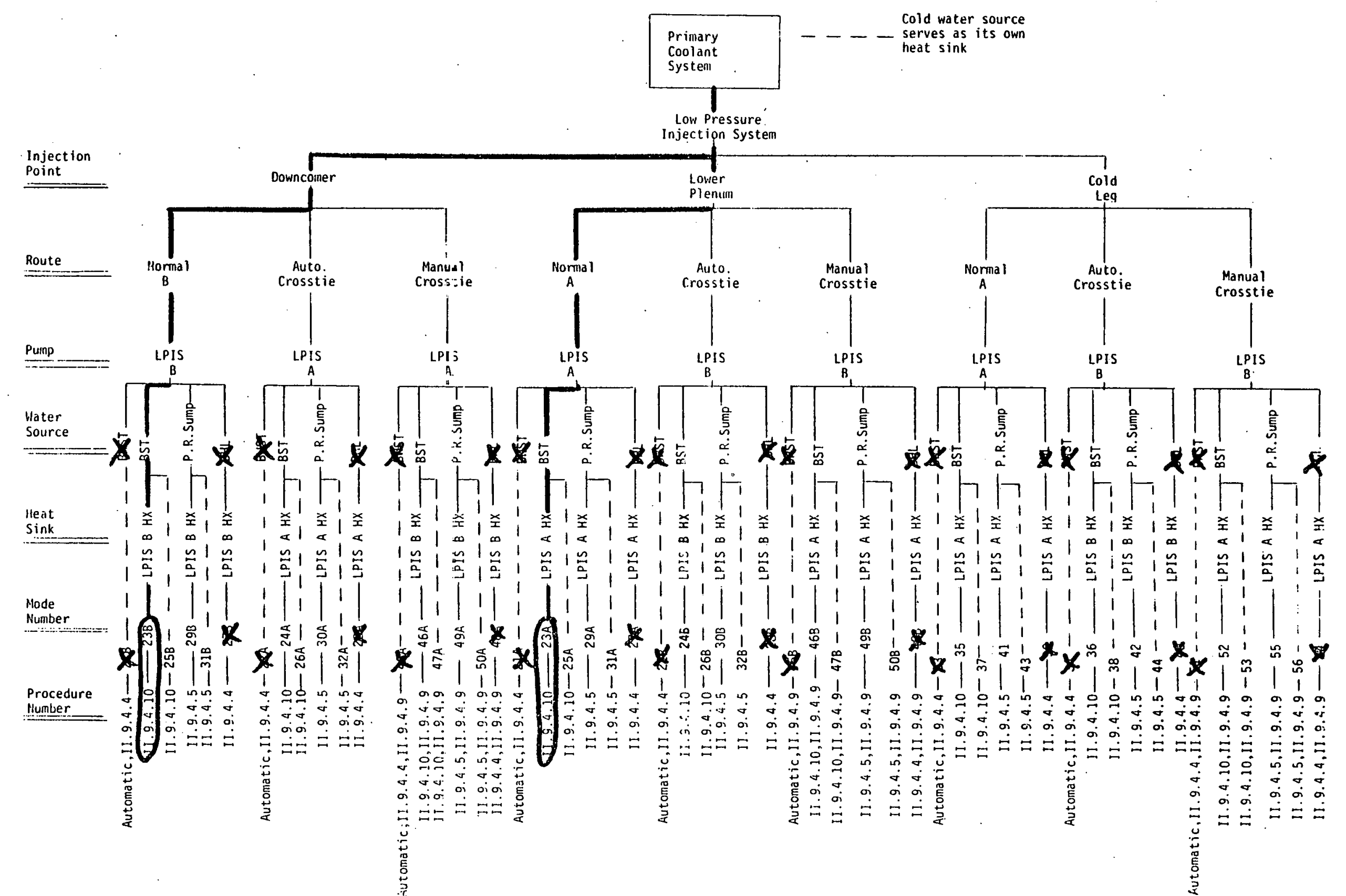


Figure 42. Phase 5 scinematic

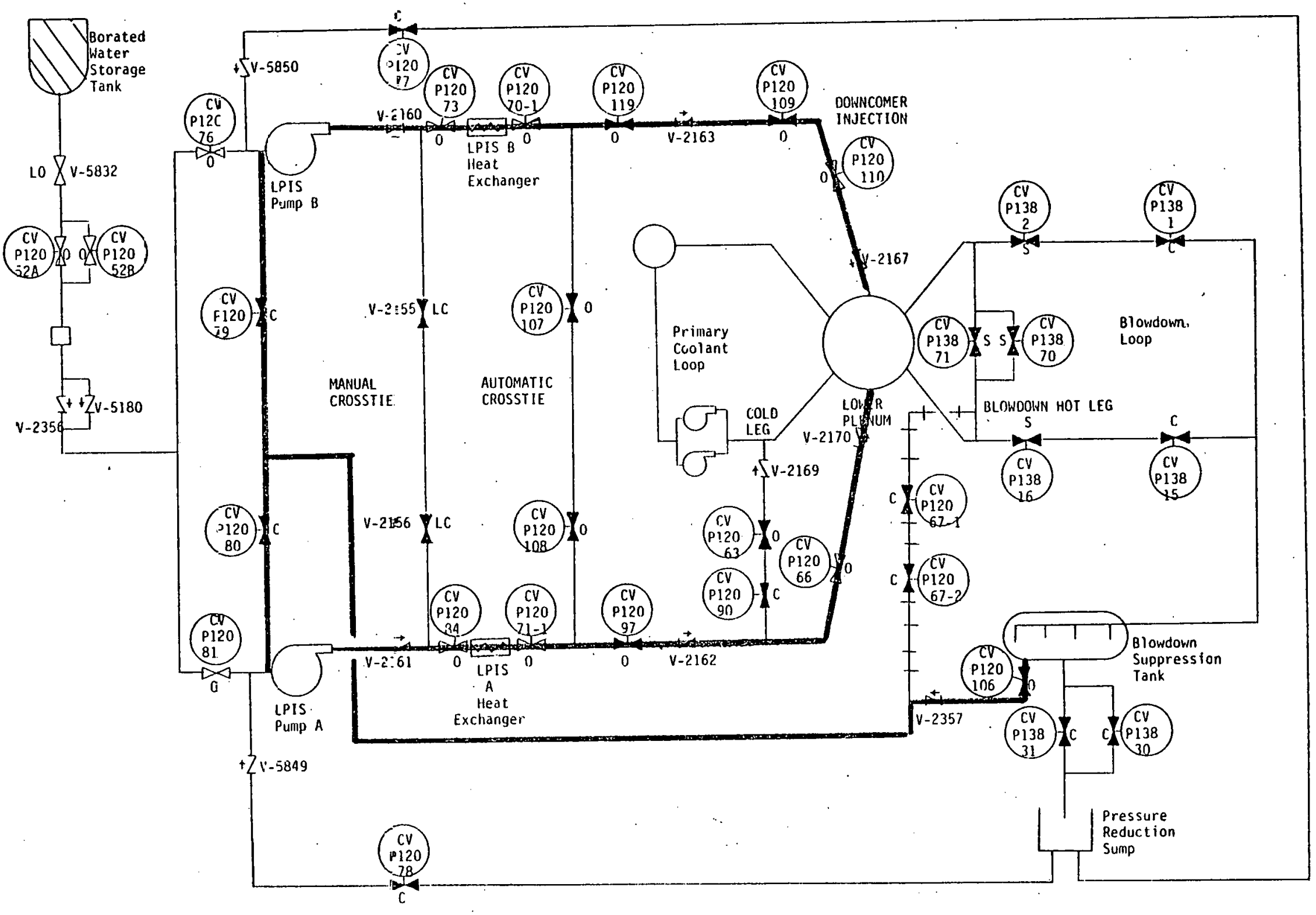


Figure 43. Phase 6 diagnostic table

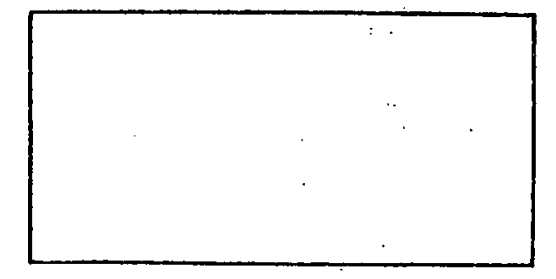

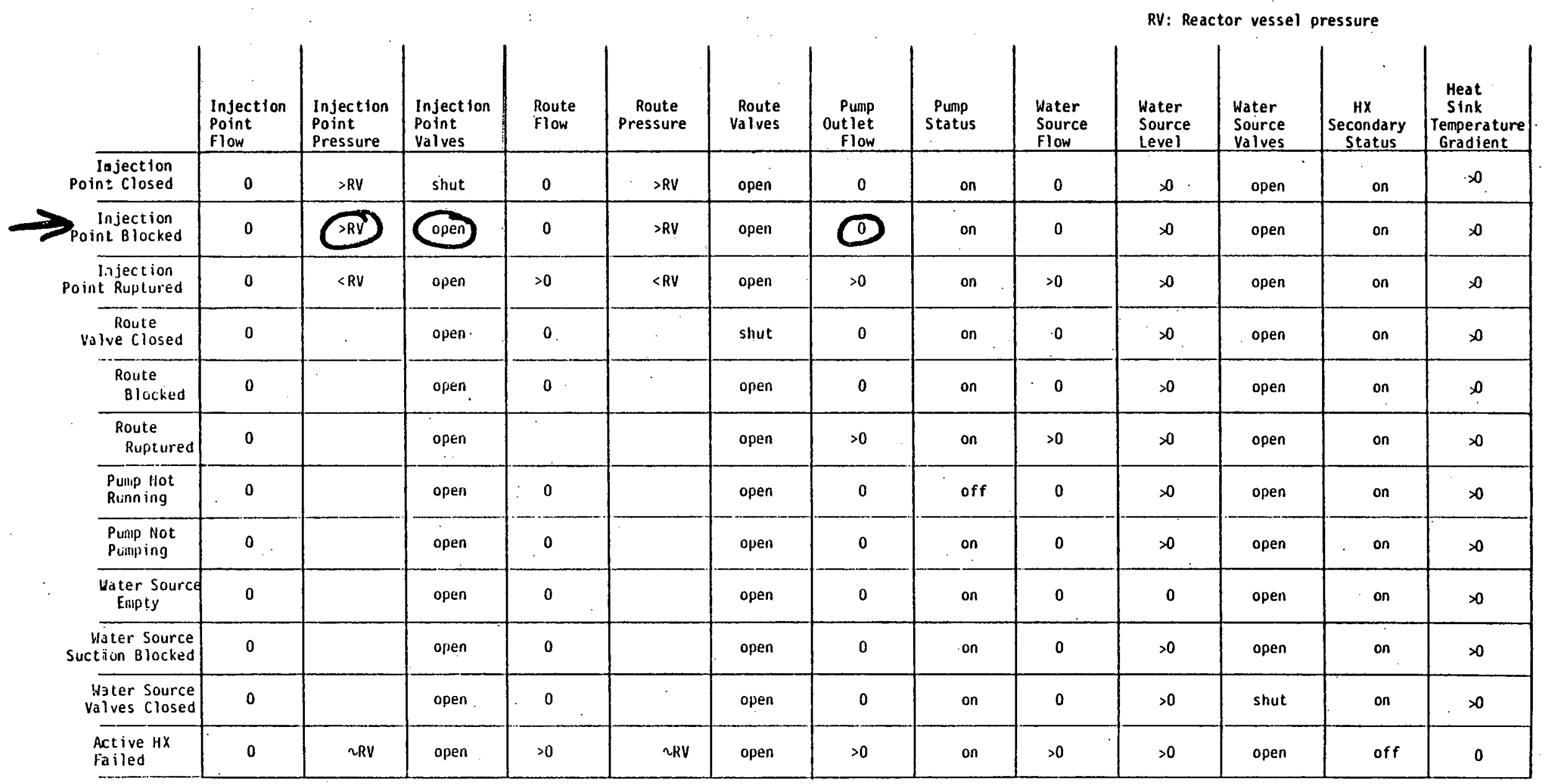


Figure 44. Phase 6 response tree

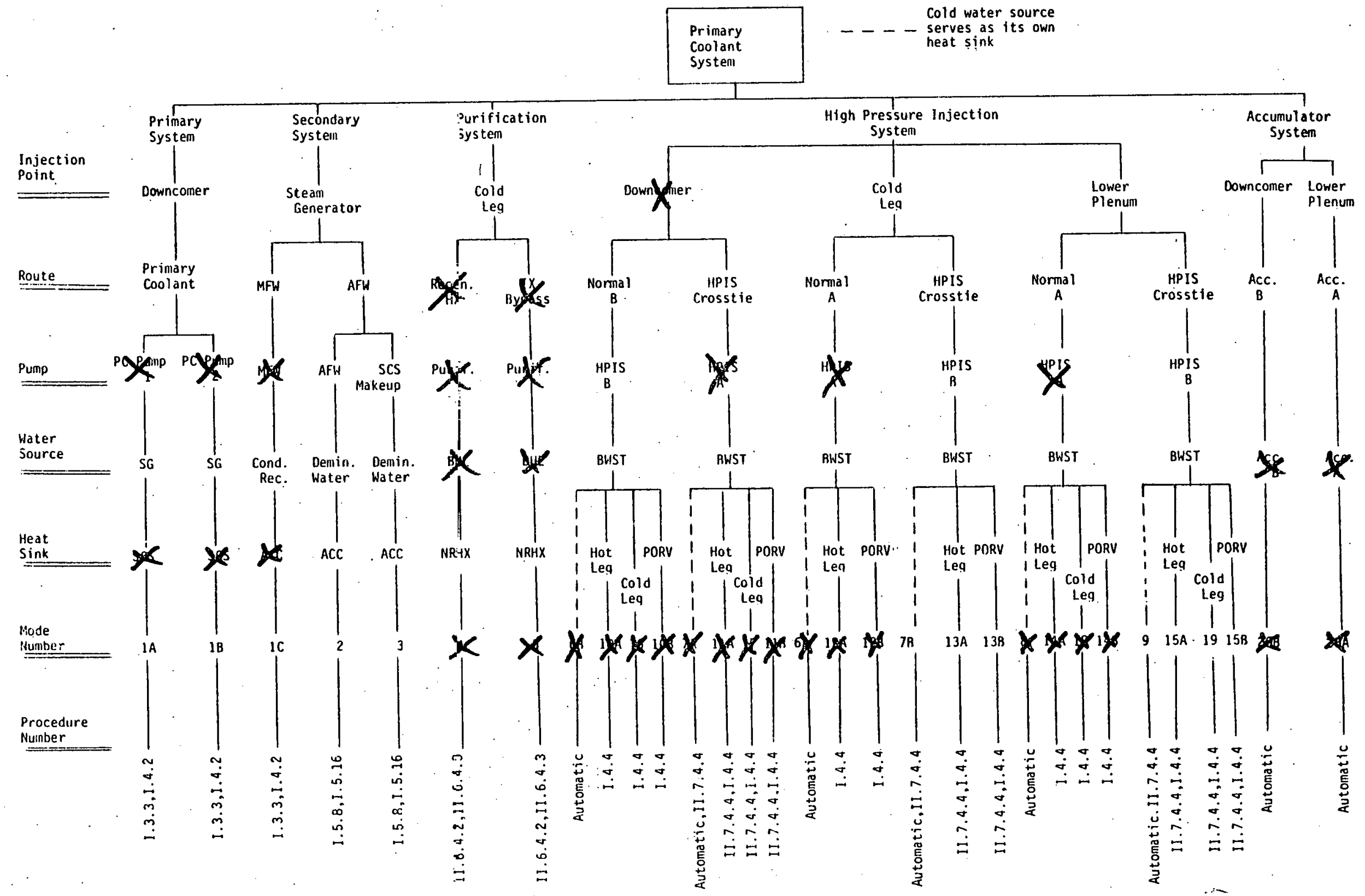


Figure 44. (cont.)

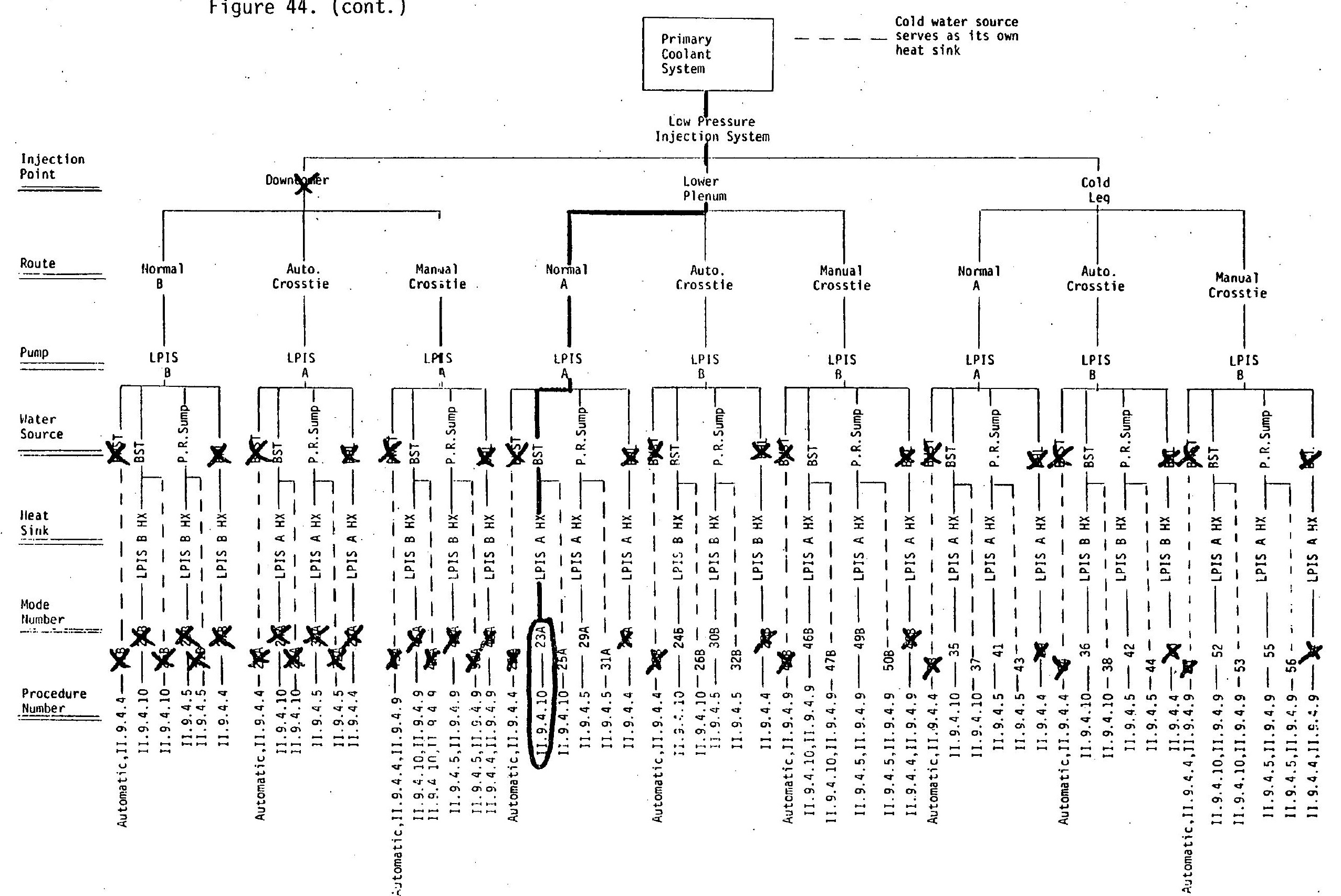


Figure 45. Phase 6 schematic

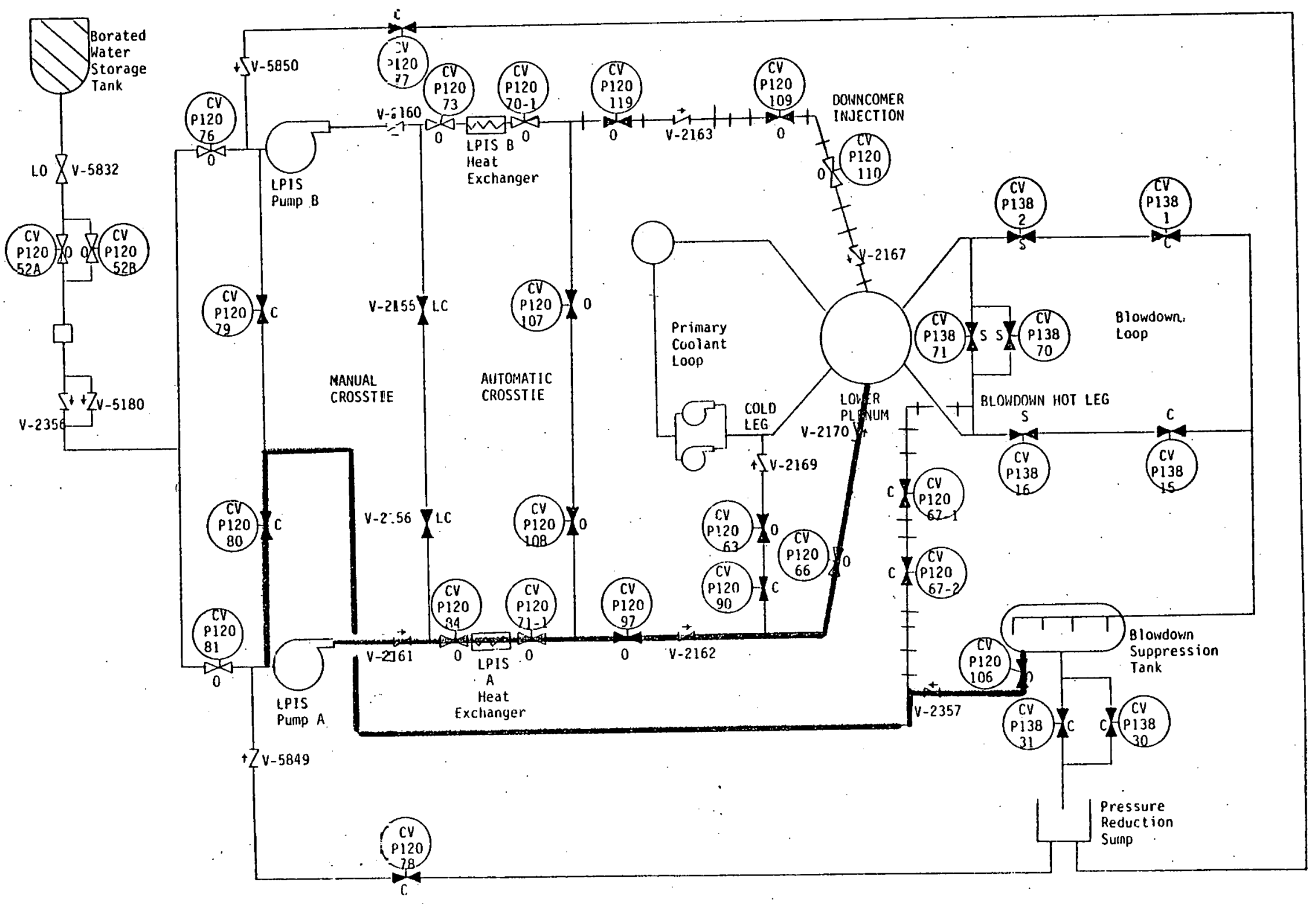


Figure 46. Phase 7 diāgnostic table

LOSS OF VITAL POWER A

RV: Reactor vessel pressure

\begin{tabular}{|c|c|c|c|c|c|c|c|c|c|c|c|c|c|}
\hline & $\begin{array}{l}\text { Injection } \\
\text { Point } \\
\text { Flow }\end{array}$ & $\begin{array}{l}\text { Injection } \\
\text { Point } \\
\text { Pressure }\end{array}$ & $\begin{array}{l}\text { Injection } \\
\text { Point } \\
\text { Valves }\end{array}$ & $\begin{array}{l}\text { Route } \\
\text { Flow }\end{array}$ & $\begin{array}{c}\text { Route } \\
\text { Pressure }\end{array}$ & $\begin{array}{r}\text { Route } \\
\text { Valves }\end{array}$ & $\begin{array}{r}\text { Pump } \\
\text { Out let } \\
\text { Flow } \\
\end{array}$ & $\begin{array}{l}\text { Pump } \\
\text { Status }\end{array}$ & $\begin{array}{l}\text { Water } \\
\text { Source } \\
\text { Flow } \\
\end{array}$ & $\begin{array}{l}\text { Water } \\
\text { Source } \\
\text { Level } \\
\end{array}$ & $\begin{array}{l}\text { Water } \\
\text { Source } \\
\text { Valves } \\
\end{array}$ & $\begin{array}{c}\mathrm{HX} \\
\text { Secondary } \\
\text { Status } \\
\end{array}$ & $\begin{array}{c}\text { Heat } \\
\text { Sink } \\
\text { Temperature } \\
\text { Gradient }\end{array}$ \\
\hline $\begin{array}{r}\text { Injection } \\
\text { Point Closed }\end{array}$ & 0 & $>R V$ & shut & 0 & $>R V$ & open & 0 & on & 0 & $\times 0$ & open & on & $\varnothing 0$ \\
\hline $\begin{array}{c}\text { Ir.jection } \\
\text { Point Blocked }\end{array}$ & 0 & $>\mathrm{RV}$ & open & 0 & $>R V$ & open & 0 & on & 0 & $>0$ & open & on & 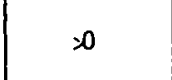 \\
\hline $\begin{array}{l}\text { Injection } \\
\text { Point Ruptured }\end{array}$ & 0 & $<R V$ & op=n & $>0$. & $<R V$ & open & $=0$ & on & $>0$ & $>0$ & open & on & $\varnothing 0$ \\
\hline $\begin{array}{c}\text { Route } \\
\text { Valye Closed }\end{array}$ & 0 & & open & 0 & & shut & 0 & on & 0 & $>0$ & open & on & $\times 0$ \\
\hline $\begin{array}{l}\text { Route } \\
\text { Blocked }\end{array}$ & 0 & & open & 0 & & open & 0 & on & 0 & 20 & open & on & $\infty 0$ \\
\hline $\begin{array}{l}\text { Route } \\
\text { Ruptured }\end{array}$ & 0 & & upen & & & open & $>0$ & on & $>0$ & $>0$ & open & on & $>0$ \\
\hline $\begin{array}{l}\text { Punp Not } \\
\text { Runn ing }\end{array}$ & 0 & & open & 0 & & open & 0 & of $f$ & 0 & $>0$ & open & on & $>0$ \\
\hline $\begin{array}{l}\text { Puinp Not } \\
\text { Plimping }\end{array}$ & 0 & & open & 0 & & open & 0 & on & 0 & $>0$ & open & on & $>0$ \\
\hline $\begin{array}{l}\text { Water Source } \\
\text { Empty }\end{array}$ & 0 & . & open & 0 & & open & 0 & on & 0 & 0 & open & on & $\infty$ \\
\hline $\begin{array}{r}\text { Ha ter Source } \\
\text { Suct ion Blocked }\end{array}$ & 0 & & open & 0 & & open & 0 & on & 0 & $>0$ & open & on & $\varnothing 0$ \\
\hline $\begin{array}{r}\text { Water Source } \\
\text { vaives Closed }\end{array}$ & 0 & & open & 0 & . & open & 0 & on & 0 & $>0$ & shut & on & $>0$ \\
\hline $\begin{array}{l}\text { Active } H X \\
\text { Failed }\end{array}$ & 0 & URV & open & $>0$ & ZRV & open &.$>0$ & on & $>0$ & $>0$ & open & off & 0 \\
\hline
\end{tabular}


Figure 47 . Phase 7 response tree

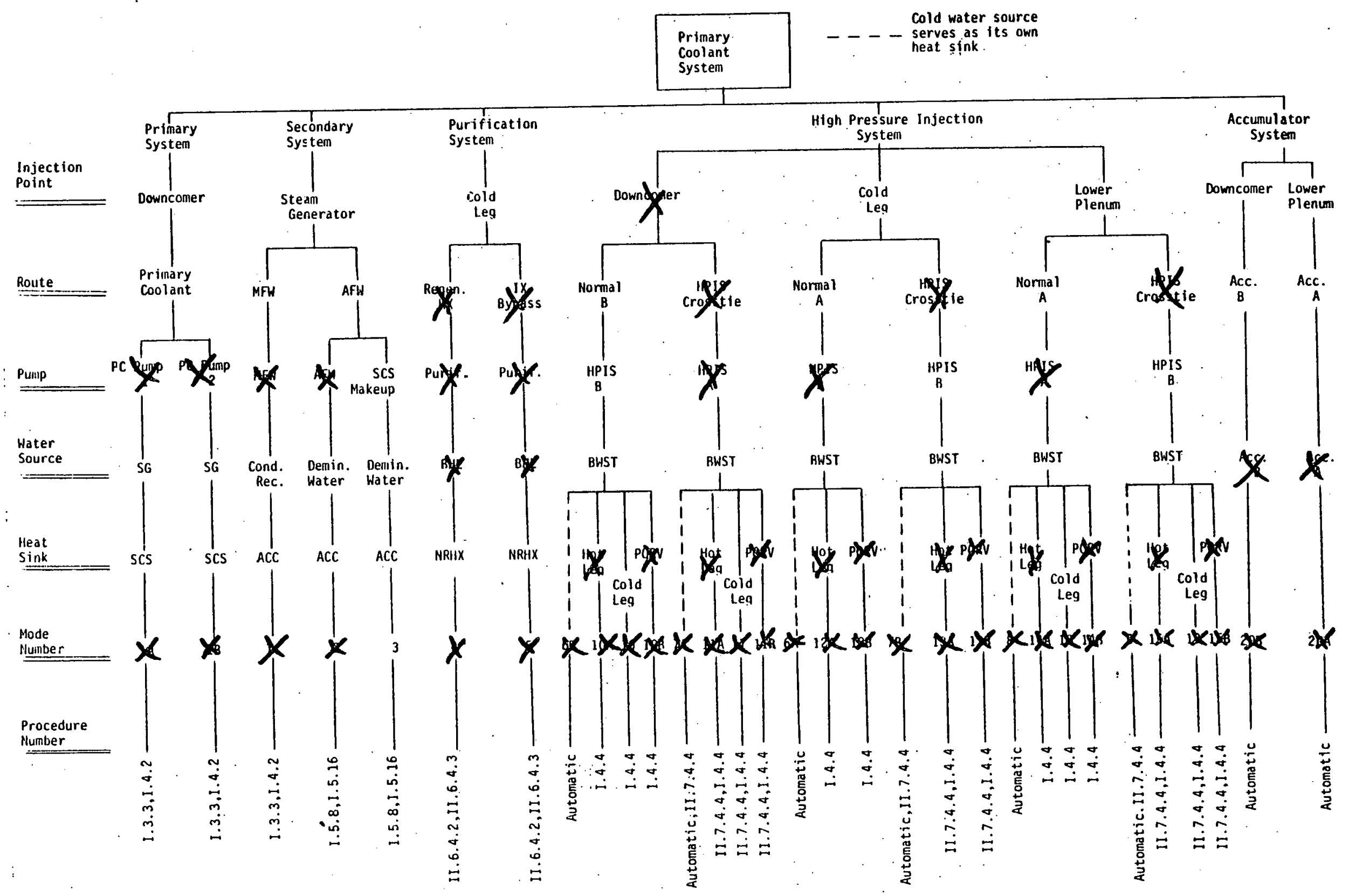


Figure 47 . (cont.)

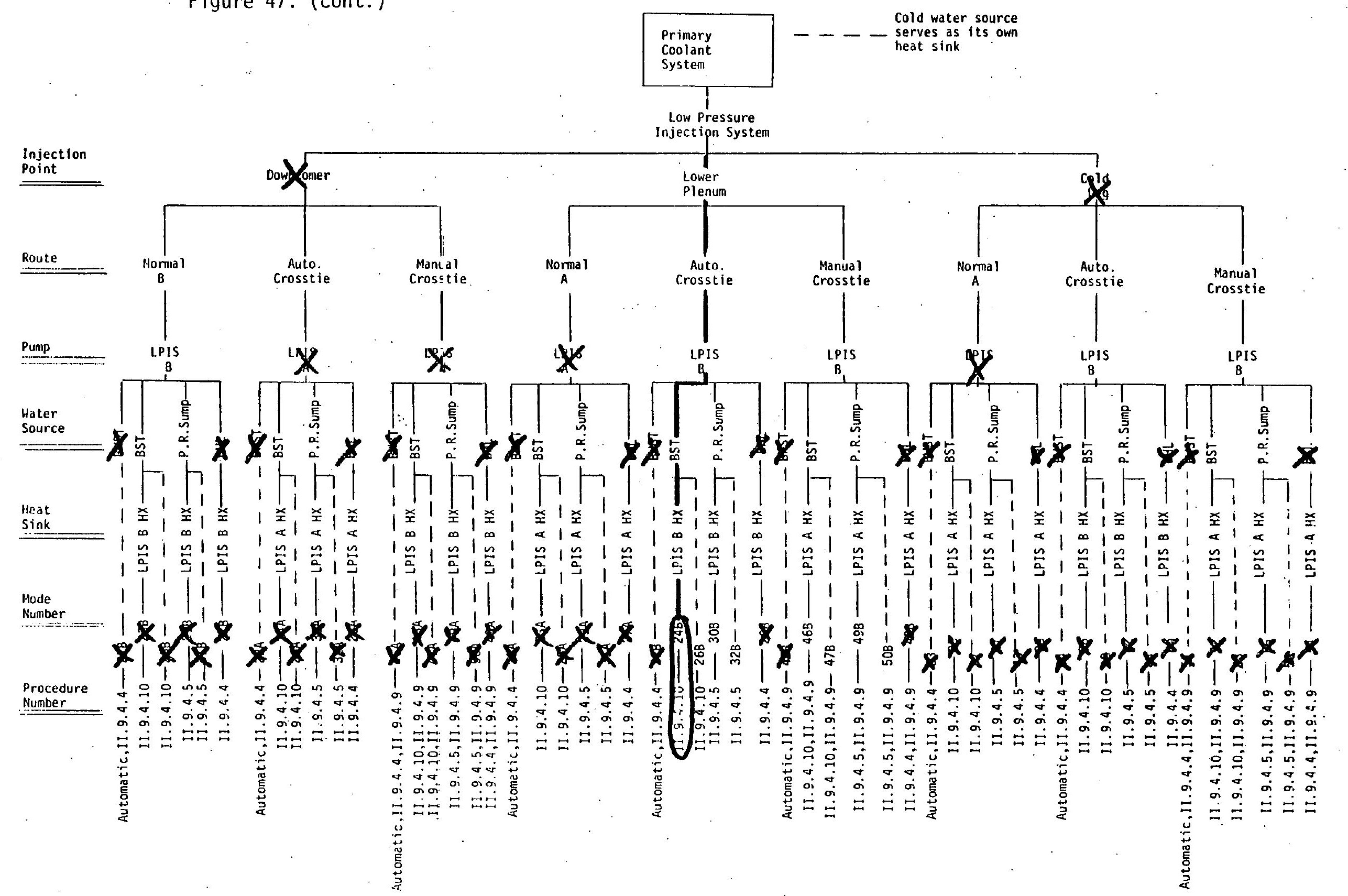


Ficure 48. Phase 7 scrematic

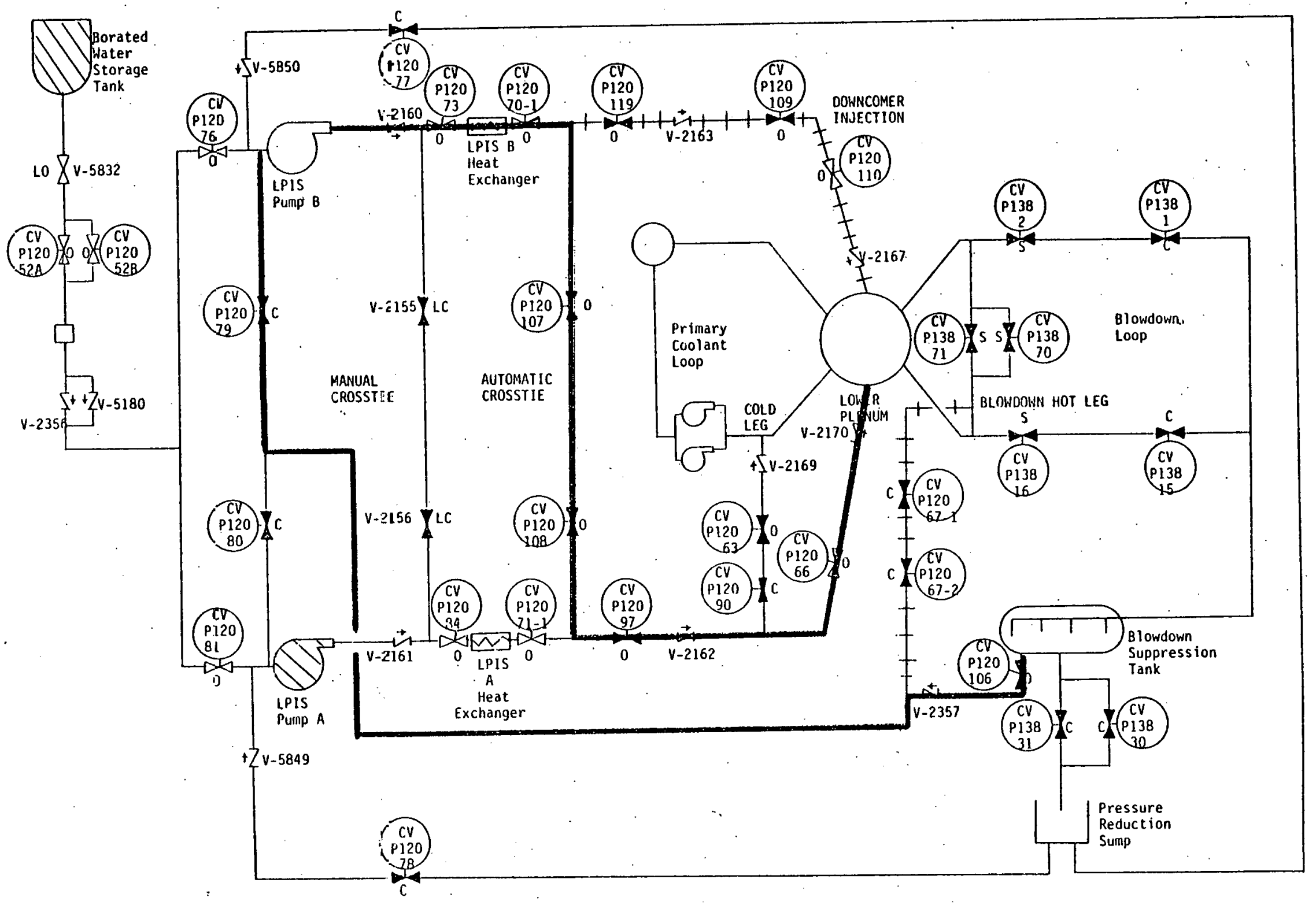




\subsubsection{Phase. Eight.}

LPIS Pump B outlet flow goes to zero. A valve indicator in the automatic crosstie indicates that the valve is shut. Displays are updated as shown in Figure 49, 50 and 51 . Mode $46 \mathrm{~B}$ is recommended. The operator opens the manual crosstie line as instructed by Procedure II. 9.4.9, so that flow from LPIS Pump $B$ can be directed through the manual crosstie to the lower plenum injection point.

This process of system monitoring and cooling mode implementation is continued until the cold shutdown condition is reached. As more failures occur or components are repaired, the response trees are continually evaluated and the displays are updated to keep the operator informed about current conditions. 
Figure 49. Phase 8 diagnostic table

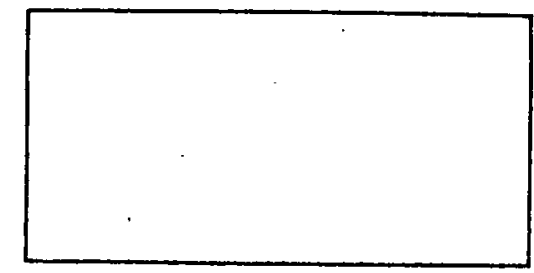

RV: Reactor vessel pressure

\begin{tabular}{|c|c|c|c|c|c|c|c|c|c|c|c|c|c|}
\hline & $\begin{array}{l}\text { Injection } \\
\text { Point } \\
\text { Flow }\end{array}$ & $\begin{array}{l}\text { Injection } \\
\text { Point } \\
\text { Pressure } \\
\end{array}$ & $\begin{array}{l}\text { Inject ion } \\
\text { Point } \\
\text { Valves } \\
\end{array}$ & $\begin{array}{l}\text { Route } \\
\text { Flow }\end{array}$ & $\begin{array}{c}\text { Route } \\
\text { Pressure }\end{array}$ & $\begin{array}{r}\text { Route } \\
\text { valves }\end{array}$ & $\begin{array}{r}\text { Pump } \\
\text { Out let } \\
\text { Flow } \\
\end{array}$ & $\begin{array}{l}\text { Pump. } \\
\text { Status }\end{array}$ & $\begin{array}{l}\text { Water } \\
\text { Source } \\
\text { Flow } \\
\end{array}$ & $\begin{array}{l}\text { Water } \\
\text { Source } \\
\text { Leve? }\end{array}$ & $\begin{array}{l}\text { Water } \\
\text { Source } \\
\text { Valves } \\
\end{array}$ & $\begin{array}{c}H X \\
\text { Secondary } \\
\text { Status }\end{array}$ & $\begin{array}{c}\text { Heat } \\
\text { Sink } \\
\text { Tempera ture } \\
\text { Gradient }\end{array}$ \\
\hline $\begin{array}{r}\text { Iojection } \\
\text { Point Closed }\end{array}$ & 0 & $>R V$ & shut & 0 & $>R V$ & open & 0 & on & 0 & $>0$ & open & on & $\$ 0$ \\
\hline $\begin{array}{c}\text { Injection } \\
\text { Point Blocked }\end{array}$ & 0 & $>R V$ & open & 0 & $>R V$ & open & 0 & on & 0 & $>0$ & open & on & $>0$ \\
\hline $\begin{array}{c}\text { Injection } \\
\text { Point Ruptured }\end{array}$ & 0 & $<R V$ & open & $>0$ & $<R V$ & open & $>0$ & on & $>0$ & $>0$ & open & on. & $>0$ \\
\hline $\begin{array}{c}\text { Poute } \\
\text { Value Closed }\end{array}$ & 0 & & open & 0 & & & 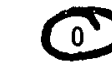 & on & 0 & $>0$ & open & on & $\therefore 0$ \\
\hline $\begin{array}{l}\text { Route } \\
\text { Blocked }\end{array}$ & 0 & & open & 0 & & open & 0 & on & 0 & $>0$ & open & on & $=0$ \\
\hline $\begin{array}{l}\text { Route } \\
\text { Ruptured }\end{array}$ & 0 & & open & & & open & $>0$ & on & $>0$ & $>0$ & open & on & $\infty$ \\
\hline $\begin{array}{l}\text { Pump llot } \\
\text { Running }\end{array}$ & 0 & & open & 0 & $\cdot$ & open & 0 & off & 0 & $>0$ & open & on & $=0$ \\
\hline $\begin{array}{l}\text { Pump Not } \\
\text { Puinping }\end{array}$ & 0 & & open & 0 & & open & 0 & on & 0 & $>0$ & open & on & $>0$ \\
\hline $\begin{array}{l}\text { Hater Source } \\
\text { Enipty }\end{array}$ & 0 & & open & 0 & & open & 0 & on & 0 & 0 & open & on & $\infty$ \\
\hline $\begin{array}{r}\text { Water Source } \\
\text { Suction Blocked }\end{array}$ & 0 & & open & 0 & & open & 0 & on & 0 & $>0$ & open & on & $>0$ \\
\hline $\begin{array}{r}\text { Wáter Source } \\
\text { Valves Closed }\end{array}$ & 0 & & open & 0 & & open & 0 & on & 0 & $>0$ & shut & on & $>0$ \\
\hline $\begin{array}{l}\text { Active } H X \\
\text { Failed }\end{array}$ & 0 & uRV & open & $>0$ & 2RV & open & $>0$ & on & $>0$ & $>0$ & open & off & $D$ \\
\hline
\end{tabular}


Figure 50. Phase 8 response tree

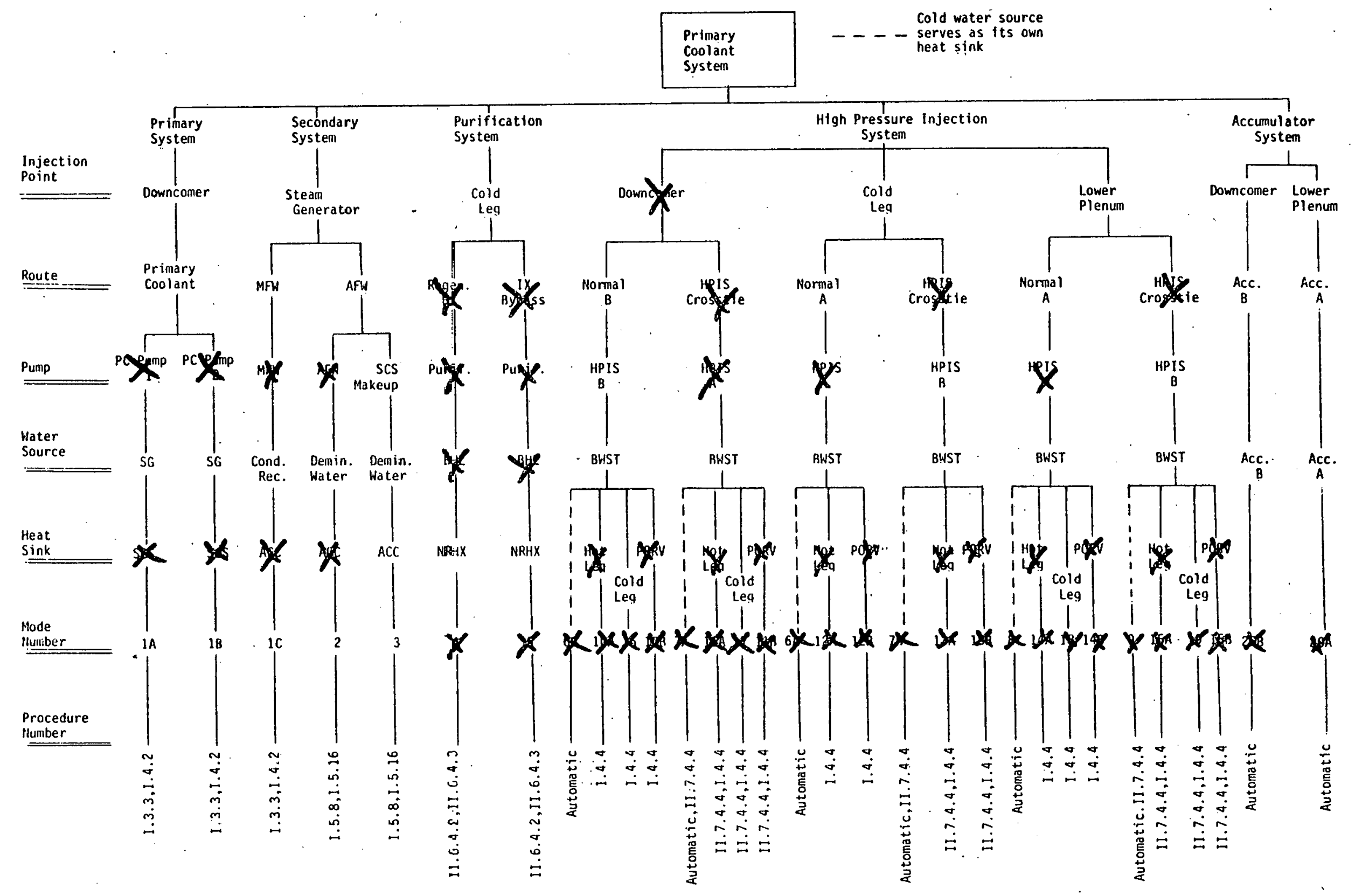


Figure 50. (cont.)

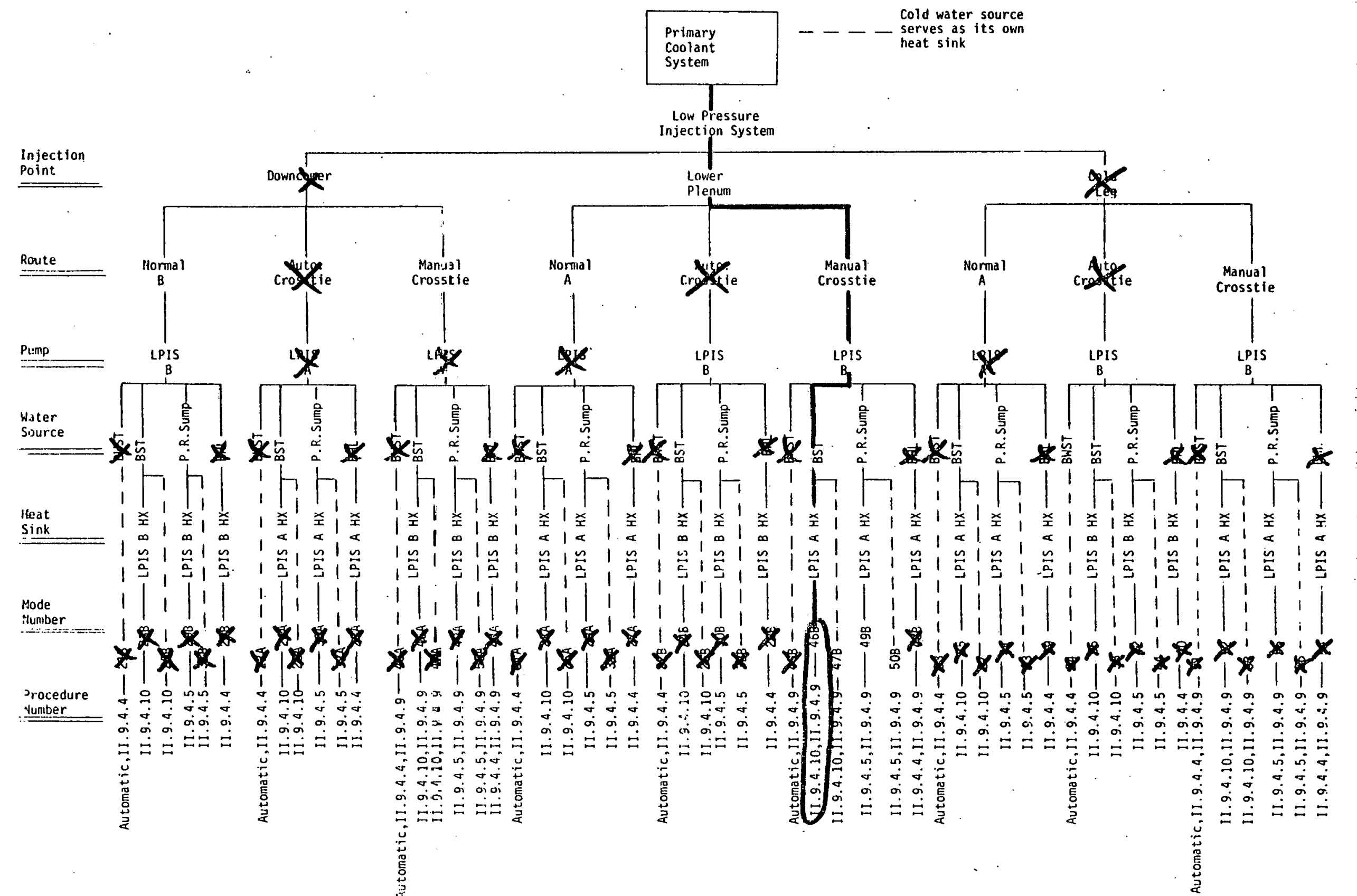


Figure 51. Phase 8 scrematic

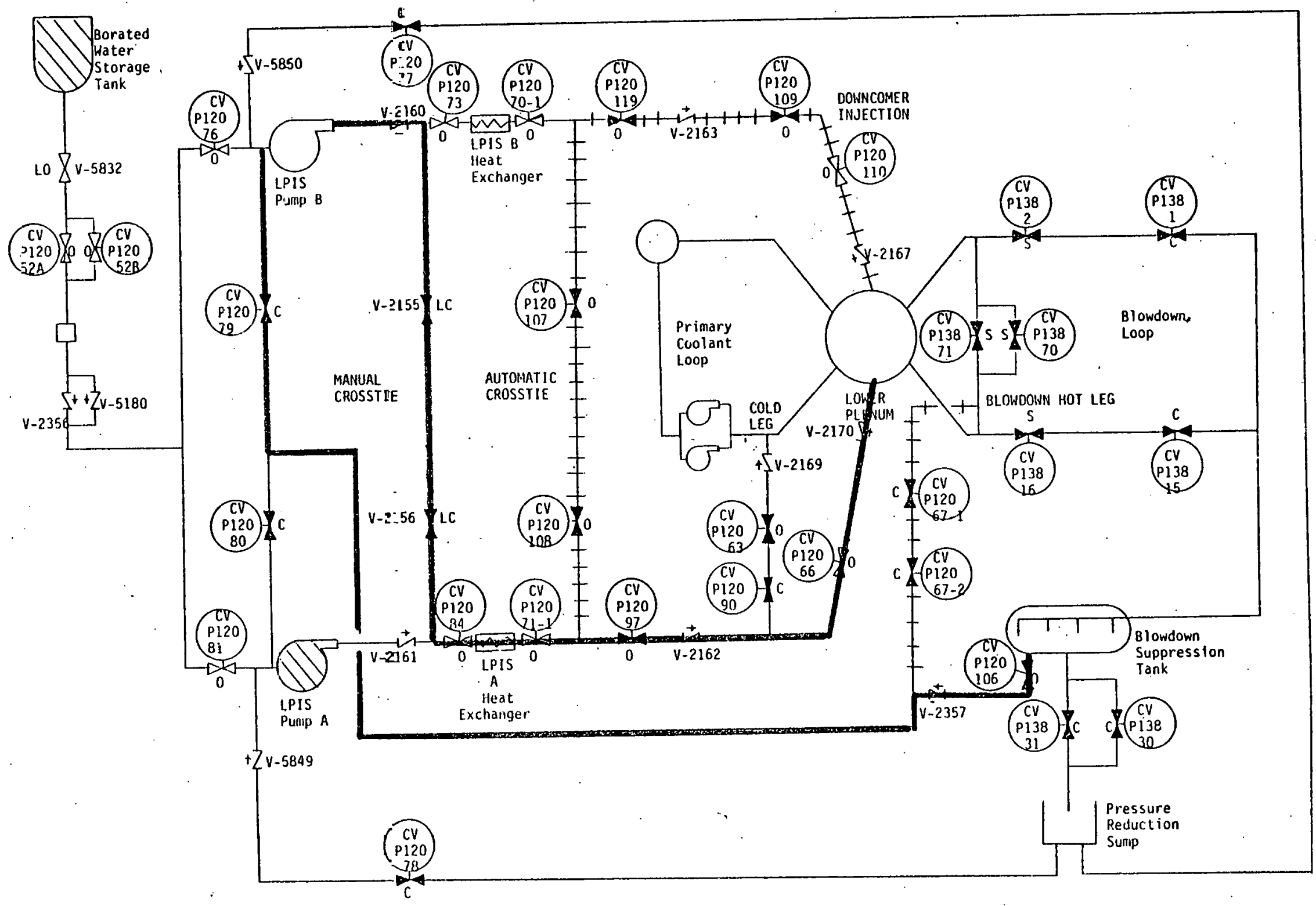




\section{CONCLUSIONS}

In Section 1.4 of this report functional requirements for an operator information system were proposed. The response tree methodology is a first step toward a comprehensive system which can satisfy these requirements. The expanded response tree methodology represents a significant advancement over currently available diagnostic systems, as such systems are currently very primitive or nonexistent. The parameters monitored by the response trees are characteristic parameters which can be evaluated to provide guidance when system malfunctions occur. If the response chosen for a particular accident is not adequate, response trees can be used to select an alternative action. All this information can be presented to the operator using color graphic displays.

Response trees could be implemented without excessive modifications to existing control rooms. All that is necessary is to program a computer with the response tree logic and use it to drive color graphic displays. It would be necessary to construct and configure the computer to provide sufficient reliability to qualify as a safety related system. Only extensive application of the response tree methodology will demonstrate whether it can provide the operator with meaningful, believable, and correct information.

The use of response trees for detecting, diagnosing, and treating reactor accidents could provide a significant reduction. in the risks associated with nuclear reactor accidents. Some of the benefits inherent in the response tree methodology are:

- Response trees emphasize immediate response to emergency situations. Fault diagnosis can be delayed until time permits.

0 They treat an accident after it occurs. A predetermined list of potential accident sequences is not required. 
- The logic models are relatively simple. The response tree shows the basic relationships between plant systems and components.

- The effects of support system failures can easily be modeled and visualized.

- Response trees treat all accidents equaliy no matter what their probability of occurrence. The "it can't happen" syndrome is avoided.

- Response trees can handle common cause and multiple failures.

- Response trees are relatively easy to develop.

An important feature of response trees is that they provide a concise "picture" of the operation of a complex system. The trees can easily be used to visualize the effects of complex accident sequences on the operation of the plant. For this reason, response trees could be used for purposes other than accident diagnosis. They could be used to evaluate different design options when the preliminary design of a facility is in progress. They could be used to evaluate various accident sequences for safety analyses of a facility. Finally, the trees could be used in a training program to help operations, maintenance, technical, and management personnel gain an appreciation for the operation of the facility.

The potential uses of the response tree methodology still remain largely unexplored. Much additional work is needed to develop the methodology. The effects of system interactions need to be explored in more detail. Diagnosis of component malfunctions needs to be investigated so that inadequate instrumentation, failed instruments, and extraneous symptoms $c$ an be accommodated. A more rigorous way to determine the availability of a component before it is needed would be helpful. A comprehensive language or "protocol" for communication between the operator and the computer must be developed. More advanced display concepts should be evaluated. 
Two potentially exciting concepts remain to be explored. The first is to use a computer to automatically generate response trees from system schematics. The second is to use response trees as "automatic procedure generators." During an accident sequence, for example, the computer could actually use the response trees to tell the operator which valves to open and which pumps to start. Rather than requiring the operator to refer to a procedures manual to perform an action, the computer could generate the procedure based on the accident in progress - a true "event generated procedure."

Much work remains to fully explore the potential of the response tree technique. The LOFT Augmented Operator Capability Program will provide the framework on which further studies are conducted. 


\section{REFERENCES}

1. David Meister and Gerald F. Rabideau, Human. Factors Evaluation in System Development, New York: John Wiley and Sons, Inc., 1965.

2. Lawrence J. Fogel, Biotechnology:-CEncepts and Applications, Englewood Cliffs, $\mathrm{NJ}$ : Prentice-HaTT, Inc., 1963.

3. Robert M. Gagne ed, Psychological Principles in System Development, New York: Holt, Rinehart, and Winston, Inc., 1962.

4. U.S. Department of Defense, Human Engineering Requirements for Military Systems; Equipment; and-Facilities, MIL-H-46855A, JuTy 25, 1978.

5. U.S. Department of Defense, Human Engineering Design Criteria for Military-Systems; Equipment; and-Facilities, MIL-STD-1472B, December 31, T974.

6. j. L. Seminara et al., Human Factors Review of Nuclear. Power Plant Eentro1-Room-Design, EPRI-NP-309, November 1976.

7. Ze inab A. Sabri et ai., An-Operator Model for Reliability and Availability-Evaluation-of-Nuelear-Power-Plants, ISU-ERI-AMES-76328, May 1976.

8. U.S. Atomic Energy Commission, Reactor. Safety-Study: An-Assessment-of Ace ideat-Risks - in -U:S:-Commereia\}-Auclear-Power-PlaAts, WASH-1400, August TY74.

9. U.S. Nuclear Regulatory Commission, Manual Initiation-of Protective Actions, Regulatory Guide 1.62, October 1973.

10. U.S. Nuclear Regulatory Commission, Instrumentation for Eight-Water-Eooled-Nuclear. Power Plants-to-Assess-Plant Conditions - During and-Following An Accident, Regulatory Guide T.97, December 1975.

11. U.S. Nuclear Regulatory Commission, Guidance-on. Being-Operator-at the Eontrols of a Nuclear. Power.Plant, Regulatory Guide 1.114, November 1976.

12. R. S. Denning, N. E. Miller, and A: M. Plummer, Monitoring.Postaceident Eonditions-in-Power-Reactors, BMI-X-647, April 9, 1973.

13. R. C. Gonzalez and L. C. Howington, "Machine Recognition of Abnormal Behavior in Nuclear Reactors," IEEE-Transactions on Systems, Man, and Eyberneties; SME-7, No. 10, October 1977. 
14. U.S. Nuclear Regulatory Commission, Plan for Research to Improve the Safety-of-Light-Water-Nuelear-Power-Plants, NUREG-0438, Apri1 1978.

15. U.S. Nuclear Regulatory Comission, Investigation into the March 28, 1979 Three Mile-Island-Accident-by the Office-of -Inspection-and-Enforcement, NUREG-0600; August 1979.

16. John G. Kemeny et a1., The Need-For-Ehange: - The Legacy-of. TMI, Report of the President's Commission on the Accident at Three Mile Island, October 1979.

17. U.S. Nuclear Regulatory Commission, Staff-Report on the Generic Assessment - of - Feedwater-Transients in-Pressurized-Water-Reactors - Designed by-the-Babcock and-Wilcox-Company; NUREG-0560, May 1979.

18. U.S. Nuclear Regulatory Commission, TMI-2-Lessons Learned-Task-Force Final-Report, NUREG-0585, October 1979.

19. T. B. Malone et al., Human-Factors Evaluation-of-Controt-Room Design-and Operator Performance at Three-Mile-Is land-2, NUREG/CR-1270, January 1980.

20. Mitchell Rogovin et a1., Three-Mile-Island:-A-Report-to-the Eomissioners and to the Public, Nuclear Regulatory Commission Special Inquiry Group.

21. Lockheed Missiles \& Space Co. Inc., Human Factors Methods tor Nuclear Eontrol-Room-Design, EPRI NP-1118-SY, June 1979.

22. Thomas B. Sheridan, "Human Error In Nuclear Power Plants;" Fechnology Review, February 1980. 
23. H. P. 01 son et a1., Automatic Diagnosis of Alarms: - A System to Improve Operator Emergency. Response, DP-MS-80-28X, Savannah River Laboratory, 1980.

24. Howard E. Lambert and George Yadigaroglu, "Fault Trees for Diagnosis of System Fault Conditions," Auclear-Seience-and-Engineering, 62, 1977.

25. W. E. Buttner et a1., "Data Base Preparation and Operational Features of the Disturbance Analysis System for the Grafenrheinfeld Nuclear Power Plant," Symposium on Water Reactor-Fuel-Performance and Application- of Process - Computers-in-Reactor-Operations;-Loen;- Horway, June 4-9, 1978.

26. W. R. Corcoran et a 1. " "The Operator's Role and Safety Functions," Workshop-on-ticensiag and-Technical-Issues-Post-TMI;-Washington;-D:C:, March $9-12,1980$.

27. W. R. Neison, "Response Trees for Emergency Operator Action at the LOFT Facility," ANS/ENS-Topieal-Meeting-on-Thermal-Reactor-Safety, Knoxville, Tennessee, Apri1 7-11, 1980 .

28. W. R. Nelson, "Detection, Diagnosis, and Treatment of Accident Conditions in a Nuclear Facility," unpublished summary, EG\&G Idaho, Inc., August 1977.

29. Robert S. Ledley and Lee B. Lusted, "Reasoning Foundations of Medical Diagnosis," Science, 130, July 3, 195\%".

30. R. S. Ledley and L. B. Lusted, "The Use of Electronic Computers to. Aid in Medical Diagnosis," Proceedings of the.IRE, November 1959.

31. James C. Sisson et al., "Clinical Decision Analysis: The Hazard of Using Additional Data," Journat-of-the-American-Medical-Assoejation;-236, September 13, 1976. 
AP PENDIX A

DEFINITION OF TERMS 
Accident:

Assist:

Eharacteristic

Parameter:

Becision:

Detection:

Biagnosis:

Emergency Condition:

Mitigation:

Optima 1-Treatment:

Prevention:

Respond:

Safe Condition:

Treatment:

Symptoms:
Any occurrence which causes 1.) sufficient equipment damage to significantly delay restart of the reactor or 2.) release of significant radioactive materials beyond the confines of the containment building. To increase the probability of a satisfactory decision.

A parameter which can be monitored and used to diagnose system malfunctions.

A conscious choice to perform a specific action based on plant status.

To become aware of an emergency condition. The determination of plant status based on avajlable symptoms:

Any condition (defined by system parameters) which if not treated could result in an accident.

Treatment of an accident which results in a reduction of the consequences as compared to the case if no action is taken.

A satisfactory treatment which ranks highest according to predefined evaluation criteria. Treatment of an emergency condition such that the system is returned to a safe condition.

Includes the functions of detection, diagnosis, and treatment.

A stable condition (set of plant parameters) such that consequences will not increase unless further equipment or human errors occur.

An action which, when correctly performed, will return the system from an emergency condition to a safe condition.

The current values of all characteristic parameters. 
APPENDIX B

SYMBOLS AND ACRONYMS 
SYMBOLS

$\bowtie$ Manual Vaive (Normally open)

- Manual valve (Normally closed)

Valve Number
Control Valve

$\rightarrow \quad$ Check Varve
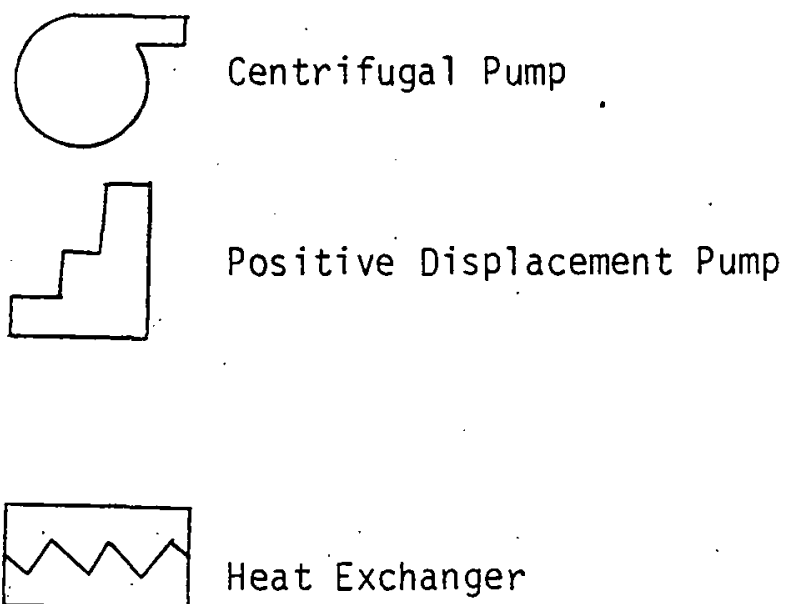

Heat Exchanger
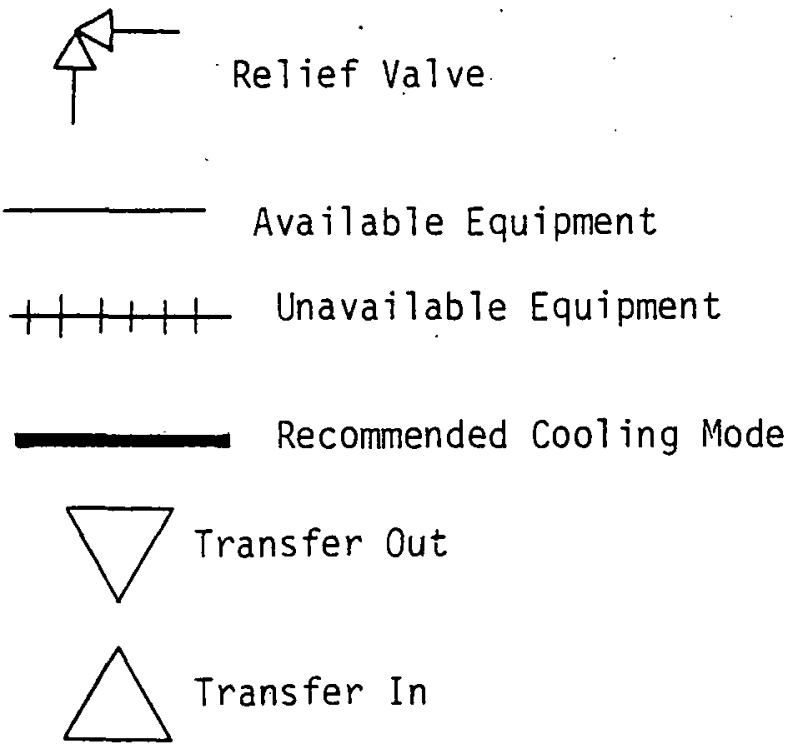
ACRON YMS

$\begin{array}{ll}\text { ACC. } & \text { Accumulator } \\ \text { ACC } & \text { Air Cooled Condenser } \\ \text { AFW } & \text { Auxiliary Feedwater } \\ \text { AOC } & \text { Augmented Operator Capability } \\ \text { BHL } & \text { Blowdown Hot Leg } \\ \text { BST } & \text { Blowdown Suppression Tank } \\ \text { BWST } & \text { Borated Water Storage Tank } \\ \text { CV } & \text { Control Valve } \\ \text { DHR } & \text { Decay Heat Removal } \\ \text { ECCS } & \text { Emergency Core Cooling System } \\ \text { FE } & \text { Flow Element } \\ \text { FI } & \text { Low Pressure Injection System } \\ \text { HPIS } & \text { Flow Indicator } \\ \text { HX } & \text { High Pressure Injection System } \\ \text { IX } & \text { Level Indicator } \\ \text { LC. } & \text { Leat Exchanger } \\ \text { LO } & \text { Lon Exchanger } \\ \text { LOCA } & \text { Locked Closed } \\ \text { LOCE } & \text { Lof }\end{array}$




$\begin{array}{ll}\text { MFW } & \text { Main Feedwater } \\ \text { NRC } & \text { Nuclear Regulatory Commission } \\ \text { NRHX } & \text { Non-Regenerative Heat Exchanger } \\ \text { PCS } & \text { Primary Coolant System } \\ \text { PI } & \text { Pressure Indicator } \\ \text { POM } & \text { Plant Operating Manual } \\ \text { PORV } & \text { Power Operated Relief Valve } \\ \text { P.R. Sump } & \text { Pressure Reduction Sump } \\ \text { QOBV } & \text { Quick Opening Blowdown Valve } \\ \text { SCS } & \text { Secondary Coolant System } \\ \text { TI } & \text { Temperature Indicator } \\ \text { TMI } & \text { Three Mile Island }\end{array}$


APPENDIX C

COMPONENT ATTRIBUTE TABLES 
TABLE $\quad$ - 1. PUMP ATTRIBUTE TABLE

\begin{tabular}{|c|c|c|c|c|}
\hline PUMP NUMBER & $\ldots \quad$ PUMP NAME & SYSTEM & … TYPE & POWER SUPPLY \\
\hline$P C-P-1$ & Primary Coolant \#1 & Primary Coolant & Centrifugal & Commercial \\
\hline$P C-P-2$ & Primary Coolant \#2 & Primary Coolant & Centrifugal & Commercial \\
\hline$S C-P-5$ & Main Feedwater & Secondary Coolant & Centrifugal & Commercial \\
\hline$S C-P-62 A$ & Auxiliary Feedwater & Secondary Coolant & Positive Displacement & Vital A \\
\hline$S C-P-62 B$ & Secondary Coolant Makeup & Secondary Coolant & Positive Displacement & Vital B \\
\hline$C P-P-1$ & Purification Pump & Purification & Centrifugal & Commercial \\
\hline$A C-P-4 A$ & HP IS Pump A & Addition and Control & Posit ive Displacement. & Vital A \\
\hline$A C-P-4 B$ & HPIS Pump B & Addition and Control & Positive Displacement & Vital B \\
\hline$E C C-P-64 A$ & LPIS Pump A & Emergency Core Cooling & Centrifugal & Vital A \\
\hline$E C C-P-64 B$ & LPIS Pump B & Emergency Core Cooling & Centrifugal & Vital B \\
\hline
\end{tabular}


TABLE C-2. VALVE ATtRIBUTE TABLE

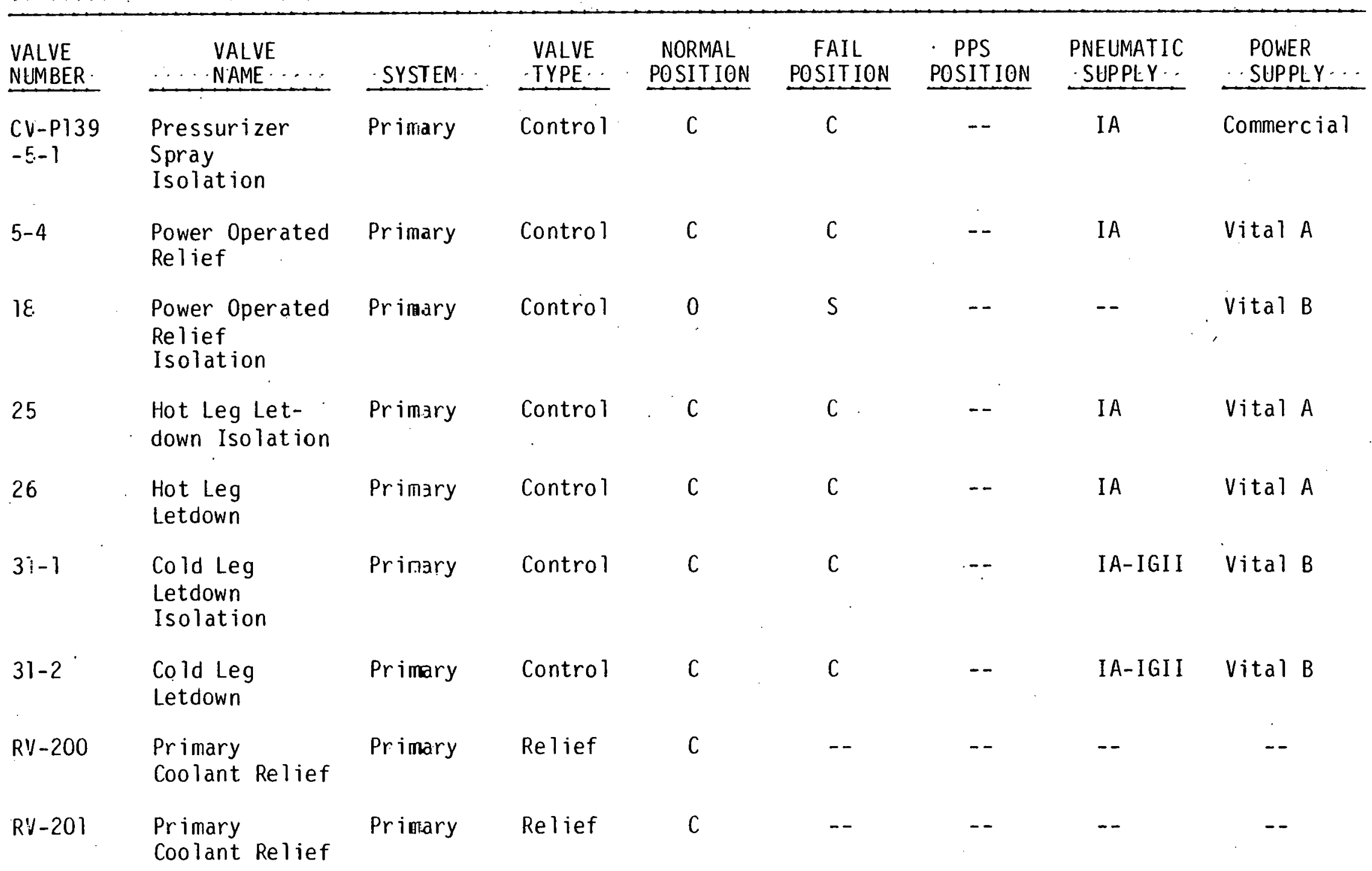


TABLE C-2. (Continued)

\begin{tabular}{|c|c|c|c|c|c|c|c|c|c|}
\hline $\begin{array}{l}\text { VALVE } \\
\text { NUMBER }\end{array}$ & $\begin{array}{r}\text { VALVE } \\
\cdots \quad \text { NAME } \\
\end{array}$ & 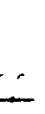 & SYSTEM & $\begin{array}{l}\text { VALVE } \\
\text { TYPE. } \\
\end{array}$ & $\begin{array}{c}\text { NORMAL } \\
\text { POSITION } \\
\end{array}$ & $\begin{array}{c}\text { FAIL } \\
\text { POSITION } \\
\end{array}$ & $\begin{array}{c}\text { PPS } \\
\text { POSITION } \\
\end{array}$ & $\begin{array}{l}\text { PNEUMATIC } \\
\text { SUPPEY } \\
\end{array}$ & $\begin{array}{l}\text { POWER } \\
\text { SUPPLY . } \\
\end{array}$ \\
\hline $\begin{array}{l}\mathrm{CV}-\mathrm{P4}- \\
8\end{array}$ & $\begin{array}{l}\text { Feed } \\
\text { Regulating }\end{array}$ & & Secondary & Control & 0 & $S$ & - & -- & Vital B \\
\hline 10 & $\begin{array}{l}\text { Steam Flow } \\
\text { Control }\end{array}$ & & Seccndary & Control & 0 & $S$ & -- & -- & Vital B \\
\hline 11 & $\begin{array}{l}\text { Main Steam } \\
\text { Stop }\end{array}$ & & Secondary & Control & 0 & $S$ & -- & -- & Vital B \\
\hline 73 & $\begin{array}{l}\text { Main } \\
\text { Feedwater } \\
\text { Isolation }\end{array}$ & , & Secondary & Control & 0 & 0 & -- & IA & Commercial \\
\hline 74 & $\begin{array}{l}\text { Auxiliary } \\
\text { Feedwater } \\
\text { Isolation }\end{array}$ & & Secondary & Control & $\mathrm{C}$ & 0 & -- & IA & Commercial \\
\hline $\begin{array}{l}C V-P 4 \\
-92\end{array}$ & $\begin{array}{l}\text { Bay } 1 \\
\text { Steam Inlet }\end{array}$ & & Secondary & Control & 0 & $S$ & $-\therefore$ & - & Commercial \\
\hline 93 & $\begin{array}{l}\text { Bay } 2 \\
\text { Steam Inlet }\end{array}$ & & Secondary & Control & 0 & $S$ & -- & -- & Commercial \\
\hline 94 & $\begin{array}{l}\text { Bay } 3 \\
\text { Steam Inlet }\end{array}$ & & Secondary & Control & 0 & $S$ & -- & -- & Commercial \\
\hline 95 & $\begin{array}{l}\text { Bay } 1 \\
\text { Condensate } \\
\text { Discharge }\end{array}$ & & Secondary & Control & 0 & $S$ & - & $\therefore$ & Commercial \\
\hline
\end{tabular}


TABLE C-2. (Continued)

\begin{tabular}{|c|c|c|c|c|c|c|c|c|}
\hline $\begin{array}{l}\text { VALVE } \\
\text { NUMBER } \\
\end{array}$ & $\begin{array}{l}\text { VALVE } \\
\text { NAME } \\
\end{array}$ & SYSTEM & $\begin{array}{l}\text { VALVE } \\
\text { TYPE } \\
\end{array}$ & $\begin{array}{c}\text { NORMAL } \\
\text { POSITION } \\
\end{array}$ & $\begin{array}{c}\text { FAIL } \\
\text { POSITION } \\
\end{array}$ & $\begin{array}{c}\text { PPS } \\
\text { POSITION } \\
\end{array}$ & $\begin{array}{l}\text { PNEUMATIC } \\
\text { SUPPLY } \\
\end{array}$ & $\begin{array}{l}\text { POWER } \\
\text { SUPPLY }\end{array}$ \\
\hline \multicolumn{9}{|l|}{$\mathrm{CV}-\mathrm{P} 4-$} \\
\hline 96 & $\begin{array}{l}\text { Bay } 2 \\
\text { Condensate } \\
\text { Discnarge }\end{array}$ & Secondary & Control & 0 & $S$ & -- & -- & Commercial \\
\hline 97 & $\begin{array}{l}\text { Bay } 3 \\
\text { Condensate } \\
\text { Discharge }\end{array}$ & Secondary & Control & 0 & $S$ & -- & -- & Commercial \\
\hline 131 & $\begin{array}{l}\text { Aux FW } \\
\text { Makeup Tie }\end{array}$ & Secondary & Control & C & 0 & -- & IA & Vital B \\
\hline$V-553$ & $\begin{array}{l}\text { DW Storage } \\
\text { Tank B Out let } \\
\text { Isolation }\end{array}$ & $\begin{array}{l}\text { Demin. } \\
\text { Water }\end{array}$ & Manual & 0 & -- & -- & -- & -- \\
\hline$V-554$ & $\begin{array}{l}\text { DW Storage } \\
\text { Tank A Outlet } \\
\text { Isolation }\end{array}$ & $\begin{array}{l}\text { Demin. } \\
\text { Water }\end{array}$ & Manual & 0 & -- & -- & -- & -- \\
\hline$v-1766$ & $\begin{array}{l}\text { Aux Feed Pump } \\
\text { Suction } \\
\text { Isolation }\end{array}$ & $\begin{array}{l}\text { Demirn. } \\
\text { Weter }\end{array}$ & Manual & 0 & -- & -- & -- & -- \\
\hline$V-1767$ & $\begin{array}{l}\text { Makeup Pump } \\
\text { Suction. } \\
\text { Isolation }\end{array}$ & $\begin{array}{l}\text { Demin. } \\
\text { Wéter }\end{array}$ & Manual & 0 & -- & -- & -- & -- \\
\hline$V-1770$ & $\begin{array}{l}\text { Aux Feed Pump } \\
\text { Discharge } \\
\text { Isolation }\end{array}$ & Secondary & Manual & 0 & -- & -- & -- & -- \\
\hline$V-1771$ & $\begin{array}{l}\text { Makeup Pump } \\
\text { Discharge } \\
\text { Isolation }\end{array}$ & Secondary & Manual & 0 & - & -- & -- & -- \\
\hline
\end{tabular}


TABLE C-2. (Continued)

\begin{tabular}{|c|c|c|c|c|c|c|c|c|}
\hline $\begin{array}{l}\text { VALVE } \\
\text { NUMBER } \\
\end{array}$ & $\begin{array}{l}\text { VALVE } \\
\text { NAME } \\
\end{array}$ & SYSTEM & $\begin{array}{l}\text { VALVE } \\
\text { TYPE } \\
\end{array}$ & $\begin{array}{c}\text { NORMAL } \\
\text { POSITION } \\
\end{array}$ & $\begin{array}{c}\text { FAIL } \\
\text { POSITION } \\
\end{array}$ & $\begin{array}{c}\text { PPS } \\
\text { POSITION } \\
\end{array}$ & $\begin{array}{l}\text { PNEUMATIC } \\
\text { SUPPLY } \\
\end{array}$ & $\begin{array}{l}\text { POWER } \\
\text { SUPPLY }\end{array}$ \\
\hline V-1773 & $\begin{array}{l}\text { DW to } \\
\text { Secondary } \\
\text { Makeup Inlet }\end{array}$ & $\begin{array}{l}\text { Demin. } \\
\text { Water }\end{array}$ & Manual & 0 & -- & - & -- & -- \\
\hline$V-3050$ & -- & Secondary & Check & -- & -- & -- & -- & -- \\
\hline$V-5000$ & -- & Secondary & Cneck & - & - & -- & -- & -- \\
\hline$V-6531$ & $\begin{array}{l}\text { DW-L-16 } \\
\text { Inlet } \\
\text { Isolation }\end{array}$ & $\begin{array}{l}\text { Demin. } \\
\text { Wé:-er }\end{array}$ & Manual & 0 & -- & -- & -- & -- \\
\hline$v-6371$ & - & Secondary & Cneck & -- & -- & -- & - & - \\
\hline$V-358$ & $\begin{array}{l}\text { Main Feed } \\
\text { Pump Suction } \\
\text { Isolation }\end{array}$ & SEcondary & Manual & 0 . & - & - & -- & -- \\
\hline$v-410$ & -- & -- & Check & - & -- & - & -- & - \\
\hline V-6532 & $\begin{array}{l}\text { DW-L-16 } \\
\text { Discharge } \\
\text { Isolation }\end{array}$ & $\begin{array}{l}\text { Denin. } \\
\text { Water }\end{array}$ & Manual & 0 & -- & - & -- & - \\
\hline$V-5083$ & $\begin{array}{l}\text { DW-L-16 and } \\
\text { DW-L-19 } \\
\text { Combined } \\
\text { Isolation }\end{array}$ & $\begin{array}{l}\text { Deritin. } \\
\text { Water }\end{array}$ & Manual & 0 & - & -- & -- & -- \\
\hline $\begin{array}{l}C V-P 140 \\
-1\end{array}$ & $\begin{array}{l}\text { Purfication } \\
\text { IX Bypass }\end{array}$ & $\begin{array}{l}\text { Purifi- } \\
\text { cation }\end{array}$ & Control & c & 0 & - & IA & Commercial \\
\hline
\end{tabular}


TABLE C-2. (Continued)

\begin{tabular}{|c|c|c|c|c|c|c|c|c|}
\hline $\begin{array}{l}\text { V.ALVE } \\
\text { NUMBER. }\end{array}$ & $\begin{aligned} & \text { VALVE } \\
& \cdots \quad \text { NAME } \\
&\end{aligned}$ & SYSTEM & $\begin{array}{l}\text { VALVE } \\
\text { TYPE } \\
\end{array}$ & $\begin{array}{l}\text { NORMAL } \\
\text { POSITION } \\
\end{array}$ & $\begin{array}{c}\text { FAIL } \\
\text { POSITION } \\
\end{array}$ & $\begin{array}{c}\text { PPS } \\
\text { POSITION } \\
\end{array}$ & $\begin{array}{l}\text { PNEUMATIC } \\
\text { SUPPLY } \\
\end{array}$ & $\begin{array}{l}\text { POWER } \\
\text { SUPPLY . }\end{array}$ \\
\hline CV-P140- & & & & & & & & \\
\hline-7 & $\begin{array}{l}\text { Regenerative } \\
\mathrm{HX} \text { She } 11 \text { Side } \\
\text { In iet }\end{array}$ & $\begin{array}{l}\text { Purifi- } \\
\text { cation }\end{array}$ & Control & 0 & C & $-=$ & IA & Commercial \\
\hline-5 & $\begin{array}{l}\text { Purification } \\
\text { Flow Control }\end{array}$ & $\begin{array}{l}\text { Purifi- } \\
\text { cation }\end{array}$ & Control & 0 & 0 & -- & IA & Commercial \\
\hline-6 & $\begin{array}{l}\text { Purification } \\
\text { Outlet } \\
\text { Isolation }\end{array}$ & $\begin{array}{l}\text { Purifi- } \\
\text { cation }\end{array}$ & Control & 0 & $c$ & -- & IA & Commercial \\
\hline$-B$ & $\begin{array}{l}\text { Purification } \\
\text { Inlet Stop }\end{array}$ & $\begin{array}{l}\text { Purifi- } \\
\text { cation }\end{array}$ & Control & 0 & $\mathrm{C}$ & -- & IA & Commercial \\
\hline-9 & $\begin{array}{l}\text { Purification } \\
\text { Inlet } \\
\text { Isolation }\end{array}$ & $\begin{array}{l}\text { Purifi- } \\
\text { cation }\end{array}$ & Control. & 0 & $\mathrm{C}$ & - & IA & Commercial \\
\hline$V-4053$ & $\begin{array}{l}\text { Purification } \\
\text { Filter Inlet }\end{array}$ & $\begin{array}{l}\text { Purifi- } \\
\text { cation }\end{array}$ & Manual & 0 & - & -- & -- & -- \\
\hline$V-4056$ & $\begin{array}{l}\text { Purification } \\
\text { IX Inlet }\end{array}$ & $\begin{array}{l}\text { Purifi- } \\
\text { cation }\end{array}$ & Manual & 0 & - & -- & -- & -- \\
\hline$V-4060$ & -- & $\begin{array}{l}\text { Purifi- } \\
\text { cation }\end{array}$ & Check & -- & -- & -- & - & -- \\
\hline $\begin{array}{l}C V-P 120 \\
-32\end{array}$ & $\begin{array}{l}\text { Accumulator } \\
\text { 'B' Discharge } \\
\text { Stop }\end{array}$ & ECCS & Control & 0 & 0 & 0 & $I A-I G I I$ & Vital B \\
\hline
\end{tabular}


TABLE C-2. (Continued)

\begin{tabular}{|c|c|c|c|c|c|c|c|c|}
\hline $\begin{array}{l}\text { VALVE } \\
\text { NUMBER }\end{array}$ & $\begin{aligned} & \text { VALVE } \\
& \ldots \quad \text { NAME . . . } \\
&\end{aligned}$ & SYSTEM & $\begin{array}{l}\text { VALVE } \\
\text { TYPE }\end{array}$ & $\begin{array}{c}\text { NORMAL } \\
\text { POSITION } \\
\end{array}$ & $\begin{array}{c}\text { FAIL } \\
\text { POSITION } \\
\end{array}$ & $\begin{array}{c}\text { PPS } \\
\text { POSITION } \\
\end{array}$ & $\begin{array}{l}\text { PNEUMATIC } \\
\text { SUPPLY } \\
\end{array}$ & $\begin{array}{l}\text { POWER } \\
\text { SUPPLY }\end{array}$ \\
\hline CV-P120- & & & & & & & & \\
\hline 35 & $\begin{array}{l}\text { Accumulator } \\
\text { 'B' Discharge } \\
\text { Isolation }\end{array}$ & ECCS & Control & 0 & 0 & 0 & $I A-I G I I$ & Vital B \\
\hline 47 & $\begin{array}{l}\text { Accumulator } \\
\text { 'A' Discharge } \\
\text { Stop }\end{array}$ & ECCS & Control & 0 & 0 & 0 & IA & Vital A \\
\hline 510 & $\begin{array}{l}\text { Accumulator } \\
\text { 'A' Discharge } \\
\text { Isolation }\end{array}$ & ECC & Control & 0 & 0 & 0 & IA & Vital A \\
\hline 63 & $\begin{array}{l}\text { ECC to } \\
\text { Cold Leg } \\
\text { Isolation }\end{array}$ & ECCE & Contror & c & 0 & 0 & $I G-I$ & Vital A \\
\hline 6.6 & $\begin{array}{l}\text { ECC to Lower } \\
\text { Plenum } \\
\text { Isolation }\end{array}$ & ECCS & Control & 0 & 0 & 0 & $I G-I$ & Vital A \\
\hline 90 & $\begin{array}{l}\text { LPIS ' } A \text { ' and } \\
\text { ACC ' } A \text { ' to } \\
\text { Cold Leg } \\
\text { Isolation }\end{array}$ & ECCS & Control & C & C & c & $I G-I$ & Vital A \\
\hline 109 & $\begin{array}{l}\text { ECC to Down- } \\
\text { comer } x \text {-t ie } \\
\text { Isolation }\end{array}$ & ECC & Control & C & 0 & 0 & IG-I I & Vital B \\
\hline 110 & $\begin{array}{l}\text { ECC to } \\
\text { Downcomer } \\
\text { Isolation }\end{array}$ & ECCs & Control & 0 & 0 & 0 & IG-II & Vital $B$ \\
\hline
\end{tabular}


TABLE C-2. (Continued)

\begin{tabular}{|c|c|c|c|c|c|c|c|c|}
\hline $\begin{array}{l}\text { VALVE } \\
\text { NUMBER }\end{array}$ & $\begin{array}{l}\text { VALVE } \\
\text { NAME }\end{array}$ & SYSTEM & $\begin{array}{l}\text { VALVE } \\
\text { TYPE. } \\
\end{array}$ & $\begin{array}{c}\text { NORMAL } \\
\text { POSITION } \\
\end{array}$ & $\begin{array}{c}\text { FAIL } \\
\text { POSITION } \\
\end{array}$ & $\begin{array}{c}\text { PPS } \\
\text { POSITION } \\
\end{array}$ & $\begin{array}{r}\text { PNEUMATIC } \\
\text { SUPPLY } Y \\
\end{array}$ & $\begin{aligned} & \text { POWER } \\
& \therefore \text { SUPPLY } \\
&\end{aligned}$ \\
\hline$V-2164$ & -- & ECCS & Check & - & -- & -- & -- & - \\
\hline$V-2165$ & -- & ECCS & Check & -- & -- & -- & -- & -- \\
\hline$V-2167$ & -- & ECCS & Check & -- & - & -- & -- & -- \\
\hline$V-2169$ & -- & ECCS & Check & -- & -- & -- & -- & -- \\
\hline$v-2170$ & -- & ECCS & Check & -- & -- & -- & - & -- \\
\hline $\begin{array}{l}\mathrm{Cl}-\mathrm{P} 128- \\
\mathrm{I}\end{array}$ & $\begin{array}{l}\text { BWST to } \\
\text { Charging } \\
\text { Pump A }\end{array}$ & $\begin{array}{l}\text { Addi=ion } \\
\text { and } \\
\text { Contmol }\end{array}$ & Control & C & 0 & 0 & IA & Vital $A$ \\
\hline 14 & $\begin{array}{l}\text { BWST to } \\
\text { Charging } \\
\text { Pump B }\end{array}$ & $\begin{array}{l}\text { Add tion } \\
\text { and } \\
\text { Control }\end{array}$ & Control & C & 0 & 0 & IA-IGII & Vital B \\
\hline 105 & $\begin{array}{l}\text { Charging } \\
\text { Pump B } \\
\text { Discharge } \\
\text { Crosstie }\end{array}$ & $\begin{array}{l}\text { Addition } \\
\text { and } \\
\text { Control }\end{array}$ & Control & C & C & C & IA-IGII & Vital B \\
\hline 109 & $\begin{array}{l}\text { Charging } \\
\text { Pump A } \\
\text { Discharge } \\
\text { Crosstie }\end{array}$ & $\begin{array}{l}\text { Addition } \\
\text { and } \\
\text { Con:rol }\end{array}$ & Control & C & C & C & IA & Vital A \\
\hline 116. & $\begin{array}{l}\text { Chargirg } \\
\text { Pump B } \\
\text { Di scharge }\end{array}$ & $\begin{array}{l}\text { Addition } \\
\text { and } \\
\text { Control }\end{array}$ & Control & 0 & 0 & 0 & IA-IGII & Vital $B$ \\
\hline
\end{tabular}


TABLE C-2. (Continued)

\begin{tabular}{|c|c|c|c|c|c|c|c|c|}
\hline $\begin{array}{l}\text { VALVE } \\
\text { NUMBER . } \\
\end{array}$ & $\begin{array}{c}\text { VALVE } \\
\text { NAME } \ldots . . \\
\end{array}$ & SYSTEM & $\begin{array}{l}\text { VALVE } \\
\text { TYPE } \\
\end{array}$ & $\begin{array}{l}\text { NORMAL } \\
\text { POSITION }\end{array}$ & $\begin{array}{c}\text { FAIL } \\
\text { POSITION } \\
\end{array}$ & $\begin{array}{c}\text { PPS } \\
\text { POSITIION }\end{array}$ & $\begin{array}{l}\text { PNEUMATIC } \\
\text { SUPPLY } \\
\end{array}$ & $\begin{array}{l}\text { POWER } \\
\text { SUPPEY } \\
\end{array}$ \\
\hline \multicolumn{9}{|l|}{ CV-P128- } \\
\hline 117 & $\begin{array}{l}\text { Charging } \\
\text { Pump A } \\
\text { Discharge }\end{array}$ & $\begin{array}{l}\text { Addition } \\
\text { and } \\
\text { Control }\end{array}$ & Control & 0 & 0 & 0 & IA & Vital A \\
\hline$V-2222$ & $\begin{array}{l}\text { Charging } \\
\text { Pump A } \\
\text { Suction }\end{array}$ & $\begin{array}{l}\text { Addition } \\
\text { and } \\
\text { Control }\end{array}$ & Manual & 0 & -- & -- & -- & -- \\
\hline$V-2224$ & $\begin{array}{l}\text { Charging } \\
\text { Pump B } \\
\text { Suction }\end{array}$ & $\begin{array}{l}\text { Addition } \\
\text { and } \\
\text { Control }\end{array}$ & Manual & 0 & -- & -- & -- & -- \\
\hline$V-2253$ & $\begin{array}{l}\text { Charging } \\
\text { Pump A } \\
\text { Discharge }\end{array}$ & $\begin{array}{l}\text { Addition } \\
\text { and } \\
\text { Contropl }\end{array}$ & Manual & 0 & -- & -- & -- & -- \\
\hline$V-2255$ & $\begin{array}{l}\text { Charging } \\
\text { Pump B } \\
\text { Discharge }\end{array}$ & $\begin{array}{l}\text { Addition } \\
\text { and } \\
\text { Control }\end{array}$ & Manual & 0 & -- & - & - & -- \\
\hline$V-3042$ & -- & $\begin{array}{l}\text { Addition } \\
\text { and } \\
\text { Control }\end{array}$ & Check & -- & -- & -- & -- & -- \\
\hline$V-3043$ & -- & $\begin{array}{l}\text { Addition } \\
\text { and } \\
\text { Control }\end{array}$ & Check & -- & - & -- & -- & -- \\
\hline$V-5134$ & -- & $\begin{array}{l}\text { Addition } \\
\text { and } \\
\text { Control }\end{array}$ & Check & -- & -- & -- & -- & -- \\
\hline
\end{tabular}


TABLE C-2. (Continued)

\begin{tabular}{|c|c|c|c|c|c|c|c|c|}
\hline $\begin{array}{l}\text { VALVE } \\
\text { NUMBER . } \\
\end{array}$ & $\begin{array}{r}\text { VALVE } \\
\ldots \text { NAME . . } \\
\end{array}$ & SYSTEM. & $\begin{array}{l}\text { VALVE } \\
\text { TYPE } \\
\end{array}$ & $\begin{array}{l}\text { NORMAL } \\
\text { POSITION }\end{array}$ & $\begin{array}{c}\text { FAIL } \\
\text { POSITION } \\
\end{array}$ & $\begin{array}{c}\text { PPS } \\
\text { POSITION } \\
\end{array}$ & $\begin{array}{l}\text { PNEUMATIC } \\
\text { SUPPLY } \\
\end{array}$ & $\begin{array}{l}\text { POWER } \\
\text { SUPPLY . . }\end{array}$ \\
\hline$V-6474$ & -- & $\begin{array}{l}\text { Addition } \\
\text { and } \\
\text { Control }\end{array}$ & Check & -- & -- & -- & -- & - \\
\hline$V-5225$ & $\begin{array}{l}\text { BWST to } \\
\text { Charging } \\
\text { Pumps Suction }\end{array}$ & $\begin{array}{l}\text { Addition } \\
\text { and } \\
\text { Control }\end{array}$ & Manual & LO & -- & -- & -- & - \\
\hline $\begin{array}{l}C V-P 120 \\
-52 A\end{array}$ & $\begin{array}{l}\text { BWST to LPIS } \\
\text { Pump Header } \\
\text { Isolation }\end{array}$ & $\operatorname{ECCS}$ & Control & 0 & 0 & 0 & IA & Vital A \\
\hline$-52 B$ & $\begin{array}{l}\text { BWST to LPIS } \\
\text { Pump Header } \\
\text { Isolation }\end{array}$ & $\operatorname{ECC} 5$ & Contro' & 0 & 0 & 0 & IA & Vital B \\
\hline$-57-1$ & $\begin{array}{l}\text { Blowdown Loop } \\
\text { to LPIS } \\
\text { Isolation }\end{array}$ & ECCS & Control & C & C & -- & $I G-I$ & Commercial \\
\hline$-67-2$ & $\begin{array}{l}\text { Blowdown Loop } \\
\text { to LPIS Stop }\end{array}$ & ECCS & Control & C & C & -- & $I G-I$ & Commercial \\
\hline$-70-1$ & $\begin{array}{l}\text { LPIS 'B' } \\
\text { Discharge Stop }\end{array}$ & ECCS & Control & 0 & 0 & 0 & $I G-I I$ & Vital B \\
\hline$-71-1$ & $\begin{array}{l}\text { LPIS 'A' } \\
\text { Discharge Stop }\end{array}$ & ECCS & Control & 0 & 0 & 0 & IG-I & Vital A \\
\hline-76 & $\begin{array}{l}\text { LPIS ' } B \text { ' } \\
\text { Suction from } \\
\text { BWST }\end{array}$ & ECCs & Control & 0 & 0 & 0 & IA-IGI I & Vital B \\
\hline
\end{tabular}


TABLE C-2. (Continued)

\begin{tabular}{|c|c|c|c|c|c|c|c|c|}
\hline $\begin{array}{l}\text { VALVE } \\
\text { NUMBER. }\end{array}$ & $\begin{array}{r}\text { VALVE } \\
\ldots \text { NAME } \\
\end{array}$ & SYSTEM & $\begin{array}{l}\text { VALVE } \\
\text { TYPE. } \\
\end{array}$ & $\begin{array}{c}\text { NORMAL } \\
\text { POSITION } \\
\end{array}$ & $\begin{array}{c}\text { FAIL } \\
\text { POSITION } \\
\end{array}$ & $\begin{array}{c}\text { PPS } \\
\text { POSITION } \\
\end{array}$ & $\begin{array}{l}\text { PNEUMATIC } \\
\text { SUPPLY } \\
\end{array}$ & $\begin{aligned} & \text { POWER } \\
& \text { S SUPPLY . . . } \\
&\end{aligned}$ \\
\hline CV-P120- & & & & & & & & \\
\hline-77 & $\begin{array}{l}\text { LPIS ' } B \text { ' } \\
\text { Suction from } \\
\text { P.R. Sump }\end{array}$ & ECCS & Control & $c$ & C & $c$ & $I A-I G I I$ & Vital B \\
\hline-78 & $\begin{array}{l}\text { LPIS 'A' } \\
\text { Suction from } \\
\text { P.R. Sump }\end{array}$ & ECCS & Control & C & C & C & IA & Vital A \\
\hline-79 & $\begin{array}{l}\text { LPIS 'B' } \\
\text { Suct ion from } \\
\text { Blowdown Loop }\end{array}$ & ECCS & Control & C & $c$ & $C$ & $I A-I G I I$ & Vital $B$ \\
\hline-80 & $\begin{array}{l}\text { LPIS 'A' } \\
\text { Suction from } \\
\text { Blowdown Loop }\end{array}$ & ECCS & Control & C & C & C & IA & Vital A \\
\hline-81 & $\begin{array}{l}\text { LPIS 'A' } \\
\text { Suction from } \\
\text { BWST }\end{array}$ & ECCS & Control & 0 & 0 & 0 & IA & Vital A \\
\hline-97 & $\begin{array}{l}\text { LPIS 'A' } \\
\text { Discharge } \\
\text { Isolation }\end{array}$ & ECCS & Control & $\dot{c}$ & 0 & 0 & $I G-I$ & Vital A \\
\hline-107 & $\begin{array}{l}\text { LPIS ' } B \text { ' } \\
\text { Discharge } \\
\text { x-tie Isolation }\end{array}$ & ECCS & Control & C & 0 & 0 & IA-IGI I & Vital B \\
\hline-108 & $\begin{array}{l}\text { LPIS 'A' } \\
\text { Discharge } \\
\text { X-tie Isolation }\end{array}$ & $E C \subset$ & Control & C & 0 & 0 & IA-IGI I & Vital A \\
\hline
\end{tabular}


TABLE C-2. (Continued)

\begin{tabular}{|c|c|c|c|c|c|c|c|c|}
\hline $\begin{array}{l}\text { VALVE } \\
\text { NUMBER }\end{array}$ & $\begin{array}{l}\text { VALVE } \\
\text { NAME . . . } \\
\end{array}$ & SYSTEM & $\begin{array}{l}\text { VALVE } \\
\text { TYPE } \\
\end{array}$ & $\begin{array}{l}\text { NORMAL } \\
\text { POSITION } \\
\end{array}$ & $\begin{array}{c}\text { FAIL } \\
\text { POSITION }\end{array}$ & $\begin{array}{c}\text { PPS } \\
\text { POSITION } \\
\end{array}$ & $\begin{array}{l}\text { PNEUMATIC } \\
\text { SUPPLY } \\
\end{array}$ & $\begin{array}{r}\text { POWER } \\
\text { SUPPLY } \\
\end{array}$ \\
\hline \multicolumn{9}{|c|}{ CV-P120- } \\
\hline-719 & $\begin{array}{l}\text { LPIS 'B' } \\
\text { Discharge } \\
\text { Isolation }\end{array}$ & ECCS & Control & C & 0 & - & IG-I I & Vital B \\
\hline-73 & $\begin{array}{l}\text { LPIS 'B' } \\
\text { Flow Control }\end{array}$ & $\mathrm{ECCS}$ & Control & 0 & 0 & 0 & IA-IGII & Vital B \\
\hline-84 & $\begin{array}{l}\text { LPIS 'A' } \\
\text { Flow Control }\end{array}$ & ECCS & Control & 0 & 0 & 0 & IA & Vital B \\
\hline$v-2155$ & $\begin{array}{l}\text { LPIS 'B' } \\
\text { Discharge } \\
\text { Drain }\end{array}$ & ECCs & Manual & LC & -- & -- & - & -- \\
\hline$v-2156$ & $\begin{array}{l}\text { LPIS 'A' } \\
\text { Discharge } \\
\text { Drain }\end{array}$ & ECCS & Manual & LC & -- & -- & - & -- \\
\hline$v-2160$ & -- & ECCS & Check & -- & - & -- & -- & -- \\
\hline$v-2161$ & -- & ECCS & Check & -- & -- & -- & -- & -- \\
\hline$y-2162$ & -- & ECC. & Check & -- & -- & -- & -- & -- \\
\hline$V-2163$ & -- & ECCS & Check & -- & -- & -- & -- & -- \\
\hline$V-2356$ & -- & ECCS & Check & -- & -- & -- & -- & -- \\
\hline$v-5180$ & - & ECC: & Check & -- & -- & -- & -- & -- \\
\hline$v-5832$ & $\begin{array}{l}\text { BWST to LPIS } \\
\text { Isolation }\end{array}$ & ECCS & Manual & LO & -- & -- & -- & -- \\
\hline
\end{tabular}


TABLE C-2. (Continued)

\begin{tabular}{|c|c|c|c|c|c|c|c|c|}
\hline $\begin{array}{l}\text { VAL VE } \\
\text { NUMBER }\end{array}$ & $\begin{array}{r}\text { VALVE } \\
\cdots \text { NAME } . \\
\end{array}$ & SYSTEM & $\begin{array}{l}\text { VALVE } \\
\text { TYPE }\end{array}$ & $\begin{array}{c}\text { NORMAL } \\
\text { POSI TION } \\
\end{array}$ & $\begin{array}{c}\text { FAIL } \\
\text { POSITION } \\
\end{array}$ & $\begin{array}{c}\text { PPS } \\
\text { POSITION }\end{array}$ & $\begin{array}{l}\text { PNEUMATIC } \\
\text { SUPPLY. } \\
\end{array}$ & $\begin{aligned} & \text { POWER } \\
&- \text { SUPPLY. } \\
&\end{aligned}$ \\
\hline$v-5849$ & - & EC.CS: & Check & -- & -- & - & - & - \\
\hline$V-5850$ & -- & ECCS & Check & -- & - & -- & -- & -- \\
\hline $\begin{array}{l}C V-P 138 \\
-7\end{array}$ & $\begin{array}{l}\text { Cold Leg } \\
\text { QOBV }\end{array}$ & Bloudown & Control & C & C & - & - & Commercial \\
\hline-2 & $\begin{array}{l}\text { Blowdown Cold } \\
\text { Leg Isolation }\end{array}$ & Blowdown & Control & C & $S$ & - & - & Commercial \\
\hline-15 & Hot Leg QOBV & Blowdown & Control & C & C & -- & -- & Commercial \\
\hline-16 & $\begin{array}{l}\text { Blowdown Hot } \\
\text { Leg Isolation }\end{array}$ & Bloudown & Control & C & $S$ & - & - & Commercial \\
\hline-30 & $\begin{array}{l}\text { Suppression } \\
\text { tank drain to } \\
\text { sump bypass }\end{array}$ & Blowdown & Control & C & C & - & IA & Vital B \\
\hline-31 & $\begin{array}{l}\text { Suppression } \\
\text { tank drain } \\
\text { to sump }\end{array}$ & Blondown & Control & C & C & -- & IA & Vital A \\
\hline-70 & $\begin{array}{l}\text { Reflood Assist } \\
\text { Bypass 'A' }\end{array}$ & Blowdown & Control & C & S & 0 & - & Vital A \\
\hline-71 & $\begin{array}{l}\text { Reflood Assist } \\
\text { Bypass 'B' }\end{array}$ & Blcwdown & Control & C & $S$ & 0 & - & Vital B \\
\hline
\end{tabular}


APPENDIX D

COMPONENT LEVEL RESPONSE TREES 

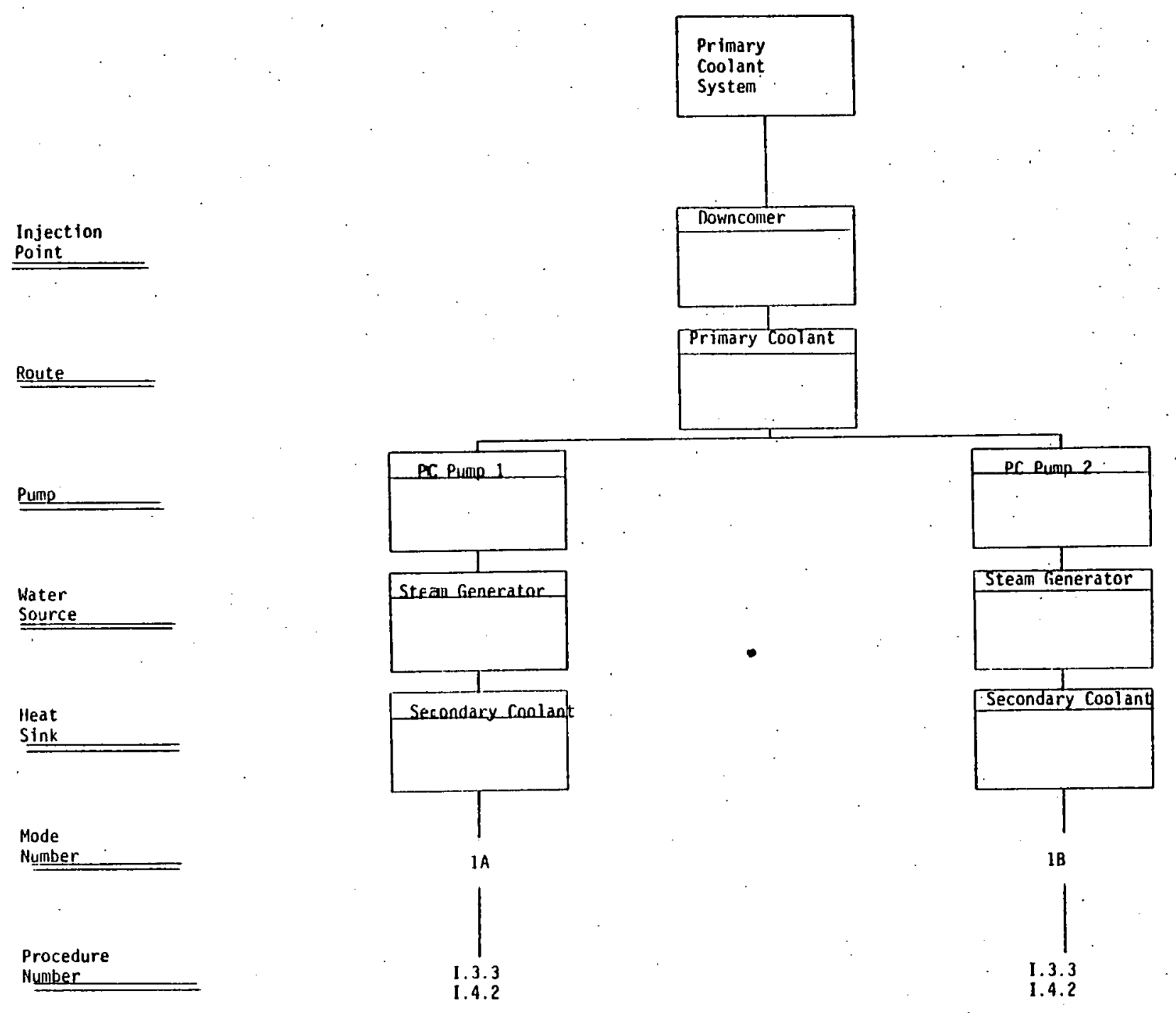
Injection

Point.

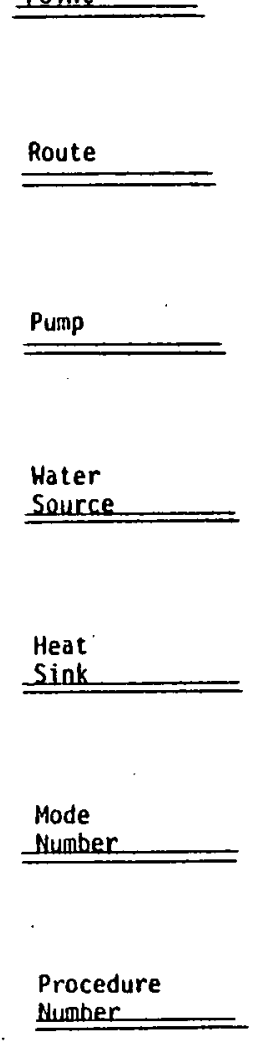

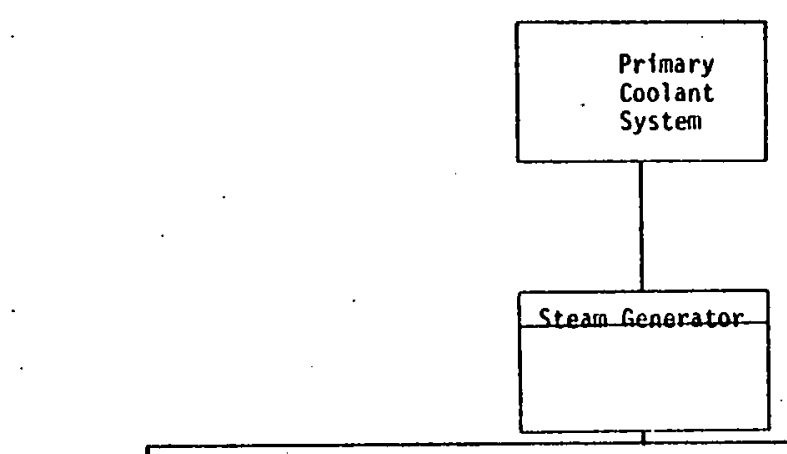

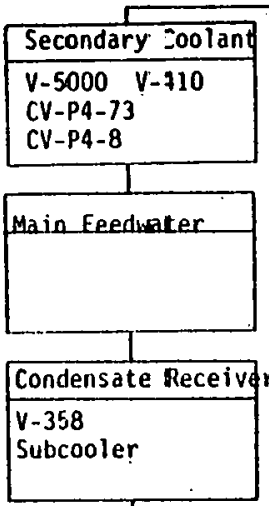

Air Coolec Conden er

\section{CV-P4-10}

CV-P4-1
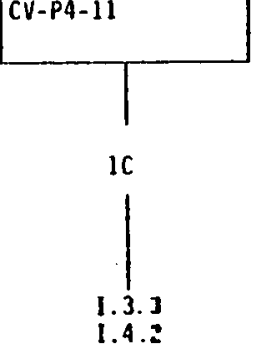

AuxTrary Feedwat r
$V-3050$
CV-P4-74
$V-6371$

Auxillary Feedwat or

$v-1770$

$v-1766$

Demin. Hater

$v=5085-v=1773$

$v-6532$ v -553 or

$n-6 .-12$
$y-6531$

Air Cooled Conden er

CV-P4-10
CV-P4-11

1.5 .8

1.5.16 scis Makeup

CV-P4-131

$V-1771$

V-6371

Demin. Water

$v=5083 \quad v=1773$

$V-6532 \quad V-553$ or

NW-L-16

$v-6531$

Air Cooled Condenser

CV-P4-10
CV-P4-11 
Injection

Point

Point

Route

Pump

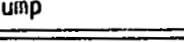

Water

Source

$=$

Heat
Sink

Sink

Mode

Mode
Number

Procedure

Number.

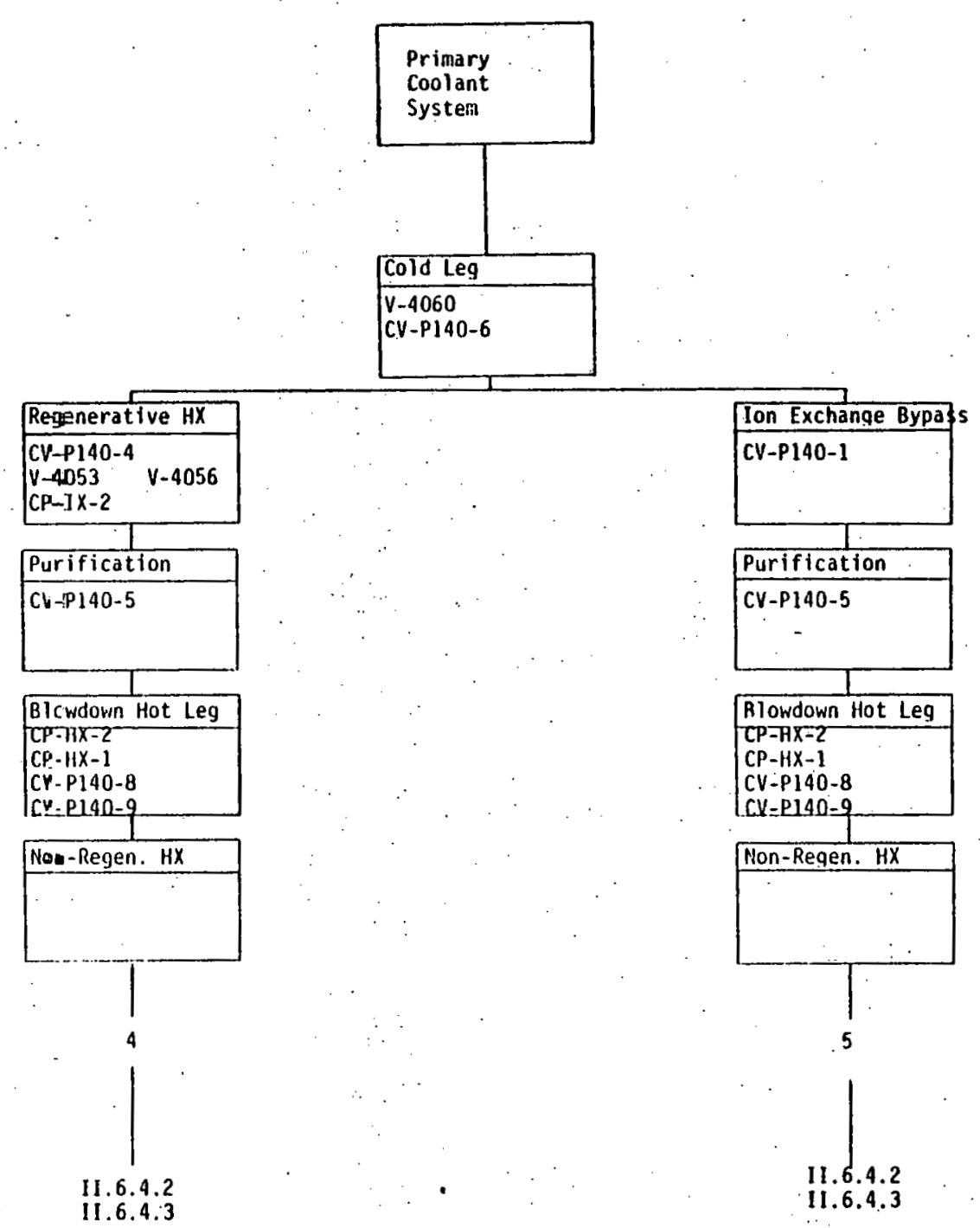




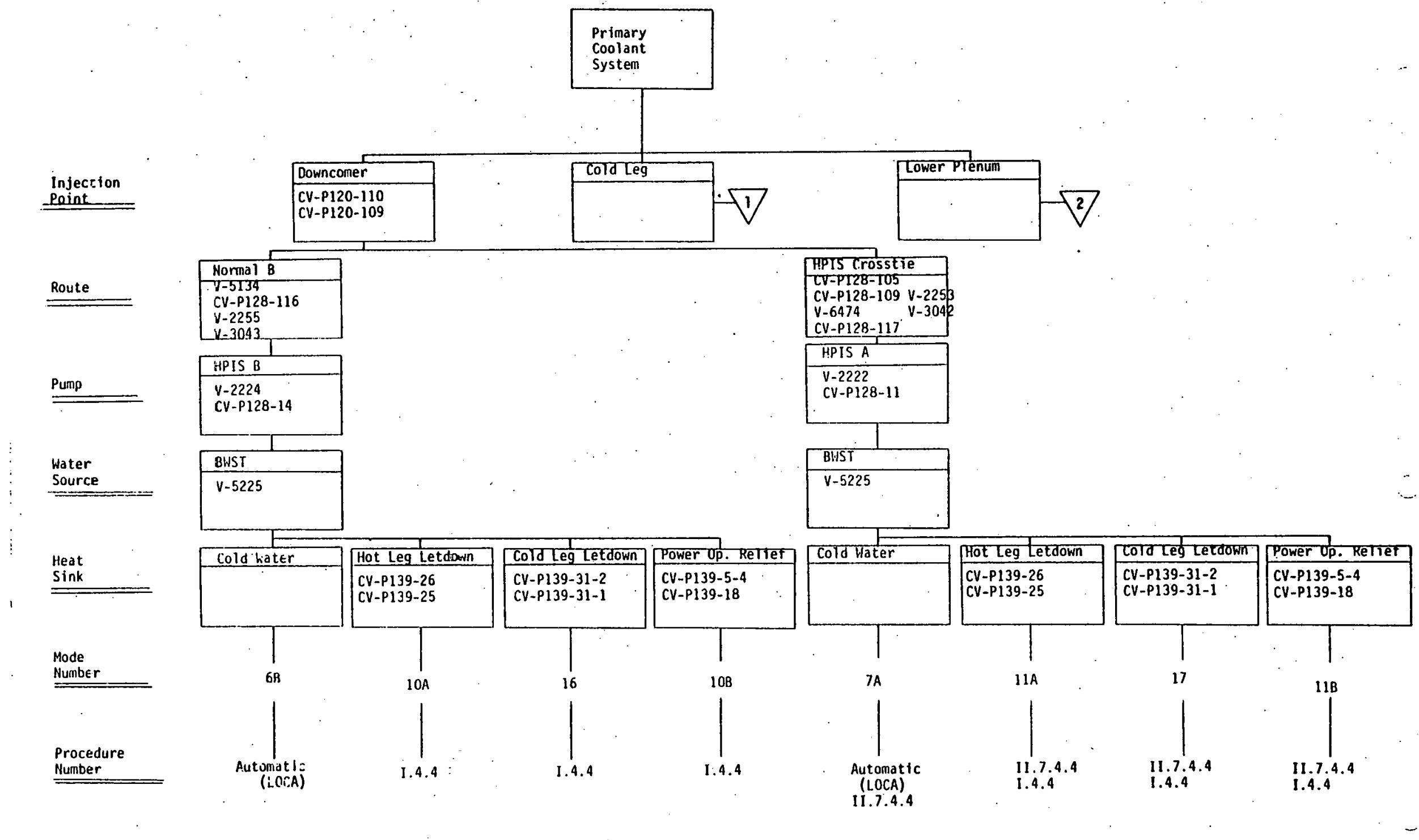


Injection

Point

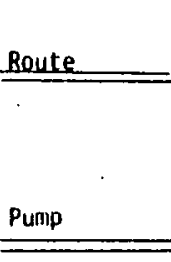

Water

Source

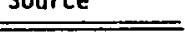

Heat
Sink

Sink

Mode

Number

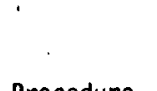

Procedure

Number

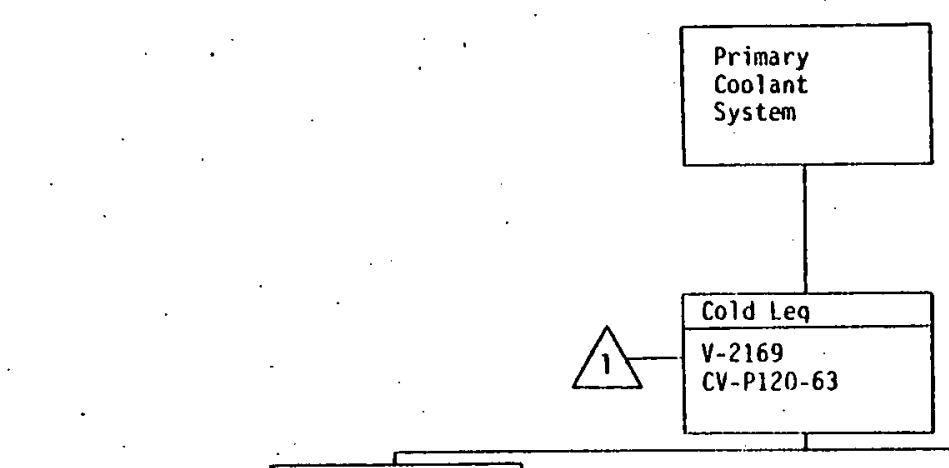

\begin{tabular}{|c|}
\hline Normal $A$ \\
\hline $\begin{array}{l}V-6474 \quad V-3042 \\
C V-P 128-11 ? \\
V-2253\end{array}$ \\
\hline HPIS A \\
\hline $\begin{array}{l}V-2222 \\
C V-P 128-11\end{array}$ \\
\hline \\
\hline BWST \\
\hline$v-5225$ \\
\hline
\end{tabular}

Hot Lea Letdown

\section{CV-P139-26}

CV-P139-25

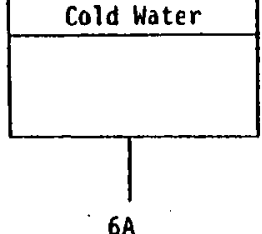

$6 A$

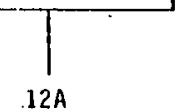

Power 0p. Relief

\section{CV-P139-5-4}

CV-P139-18

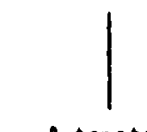

Autoniatic
(LOCA)

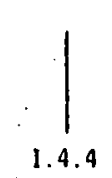

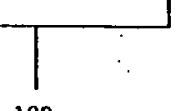

$12 B$

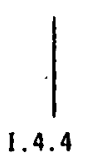

HPIS Crosst

CV-P128-109 V-225

CV-P128-105 V-304

$\mathrm{V}-5134$

CK-P128-116
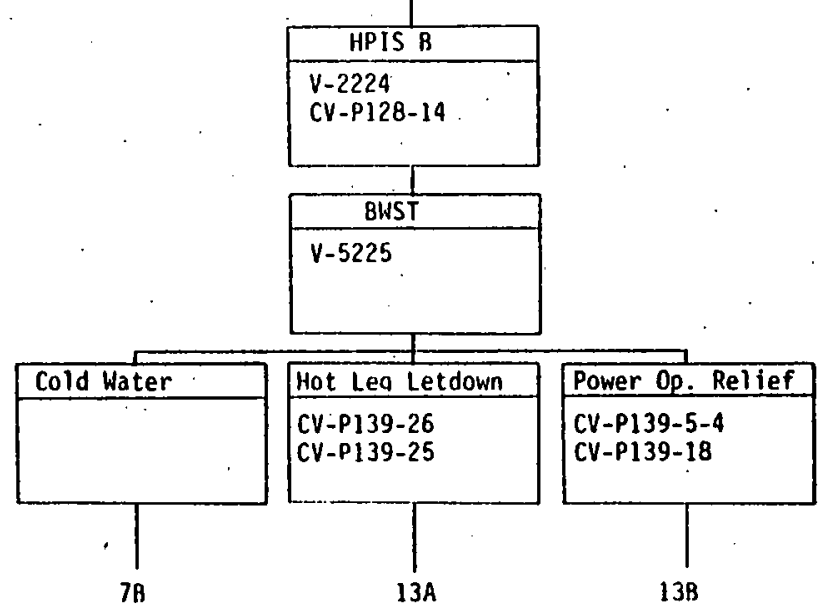

CV-P139-26

CV-P139-5-4

CV-P139-18

$13 \mathrm{~A}$

13B

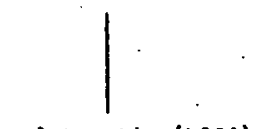

Automatic (LOCA)

II. 7.4.4

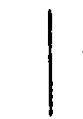

II.7.4.9.

$1.4 .4^{4}$

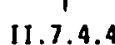

II.7.4.4 


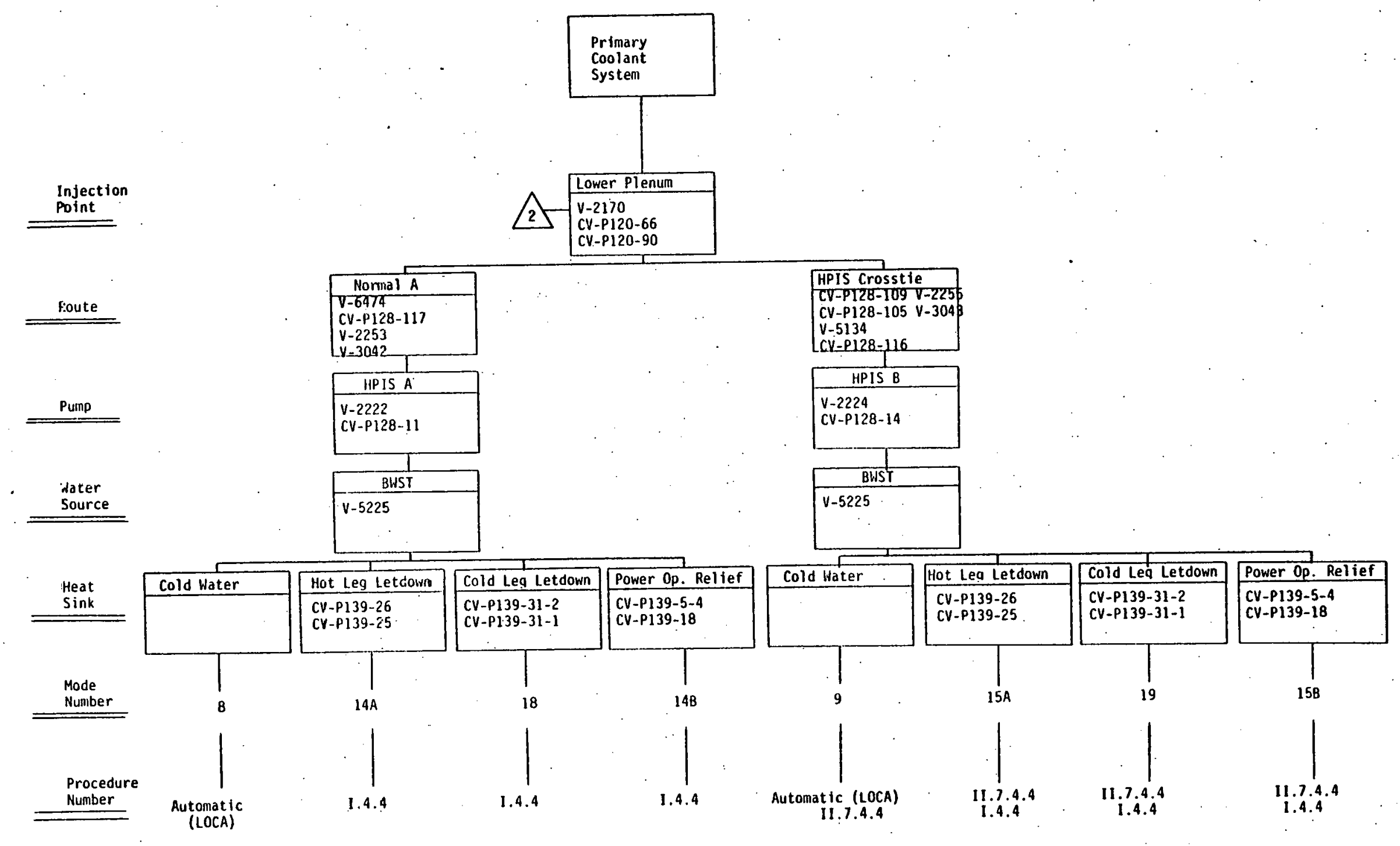



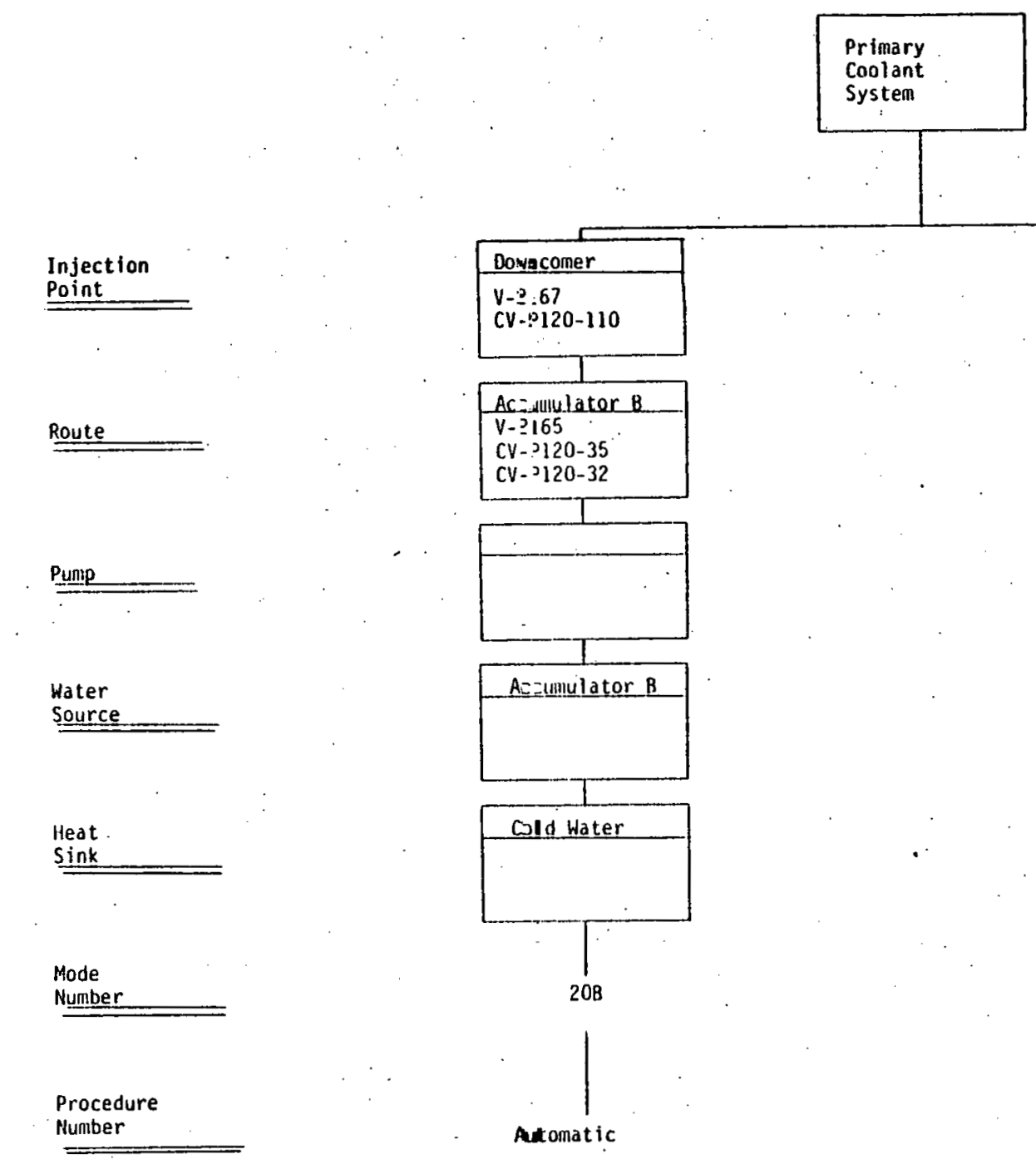

Coolant

System
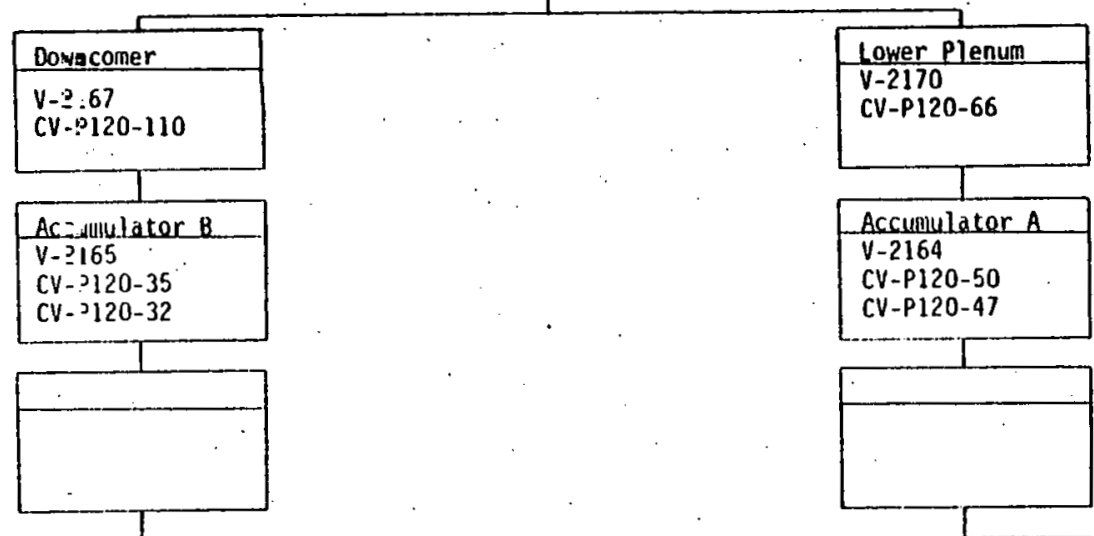

CV-P120-50

CV-P120-47

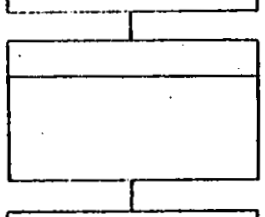

Ac-umulator $B$

Accumulator A
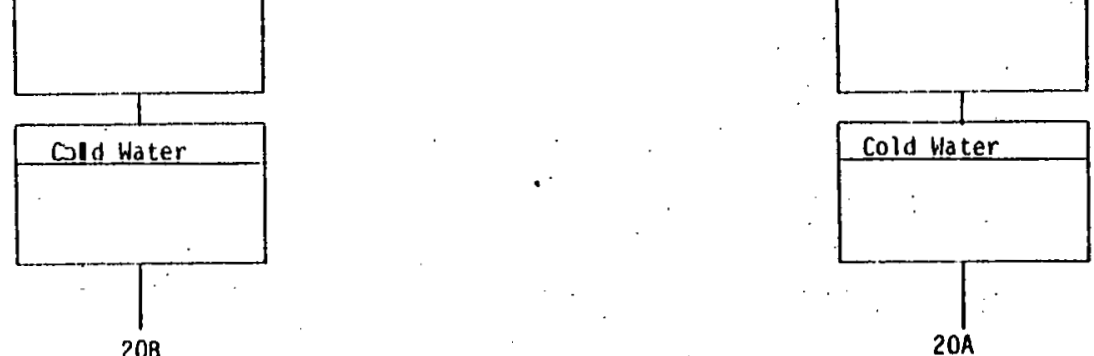

ב.

Atomatic

Automatic 


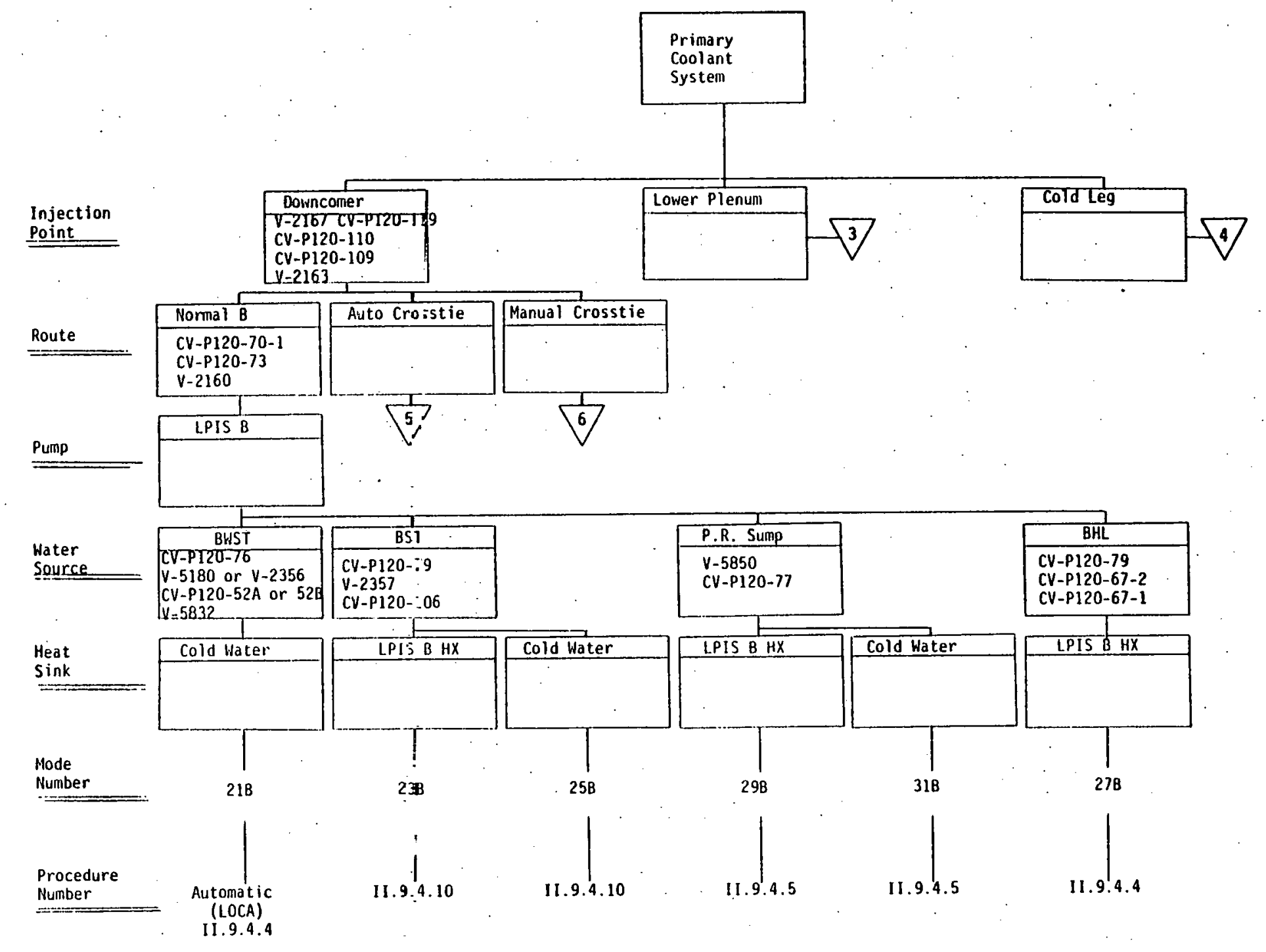




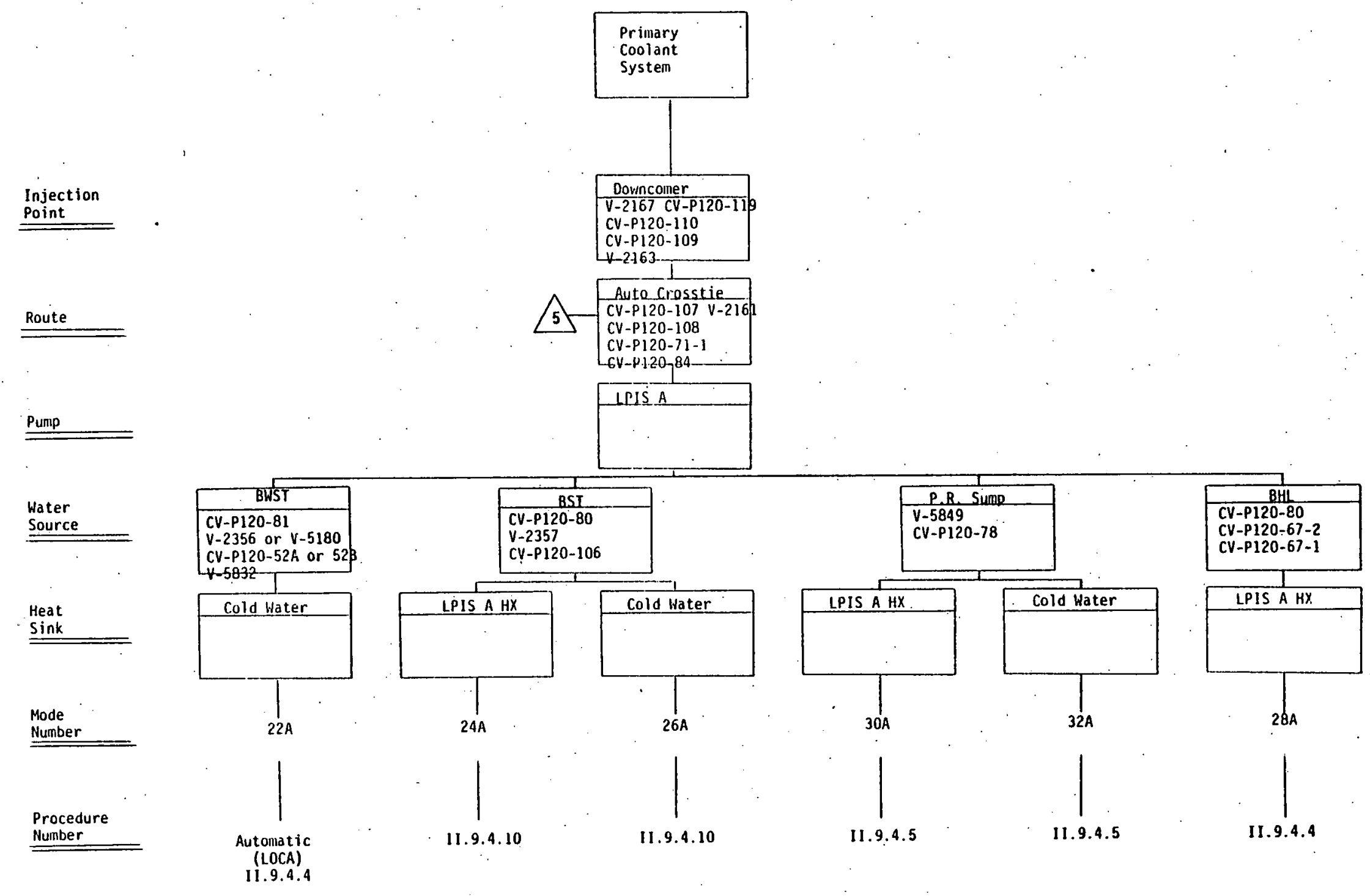


Injection

Point

Route

Pump

Water

Source

Heat

Sink

Mode

Number

Procedure

Number
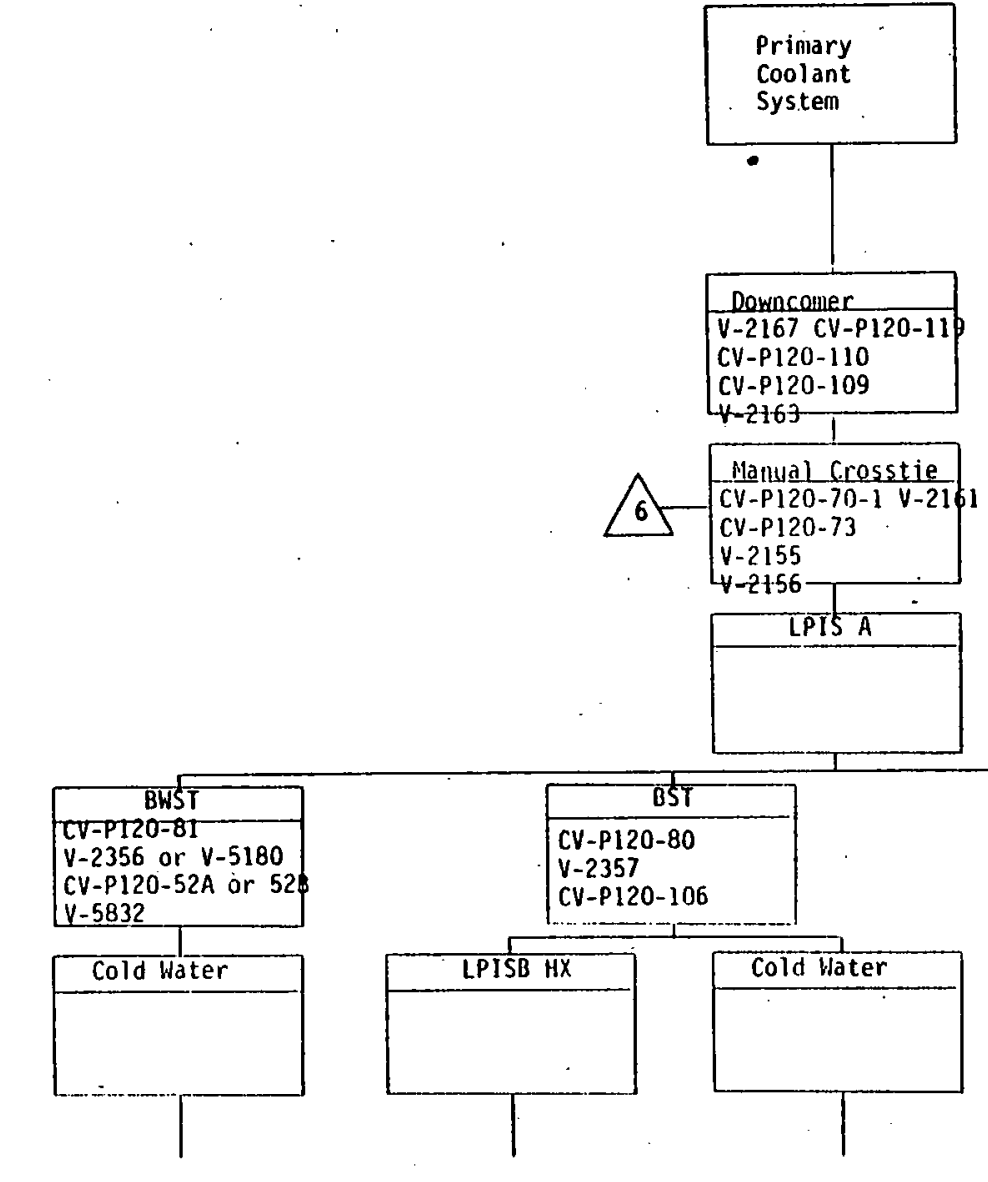

$45 \mathrm{~A}$

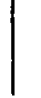

Automatic (LOCA)

II. 9.4 .4
II. 9.4 .9
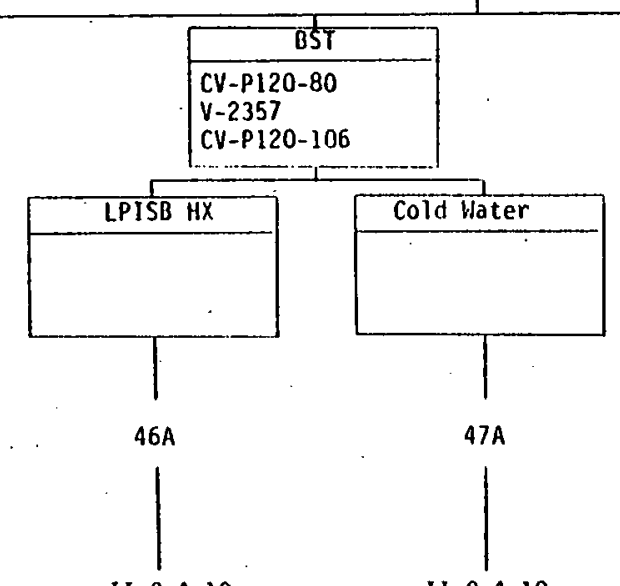

I. 9.4 .10

11.9.4.9
$47 \mathrm{~A}$

II. 9.4 .10

II.9.4.10
II. 9.4 .9

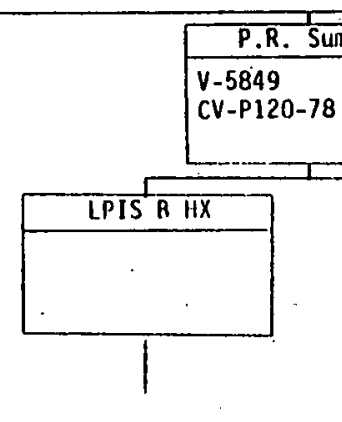

$49 A$

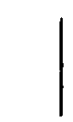

II.9.4.5

II.9.4.9

$-5849$
V-P120-78

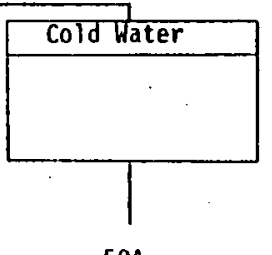

$50 \mathrm{~A}$

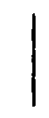

11.9 .4 .5
11.9 .4 .9
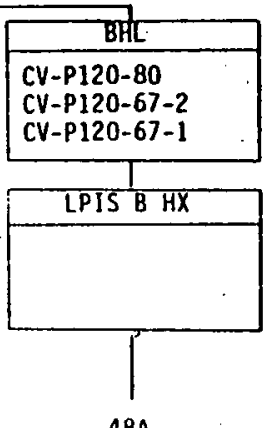

$48 \mathrm{~A}$

11.9 .4 .4 


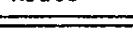

Pump

Route

Water

Source

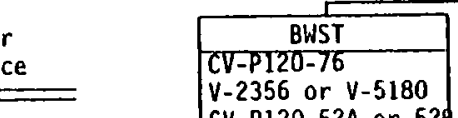

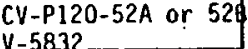

Heat

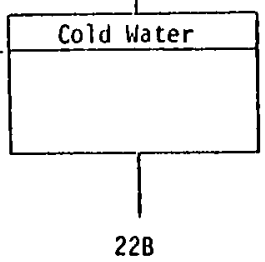

Mode

Number

Procedure Number

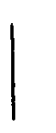

Automatic (LOCA)

II. 9.4.4

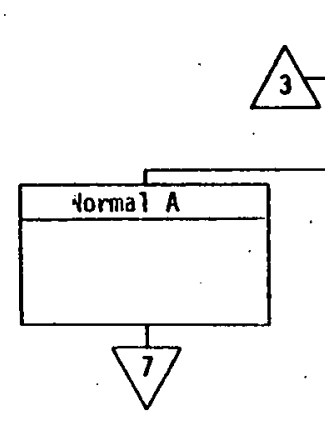

Lower Plenum

$V-2170$

CV-P120-66

\section{Auto Crosstie}

Auto Crosstie Manual Crosstie

CV-P120-97 CV-P12申-73
CV

CV-P120-108 V-216

$\mathrm{CV}=\mathrm{P} 120=0 \mathrm{OZ}$
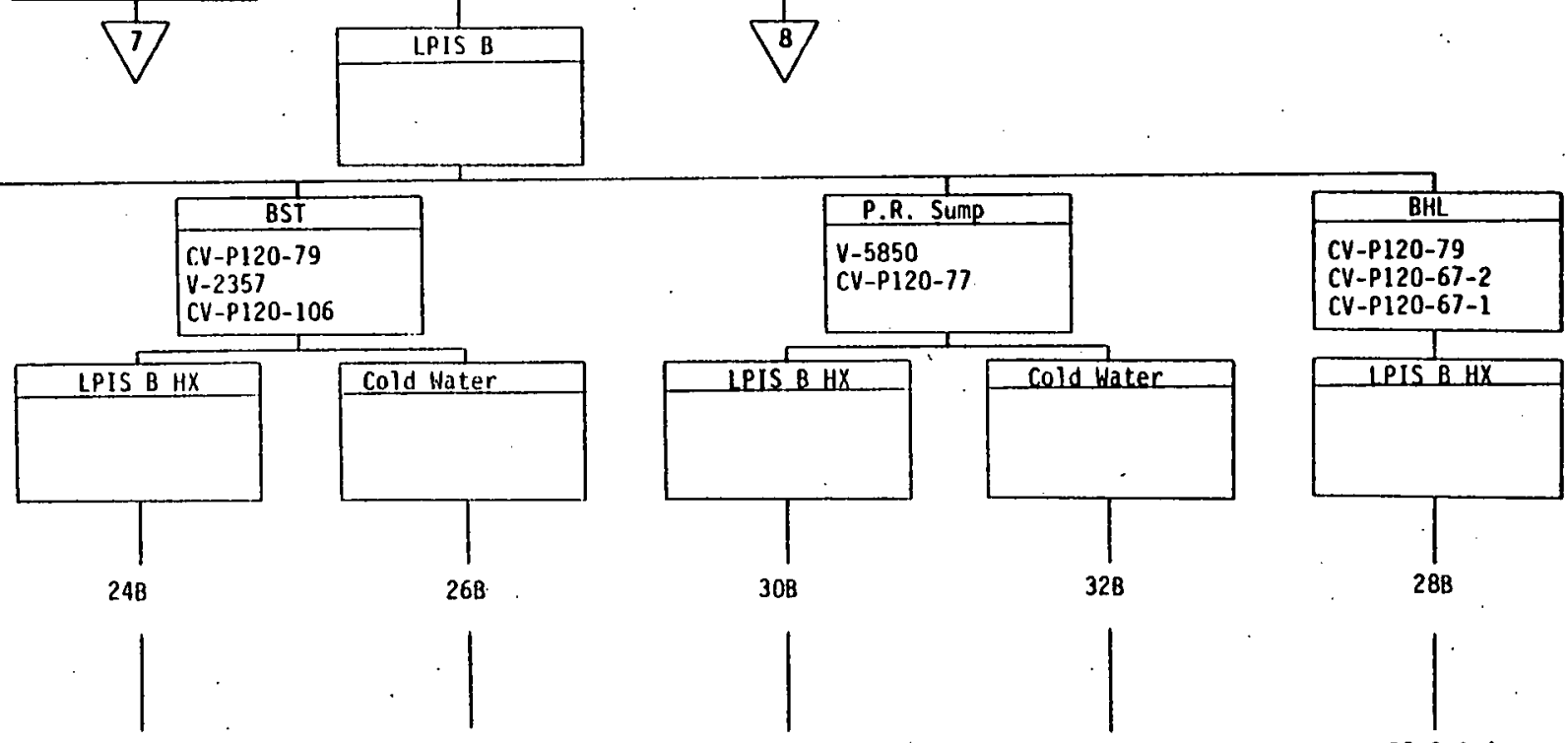

CV-P120-67-1

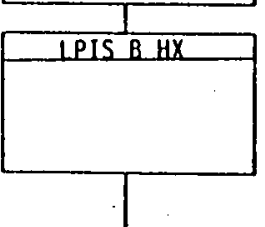

$28 \mathrm{~B}$

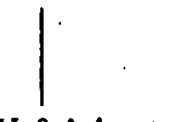

II.9.4.4 


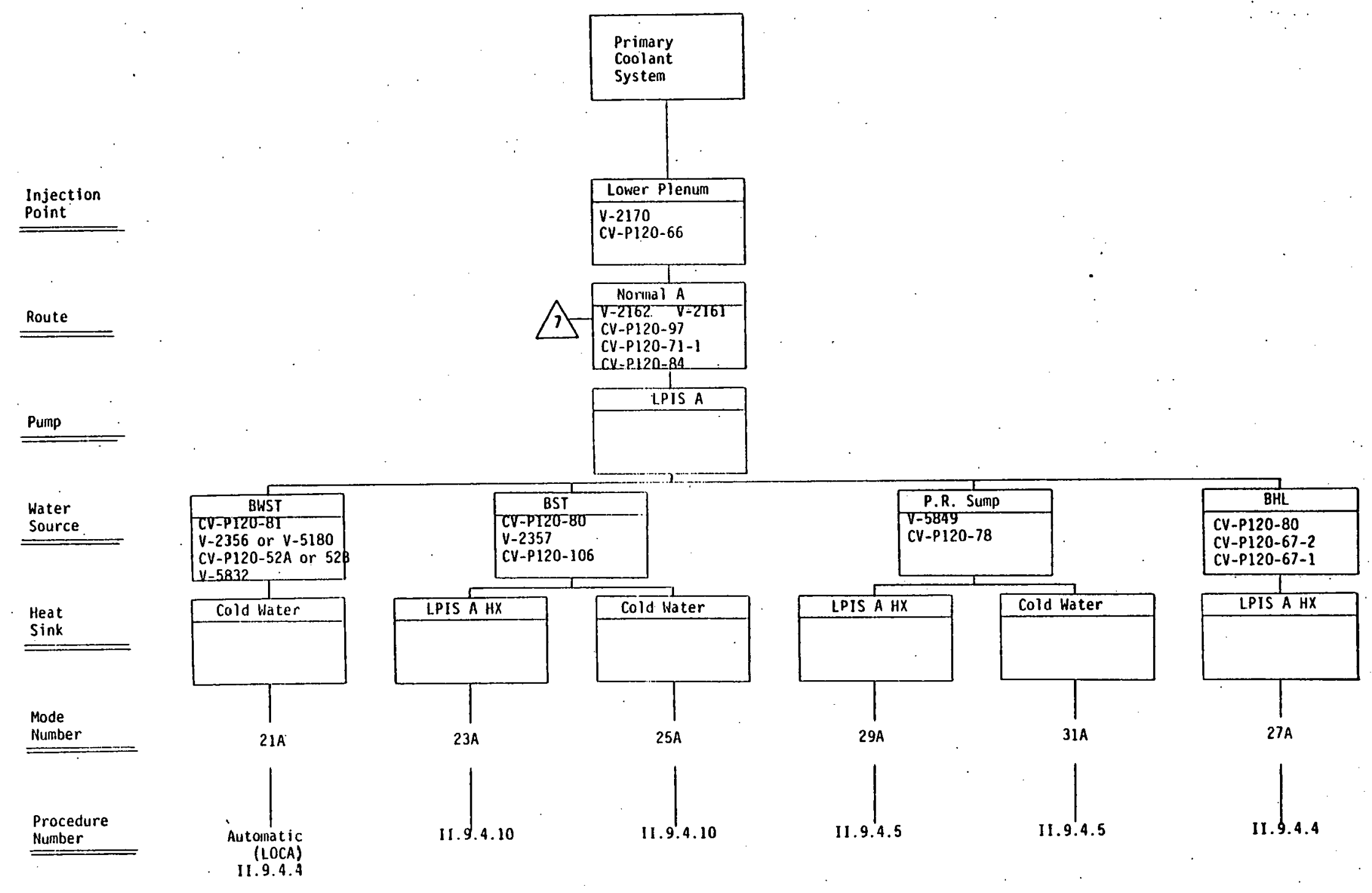


Injection

Point

Route

Punip

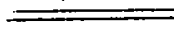

Water

\begin{tabular}{ll|} 
Source & \multicolumn{1}{c}{ CV-P120-76 } \\
\cline { 2 - 2 } & $\mathrm{V}-2356$ or $V-5180$ \\
\hline
\end{tabular}

$V-2356$ or $V-5180$
CV-P120-52A or $52 B$

$V-5832$
$V$

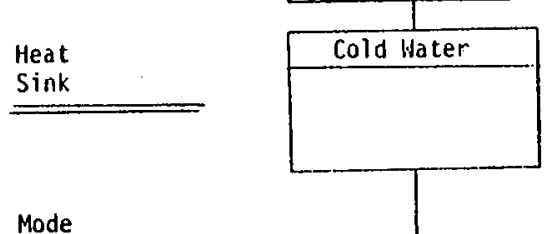

Number

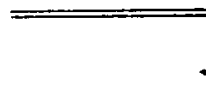

Procedure

Number
$=$
(LOCA)

$$
\text { (LOCA) }
$$

I1. 9.4 .9

Primary

Coolant

System

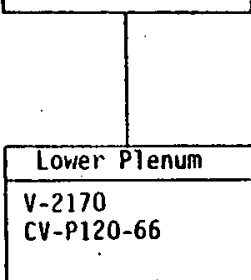

\begin{tabular}{|lr|}
\hline & Manual \\
\hline$V-2162$ & Crosstie \\
\hline CV-P120-97 & $V-2156$ \\
\hline
\end{tabular}

CV-P120-71-1 $V-2100$

CV-P120-71-1 V-21
CV-P120-84

CV-P120-84
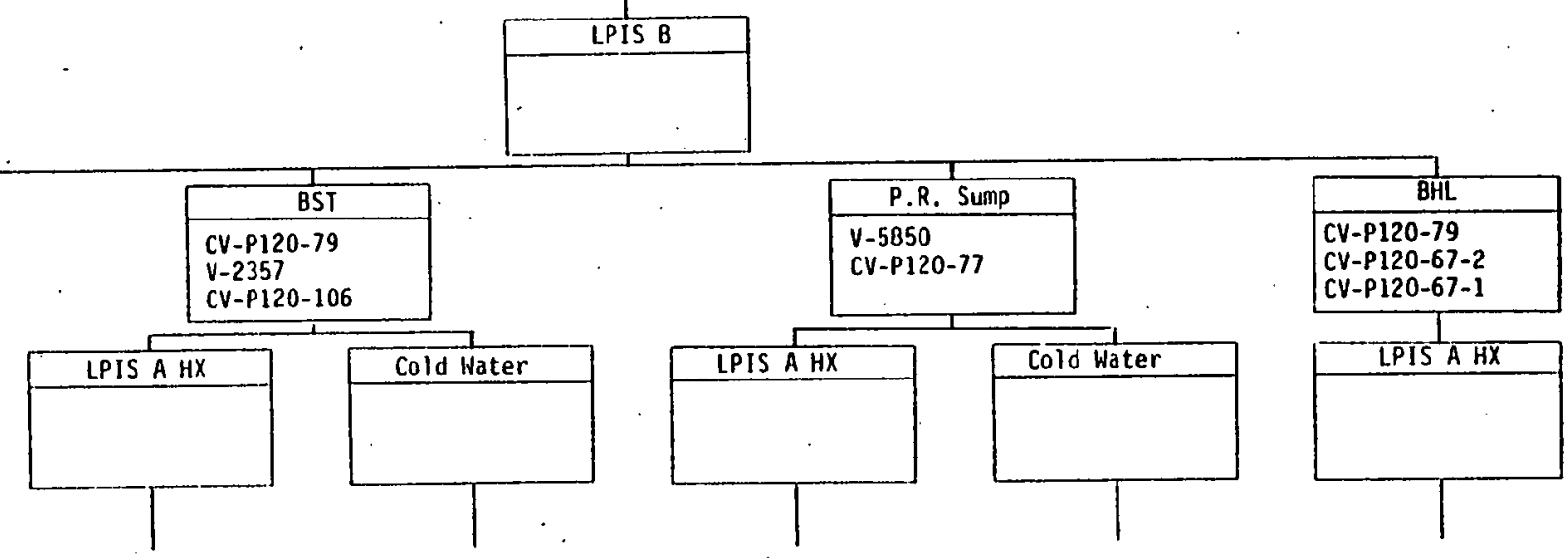

498

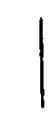

II. $9 \cdot 4 \cdot 10$

11.9 .4 .9
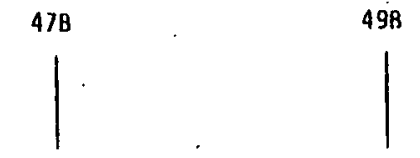

II. 9.4 .5

II. 9.4 .10
II. 9.4 .9

11.9 .4 .9

$50 B$

48B

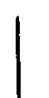

$\begin{array}{rr}11.9 .4 .5 & 11.9 .4 .4 \\ \text { Ii. } 9.4 .9 & 11.9 .4 .9\end{array}$ 
Injection

Point

Route

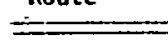

Pump

Pusp

Water

Source

Source

Heat
Sink

$\underline{ }$

Mode

Number

$=$

Procedure

Huniber

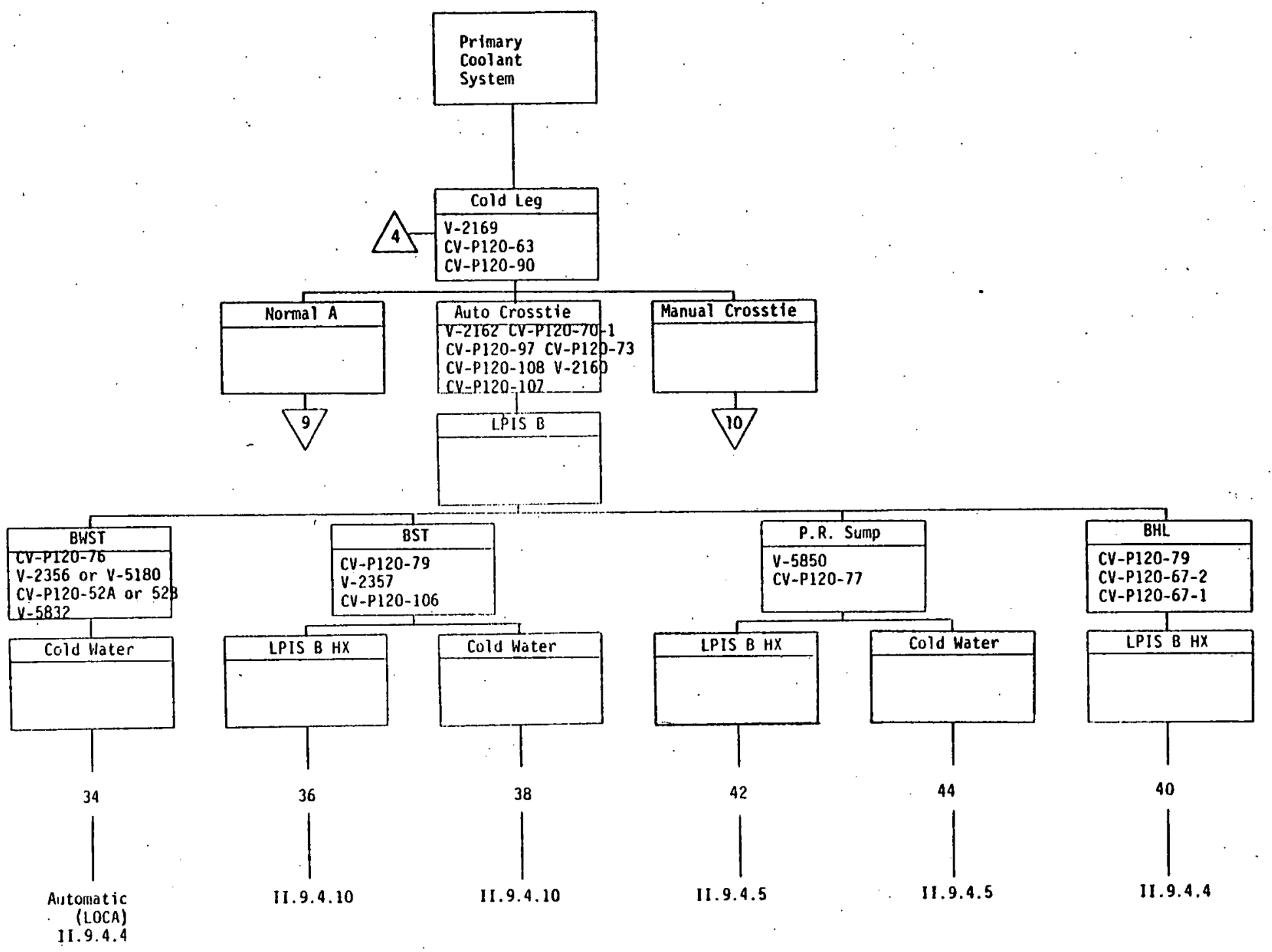


Injection

foint

Pritary

Systen



Route

Route

Pump

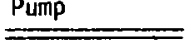

water

Source
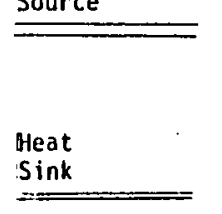

Sink

Mode

Number.

$\underline{=}$

Procedure

Number

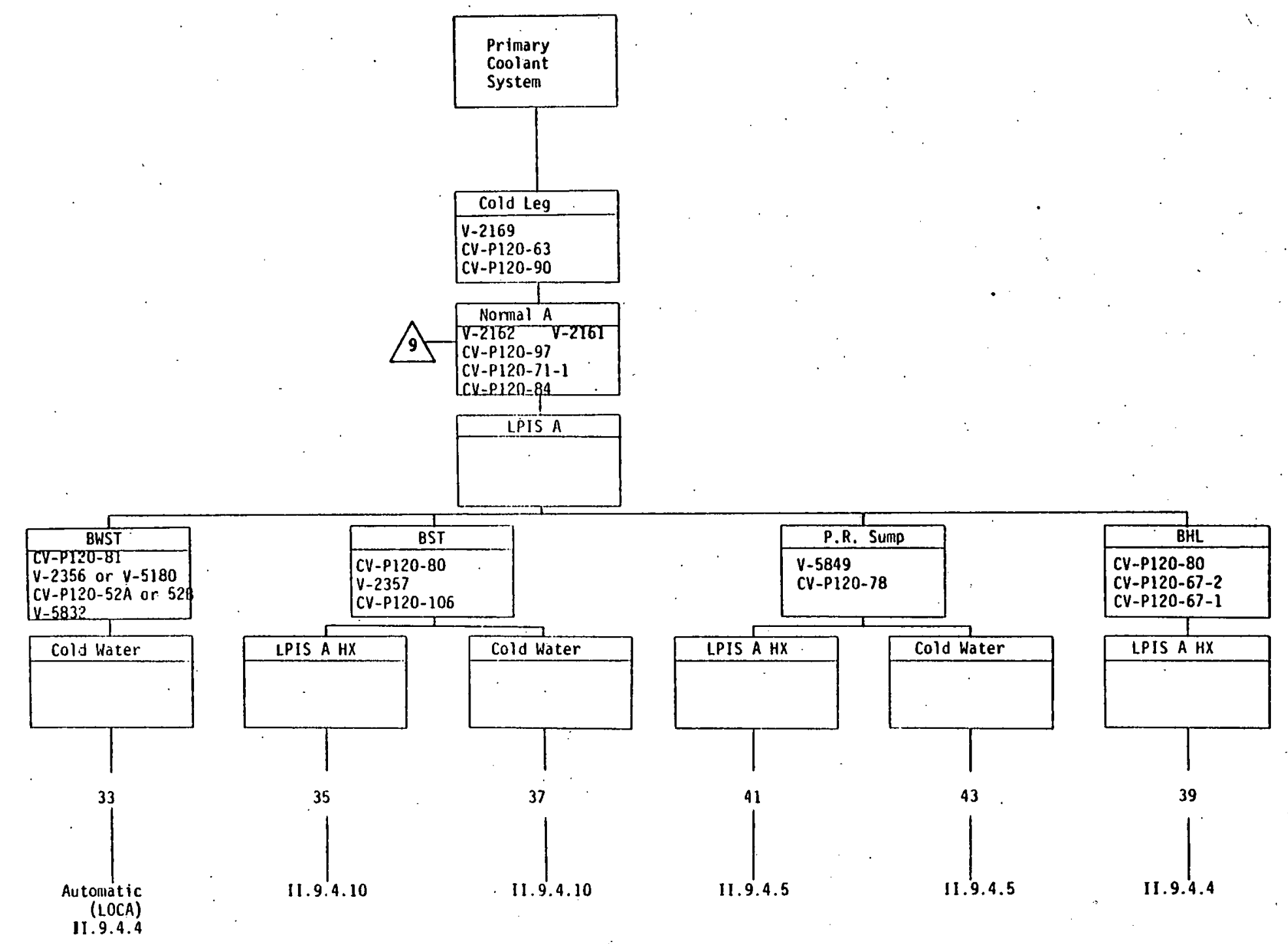


Injection

Point

Route

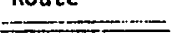

Punip

Water

Source

Source

Heat

Sink

$\underline{\underline{\text { Sink }}}$

Mode

Number



Procedure

Number

$=$

\section{Primary \\ Coolant}

System

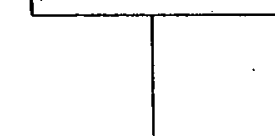

Cold Leg

CV-P120-63

CV-P120-90

Manual Crosstie

V-2162 CV-PI20-70 1

CV-P120-97 CV-P12

CV-P120-108 V-2160

CV=P120-j0
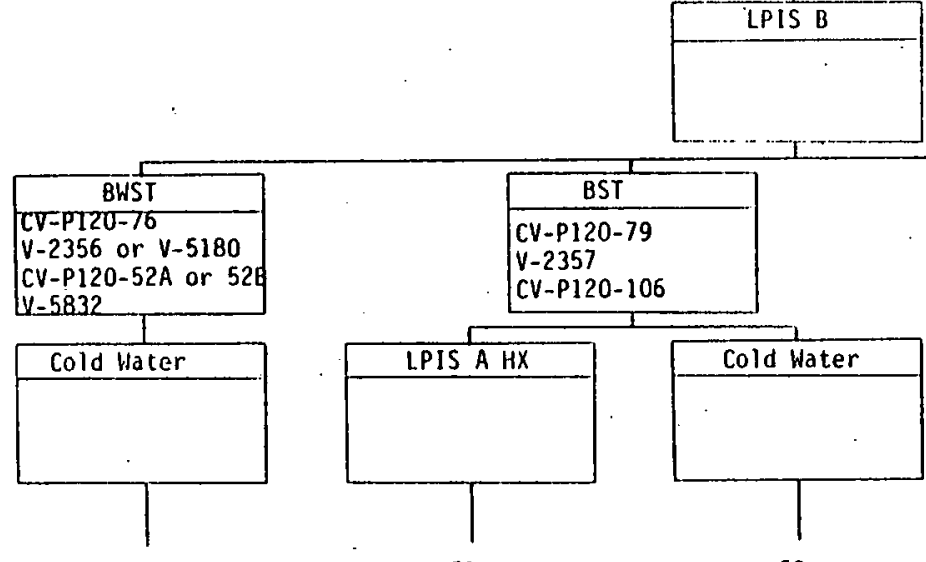

51
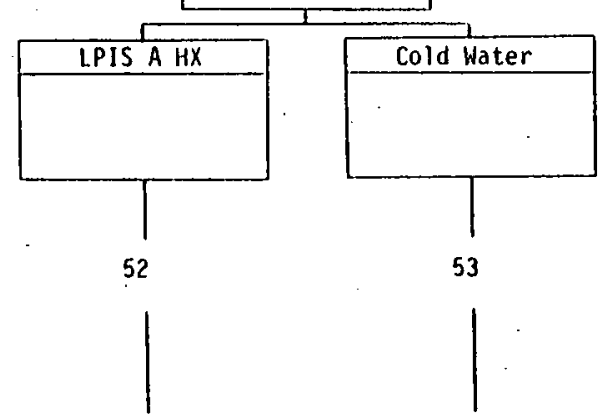

Autonatic

(LOCA)

II. 9.4 .4

II. 9.4 .10

II. 9.4 .9

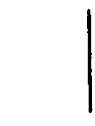

II. 9.4.10

II. 9.4 .10
II. 9.4 .9
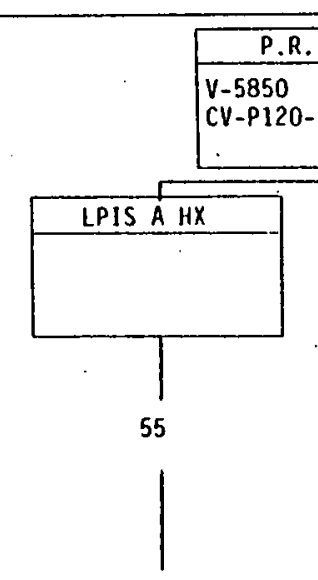

II. 9.4 .5
II. 9.4 .9

11.9 .4 .5
II. 9.4 .9

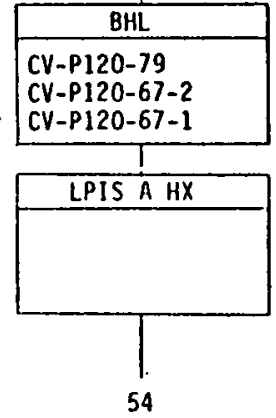

1

II.9.4.4 


\section{APPENDIX E}

COOL ING MODE INSTRUMENTATION 


\begin{tabular}{|c|c|c|c|c|c|c|c|}
\hline $\begin{array}{l}\text { Mode } \\
\text { Number }\end{array}$ & $\begin{array}{c}\text { Injection } \\
\text { Point } \\
\text { Flow }\end{array}$ & $\begin{array}{c}\text { Injection } \\
\text { Poirt } \\
\text { Pressure }\end{array}$ & $\begin{array}{l}\text { Route } \\
\text { Flow }\end{array}$ & $\begin{array}{l}\text { Route } \\
\text { Pressure }\end{array}$ & $\begin{array}{l}\text { Pump } \\
\text { Outlet } \\
\text { Flow }\end{array}$ & $\begin{array}{l}\text { Water } \\
\text { Source } \\
\text { Flow }\end{array}$ & $\begin{array}{c}\text { Water } \\
\text { Source } \\
\text { Level }\end{array}$ \\
\hline $1 A$ & $F E-P C-1$ & $P E-P C-1$ & -- & -- & -- & $F E-P C-3$ & -- \\
\hline $1 B$ & $F E-P C-1$ & $P E-P C-1$ & - & - & - & $F E-P C-3$ & -- \\
\hline ic & -- & - & FE-P4-72 & PT-P4-34 & -- & -- & $\begin{array}{l}\text { LT-P4-42 } \\
\text { LT-P4-43 }\end{array}$ \\
\hline 2 & -- & - & -- & -- & -- & - & $\begin{array}{l}\text { LI }-P 5-22 \\
\text { LI -P5-23 }\end{array}$ \\
\hline 3 & - & - & -- & -- & - & -- & $\begin{array}{l}\text { LI-P5-22 } \\
\text { LI-P5-23 }\end{array}$ \\
\hline 4 & -- & -- & -- & -- & $\begin{array}{l}\text { FI-P140-10A } \\
\text { FI-P140-10B }\end{array}$ & -- & -- \\
\hline 5 & -- & -- & - & -- & $\begin{array}{l}F I-P 140-10 A \\
F I-P 140-10 B\end{array}$ & -- & - \\
\hline$\epsilon$ & -- & $P I-P 120-61-1$ & -- & - & FI-P128- 104 & - & - \\
\hline$G B$ & -- & PI-P120-59-1 & $\ldots$ & $\therefore$ & $F I-P 128-85$ & - & LI-P120 \\
\hline
\end{tabular}




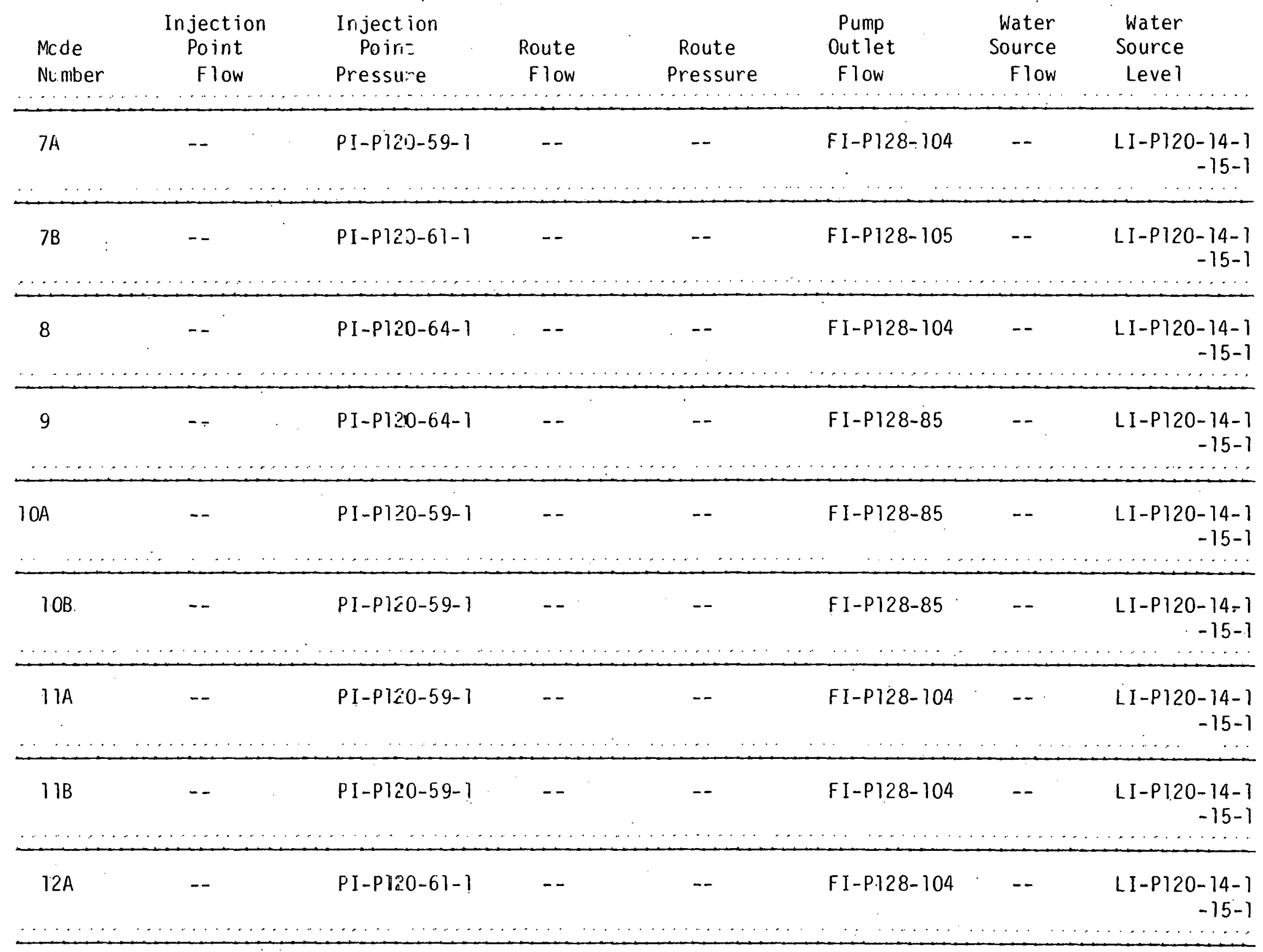




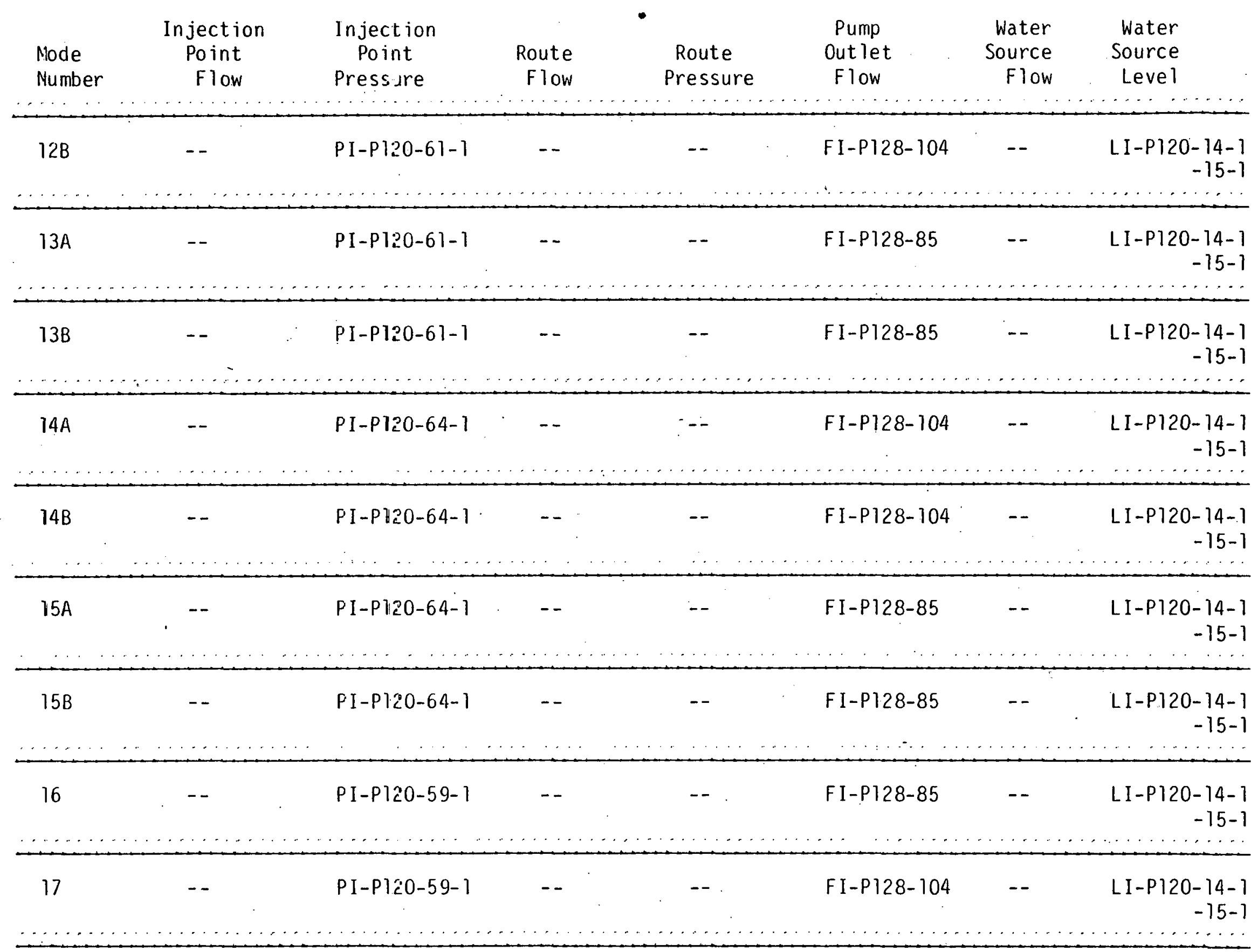




\begin{tabular}{|c|c|c|c|c|c|c|c|}
\hline $\begin{array}{l}\text { Mode } \\
\text { Number }\end{array}$ & $\begin{array}{c}\text { Injection } \\
\text { Point } \\
\text { Flow }\end{array}$ & $\begin{array}{l}\text { Injection } \\
\text { Point } \\
\text { Pressure }\end{array}$ & $\begin{array}{l}\text { Route } \\
\text { Flow }\end{array}$ & $\begin{array}{l}\text { Route } \\
\text { Pressure }\end{array}$ & $\begin{array}{l}\text { Pump } \\
\text { Outlet } \\
\text { Flow }\end{array}$ & $\begin{array}{l}\text { water } \\
\text { Source } \\
\text { Flow }\end{array}$ & $\begin{array}{c}\text { Water } \\
\text { Source } \\
\text { Level }\end{array}$ \\
\hline $20 A$ & - & PI-PI20-64-1 & $F E-P 120-36$ & - & & -- & LI-P120-87 \\
\hline $20 B$ & -- & PI-P120-59-1 & $F E-P 120-31$ & -- & & -- & LI-P120-89 \\
\hline $21 B$ & -- & PI-P120-59-1 & - & -- & $\begin{array}{c}F E-P 120-72 \\
\ldots\end{array}$ & $\begin{array}{l}-- \\
\ldots\end{array}$ & $\begin{array}{r}\text { LI }-P 120-14-1 \\
-15-1\end{array}$ \\
\hline $22 A$ & -- & PI-P120-59-1 & - & -- & FE-P120-85 & -- & $\begin{array}{r}\text { LI P120-14-1 } \\
-15-1 \\
\ldots\end{array}$ \\
\hline $22 B$ & -- & PI-PI20-64-I & - & -- & FE-P120-72 & -- & $\begin{array}{r}L I-P 120-14-1 \\
-15-1\end{array}$ \\
\hline
\end{tabular}




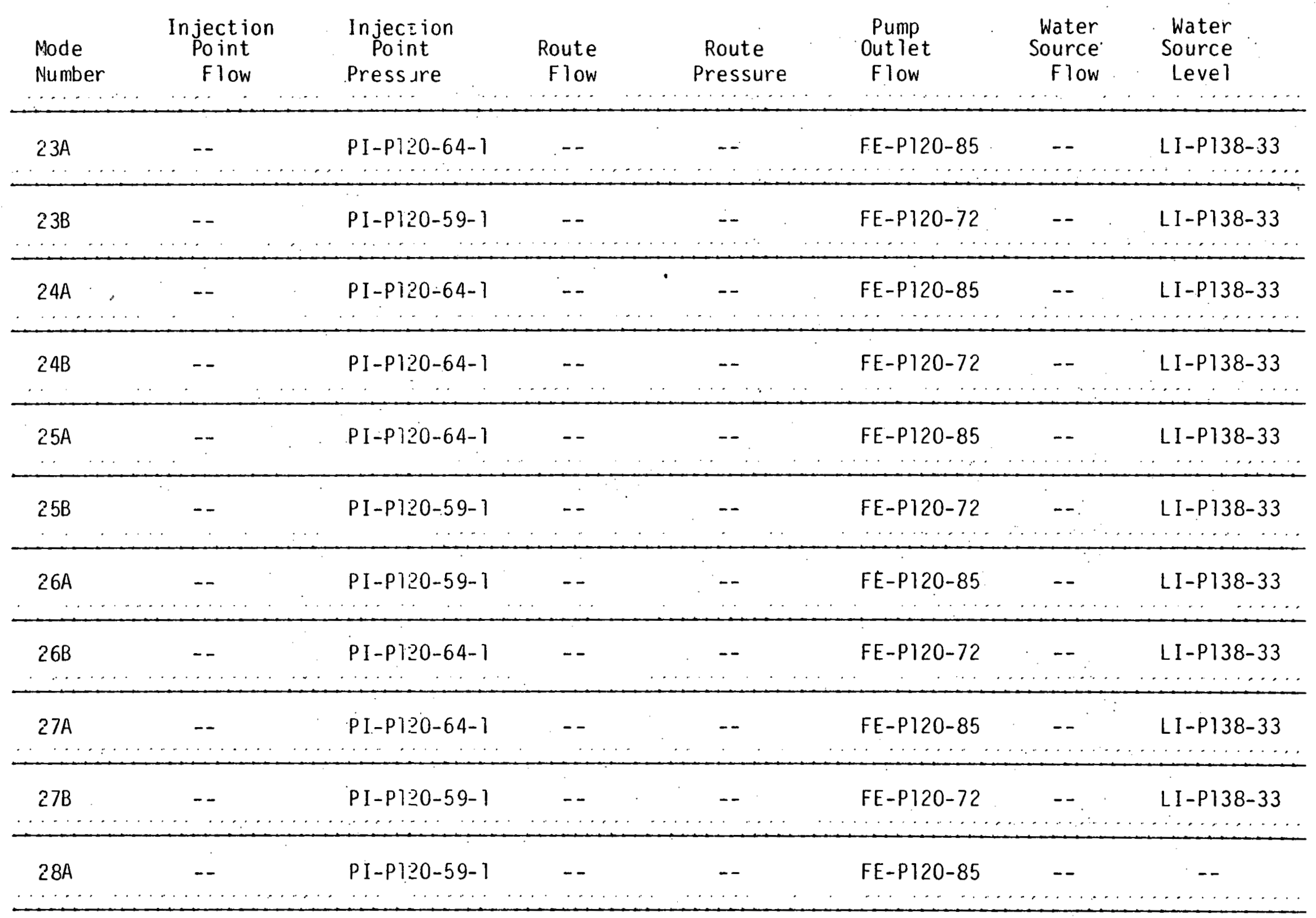




\begin{tabular}{|c|c|c|c|c|c|c|c|}
\hline $\begin{array}{l}\text { Mode } \\
\text { Number }\end{array}$ & $\begin{array}{c}\text { Injection } \\
\text { Po int } \\
\text { Flow }\end{array}$ & $\begin{array}{l}\text { Injeztion } \\
\text { Po int } \\
\text { Pressure. }\end{array}$ & $\begin{array}{l}\text { Route } \\
\text { Flow }\end{array}$ & $\begin{array}{l}\text { Route } \\
\text { Pressure }\end{array}$ & $\begin{array}{l}\text { Pump } \\
\text { Out let } \\
\text { Flow }\end{array}$ & $\begin{array}{l}\text { Water } \\
\text { Source } \\
\text { Flow }\end{array}$ & $\begin{array}{c}\text { Water } \\
\text { Source } \\
\text { Level }\end{array}$ \\
\hline $28 \mathrm{~B}$ & -- & P.I-P120-64-1 & - & -- & FE-P120-72 & -- & -- \\
\hline $29 A$ & -- & PI-P $: 20-64-1$ & -- & -- & FE-P120-85 & - & LT-P122-36 \\
\hline $29 B$ & -- & $P I-P=20-59-1$ & $\therefore$ & -- & FE-P120-72 & - & LT-P122-36 \\
\hline $30 A$ & -- & PI-P120-59-1 & -- & -- & FE-P120-85 & -- & $L T \div P 122-36$ \\
\hline $31 B$ & - & PI-P120-59-1 & - & -- & FE-P120-72 & -- & LT-P122-36 \\
\hline $32 A$ & -- & PI-P120-59-1 & -- & -- & FE-PI20-85 & -- & LT-P122-36 \\
\hline $32 B$ & -- & $P I-P I \geq 0-64-1$ & -- & - & FE-P120-72 & -- & LT-P122-36 \\
\hline 33 & -- & PI $-P I \geq 0-61-1$ & -- & -- & FE-P120-85 & -- & $\begin{array}{r}\text { LT-PI20-14-1 } \\
-15-7\end{array}$ \\
\hline
\end{tabular}




\begin{tabular}{|c|c|c|c|c|c|c|c|}
\hline $\begin{array}{l}\text { Mode } \\
\text { Number }\end{array}$ & $\begin{array}{c}\text { Injection } \\
\text { Point } \\
\text { Flow }\end{array}$ & $\begin{array}{l}\text { Injection } \\
\text { Point } \\
\text { Pressure }\end{array}$ & $\begin{array}{l}\text { Route } \\
\text { Flow }\end{array}$ & $\begin{array}{l}\text { Route } \\
\text { Pressure }\end{array}$ & $\begin{array}{l}\text { Pump } \\
\text { Out let } \\
\text { Flow }\end{array}$ & $\begin{array}{l}\text { Water } \\
\text { Source } \\
\text { Flow }\end{array}$ & $\begin{array}{c}\text { Water } \\
\text { Source } \\
\text { Level }\end{array}$ \\
\hline 35 & $\therefore-$ & $P I-P 12(1-61-1$ & -- & -- & $F E-P 120-85$ & -- & LT-P138-33 \\
\hline 36 & $\cdots$ & PI-P120-6I-1 & -- & -- & FE-P120-72 & -- & LT-P138-33 \\
\hline 37 & - & P.I-P120-61-1 & - & - & FE-P120-85 & - & LT-P138-33 \\
\hline 38 & -- & PI-P120-61-1 & -- & -- & FE-P120-72 & -- & LT-P1.38-33 \\
\hline 39 & - & $P 1-P 120-67-1$ & -- & - & FE-P120-85 & -- & LT-P138-33 \\
\hline 40 & - & PI $-P 120-61-1$ & -- & - & FE-P120-72 & -- & LT-P138-33 \\
\hline 41 & $\ldots$ & $P I-P 121]-61-1$ & -- & - & FE-P120-85 & - & $L T-P 122-36$ \\
\hline 42 & $\cdots$ & $P[-P \mid 2 i)-6]-1$ & -- & $\because$ & FE-P120-72 & - & LT-P122-36 \\
\hline 43 & - & $P I-P 12 J-61-1$ & $\because-$ & - & FE-P120-85 & - & LT-P122-36 \\
\hline 44 & - & $P I-P 12]-61-1$ & -- & $\therefore$ & FE-P120-72 & - & LT-P122-36 \\
\hline $45 A$ & -- & $P I-P 12 J-59-1$ & -- & -- & FE-P120-85 & -- & $\begin{array}{l}\text { LI }-P 120-14-1 \\
\text { LI-P120-15-1 }\end{array}$ \\
\hline
\end{tabular}




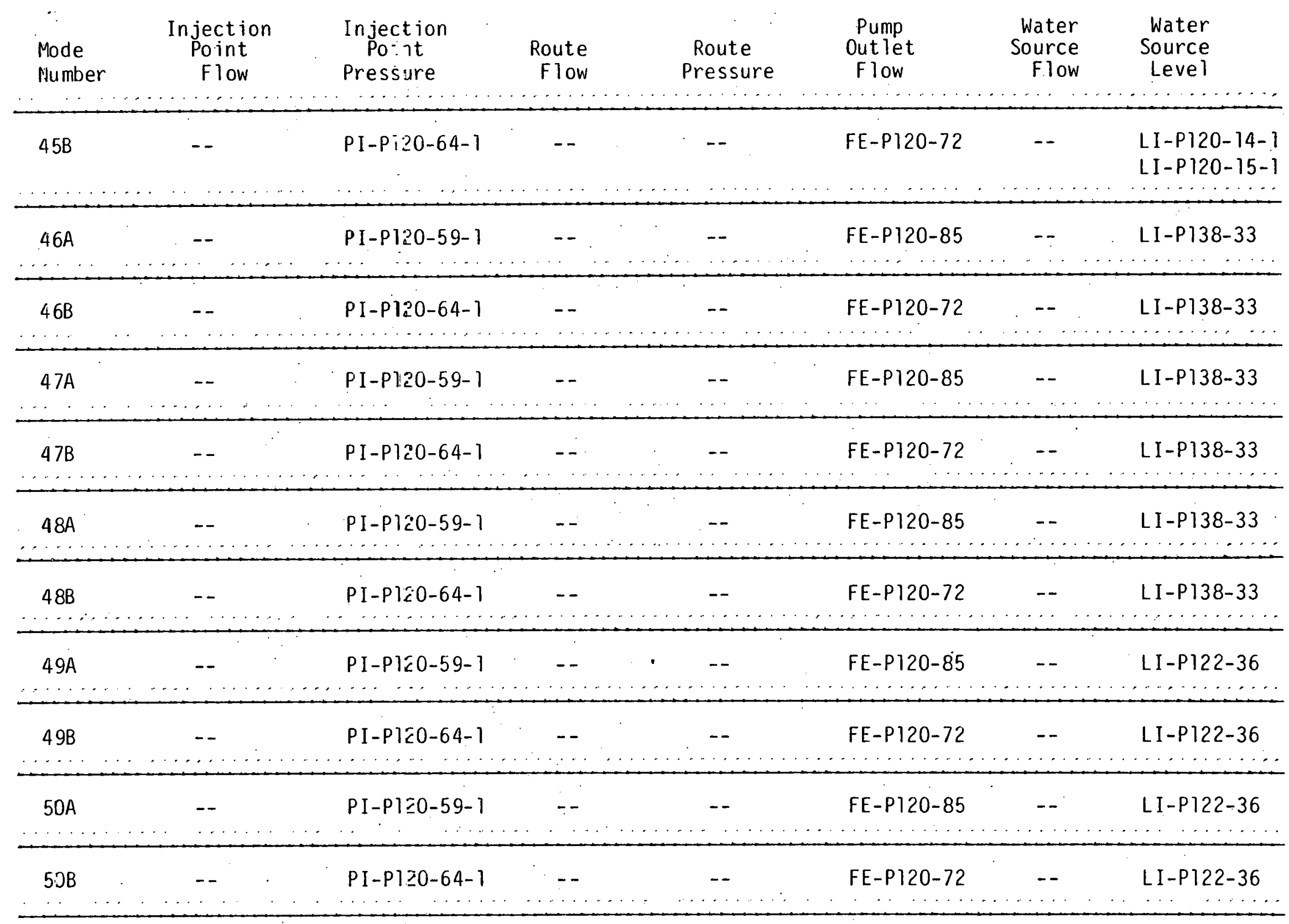




\begin{tabular}{|c|c|c|c|c|c|c|c|}
\hline $\begin{array}{l}\text { Mode } \\
\text { Number }\end{array}$ & $\begin{array}{c}\text { Injection } \\
\text { Point } \\
\text { Flow }\end{array}$ & $\begin{array}{c}\text { Injection } \\
\text { Point } \\
\text { Pressure }\end{array}$ & $\begin{array}{l}\text { Route } \\
\text { Flow }\end{array}$ & $\begin{array}{l}\text { Route } \\
\text { Pressure }\end{array}$ & $\begin{array}{l}\text { Pump } \\
\text { Outlet } \\
\text { Flow }\end{array}$ & $\begin{array}{l}\text { Water } \\
\text { Source } \\
\text { Flow }\end{array}$ & $\begin{array}{c}\text { Water } \\
\text { Source } \\
\text { Level }\end{array}$ \\
\hline 51 & - & PI $-P^{-} \geq 0-61-1$ & -- & -- & FE-P120-72 & -- & $\begin{array}{r}\text { LI-P120-14-1 } \\
-15-1\end{array}$ \\
\hline 52 & -- & PI-PI20-61-1 & - & - & FE-P120-72 & - & LI-P138-33 \\
\hline 53 & -- & $P I-P 1: 0-61-1$ & -- & -- & $F E-P 120-72$ & -- & LI - P138-33 \\
\hline$-5,4$ & - & $P I-P 120-61-1$ & - & - & FE-P120-72 & - & LI -P138-33 \\
\hline 5.5 & - & $P I-P 120-61-1$ & -- & -- & $F E-P 120-72$ & - & LI-P122-36 \\
\hline 56 & -- & PI-P\}:0-61-1 & -- & $\therefore$ & FE-P120-72 & - & $L I-P 122-36$ \\
\hline
\end{tabular}

